\title{
Tijd voor suburbia : de Amerikaanse buitenwijk in wetenschap en literatuur
}

Citation for published version (APA):

Hamers, D. A. F. (2003). Tijd voor suburbia : de Amerikaanse buitenwijk in wetenschap en literatuur. [Doctoral Thesis, Maastricht University]. Van Gennep. https://doi.org/10.26481/dis.20031106dh

Document status and date:

Published: 01/01/2003

DOI:

$10.26481 /$ dis.20031106dh

Document Version:

Publisher's PDF, also known as Version of record

\section{Please check the document version of this publication:}

- A submitted manuscript is the version of the article upon submission and before peer-review. There can be important differences between the submitted version and the official published version of record.

People interested in the research are advised to contact the author for the final version of the publication, or visit the DOI to the publisher's website.

- The final author version and the galley proof are versions of the publication after peer review.

- The final published version features the final layout of the paper including the volume, issue and page numbers.

Link to publication

\footnotetext{
General rights rights.

- You may freely distribute the URL identifying the publication in the public portal. please follow below link for the End User Agreement:

www.umlib.nl/taverne-license

Take down policy

If you believe that this document breaches copyright please contact us at:

repository@maastrichtuniversity.nl

providing details and we will investigate your claim.
}

Copyright and moral rights for the publications made accessible in the public portal are retained by the authors and/or other copyright owners and it is a condition of accessing publications that users recognise and abide by the legal requirements associated with these

- Users may download and print one copy of any publication from the public portal for the purpose of private study or research.

- You may not further distribute the material or use it for any profit-making activity or commercial gain

If the publication is distributed under the terms of Article $25 \mathrm{fa}$ of the Dutch Copyright Act, indicated by the "Taverne" license above, 
Tijd voor suburbia 



\title{
Tijd voor suburbia
}

\section{DeAmerikaanse buitenwijk in wetenschap en literatuur}

\author{
Proefschrift
}

ter verkrijging van de graad van doctor aan de Universiteit Maastricht, op gezag van de Rector Magnificus, prof.drA.C. Nieuwenhuijzen Kruseman, volgens het besluit van het College van Decanen, in het openbaar te verdedigen op donderdag 6 november 2003 om 14.00 uur

door

David Adrianus Franciscus Hamers geboren op 13 juni 1971 te Tilburg 
Promotores:

Prof.dr.ir. G.H. de Vries (Universiteit van Amsterdam)

Prof.dr. R. de Wilde

Beoordelingscommissie:

Prof.dr. J.H.W. Kusters (voorzitter)

Prof.dr. R.W. Boomkens(Rijksuniversiteit Groningen)

Prof.dr. A. Labrie

Prof.dr.G.E.E. Verstraete(Universiteit van Amsterdam)

Prof.dr. R.Zwijnenberg

Deze publicatie is mede mogelijk gemaakt dankzij financięle bijdragen van de Onderzoekschool Wetenschap, Technologie en Moderne Cultuur en de Faculteit der Cultuurwetenschappen en Capaciteitsgroep Wijsbegeerte van de Universiteit Maastricht.

2003 David Hamers / Uitgeverij Van Gennep, Nieuwezijds Voorburgwal 330, 1012 Rw Amsterdam Boekverzorging Hannie Pijnappels

Omslagfoto Marc Räder ISBN 90-5515-413-X/NUR 612 


\section{Inhoud}

Woord vooraf 9

1

Welkom in suburbia

Inleiding

1 Het Westport van de Raths 15

2 De suburbane mythe 18

3 De mythe voorbij $2 t$

4 Suburbane ruimte, tijd en identiteit 25

5 Omschrijvingen, definities, opsommingen

en geschiedenissen 28

5.1 Een wildgroei van termen 28

5.2 Omschrijvingen, definities en opsommingen 29

5.3 Geschiedenissen 32

5.4 Een inleidende geschiedenis van suburbia 34 6 De buitenwijk als inzet en uitkomst van debat 40 6.1 Sociaal-en geesteswetenschappelijke studies 40

6.2 Literaire verhalen 42

6.3 Uiteenlopende teksten als elkaars context 46

2

Het consumptieparadijs

De robuuste verbeelding van suburbia

1 Inleiding 53

2 Defifties-suburb 57

2.1 Plaats-en tijdbeeld 57

2.2 De true site of middleAmerica 58

2.3 De ideale Amerikaan 59

2.4 De nieuwe middenklasse 60

2.5 De nieuwe buitenwijk 65 
2.6 Drie in één 68

3 Vijf traditionele culturele noties 70

3.1 Het paradijs 71

3.2 De pastorale 75

3.3 Het pittoreske 79

3.4 Defrontier 80

3.5 Destad 84

4 Conclusie 89

3

In een warm bad kopje onder

De buitenwijkals strijdtoneel

1 Inleiding 95

2 Individu versus kuddedier 97

2.1 Een mislukt ontwerp 97

2.2 Een falend karakter 99

2.3 Van wetenschappelijk betogg nax literair verhaal' 105

${ }_{3}$ Passief genot of actief vormgeven? 119

3.1 Consumptie als passief genot 120

3.2 Consumptie als betekenisvolle activiteit 121

3.3 De doe-het-zelver als coproducent van suburbia 123

3.4 Decoratie als vorm van terugblikken en vooruitzien 125

4 Lot en wil 127

4.1 De middenklasse als motor van de geschiedenis 127

4.2 Geschiedenissen vol multiplex, bouwgiganten

en subsidies 130

4.3 Weg suburbia, weg middenklasse 135

4.4 Belangenverenigingen in postsuburbia 137

5 Conclusie 144

4

Bevrijd, maar benauwd

Geraffineerde kritiek in Updike's Rabbit, Run en Couples

1 Inleiding 149

2 Chronotopen in Rabbit, Run 150

2.1 Gevangenschapen ontsnapping als context 150

2.2 Het concept 'chronotoop' 154

2.3 Een appartement en een web van wegen 156 
2.4 Een sociaal circuit 158

2.5 Een verdwijnpunt 160

2.6 Een neerwaartse spiraal 161

3 Een oordeel zonder veroordeling 163

${ }_{4}$ Chronotopen in Couples 167

4.1 Paradijs, afgrond en weerhaan in het bestaan

van Piet Hanema 169

4.2 Verandering zonder vernieuwing in een kring

van paren 173

4.3 Een generatie op haar retour 176

5 Een gelaagd oordeel 180

5.1 Arme Piet 180

5.2 Mislukt escapisme 181

5.3Vreemd, maar o zo vertrouwd 185

6 Conclusie 188

5

Woestijnzand in de vooruitgangsmachine

Verhalen uit de periferie in Couplands Generation $X$

1 Inleiding 195

2 Drie bronnen, één versie van de wereld 197

3 Vier ontwikkelingen in context 201

3.1 Consumentisme, milieudegradatie en horizonvervuiling 201

3.2 Ontwrichte gezinnen 203

3.3 De verdwijning van de middenklasse 204

3.4 Neerwaartse mobiliteit 206

4 Time-out 211

5 Weg van de middenklasse 214

6 Verlangen naar toekomst 217

6.1 Een preoccupatie met tijd 218

6.2 Vertellen over tijd 219

6.3 Verlangen naar de toekomst uit het verleden 222

7 De woestijn door, naar het beloofde land 226

8 Conclusie 230 
6

Een eendagswijk

Een spel met conventies in Couplands

'Brentwood Notebook'

1 Inleiding 237

2 Brentwood bestaat niet 241

3 Brentwood bestaat, maar is onzichtbaar 243

4 Brentwood als utopie en dystopie 246

4.1 Brentwood als utopie 246

4.2 Brentwood als dystopie 250

4.3 Stilstand als ideaal en illusie 255

5 Brentwood als construct 260

6 Een portret op het kruispunt van genres 264

7 Conclusie 270

7

Tijd voor suburbia

Conclusie

1 American Beauty 275

2 Heartland en wasteland 279

2.1 Een complex stelsel 280

2.2 Continuilteit 281

2.3 Strijd 283

3 Betogen en verhalen 286

4 Een kijk op tijd 294

Noten 297

Bibliografie 331

Summary 346

Curriculum vitae 360 


\section{Woord vooraf}

Eerst woonde en werkte ik in het centrum van Maastricht, vervolgens werd ik forens. Ik verhuisde dan wel niet naar een buitenwijk, maar pendelen moest ik, tussen het Eindhovense Stratum en het historisch hart van Maastricht. Dat kost tijd, maar biedt ook ruimte om te lezen, te herlezen, te schrijven en te schrappen en bovendien om op te kijken en uit het raam te staren.

Tijdens mijn reizen passeerde ik Hoogveld, een Sittardse buitenwijk in aanbouw. Ze vertoonde verrassend veel overkomsten met het proefschrift dat ik aan het schrijven was. Eerst was er niets. Er lag een terrein open dat grensde aan van alles, maar zelf nog nauwelijks in kaart leek gebracht. Vervolgens verschenen allerlei mannetjes die aan het meten sloegen. Zij wekten de indruk deskundig te zijn, maar de eerste resultaten vielen tegen. Een weiland werd cen modderpoel. Er werd hard gewerkt, met behulp van steeds zwaardere machines, maar het geheel bood lange tijd een tamelijk chaotische aanblik. Dat veranderde toen de bouwgrond rijp was voor de eerste funderingen. Daarop werd nog geen huis neergezet, laat staan een wijk, maar muren bleven staan. Later boden ze steun aan deuren, ramen en daken. De ene woning was nog niet af of er verscheen een tweede, en zo door. Hele straten kregen vorm. Uiteindelijk verdwenen de steigers, werden gereedschappen en bouwmaterialen opgeruimd, wegen bestraat en tuintjes aangelegd. Een buurt was tot leven gekomen.

Aan een proefschrift over buitenwijken bouw je niet alleen. Graag wil ik op deze plaats en op dit moment een aantal mensen bedanken voor hun inspiratie, hulp en steun. In de eerste plaats dank ik mijn promotoren. Gerard de Vries bood me de ruimte om de grenzen tussen wetenschappelijke disciplines te onderzoeken en overschrijden. Hij gaf mij het vertrouwen dat daarvoor nodig is en wist me met zijn zowel strenge als geamuseerde blik en scherpzinnige com- 
mentaar uit te dagen en aan te moedigen telkens een stap vrder te zetten. Rein de Wilde hielp me valkuilen te omzeilen en zijpden en omwegen links te laten liggen. Als lezer, luisteraar en commentator toonde hij zich afwisselend verbaasd, sceptisch en enthusiast. Mede dankzij zijn kritische, heldere en bondige aanwijzingn won mijn betoog aan scherpte.

Ook dank ik mijn collega's van de Faculteit der Cultuurvetenschappen, in het bijzonder de leden van de capaciteitsgroeper Wijsbegeerte en Letteren \& Kunst en de onderzoeksafdeling 'Weteischap en cultuur; teksten en contexten'. Met hun belangstelling, siggesties, commentaar en aanmoedigingen zorgden zij voor een plejerige en stimulerende werkomgeving, zowel op het gebied van ondrzoek als onderwijs. Lies Wesseling wil ik bovendien bedanken voo onze gesprekken over Coupland en Ton Brouwers voor onze gedchtewisselingen over Updike en zijn voortreffelijke Engels.

Een promovendus kan daarnaast niet zonder medepromoendi. Nastdropntridiryvan aè ondèrzoekschool Wetenschap, Technologie en Moderne Cultuur - onder de bezielende leiding van Gerard de Vries, Rob Hagendijk, Barend van der Meulen, Arie Rip, Annemiek Nelis en Paul Wouters - waren de 'aio-pizza/soep'-avonden een onmisbare en erg plezierige leerschool. Hartelijk dank aan: Ruth Benschop, Marco Goud, Ruud Hendriks, Anique Hommels, Stine Jensen, Eric Lemmens, Jessica Mesman, Ruth Mourik, Peter Peters, Jessica Slijkhuis en Cécile aan de Stegge. Ruth Mourik wil ik daarnaast bedanken voor de vele autoritjes en de daarbijbehorende gesprekken, het gebabbel en die heerlijk harde muziek. Mijn kamergenotes Babette Müller-Rockstroh, Sophie Bouwens en Susan van 't Klooster wil ik bedanken voor hun aanmoedigingen in de laatste fase van mijn onderzoek, Anique Hommels voor haar bijzondere gezelschap en onze discussies over stad en buitenwijk in de jaren daarvoor. Peter Peters was onze vaste gast. Als hij in 'zijn' stoel ging zitten, kwam hij iets vertellen dat de pauze meer dan waard was.

Dan zijn er nog Ivo, Ilse, John, Claudia, Hans, Marcia, Micha, Vivian, Niels en Sieta - vrienden en vriendinnen die mij enthousiast, met veel humor en relativerende woorden, hebben geïnspireerd. In het bijzonder bedank ik Karin, voor de rust die zij uitstraalt, en Henk, voor zijn kritische blik en zorgvuldige lezing van eerdere versies van dit boek. 
Brigit, Ralf, Hugo, Myrthe, Guy, Marion, Geert, Cor en Miel wil ik bedanken omdat het aan hen zo gemakkelijk is uit te leggen wat mij toch al die jaren bezighield. Vincent en Esther bedank ik voor al die vrijdagavonden vol zin en onzin, mijn ouders voor alles wat ze me meegaven, hun enorme betrokkenheid en onvoorwaardelijke steun.

Tot slot wil ik Hanneke bedanken, omdat ze niet alleen in ons huisje in de Bosranklaan, in de bergen en de woestijn, op eilanden, in wereldsteden en buitenwijken, maar altijd en overal heel dicht bij me is. 

Welkom in suburbia

\author{
Inleiding
}





\section{Het Westport van de Raths}

Op een avond in juni 1953 komt Tom Rath met de trein uit New York City aan in zijn woonplaats Westport, Connecticut. Te midden van een grote groep mannen die net als hij van hun werk komen, kijkt Tom naar de plaats waar zijn vrouw Betsy op hem wacht. Ook deze avond is ze op tijd. Ze zwaait en lacht hem stralend toe. 'Hil' begroet Tom haar. 'It's good to get home'(Wilson(1956): p.7).

Tom, het hoofdpersonage uit Sloan Wilsons roman The Man in the Grey Flannel Suit (1955) ${ }^{1}$, is een drieëndertigjarige forens die dagelijks heen en weer pendelt tussen zijn woning in de buitenwijk en een kantoor in de stad. Betsy doet het huishouden en ontfermt zich over hun drie kleine kinderen. Vergeleken met het arme en vervallen Harlem dat Tom op weg naar zijn werk passeert, is het aan Greentree Avenue in Westport goed wonen. Vergeleken met de upper class in het nabijgelegen landelijke, riante South Bay, wonen de Raths bescheiden. Maar hun huis aan Greentree Avenue is meer dan een plek tussen de volle, vuile stad en het mooie, ruime platteland. Het drukt herinneringen en verwachtingen uit en staat voor een hang naar zekerheid en een verlangen naar vooruitgang. Betsy laat weten dat sommige bewoners in hun straat tevreden zijn. Zij zijn blij met wat ze hebben bereikt. Ook zij en Tom mogen eigenlijk niet klagen, vindt ze. Tegelijkertijd weet ze maar al te goed dat ze na zeven jaar Greentree Avenue méér wil. Hun huis is vooral een opstapje naar ruimer, mooier en comfortabeler wonen. Vrijwel niemand, weet Betsy, beschouwt de bescheiden, vrijwel identieke huizen in hun straat als eindhalte. Een straat als de hunne is een plaats waar jonge gezinnen wachten tot ze zich iets beters kunnen veroorloven. Wie salarisverhoging krijgt, organiseert een cocktailparty om het met de buren te vieren. Wie een groter huis kan kopen, geeft een moving-out party. Tijdens zo'n feestje kunnen buren elkaar verzekeren dat Greentree Avenue ook voor hen niet meer is dan'a step- 
ping stone to the same kind of life on a bigger scale' (ibid: p. 121). Grootse plannen zullen in dit gezelschap dromen blijven, mogelijkheden om een vertrouwd leven te leiden in een groter huis en een mooiere omgeving zal het met beide handen aangrijpen.

Zo beschouwd, staat het leven in Westport niet alleen voor een bestaan op een bepaalde plek, maar brengt het ook een bepaalde orientatie in de tijd tot uitdrukking. In deze suburbane gemeenschap gaat rust gepaard met onrust. Sommige bewoners zijn tevreden met de bereikte status-quo, andere ambiëren en verwachten verbetering. Het huis van de eersten symboliseert een gerealiseerde positie op de sociaal-economische ladder, dat van de laatsten is een teken van het verlangen een tree hoger te stijgen. Beide oriêntaties kenmerken het echtpaar Rath. Betsy is niet bang een kans om iets nieuws van de grond te krijgen aan te grijpen. Zij kijkt vol vertrouwen vooruit, durft besluiten te nemen en toont de daadkracht die nodig is om plannen te realiseren. Tom is minder zelfverzekerd. Zijn ervaringen als soldaat in de Tweede Wereldoorlog hebben zijn zelfvertrouwen geschaad. Een groter huis en een nieuwe auto zouden welkom zijn, maar niet ten koste van een goede levensverzekering en spaargeld op de bank. Wat Betsy angstig noemt, vindt Tom verstandig en waar Betsy gecalculeerde risico's durft te nemen, wil Tom eerst veiligstellen wat is bereikt. De moedige $G r$ uit de oorlog is een ander mens dan de voorzichtige forens van nu. 'T'm just a man in a grey flannel suit,' denkt hij. 'I must keep my suit neatly pressed like anyone else, for I am a very respectable young man' (ibid: p. 109).

Het verhaal van de Raths, zo wordt Wilsons roman ingeleid, is exemplarisch voor het leven van duizenden gezinnen in het suburbia van de Noord-Amerikaanse middenklasse in de jaren vijftig. ${ }^{2}$ In die hoedanigheid wordt het ook opgevoerd in twee van de invloedrijkste kritisch-sociologische teksten uit de periode waarin Wilsons roman verschijnt, William $H$. Whyte's The Organization Man (1956) en David Riesmans 'The Suburban Dislocation' 3 (1957). In beide geldt Tom als vertegenwoordiger van een goed opgeleide middenklasse die in de stad in grote bedrijven kantoorfuncties vervult om daarmee een bestaan in de buitenwijk te bekostigen. Waar het Tom en de zijnen om gaat, is een gezinsleven te midden van gelijkgezinden in een comfortabele en overzichtelijke suburb. Toch bepaalt niet alleen 
'suburban domesticity and peace', zoals Riesman het uitdrukt (Riesman (1957): p. 131), de sfeer. Doordat in deze gemeenschap status van bijzonder belang is, heerst er tussen de gelijkgezinden een bepaalde spanning. Wie zich bijvoorbeeld een nieuwe auto kan veroorloven, laat niet na deze zo zichtbaar mogelijk voor het huis te parkeren. En geldt deze wagen eenmaal als de nieuwe norm, dan zullen de buren snel een eigen exemplaar aanschaffen. Wie, met andere woorden, zijn positie kan verbeteren, doet dat. Wie de buurman zijn positic ziet verbeteren, volgt zo snel mogelijk.

Greentree Avenue, Tom in zijn grijze flanellen pak en Betsy die het gezinsleven op orde houdt, staan voor een beeld van het suburbia uit de jaren vijftig dat volgens socioloog Mark Baldassare in Amerika's collectieve geheugen staat gegrift. Het belichaamt niet alleen wat het grote publiek zich bij de buitenwijk voorstelt, schrijft hij in Trouble in Paradise (1986), het wordt ook opgevoerd in veel klassieke wetenschappelijke studies naar suburbia. In tegenstelling tot de indruk die Whyte en Riesman wekken, typeert Baldassare het als een inaccuraat beeld. De buitenwijk als een veilig, stabiel en comfortabel woonoord waar gezinnen uit de blanke middenklasse een eigen, vrijstaande woning bezitten, waar de vrouwen zich wijden aan taken in en rond het huis en de mannen's avonds thuiskomen van hun werk in de stad, is een stereotype, concludeert hij. ${ }^{4}$ 


\section{De suburbane mythe}

Baldassare is geenszins de enige die het hierboven geschetste beeld van de buitenwijk een stereotype noemt. We zouden zelfs kı ${ }^{\text {nnen }}$ spreken van een traditie waarin wordt gestreden tegen de eenzijdige verbeelding van suburbia. Hoewel het vaak opduikt, is niet 'het stereotype' in die traditie het centrale begrip, maar de zngennemde subuibane mythe. Met deze mythe doelen onder anderen sociologen en stadshistorici sinds ruim veertig jaar op de in hun ogen eenzijdige en bovendien veelal negatieve verbeelding van de Amerikaanse buitenwijk en haar middenklassebewoners die in de tweede helft van de twintigste eeuw het aanvankelijk voornamelijk enthousiaste onthaal van suburbia is gaan overschaduwen.

Een van de eerste goed uitgewerkte aanvallen op de suburbane mythe is die van socioloog Bennett Berger. Zowel in zijn WorkingClass Suburb (1960) als in de essays 'The Myth of Suburbia' en 'Suburbs, Subcultures, and Styles of Life' uit de bundel Looking for Ameri$c a(1971)^{5}$ bestrijdt hij de suggestie dat de buitenwijk in de loop van de jaren vijftig een nieuwe, bijzondere levensstijl zou hebben voortgebracht. Dat er sprake is van een grote trek naar de stedelijke periferie staat buiten kijf, stelt Berger. Maar dat het suburbane leven een sociale en culturele revolutie zou inhouden, dat het een unieke levenswijze of, zoals sommige sociologen in die jaren beweren, een new social character of een new American voortbrengt, kunnen we volgens hem onmogelijk een feit noemen. Berger spreekt van een mythe waarin een beeld wordt geschetst van vrijwel identieke huizen met nette gazonnetjes aan bochtige wegen, van jonge gezinnen waarin goed opgeleide mannen als ingenieur, verkoper, onderwijzer of verzekeringsagent een veelbelovende carrière in het vooruitzicht hebben en eveneens goed opgeleide vrouwen op basis van de nieuwste theorieën de kinderen opvoeden, van een hyperactief gemeenschapsleven en overmatige onderlinge bemoeienis en van een 
al te homogene gemeenschap en cen al te grote neiging tot conformisme (zie Berger (1971a): p. 152). Zowel populaire media als wetenschappelijke studies, concludeert Berger, worden gedomineerd door deze 'full-blown myth, complete with its articles of faith, its sacred symbols, its rituals, its promise for the future, and its resolution of ultimate questions'(ibid: pp. 151-2).

De meeste van de latere aanvallen op deze suburbane mythe zijn te beschouwen als variaties op de thema's die Berger aansnijdt. Na een verkorte versie van Bergers schets verdedigt socioloog Herbert Gans bijvoorbeeld in People and Plans (1968) de buitenwijk tegen beschuldigingen van 'ennui and malaise which result in excessive drinking, adultery, divorce, and mental illness' (Gans(1968): p. 137). ${ }^{6}$ Even kritisch, maar veel venijniger, analyseert Scott Donaldson in The Suburban Myth (1969) de wijzen waarop suburbia de rol van slechterik krijgt toebedeeld in wat hij het 'ruraal-urbane melodrama' noemt. ${ }^{7}$ Donaldson richt zich daarbij niet alleen op aanvallen uit onderzoeksdisciplines als sociologie, psychologie en geschiedenis, maar evenzeer op architectuurkritiek, politiek commentaar en de verbeelding in literaire fictie. Met betrekking tot deze laatste wijst hij onder andere op David Karps roman Leave Me Alone (1957) en Richard Yates' Revolutionary Road (1961), waarin suburbanisanten op verschillende wijzen te kijk worden gezet. Het meest windt hij zich op over John Keats, die zich in zijn cynische The Crack in the Picture Window (1956) tegelijk 'more explicit and less thoughtful' toont dan andere critici. Een auteur die zijn hoofdpersonages John en Mary Drone noemt, haalt Donaldson uit, blinkt in elk geval niet uit in subtiliteit (zie Donaldson (1969): pp. 7, 8). De wijze waarop de mythe in populaire cultuur gestalte krijgt, komt onder andere aan bod in Stephanie Coontz' The Way We Never Were (1992). Coontz wijst bijvoorbeeld op de invloed van de immens populaire sitcoms uit de jaren vijftig op de beeldvorming omtrent het 'normale' suburbane middenklassegezin. Zelfs in de politiek, schrijft ze, wordt tot op de dag van vandaag gesproken in termen van het Leave it to Beaver-en Ozzie and Harriet-model (zie Coontz (1992): p. 23). ${ }^{8}$ Amerikanisten Rosalyn Baxandall en Elizabeth Ewen, om een laatste, recent voorbeeld te noemen, beginnen hun Picture Windows (2000) met het onderkennen van hun eigen 'antisuburban snobbery'. Ook zij hadden het beeld van de boring burbs voor ogen toen ze aan hun onder- 
zoek begonnen. In hun boek proberen ze een indruk te geven van het suburbia dat schuilgaat achter wat zij omschrijven als een mythische façade (zie Baxandall en Ewen (2000): pp. xvi, xviii).

De suburban myth of the myth of suburbia, is de gedachte, heerst niet alleen in magazines, televisieseries en films, maar evenzeer in sociaal- en geesteswetenschappelijke studies en literaire fictie. Met name in deze laatste twee tradities kan een hardnekkige, eenzijdige en overwegend negatieve representatie opmerkelijk worden genoemd. In zowel wetenschappelijke studies als literair werk verwachten we doorgaans een verfijnder verbeelding aan te treffen. In de hierboven genoemde studies wordt, impliciet dan wel expliciet, gepleit voor een dergelijke verbeelding van de buitenwijk en haar bewoners. In dit proefschrift staan belangrijke vooronderstellingen van dat pleidooi ter discussie. Wordt de mythe niet al te eenvoudig voorgesteld? Steekt ze niet veel complexer in elkaar en vormt ze niet juist daardoor zo'n robuuste verbeelding van suburbia? $\mathrm{En}$ is deze hardnekkige representatie wel zo dominant? Is er niet veel meer variatie dan wel wordt gedacht? Is het bovendien überhaupt zinvol te denken in termen van een mythe? Helpt het onderscheid tussen mythe en realiteit dat eraan ten grondslag ligt ons wel subtieler beelden van de buitenwijk op het spoor te komen? 


\section{De mythe voorbij}

De laatste jaren groeit de kritiek op het intellectuele dédain waarmee al decennialang over de suburb en haar bewoners wordt geschreven. Sinds enige tijd woont de meerderheid van de Amerikanen in de buitenwijk. Bovendien is een steeds groter deel daarvan er ook aan het werk. 'Suburbia,' zo leidt historicus Kenneth Jackson zijn invloedrijke Crabgrass Frontier (1985) in, 'has become the quintessential physical achievement of the United States' (Jackson (1987): p. 4). Bovendien, voegt hij toe, belichaamt het meer nog dan grote auto's en hoge gebouwen de hedendaagse Amerikaanse cultuur. De gedachte is dat deze omgeving genuanceerd dient te worden verbeeld. Niet alleen omdat we graag over een subtiel beeld van de buitenwijk beschikken - zoals er een rijkgeschakeerd beeld bestaat van de stad -, maar ook omdat de verbeelding van suburbia haar sporen nalaat in de suburbane werkelijkheid. Zo licht Berger zijn aanval op de mythe toe door te wijzen op haar performativiteit. 'Once myths gain currency,' schrijft hij, 'once they go, as we say, "into the cultural air", they become real' (Berger (1971b): p. 184). Dat een bepaald beeld de werkelijkheid geweld aandoet, doet aan de werkzaamheid in de praktijk niets af: 'if a situation is defined as real,' betoogt Berger, 'it is real in its consequences' (ibid). ${ }^{9}$ De wijze waarop suburbia wordt verbeeld, beïnvloedt zowel de gebouwde omgeving als degenen die daarin wonen en werken. Ze komt tot uitdrukking in keuzen te investeren in binnensteden of juist stadsranden, beleidsplannen voor de ligging en inrichting van nieuwe buitenwijken, de vormgeving van woningen en de keuze van mensen om daarin wel of niet te gaan wonen.

Een aanval op de dominantie van de suburbane mythe is daarmee meer dan een poging om in andere termen over de buitenwijk na te denken. Zo'n aanval heeft ook tot doel te vermijden dat de mythe een richtsnoer wordt voor het handelen. Dat geldt natuurlijk 
niet alleen in de Verenigde Staten, maar evenzeer in het suburbaniserende Nederland. Ook in ons land ontstaan plannen voor ruimtelijke ordening in een cultuur die een traditie kent van minachting voor buitenwijken. ${ }^{10}$ Niet alleen die uit de jaren zeventig en tachtig moeten het ontgelden, ook de nieuwe Vinex-locaties hebben al voordat ze zijn gerealiseerd een uitermate slechte reputatie. Bekend is wellicht de typering 'diarree van doorzonwoningen' van PvdA-politicus Rick van der Ploeg, minder bekend misschien een anekdote over een vakantie van zijn nog kritischer partijgenoot en oud-directeur van het Nederlands Architectuurinstituut Adri Duivesteijn. Elke ochtend bezocht hij met zijn kinderen een Vinex-wijk, elke middag, zo gaat het verhaal, deden ze iets leuks. Of deze(sub)urban legend deel uitmaakt van een full-blown myth valt te bezien, hardnekkig is de veroordeling van het suburbane bestaan ook in Nederland in elk geval wel.

Naast het streven naar een subtiele verbeelding van de buitenwijk wordt dit proefschrift gemotiveerd door een streven naar een nieuwe wijze van nadenken over die verbeelding. Tegenover het denken in termen van de mythe waarmee de dominante representatie van suburbia traditioneel te lijf wordt gegaan, wil ik een nieuwe wijze van redeneren stellen. Om een aantal redenen neem ik afstand van het repertoire van de mythe.

De eerste heeft te maken met het verschil tussen afbeelding en verbeelding. In een repertoire waarin een bepaalde representatie van suburbia wordt angemerkt als 'suburbane mythe' staat de vraag centraal of het beeld van een buitenwijk wel overeenstemt met die buitenwijk in werkelijkheid. We kunnen spreken van een realistisch repertoire waarin de inzet een getrouwe afbeelding van het feitelijke suburbia is. Het streven is een accurate weergave van de veelvormige, complexe en dynamische suburbane realiteit, zoals bijvoorbeeld Gans, Baldassare en Coontz bepleiten. ${ }^{11}$ In dit streven moet de mythe het ontgelden, omdat ze die realiteit vertekent. ${ }^{12} \mathrm{Ze}$ dient het veld te ruimen voor realistischer representaties van de buitenwijk.

Dat op deze wijze de mythe niet eenvoudig aan het wankelen wordt gebracht, blijkt uit het feit dat ze tot op de dag van vandaag wordt aangevallen, terwijl ze al sinds de jaren vijftig onder vuur ligt. Mythen worden zelden ontkracht door empirisch onderzoek, 
waarschuwde Berger al, 'they have going for them something considerably more powerful than mere evidence' (ibid: p. 171). Later wijst ook Gans op de veerkracht van de suburbane mythe, evenals David Thorns, die in Suburbia (1972) constateert dat de mythe ondanks correcties in een hele reeks sociologische studies nog steeds springlevend is (zie Gans (1968): p. 137) en Thorns (1972): p. 148).

Het blijkt niet eenvoudig om met realistisch vlagvertoon representaties gestalte te geven die kunnen concurreren met de suburbane mythe. In dit proefschrift kies ik daarom een andere benadering. Dat er een verbeelding bestaat waarin steeds weer dezelfde aspecten van de buitenwijk worden opgevoerd en waarin deze bovendien vaak uitgesproken negatief worden gewaardeerd, stel ik hier niet ter discussie. Teksten waarin deze hardnekkige representatie gestalte krijgt, wil ik echter niet opvatten als de tegenpool van teksten waarin de buitenwijk accuraat zou worden afgebeeld. Niet de oppositie 'mythisch - realistisch' is het uitgangspunt, maar de gedachte dat buitenwijken in alle teksten constructies zijn. Ik beschouw een beeld van een suburb en haar bewoners niet eenvoudig als een afbeelding van een suburbane werkelijkheid, maar vooral als een resultaat van de wijze waarop het in de tekst gestalte krijgt. We dienen ons af te vragen wat er in een tekst gebeurt waardoor juist dit en niet een ander beeld tot stand komt. De werkelijkheid wordt daarin namelijk niet zomaar beschreven, er wordt van alles gemobiliseerd om ons die werkelijkheid op een bepaalde manier te laten denken. ${ }^{13}$ Welke thema's, motieven en vertelstructuren dragen bij aan de totstandkoming van een bepaalde verbeelding? Is de buitenwijk wel het 'eigenlijke' onderwerp, of staat ze wellicht symbool voor iets anders, bijvoorbeeld voor een bepaalde levensstijl? Welke culturele ideeën en verhalen worden gemobiliseerd om dit beeld te maken tot wat het is? Wie komt aan het woord en wiens blik bepaalt wat we te zien krijgen?

Om dergelijke vragen te kunnen beantwoorden, staat niet de vergelijking van een afbeelding met de werkelijkheid centraal, maar een confrontatie van uiteenlopende, zowel wetenschappelijke als literaire teksten waarin buitenwijken op verschillende wijzen worden verbeeld. ${ }^{14}$ Uit deze confrontatie - waarin grenzen tussen zowel onderzoeksdisciplines onderling als die tussen wetenschap en literatuur worden overschreden - blijkt een veel grotere variatic 
aan verschijningsvormen van de buitenwijk en haar inwoners dan vaak wordt aangenomen. Uitgangspunt daarbij is dat we niet in het algemeen kunnen stellen dat in een bepaald soort teksten een eenzijdige verbeelding tot stand komt, terwijl in een ander suburbia in verfijnder gestalten verschijnt. Steeds zullen we specifieke gedaanten moeten vergelijken.

Een bijkomende reden om me niet te bedienen van het repertoire van de mythe is dat het onterecht suggereert dat de mythe een eenvoudig beeld inhoudt, terwijl andere beelden complexer zouden zijn. ${ }^{15}$ Ook de mythe is een gelaagd geheel. In Bergers omschrijving, bijvoorbeeld, gaat het niet slechts om monotone bebouwing, maar evenzeer om een bepaalde sociale interactie tussen buurtgenoten, ideeěn over de opvoeding van kinderen en de toekomstverwachtingen van kantoorklerken. Evenzo staan in het beeld van Westport in The Man in the Grey Flannel Suit niet slechts bescheiden huizen centraal, maar bovenal ook de spanning tussen tevredenheid en aspiraties die tijdens moving-out parties tot uiting komt. Naast opvattingen over de inrichting van de suburbane ruimte krijgen verlangens en angsten ten aanzien van sociale mobiliteit en status uitdrukking.

Een laatste reden hangt hiermee nauw samen. Een van de belangrijkste ontwikkelingen in de verbeelding van suburbia, zo betoog ik in dit proefschrift, is dat het beeld van de buitenwijk in de loop van de jaren vijftig samensmelt met dat van de middenklasse. Verbeelding van de één is in veruit de meeste gevallen verbeelding van de ander. Denken in termen van een mythe verblindt ons in dit opzicht: we krijgen geen zicht op hoe deze constructie precies in elkaar steekt en hoe andere, misschien verrassende beelden erop variëren. Zoals ik hierboven met betrekking tot Bergers beeld en het Westport van de Raths aangaf, is die constructie niet alleen een kwestie van ruimtelijke ordening, maar evenzeer van een levensstijl waaruit een bepaald perspectief op tijd spreekt. Met name de wijze waarop levenswijze en tijdperspectief worden opgevoerd, draagt eraan bij dat sommige beelden van suburbia hardnekkig standhouden. Beelden die daarop willen variëren, dienen daarom niet alleen een bepaalde ruimte neer te zetten, maar moeten bovenal een concurrerend beeld schetsen van tijd. Het credo in dit boek is dus niet zozeer 'ruimte voor de buitenwijk', als wel 'tijd voor suburbia'. 
Suburbane ruimte, tijd en identiteit

Het is niet verwonderlijk dat de buitenwijk primair wordt opgevat als een ruimte. Ze wordt beschouwd als een plaats met een bepaalde ligging, bijvoorbeeld aan de rand van een stad, ergens tussen die stad en het platteland of juist in een gebied dat door een groeiende metropool dreigt te worden opgeslokt. Vaak gaat de aandacht uit naar de functies van de suburbane ruimte, bijvoorbeeld als woonomgeving of recreatiegebied en, recenter, als locatie voor de productie van goederen en het aanbod van diensten. Daarnaast komt meestal de inrichting van de ruimte aan bod. Waar lopen wegen bijvoorbeeld, hoe groot zijn percelen, zijn wijken vrij toegankelijk of worden ze juist van hun omgeving afgeschermd? Bovendien wordt vaak aan de orde gesteld hoe de ruimte en wat zich daarin bevindt, is vormgegeven. Hoe zien parken eruit, in welke stijl zijn woningen opgetrokken, welk type auto staat op de oprit?

De ruimte wordt vaak in relatie gebracht met wat wel een suburbane levensstijl wordt genoemd. We dienen suburbia niet alleen op te vatten als 'an emergent architectural space', schrijft Roger Silverstone bijvoorbeeld in zijn inleiding van de bundel Visions of Suburbia (1997), maar evenzeer als 'a set of values and a way of life' (Silverstone (1997): p.3). ${ }^{16}$ Of we kunnen spreken van zo'n specifiek suburbane levenswijze of van een suburbane identiteit is al decennialang onderwerp van discussie. Dat neemt niet weg dat vaak verbanden worden gelegd tussen het karakter van de suburbane ruimte en de aard van het bestaan daarin. Zo wordt suburbia opgevoerd als de plaats waar ruime huizen een comfortabel leven mogelijk maken en waar groen het gezin tot rust brengt, of juist als de plek waar een gebrek aan culturele instellingen verveling oplevert en waar zogenoemde zoning-regels bepaalde sociaal-economische en etnische groepen buitensluiten. Hoe dan ook, deze ruimtelijke interpretatie levert beelden op waarin de gebouwde omgeving wordt gelezen als 
een uitdrukking van het gedachtegoed en de levensstijl van bewoners.

Hoezeer in deze representatie het primaat ook ligt bij de ruimte, steeds krijgt met die ruimte een bepaalde tijd gestalte. En wat geldt voor de ruimte, gaat op voor de tijd, namelijk dat een verband wordt gelegd tussen die tijd en de leefwijze en identiteit van de suburbanisant. Voor zover dat expliciet gebeurt, betreft het meestal tijd opgevat als een instrument van sociale organisatie en coördinatie. Daarbij zijn voornamelijk kwesties als de dagindeling van forenzen en huisvrouwen en de weekindeling in werkdagen en weekend belangrijk. ${ }^{17}$ De verhouding tussen de tijd waarin wordt gewerkt en de tijd voor gezin, rust en ontspanning wordt cruciaal geacht voor het bestaan van de buitenwijkbewoner. Veel implicieter krijgen relaties gestalte tussen dat bestaan en wat ik de temporele orièntatie zal noemen. Halen we ons Greentree Avenue nog eens voor de geest, dan zien we de Raths niet alleen wonen in een vrijstaand huis in een schone en veilige slaapstad, maar vooral ook omgaan met de spanning tussen Toms behoudzucht en Betsy's verlangen in de toekomst hun positie te verbeteren. De wijzen waarop het suburbane bestaan met dergelijke oriëntaties in de tijd in verband wordt gebracht, staan in dit proefschrift centraal.

Onder temporele oriëntatie versta ik niet de subjectieve, psychische ervaring van het tijdverloop zoals die bijvoorbeeld in de filosofie door fenomenologen is bestudeerd of zoals die in de psychologie onder de noemer tijdbeleving is onderzocht. ${ }^{18}$ Met het begrip doel ik op de wijze waarop een individu of groep is betrokken op verleden, heden en toekomst. ${ }^{19}$ Welk tijdperspectief krijgt gestalte in een bepaalde verbeelding van leden van de suburbane middenklasse? Ofwel, oriënteren buitenwijkbewoners zich daarin voornamelijk op de toekomst, of juist op het verleden? En, hoever kijken zij vooruit of terug? Ofwel, waar ligt voor hen de tijdhorizon? ${ }^{20}$ Welk beeld komt bijvoorbeeld tot stand van Toms leefwijze, als deze het liefst veiligstelt wat hij in het verleden heeft bereikt, terwijl de rest van de straat blind vertrouwt op wat gaat komen? Wat betekent het voor zijn bestaan dat zijn vrouw Betsy de toekomst zoveel mogelijk positief tegemoet treedt, terwijl hijzelf voornamelijk terugblikt?

Hoe groot is bovendien de sociale druk op Tom, wanneer blijkt dat zijn oriëntatic op het verleden hand in hand gaat met een onver- 
mogen zelfverzekerd beslissingen te nemen en daadkrachtig plannen te realiseren? Welke indruk ontstaat van het suburbane Westport, als toekomstgerichtheid wordt geassocieerd met vastberadenheid en presteren, terwijl de neiging tot terugblikken wordt gepaard aan angst en afhankelijkheid? Temporele oriëntatie, zo laat ik in de komende hoofdstukken zien, is meer dan slechts terugkijken of vooruitblikken. Ze houdt altijd een handelingsoriëntatic in, bijvoorbeeld een gerichtheid op eigenhandig iets ondernemen of juist op afwachten en volgen, een verlangen naar autonomie of juist de neiging tot conformisme. In de verbeelding van suburbia gaat de kijk op tijd hand in hand met een visie op het doen en laten van de suburbanisant.

Een eenzijdige, veelal negatieve verbeelding mag dan dominant zijn, andere beelden van de buitenwijk blijken wel degelijk mogelijk. Waar het in dit proefschrift om gaat, is welke constanten de verbeelding van de buitenwijk organiseren en in welke gedaanten suburbs en hun middenklasse ook nog vallen aan te treffen. Natuurlijk is de buitenwijk ook in dit boek een ruimte die bewoners tot een woonplaats maken. Verbanden tussen space en place, zoals geografen het uitdrukken, en de levensstijl in suburbia blijven relevant. Willen we echter beter begrijpen hoe dominante constructies in elkaar steken en hoe alternatieven er precies uitzien, dan zullen we de verbeelding van ruimte moeten begrijpen als een verbeelding waarin ook steeds tijd gestalte krijgt. Juist de wijzen waarop verbanden tussen de temporele orièntatie en de levensstijl en handelingsoriëntatie van de suburbane middenklasse worden opgevoerd, dragen bij aan een robuuste representatie. In interpretaties van verbeeldingen die daarvan verschillen, zal de aandacht dan ook met name naar deze verbanden moeten uitgaan. 


\section{Omschrijvingen, definities,} opsommingen en geschiedenissen

\subsection{Een wildgroei van termen}

Waar ik tot nu sprak van 'de suburb', 'suburbia' en 'de buitenwijk' suggereerde ik een eenduidigheid die slechts kon overtuigen doordat vele andere termen uit de tekst zijn geweerd. Zelfs als we ons beperken tot buitenwijken waarin woningen van de middenklasse staan, dient zich in het suburbiadiscours een groot aantal begrippen aan die ook in dit hoofdstuk zouden hebben kunnen worden opgevoerd. Niet ter sprake kwam bijvoorbeeld het onderscheid tussen planned en unplanned suburban subdivisions, tussen residential en industrial suburbs, high density city suburbs en satellite suburbs en tract suburbs, exurbs en reluctant suburbs of suburbs by invasion. Niet aan de orde waren verder de verschillen en overeenkomsten tussen semisuburbs, pseudosuburbs, rurban places en de city-suburb en tussen recente dysurban regional grids of subdivisions, non-place urban fields, edge cities, techno-city, technoburb, outer city, suburban city, exopolis, disurbia en postsuburbia. Onbesproken bleven ook de graying inner suburban ring, ethnoburbs en African American suburbs, evenals de diskwalificaties slurbs en disturbia.

Op het eerste gezicht lijkt misschien sprake van een wildgroei van begrippen. Niet van elke term is duidelijk wat hij precies aan de reeks toevoegt. De meeste leveren echter een productieve bijdrage aan het denken over de buitenwijk. Als een suburb in een bepaalde tekst in een concrete gedaante opduikt, bijvoorbeeld in een casusstudie of roman, bepalen voornamelijk particuliere details haar karakter. Wegen zijn bochtig of juist niet, gazonnetjes liggen er verzorgd of juist verwaarloosd bij en gezinnen hopen groter te gaan wonen of doen juist een stapje terug. Teksten waarin een algemener beeld wordt geschetst, worden vaak ingeleid met pogingen om in de veelheid aan bijzondere eigenschappen samenhang aan te bren- 
gen. Dat gebeurt vaak in de vorm van een definitie, een opsomming van elementen of een geschiedenis. Hoe lastig ook, pogingen om op deze wijzen in diversiteit eenheid aan te brengen, maken het mogelijk om uiteenlopende teksten met elkaar te vergelijken. Ze helpen te bepalen hoe deze zich tot elkaar verhouden, helpen aan te geven waarin ze overeenkomen en verschillen.

\subsection{Omschrijvingen, definities en opsommingen}

Vrijwel elke tekst die poogt een definitie te geven van het Amerikaanse suburbia wordt ingeleid met een opmerking over hoe lastig dat is. ${ }^{21}$ Een traditionele manier om desalniettemin het begrip inhoud te geven, is een omschrijving in termen van wat de buitenwijk niet is. Ze is stad noch platteland. Niettemin zou ze het beste uit beide werelden weten te combineren, bijvoorbeeld doordat ze er strategisch tussenin ligt, of doordat ze eigenschappen van beide in zich draagt. Een belangrijke rol in deze opvatting speelt de metafoor van het huwelijk. Haar belangrijkste uitdrukking krijgt ze in Ebenezer Howards typering van de Garden City, een negentiendeeeuws Engels gemeenschapsideaal dat wordt beschouwd als inspiratiebron voor Amerikaanse suburbs in de twintigste eeuw. 'Town and country must be married (...),, ${ }^{22}$ betoogt Howard in Garden Cities of To-morrow (1898)(Howard (1965): p. 48). Het huwelijk garandeert volgens hem, en de denkers die hij inspireert, behoud van rurale deugden in een industrialiserend en verstedelijkend landschap. ${ }^{23}$ In het artikel 'City and Country: Marriage Proposals' (1968) spreekt Scott Donaldson zelfs van de oplossing van een paradox die de Verenigde Staten van meet af aan heeft gekenmerkt, namelijk die van een voortdurende verering van het plattelandsbestaan in een land waar de 'pull of progress' een steeds stedelijker samenleving oplevert (zie Donaldson (1968): pp. 547-8). ${ }^{24}$ Tuinstad en suburb bieden ruimte voor urbane activiteiten die zorgen voor welvaartsgroei, terwijl de rust en schoonheid van een landelijk bestaan behouden blijven.

Spreken van een combinatie van het beste van twee werelden is volgens filosoof René Boomkens een positieve manier om te zeggen dat suburbia een tussenstatus heeft. Volgens Boomkens ligt het tussen twee werkelijkheden in. Het is noch echt natuur, noch echt stad, 
schrijft hij (zie Boomkens (1998): p. 247). Nu kunnen we ons afvragen wat 'echt stad' of 'echt natuur' inhoudt en bovendien wat er minder werkelijk is aan de buitenwijk, maar er zijn veel omschrijvingen te vinden die overeenkomen met Boomkens' tussenstatus. In Baldassare's Trouble in Paradise wordt suburbia geìntroduceerd als een restcategorie. Het geldt als buffer tussen stad en land en als een gebied met een ambigu karakter (zie Baldassare (1986): p. 3). Suburbaan wonen wordt zelfs expliciet verdedigd als de kunst van ambiguĭteit, schrijft Daniel Miller naar aanleiding van een boek waarin de buitenwijk Dunroamin wordt opgevoerd. 'There are the half timbered walls of the "semi-detached" homes for the "middle" classes set on sub urban estates,' citeert Miller (Miller (1984): p. 46). Vergelijkbaar is de beschrijving waarmee de bundel Visions of Suburbia wordt ingeleid. De suburb geldt er als de belichaming van het verlangen: 'to create for middle class middle cultures in middle spaces in middle America (...)' (Silverstone (1997): p. iii). Suburbia ligt ergens tussenin. ${ }^{25}$

Dat de typering middle niet per se een negatieve is, kan bijvoorbeeld blijken uit de hooggestemde verwachtingen van de middle settlements in het Greenbelt Town Program onder Roosevelts New Deal. Vaker echter staat het middle landscape voor een ontsporend suburbia. De buitenwijk geldt als 'the nightmare of a no man's land between two ideal extremes', verwoordt Donaldson het oordeel van critici (Donaldson (1968): p. 563). In de loop van de twintigste eeuw zou de suburb verworden tot een 'dim, dull, basically unreal world', voegt hij daaraan toe, 'a hazy half-world' waarin niet meer het beste, maar het slechtste van twee werelden bijeenkomt. Illustratief is de ontwikkeling die John Burchard en Albert Bush-Brown schetsen in The Architecture of America (1961). Konden vroegere suburbs misschien nog een bescheiden aanspraak maken op een eigen karakter, moderne varianten zijn in hun optiek niet meer dan verzamelingen anonieme gebouwen. Zij zijn een verraad van zowel stad als land, 'too scattered to provide any of the advantages of the city, too anonymous to provide any of the community spirit of the village'. 'Americans,' luidt de conclusie, 'succeeded in averaging down both the city and the village' (Burchard en Bush-Brown (1961): p.121). ${ }^{26}$

Naast deze formuleringen in termen van eigenschappen van de omgeving bestaan ook definities van de buitenwijk waarin haar 
'eigen' kenmerken centraal staan, zij het opvallend weinig. Vaak lijkt te worden voorondersteld dat het noemen van het begrip 'suburbia' volstaat. Veel minder teksten worden ingeleid met een gedetailleerder begripsbepaling. Dat 'suburb' zoiets betekent als 'voorbij de stad', daarover heerst nog wel overeenstemming. De strekking van minder algemene formuleringen wordt al snel betwist. Dat geldt ook voor die van The United States Bureau of the Census, niet alleen vanwege het statische karakter - dat vrijwel alle definities kenmerkt -, maar ook vanwege de politieke druk waaronder ze tot stand zou zijn gekomen. Toch is de definitie van het U.s. Census Bureau een van de meest gehanteerde, al dan niet in aangepaste vorm. Volgens deze zijn suburbs satellietgemeenten in het gebied buiten de gemeentegrenzen van een centrale stad waarvan veel van de inwoners binnen de stadsgrenzen werken of elders banen hebben die hen aan de stadseconomie binden en die bovendien voor veel commerciële, medische en culturele voorzieningen van de centrale stad afhankelijk zijn. ${ }^{27}$

Definities als deze roepen gemakkelijk vragen op. Worden gemeenschappen aan de stedelijke rand die formeel wel tot de stad behoren bijvoorbeeld niet ook als 'suburbaan' bestempeld? Hoeveel van de inwoners van een randgemeente moeten in de centrale stad werkzaam zijn, willen we van een suburb spreken? En hebben oudere, nabijgelegen suburbs soms niet veel meer gemeen met de stad dan met andere, jongere en verder weg gelegen buitenwijken? Deze en andere vragen lijken vaak aanleiding om van definiëring af te zien. Vaker dan een definitie treffen we een opsomming van elementen aan. Uitgangspunt daarbij is dat hoewel veel van deze elementen terugkeren in de meeste omschrijvingen, er niet één hoeft te zijn die in allemaal is terug te vinden. Een kenmerk van veel buitenwijken is bijvoorbeeld dat er alleen wordt gewoond, maar dat geldt niet voor de industrial suburb. De meeste buitenwijken hebben een betrekkelijk lage woondichtheid, sommige graying inner suburbs echter niet. Een eigen eengezinswoning wordt traditioneel gezien als een van de belangrijkste kenmerken van suburbaan wonen, terwijl in het recente disurbia of postsuburbia steeds meer mensen een appartement huren. Veel suburbs zijn relatief groen, maar niet allemaal. In veel buitenwijken wonen traditioneel vooral kerngezinnen, maar steeds vaker ook huishoudens met een andere samenstelling. 
Steeds meer bewoners zijn niet meer aan te merken als jong en veelbelovend en steeds meer suburbs zijn al lang niet meer blank. ${ }^{28}$

Een opsomming van dergelijke kenmerken levert geen verzameling eigenschappen op waarvan we kunnen vaststellen of ze volledig is. Ze resulteert niet in een reeks termen waarmee we tot een alomvattende omschrijving van suburbia kunnen komen. Wel kan ze dienen als basis voor groepen kenmerken waarmee we verschillende soorten buitenwijken kunnen onderbrengen in een typologie. Een dergelijke ordening komt met name tot stand in teksten die streven naar structurering van de variatie aan suburbs die op een bepaald moment valt aan te treffen. ${ }^{29}$ Wordt echter niet zozeer gesproken van een (statisch) verschijnsel, maar eerder van een proces (van suburbanisatie), dan voldoen opsommen en rubriceren niet meer. Wie eenheid wil aanbrengen in de vorm van een geschiedenis, dient uiteenlopende kenmerken onder te brengen in cen verhaal.

\subsection{Geschiedenissen}

In uiteenlopende teksten treffen we suburbia aan in historische narratieven. Het meervoud is hier cruciaal. Zoals ik hierboven in mijn kritiek op het repertoire van de mythe niet sprak in termen van het ware verhaal over de suburbane werkelijkheid, zo kunnen we ook hier niet spreken van de ware geschiedenis van de buitenwijk. Ik bedoel niet dat we afzonderlijke uitspraken over historische buitenwijken niet 'waar' of 'onwaar' kunnen noemen. Zo kunnen we de bewering dat Llewellyn Park (een suburb in New Jersey's Orange Mountains) al in de jaren veertig van de negentiende eeuw wordt gebouwd 'onwaar' noemen, omdat we weten dat pas in de jaren vijftig de eerste grond wordt aangekocht. Het gaat erom dat een historisch verhaal meer is dan een optelsom van dergelijke uitspraken over het verleden. Zo'n verhaal houdt allereerst een selectie in uit de vele mogelijke uitspraken over het verleden. Bovendien organiseert het de gekozen uitspraken zodanig dat daartussen een bepaalde samenhang totstandkomt. Deze levert een betekenisvolle eenheid op die met de afzonderlijke uitspraken nog niet gegeven was. Ze krijgt pas in en door het verhaal gestalte. In en door het verhaal krijgt het verleden op deze wijze een narratieve betekenis. ${ }^{30}$ 
Wat in de ene interpretatie zus wordt geduid, wordt in de andere zo opgevoerd. Wordt Llewellyn Park bijvoorbeeld in een ontwerpgeschiedenis neergezet als een vroeg voorbeeld van fraai suburbaan wonen, daar wordt het in een meer op het sociale georiënteerde geschiedenis gekarakteriseerd als een voorloper van sociaal-economische en etnische segregatie. En waar in de ene geschiedenis de gegoede burgerij wordt opgevoerd als een klasse die op eigen houtje een ideaal verwezenlijkt, daar kan ze in een andere bijvoorbeeld niet zonder vernieuwingen in riooltechnologie en diensten van de arbeidersklasse. Afhankelijk van het gekozen perspectief wordt een bepaald verhaal verteld, waarin een specifieke versie van de geschiedenis van suburbia gestalte krijgt. In verschillende ontwikkelingen die zo worden geschetst, valt een buitenwijk als Llewellyn Park en haar bewoners in verschillende gedaanten aan te treffen. Deze liggen niet in het verleden op ons te wachten, maar komen tot stand in de verhalen waarin ze worden opgevoerd.

Een aantal verschillende versies van de geschiedenis van suburbia zal in de komenendê hőfdstukkkên dê fêvuê påssêfen. Sommingê daarvan zijn nauwelijks met elkaar te verenigen. In andere worden kritische kanttekeningen geplaatst bij sommige interpretaties, maar worden andere onderschreven. Weer andere vullen elkaar moeiteloos aan. Een aantal is zelfs gemeengoed geworden. Putten we uit deze rijke voorraad en besteden we voornamelijk aandacht aan de minder controversiële verhalen, dan is een inleidende geschiedenis samen te stellen. Deze is wellicht weinig specifiek, maar kan wel dienst doen als een eerste impressie van de wijze waarop, naast definitie en opsomming, een historische samenhang in de suburbane diversiteit wordt aangebracht. Bovendien kan aan de hand hiervan een aantal inleidende opmerkingen worden gemaakt over gezichtspunten die diverse, specifieke geschiedenissen maken tot wat ze zijn, namelijk vertellingen die niet alleen overeenkomsten vertonen, maar evenzeer op belangrijke punten van elkaar verschillen. 
In de verbeelding van suburbia spelen buitenwijken uit de jaen vijftig de hoofdrol. Gevraagd naar een korte typering van subrbaan leven, schetst menigeen een beeld van een naoorlogse tract sb$u r b$. Daarin figureert meestal de homogene gemeenschap van joge gezinnen in de rustige, beetje saaie en eenvormige omgeving dieve hierboven tegenkwamen in Baldassare's en Bergers omschrijungen. De buitenwijk verschijnt als vluchtoord voor een overwegad blanke middenklasse die, volgens Jon Teafords The Twentieth-Certry American City (1986), een bestaan leidt 'among those of simar income, lifestyle, and complexion', een bestaan waarin buren btzelfde denken en handelen en er ook nog hetzelfde uitzien (Teafrd (1993): p. 104). Deze suburbs zijn 'small, controlled communities in termen van columnist Erma Bombeck, 'where for the most prt everyone has the same living standards, the same weeds, the sane number of garbage cans, the same house plans, and the same levein the sepuć tank' 'żıé jâckson(1987):'p. 4)'

Meestal wordt dit geprefabriceerde, volgens velen monotone wonen geillustreerd door de eerste van de drie Levittowns, een grootschalig project waarmee eind jaren veertig op Long Island wordt begonnen. Met zijn bescheiden, vrijstaande huizen die in een beperkt aantal varianten worden aangeboden en die aan gekromde wegen door een eenvoudig, maar zorgvuldig ingericht landschap staan, wordt het beschouwd als de standaard voor naoorlogs NoordAmerikaans suburbia. Met zijn enorme omvang en met name door de grote aantallen mensen die er zich een eigen woning kunnen veroorloven, geldt het project als een nieuw fenomeen. Tegelijkertijd echter, zo wordt in uiteenlopende geschiedenissen betoogd, is dit type planning een product van een lange ontwerptraditie. Hoewel gereduceerd tot zijn eenvoudigste en goedkoopste vorm, schrijft Michael Bunce bijvoorbeeld in zijn landschapsgeschiedenis The Countryside Ideal (1994), ligt aan Levittown eenzelfde ideaal ten grondslag als aan exclusieve romantic suburbs als Palos Verdes buiten Los Angeles, comfortabele garden suburbs als Forest Hills Gardens buiten New York, Engelse tuinsteden als Letchworth en vroege suburbs als het Londense Park Village (zie Bunce (1994): Pp. 153-69).

De wieg van de buitenwijk staat in verschillende teksten in ver- 
schillende landen. In Jacksons Crabgrass Frontier draagt suburbia nadrukkelijk het label made in the U.S.A.. Overtuigender vinden de meeste(stads)historici echter geschiedenissen waarin de eerste suburbs in Engeland liggen. In zowel Robert Fishmans Bourgeois Utopias (1987) als John Stilgoe's Borderland (1988) is het de Engelse bourgeois die aan het einde van de achttiende eeuw de steeds vollere stad verlaat om op het platteland comfortabele villa's te betrekken. Dat wil zeggen, vermogende kooplui en bankiers gaan buiten de stad wonen, terwijl ze in het centrum hun lucratieve zaken blijven doen. In de eerste helft van de negentiende eeuw krijgen steden als Londen, Manchester en Liverpool de structuur van een reeks concentrische cirkels. Het hart van de stad fungeert steeds meer als zakencentrum. Daaromheen wonen arbeiders te midden van de fabrieken waarin zij werken. Daarbuiten ontstaat voor het welvarendste deel van de burgerij een ring van riante woonhuizen aan bochtige weggetjes in een parkachtige omgeving. $\mathrm{Zij}$ die het kunnen betalen, zonderen zich af in sociaal homogene wijken als Victoria Park. De hoge kosten van een dagelijkse reis naar de stad per rijtuig garanderen de scheiding der klassen. In sommige gevallen doen muren en toegangspoorten de rest.

Dit woongenot blijft in de Verenigde Staten niet onopgemerkt. Als de industrialisatie er voet aan de grond krijgt en de steden in hoog tempo groeien, neemt ook daar de middenklasse haar toevlucht tot de buitenwijk. Vanaf het midden van de negentiende eeuw vertalen hervormingsgezinde intellectuelen zoals Catherine Beecher, Andrew Jackson Downing, Calvert Vaux en Frederick Law Olmsted het Engelse ideaal naar de Amerikaanse situatie. Zij prijzen het suburbane leven als een complex van morele deugden, natuurlijke rust en ontworpen schoonheid en als een combinatie van de voordelen van het leven in de stad met die van het wonen op het platteland. In kranten wordt dit bestaan lyrisch beschreven, in tijdschriften als Country Life en Suburban Life wordt het succesvol gepromoot. Fysiek krijgt het suburbane ideaal gestalte in exclusieve suburbs als Riverside buiten Chicago, Illinois. Het zorgvuldige landschapsontwerp geeft er samen met de bijpassende architectuur van woonhuizen uiting aan de opvatting dat een gezond en stabiel gemeenschaps- en gezinsleven slechts kan bloeien in een elegante, groene en rustige omgeving. Bovendien makkt een dergelijk ont- 
werp de status zichtbaar die bewoners op basis van zakelijk succes hebben verworven.

Sommige geschiedenissen besteden uitvoerig aandacht aan de wijze waarop deze upper-middle class haar woonomgeving vormgeeft. Soms lijkt ze autonoom een visie te formuleren en deze vervolgens daadkrachtig te verwezenlijken. In andere interpretaties handelt ze uitdrukkelijk in een uitgebreide economische, socialeen technologische context. De aandacht gaat bijvoorbeeld uit naar de fabrieksarbeid die het vermogen oplevert dat nodig is om suburbaan te kunnen wonen, naar (inwonende) zwarte bedienden die blanke huishoudens helpen draaiende te houden en innovaties in sanitaire voorzieningen. Met name veranderingen in transporttechnologie krijgen in diverse vertellingen de ruimte. Zo wordt het belang van de trein benadrukt. Het spoor maakt de relatief ver van de stad gelegen suburb voor de vermogende burger bereikbaar, terwijl het met zijn hoge reiskosten andere lagen van de bevolking op afstand houdt. Daarin komt verandering met de komst van de elektrische streetcar. Rond de eeuwwisseling maakt deze trolley forenzen veel goedkoper. Daarmee wordt een groot gebied tussen de buitenste suburbs van de upper-middle class en de arbeidersgemeenschappen in de industriezones van de centrale stad voor een steeds bredere laag van de middenklasse geschikt als woonomgeving. ${ }^{31}$ Omdat deze ruimte dunbevolkt is, is de grond betaalbaar. Bovendien maken steeds eenvoudiger constructiemethoden de bouw van woningen goedkoper en vergemakkelijken nieuwe hypotheekvormen de aanschaf van een eigen huis.

Een gestaag groeiend aantal gezinnen vestigt zich in de suburbane periferie. Vele daarvan behoren tot de zogeheten new middle class. Als ambtenaar, technicus, verkoper, kantoorklerk en manager verdient zij een middeninkomen waarmee ze zich een vrijstaand huis buiten de stad kan veroorloven. Vergeleken met de exclusieve enclaves van de elite, is de buitenwijk waarin dit huis komt te staan minder mooi gelegen en minder fraai vormgegeven. ${ }^{32}$ Hoewel grondspeculanten en projectontwikkelaars de idealen van Downing en Olmsted handig in hun promotiecampagnes verwerken, delven deze in de praktijk met het oog op efficiency en winst vaak het onderspit. Percelen krimpen, de verhouding tussen grijs en groen wordt minder luxueus en omdat woningen betaalbaar moeten zijn, 
dient hetzelfde ontwerp vaak als blauwdruk voor een groot aantal huizen. Ruim voor de Tweede Wereldoorlog, zo wordt in de meeste vertellingen betoogd, wordt de basis gelegd voor de standaardisatie die buitenwijken vanaf de jaren vijftig gaat kenmerken.

In geschiedenissen met de nadruk op het contrast tussen verschillende klassen geldt het suburbia van deze nieuwe middenlaag als een homogene gemeenschap: dezelfde beroepen, dezelfde huizen, dezelfde angsten en verwachtingen. In vertellingen die meer in detail op deze gemeenschap de aandacht vestigen, blijft van deze homogeniteit niet veel over. De nieuwe middenklasse, zo luidt al dan niet expliciet de stelling, hecht veel belang aan zelfs de geringste verschillen in inkomen, geloof en etniciteit. Doordat met het stijgende autobezit ook het gebied tussen de streetcar-corridors voor de forens toegankelijk wordt, is er voldoende ruimte voor een mozaïek van suburbs met elk een eigen status.

Als symbool van technologische en economische vooruitgang belichaamt de auto in de meeste vertellingen het optimisme waarmee vele jonge gezinnen die suburbs opzoeken. Een eigen wagen geldt zelfs als teken van wat wel de democratisering van suburbia wordt genoemd. Steeds meer Amerikanen genieten van een snel stijgende welvaart. Ook een groeiend deel van de lagere middenklasse en de arbeidersklasse kan de periferie opzoeken. Voor velen van hen gaat een droom in vervulling. Wat veel intellectuelen beschouwen als benauwd wonen in uitermate treurige tracts, is voor hen ruimer en rustiger leven in een nieuw huis met een eigen tuin. Vatten we democratisering echter niet alleen op als sociaal-economische, maar evenzeer als etnische en raciale toegankelijkheid van suburbia, dan laat zich een ander verhaal vertellen. Voor veel minderheden is dat nieuwe huis met die eigen tuin door zowel federaal als lokaal overheidsbeleid, verkooppraktijken van makelaars en projectontwikkelaars en acties van buurtbewoners decennialang vrijwel onbereikbaar. Veel blanke arbeiders kunnen zich al in de jaren vijftig in een buitenwijk vestigen, leden van een vermogender, maar zwarte middenklasse, bijvoorbeeld, zijn daartoe vaak pas in de jaren zeventig in staat.

Er worden nog meer kritische noten gekraakt. Forenzende mannen zouden door lange reistijden hun gezin nauwelijks zien. Vrouwen zouden overdag eenzaam zijn en tot niet meer in staat worden 
gesteld dan het eindeloos heen en weer rijden van de kinderen. Kinderen zouden worden verwend of juist verwaarloosd en zouden daarnaast door de rigide sociale indeling van suburbia onvoldoende in contact komen met anderen dan zijzelf. Bovendien zouden grootschalige woningbouwprojecten het platteland opslokken. Bouwen in de periferie zou onvermijdelijk leiden tot verkeerscongestie, groeiende woon-werkafstanden zouden de lucht vervuilen, eindeloze rijen prefab-woningen de horizon.

Hoe dan ook, tientallen miljoenen Amerikanen kiezen in de loop van de jaren vijftig en zestig voor een huis in de suburb. De Verenigde Staten worden een overwegend suburbane natie. Afhankelijk van de interpretatie wordt gesproken van de hoogtijdagen van de buitenwijk of van een suburbia dat aan zijn eigen succes ten onder gaat. In de loop van de jaren zeventig blijft het aantal inwoners snel groeien. Bovendien verandert de suburbane bevolking van samenstelling, zowel in sociaal-economisch en etnisch opzicht als qua gezinsopbouw. Kinderen groeien op en verlaten het ouderlijk huis. Het aantal echtscheidingen neemt toe en đảarmee aẻ vraag naar kleinere woningen. Met het aantal ouderen stijgt de behoefte aan appartementencomplexen met gedeelde voorzieningen en zorg. Tweeverdieners kiezen voor woningen die strategisch tussen twee werkplekken in liggen. Voor veel starters op de arbeids- en woningmarkt worden de oude streetcar-buitenwijken en de tracts onbetaalbaar. En aan stadsranden ontstaan zogeheten graying inner suburbs waar veelal lagere inkomensgroepen en etnische minderheden onderdak vinden.

Bovendien raakt suburbia in trek bij het bedrijfsleven. Zowel de industrie-als de dienstensector profiteert er van lagere grondprijzen en belastingen en een betere bereikbaarheid. Grote bedrijven vestigen kantoren in gloednieuwe bedrijvenparken en regionale shopping malls worden steeds groter, waardoor buitenwijkbewoners steeds minder vaak voor werk of boodschappen de binnenstad in hoeven. Geleidelijk ontstaat een gedecentraliseerd, multifunctioneel metropolitaan gebied waarin reizen van de ene plek in de periferie naar de andere belangrijker wordt dan het klassieke pendelen tussen suburb en centrum. In beschrijvingen van deze huidige fase in de ontwikkeling van suburbia worden termen als 'urbaan', 'ruraal' en 'suburbaan' nauwelijks meer bruikbaar geacht. Er wordt gespro- 
ken van een complex, polycentrisch netwerk met de gecombineerde kenmerken van stad, buitenwijk en platteland: wonen $e n$ werken, hoge $e n$ lage dichtheid, parkeerplaatsen $e n$ grasland, recreëren $e n$ criminaliteit. De interpretaties ervan lopen uiteen. In de ene geschiedenis wordt betoogd dat er sprake is van veranderingen in en van suburbia en wordt de voorlopige uitkomst opgevoerd onder de noemer transformed suburbs - bijvoorbeeld in Baldassare's Trouble in Paradise. In de andere is sprake van een periode na suburbia, maar kan nog worden gesproken van een postsuburban region, omdat deze zich heeft ontwikkeld vanuit het traditionele suburbia - bijvoorbeeld in Kling, Olin en Posters Postsuburban California (1991). In weer andere, tot slot, is het met de buitenwijk gedaan. Er wordt een fase ingeluid waarin het metropolitane gebied radicaal verschilt van dat uit het suburbane tijdperk. Fishman munt in Bourgeois Utopias en 'Die neue Stadt des 20. Jahrhunderts' (1994) bijvoorbeeld termen als techno-city en technoburb. 


\title{
De buitenwijk als inzet
}

\author{
en uitkomst van debat
}

De eenheid die in de vorm van omschrijvingen, definities, opsommingen en geschiedenissen in de veelheid aan verschijningsvormen van de buitenwijk wordt aangebracht, komt tot stand op een strijdtoneel. Sommige van de genoemde termen en interpretaties vullen elkaar aan, de meeste concurreren echter met elkaar. We dienen ons af te vragen hoe de teksten warin ze worden uitgewerkt zich tot elkaar verhouden. Wat hebben ze gemeen? Waarin verschillen ze? Waarom past een bepaalde gedaante van de buitenwijk juist wel in deze, maar niet in die interpretatie? Welk effect gaat ervan uit als de suburb in de ene tekst dit symboliseert en in de andere dat?

\subsection{Sociaal-en geesteswetenschappelijke studies}

In sociaal- en geesteswetenschappelijke studies is suburbia al minstens een eeuw inzet van diverse debatten. Deze zijn veelal disciplinegebonden. Economen besteden bijvoorbeeld aandacht aan de functionele relatie tussen stadskern en omringende regio, geografen letten eerder op zaken als woondichtheid en patronen in woonwerkverkeer, architecten gaat het primair om het type gebouwen, sociologen lokaliseren in suburbia een bepaalde levenswijze en cultuurfilosofen zijn onder meer geïnteresseerd in in- en uitsluitingsmechanismen. Hoewel in dit proefschrift is gekozen voor een interdisciplinaire benadering, is het zinvol om een inleidende opmerking te maken over belangrijke kwesties op de agenda's van de disciplines die in dit onderzoek worden betrokken. De gedaanten waarin we de buitenwijk en haar bewoners zullen aantreffen, hangen met deze kwesties nauw samen.

In historische debatten is de rol van de middenklasse in de ontwikkeling van het suburbane ideaal belangrijk. Dat zij een grote rol 
heeft gespeeld, staat niet ter discussie, wel hoe deze zich verhoudt tot bijvoorbeeld de opkomst van nieuwe vervoers- en bouwtechnologieën, veranderende verhoudingen van vraag en aanbod op de woningmarkt en de verdeling van overheidsgelden. Een andere kwestie is wanneer zich voor het eerst arbeiders en etnische minderheden in suburbia vestigen. Tegen de heersende opinie in betogen sommige stadshistorici bijvoorbeeld dat de bevolking in suburbia al aan het begin van de twintigste eeuw even divers is als die in de steden, waarmee zij de betekenis van de dichotomie 'stad - suburb' en die van daarmee verbonden paren als 'arm - rijk' en 'heterogeen - homogeen' in twijfel trekken. ${ }^{33}$

In sociologische debatten is de vraag naar de specifieke kenmerken van de suburbane middenklasse een belangrijke. Ze zou, met name in de beginjaren van de buitenwijk, autonoom, visionair en handelingsbekwaam zijn. Ze zou gesteld zijn op privacy en zich voorzichtig richten op vooruitgang. Maar ook onderlinge bemoeizucht wordt genoemd, zeker in verband met de buitenwijk van de jaren vijftig, evenals conformisme, nostalgie, conservatisme, lafheid, seksisme en racisme. Welk type gemeenschap levert dit op? Hoe staat ze bijvoorbeeld tegenover verandering en groei, hoe tegenover sociaal-economische, etnische en raciale segregatie? En hoe verhoudt ze zich tot de kloof tussen arm en rijk die met name in de jaren tachtig onder Ronald Reagan steeds groter wordt, tot wat wel de disappearing middle class wordt genoemd?

Hieraan nauw verwante vragen staan in zowel de cultuurfilosofie als de sociale en culturele geografie centraal. Betekent de buitenwijk democratisering van comfortabel wonen en is ze daarmee een van de verworvenheden van de moderniteit? Zo ja, wie kunnen daarvan genieten en wie niet? Hoe is de openbare ruimte bijvoorbeeld ingericht? Een belangrijke kwestie is of suburbia al dan niet de overwinning van privé op publiek betekent, van narcisme op betrokkenheid. Daaraan gepaard gaat een discussie over de vermeende teloorgang van stedelijke diversiteit en dynamiek in de buitenwijk. Hoe levendig is suburbia, hoe voorspelbaar?

In debatten over de vormgeving en architectuur van de suburb, tot slot, staat onder meer de esthetische kwaliteit van woningen en wijken op de agenda. Gaf de burgerij aanvankelijk zelfverzekerd vorm aan mooie, ruime woningen in een park of stemde ze haar 
smaak eenvoudig af op die van de landadel? Getuigen de latere tracts van de lagere middenklasse van slechte smaak of moeten intellectuelen anders leren kijken? En wat zegt een huis in Spanish Colonial Revival-stijl over zijn bewoners? Waarom staat er een Cadillac met grote vinnen op de oprit?

Verschillende antwoorden op deze en andere vragen leveren een ander suburbia op. Wat de buitenwijk is, kan niet worden beschouwd als een gegeven. Het dient te worden begrepen als een bevochten en steeds te bevechten, voorlopig resultaat. Dat resultaat treffen we in uiteenlopende studies aan in de vorm van verschillende gedaanten van de buitenwijk en haar bewoners.

\subsection{Literaire verhalen}

Suburbia duikt ook in literaire verhalen in uiteenlopende gestalten op. Literatuurwetenschapster Marilyn Chandler spreekt zelfs van een literair genre waarin het suburbane bestaan centraal staat: a literature of the suburbs (Chandler (1989): p. 215). De verbeelding in dat genre is interessant, betoogt ze. Het kan ons bijvoorbeeld bewust maken van de metaforische dimensie van het denken en handelen in de buitenwijk. Ook René Boomkens betrekt literaire verhalen in zijn bespiegelingen over het suburbane bestaan. Willen we bijvoorbeeld iets te weten komen over de upper-middle-class buitenwijken rond Los Angeles, dan moeten we volgens hem niet alleen het werk lezen van socioloog Richard Sennett en architectuurcriticus Charles Jencks, maar evenzeer Bret Easton Ellis' roman Less than Zero (1985).

Waar wetenschappelijke betogen zich veelal expliciet tot elkaar verhouden, zijn intertekstuele verbanden tussen literaire verhalen vaak impliciet. Het grensverkeer tussen korte verhalen en romans neemt bijvoorbeeld de vorm aan van al dan niet gemakkelijk herkenbare toespelingen, al dan niet letterlijke ontleningen en contrasten. Hoewel in de literatuur niet zoals in de sociale en geesteswetenschappen kwesties expliciet op de agenda staan, zijn topoi aan te wijzen die als thema's en motieven in diverse verhalen terugkeren. Een aantal daarvan is nauw verwant aan de kwesties die ik hierboven noemde. In Wilsons The Man in the Grey Flannel Suit, bijvoorbeeld, is de relatie tussen nostalgie en vooruitgang een centraal 
thema en staan tegenstrijdige opvattingen over de inrichting van het suburbane landschap tegenover elkaar. In Keats' The Crack in the Picture Window worden tracts gekritiseerd, in Karps Leave Me Alone, John Updike's Rabbit, Run (1960) en Yates' Revolutionary Road maken de echtparen Douglas, Angstrom en Wheeler verschillende afwegingen tussen conformisme en autonomie, in Updike's Couples (1968) speelt gebrek aan betrokkenheid bij het publieke domein een belangrijke rol. In Ira Levins The Stepford Wives (1972) zijn suburbane huisvrouwen nauwelijks te onderscheiden van robots, in Ellis' Less than Zero heeft in de buitenwijk helemaal niemand meer gevoel. In Raymond Carvers bundel What We Talk About When We Talk About Love (1981) blijven mannen eenzaam achter in hun suburbane woning, in Alice Hoffmans Local Girls(1999) zijn het de vrouwen. In Gloria Naylors Linden Hills (1985), tot slot, zijn het niet blanke, maar zwarte suburbanisanten die een ziekelijk streven naar status aan de dag leggen, terwijl het in Douglas Couplands Generation X (1991) juist leden van de blanke middenklasse zijn die hun ambities vaarwel zeggen.

Kwesties als deze treffen we dus niet alleen aan in sociaal- en geesteswetenschappelijke studies, maar evenzeer in literaire verhalen. Ook daarin kan bovendien eenzelfde thematiek in diverse gedaanten van de buitenwijk en haar bewoners uitdrukking krijgen. Sommige daarvan zijn zonder meer eendimensionaal te noemen. Zo is het Rolling Knolls uit The Crack in the Picture Window niet meer dan een karikatuur van de buitenwijken waarvoor het model zou moeten staan en zijn de bordkartonnen hoofdpersonages John en Mary Drone niet meer dan schietschijven voor de gifpijlen van de auteur. Evenmin positief, maar niettemin veel complexer is het beeld in Leave Me Alone en Rabbit, Run. De suburb mag de hoofdpersonages dan benauwend voorkomen, anderen betwisten dat. In deze verhalen krijgen belevingswerelden gestalte waarvan sommige verenigbaar zijn, terwijl andere ook na uitwisseling van argumenten blijven botsen. Dat de kijk op een suburbaan bestaan ook in het leven van een enkel individu kan variëren, laten romans zien waarin na jaren wordt teruggeblikt op het leven in de buitenwijk. Zo is het bijvoorbeeld zonneklaar dat het gezinsleven van de Hoods in het suburbane New Canaan van 1973 in Rick Moody's The Ice Storm (1994) niet op rolletjes loopt. Toch is de toon van de verteller, zoon Paul uit het gezin, niet alleen venijnig, maar evengoed medelevend 
en humoristisch.

Op zoek naar verschillende verschijningsvormen van het middenklassesuburbia zullen in dit proefschrift zowel wetenschappelijke betogen als literaire verhalen worden bekeken. In beide vallen naast eenzijdige verfijnder gedaanten aan te treffen. In dit boek zal niet worden getracht de vraag te beantwoorden wat nu precies een artikel tot een wetenschappelijke tekst maakt en een roman tot een literaire. Wel zullen specifieke buitenwijken uit beide soorten teksten worden vergeleken. Een aantal inleidende opmerkingen over de verhouding tussen literatuur en wetenschap is daarom op zijn plaats.

Van wetenschappelijke en literaire teksten verschillen doorgaans onze verwachtingen. In de eerste verwachten we een betoog, in de tweede een verhaal aan te treffen. In de eerste eenduidigheid, in de tweede veelal meerduidigheid of ambiguìteit. Daarnaast verwachten we bijvoorbeeld dat een wetenschappelijke studie verbanden tussen beweringen over een specifiek geval en die met een algemenere strekking expliciteert, terwijl in een literaire tekst de suggestie van het grote in het kleine volstaat, en zelfs als een uitgesproken kwaliteit wordt beschouwd.

In verschillende disciplines vormen uiteenzettingen als deze over de verschillende soorten inzichten die wetenschap en literatuur ons bieden een opstapje naar de bewering dat verbeelding in de laatste een vruchtbare bijdrage kan leveren aan inzichten uit de eerste. ${ }^{34}$ In het wetenschapsonderzoek pleit Donna Haraway bijvoorbeeld voor de bestudering van literaire fictie. Hoewel zij af wil van de tegenstelling tussen (wetenschappelijk) feit en (literaire) fictie, maakt ze wel een onderscheid tussen beide. In Primate Visions (1989) speelt ze het karakter van de tweede uit tegen dat van het eerste. Fictie, betoogt ze, refereert aan 'a present act of fashioning, while fact is a descendant of a past particle, a word form which masks the generative deed or performance' (Haraway (1989): p. 4). Veel minder dan het (wetenschappelijke) feit verbergt fictie volgens Haraway haar geconstrueerde karakter. Ze laat nadrukkelijk ruimte voor nieuwe interpretaties en betekenissen. 'Fiction seems always inventive,' betoogt ze, 'open to other possibilities, other fashionings of life' (ibid: p. 4) en is daardoor bij uitstek in staat ons te verrassen met nieuwe invalshoeken. ${ }^{35}$

Filosofen die aandacht vragen voor de kracht van literatuur zijn 
bijvoorbeeld Richard Rorty, Martha Nussbaum en Paul Ricoeur. Rorty kiest op belangrijke punten in zijn werk voor literatuur in plaats van filosofie. Beter dan in een theoretische studie, betoogt hij, laten zich in een literair verhaal bijvoorbeeld ervaringen van leed en wreedheid verbeelden. Volgens de Amerikaan zou de schrijver beter dan de theoreticus de zo belangrijke details van het lijden tot uitdrukking kunnen brengen. Bovendien zouden literaire personages veel dichter bij mensen staan dan het subject in wijsgerige teksten. Hun ervaringen zouden meer lijken op de onze. ${ }^{36}$ Ook in Martha Nussbaums werk speelt het detail een belangrijke rol. Doordat volgens haar juist in de literatuur, en veel minder in de wijsbegeerte, aandacht wordt besteed aan het specifieke van een situatie, in plaats van aan het algemene, komen juist die kenmerken van de werkelijkheid tot hun recht die zij van het hoogste belang acht, namelijk de complexiteit en particulariteit van de concrete situatie. Het literaire verhaal, betoogt ze, biedt de scherpte en precisie die we nodig hebben voor onze (morele) oriëntatie in de veelvormige werkelijkheid. ${ }^{37}$

In Paul Ricoeurs werk speelt de literatuur meerdere rollen. Eén daarvan is in het kader van dit proefschrift bijzonder relevant. Fictie, betoogt Ricoeur in het derde deel van Time and Narrative(1983-5), is veel meer dan een illustratie bij een wijsgerig thema: 'it actualizes the universal meaning of this theme in a singular figure' (Ricoeur (1988): p. 134). Fictie is in staat grote thema's zichtbaar te maken in concrete situaties. Eén van die grote thema's is tijd. Een gecompliceerd fenomeen als onze ervaring en ons begrip van tijd, stelt Ricoeur, laat zich uitstekend inzichtelijk maken in een fictioneel verhaal. In een onderzoek naar tijd is literaire verbeelding volgens de Fransman een onmisbaar instrument (zie ibid: p. 14o).

Twee literatuurwetenschappers tonen zich op dit punt verwante geesten: Mikhail Bakhtin en Gary Saul Morson. Beiden zijn gepreoccupeerd met de inzichten die het literaire verhaal ons biedt, in het bijzonder als het gaat om tijd. 'Writers explore what it is to live with a particular conception of time, and what consequences, social, historical, and psychological, a commitment to specific temporalities may produce,' betoogt Morson (Morson (1994): p. 4). Ze zijn daartoe in staat, doordat literaire verbeelding wordt gekenmerkt door een 'wholeness and fullness', zoals Bakhtin het omschrijft 
(Bakhtin (1998b): p. 243), die in betogende teksten ontbreekt. Met name in de roman, schrijft Bakhtin, 'time, as it were, thickens, takes on flesh' (ibid: p. 84). Verschillende concepties van tijd worden niet in abstracte vorm met elkaar geconfronteerd, maar komen tegenover elkaar te staan in de gedaanten van houdingen, perspectieven en gedragingen van verschillende personages. Deze komen bovendien tot uitdrukking in concrete situaties, waarin naast argumenten ervaringen en emoties van groot belang zijn. Juist in deze 'prosaic fineness of daily circumstances and choices', betoogt Morson ((1991): p. 1076), huist de meerwaarde van literatuur. ${ }^{38}$

\subsection{Uiteenlopende teksten als elkaars context}

De gedachte dat verschillen in benadering contact tussen literaire verhalen en wetenschappelijke betogen niet in de weg staan, maar juist interessant maken, is er een die dit proefschrift inspireert. Vergelijken betekent hier niet een confrontatie tussen zoiets als a fiterature of the suburbs en suburban studies in hun algemeenheid. Steeds zullen de wijzen waarop concrete, specifieke buitenwijken en hun inwoners in afzonderlijke teksten opduiken centraal staan. Bovendien zal ik literatuur en wetenschap niet beschouwen als wat wel 'twee domeinen' worden genoemd. In navolging van filosoof Gerard de Vries spreek ik van 'twee tradities'. De Vries kiest voor een recursieve karakterisering van literatuur en wetenschap, een typering in termen van traditie. Hij sluit daarmee aan bij J.J.A. Mooijs antwoord op de vraag wat literatuur is, namelijk dat literatuur datgene is wat in de literaire traditie staat en die traditie op een interessante manier vernieuwt. Zo vormt een artikel een wetenschappelijke tekst, wanneer we het in een wetenschappelijke traditie kunnen plaatsen en het die traditie vernieuwt (zie DeVries (1999): p. 11o). ${ }^{39}$

Uitspraken in zo'n artikel kunnen we lezen tegen de achtergrond van eerdere uitspraken uit de traditie. Ze ontlenen hun betekenis aan de uitspraken waaruit ze voortspruiten en die ze transformeren, schrijft De Vries. Op deze wijze komen in wetenschappelijke teksten nieuwe versies van de wereld tot stand die kunnen concurreren met eerdere wetenschappelijke versies, zoals literaire teksten nieuwe versies van de wereld presenteren die we kunnen waarderen 
door ze in de literaire traditie te plaatsen. Een buitenwijk die in een roman gestalte krijgt, onderscheidt zich in deze opvatting niet van een buitenwijk die in een wetenschappelijke studie wordt opgevoerd, doordat de eerste verzonnen zou zijn en de tweede een werkelijke suburb zou beschrijven. Het verschil tussen een wetenschappelijk werk en een roman, betoogt De Vries, bestaat er niet in dat het eerste naar feiten verwijst, terwijl de tweede deze opmerkelijke prestatie niet kan evenaren. ${ }^{40}$ 'Verwijzen' houdt niet het beschrijven van de werkelijkheid in, maar het zich verhouden tot andere teksten. In die zin verwijzen zowel wetenschappelijke als literaire teksten: beide maken deel uit van tradities waarin elke nieuwe versie van de wereld zich verhoudt tot eerdere versies.

Hoewel bij de bestudering van verschillende versies van het middenklassesuburbia in hoofdstukken 2 en 3 van dit proefschrift het accent zal liggen op de wetenschappelijke traditie en in 4, 5 en 6 op de literaire, geldt steeds als uitgangspunt dat beide soorten teksten niet alleen binnen de eigen disciplinaire tradities verwijzen, maar ook over de grenzen tussen wetenschap en literatuur heen. In dit boek zal ik ze opvoeren als elkaars context. ${ }^{41}$ Een nuancering van bovenstaande opvattingen over tradities is daarbij op haar plaats. Dat teksten binnen een bepaalde traditie verwijzen, sluit geenszins uit dat ze zich verhouden tot teksten die we tot andere tradities rekenen. Dat betekent dat een bepaalde gedaante van de buitenwijk haar karakter kan ontlenen aan relaties met eerdere gedaanten uit meerdere tradities. Zoals ik hierboven liet zien, vallen kwesties in sociaal- en geesteswetenschappelijke betogen evenzeer aan te treffen in fictionele verhalen. Daarnaast keren vaak dezelfde thema's en motieven, associaties en opposities, symbolen en culturele narratieven - denk bijvoorbeeld aan het grote verhaal van de vooruitgang en dat van de American dream - in beide soorten teksten terug. Bovendien kan in een en dezelfde tekst sprake zijn van verkeer over de grens tussen de wetenschappelijke en literaire tradities heen. Zo zagen we dat invloedrijke sociologen als Whyte en Riesman romanpersonage Tom Rath opvoeren als de prototypische suburbanisant. Andersom is de rode draad in Karps roman Leave Me Alone een reeks kritisch-sociologische beschouwingen van een laffe, slappe middenklasse die zo uit een studie van Whyte, Riesman of C. Wright Mills had kunnen komen. En in Tom Wolfe's 
roman A Man in Full (1998), om een laatste voorbeeld te noemen, is het Joel Garreau's verhandeling Edge City (1991) die de schatrijke hoofdpersoon Charlie Croker ertoe brengt om aan de rand van Atlanta het megalomane Croker Concourse neer te zetten en daarmee zijn eigen graf te graven.

Tot slot zijn er teksten waarin grenzen tussen tradities zodanig worden overschreden, dat ze nauwelijks meer zijn in te delen. Zo is The Crack in the Picture Window niet eenvoudig te typeren als een roman. Aan de hoofdvertelling gaat een pleidooi vooraf waarin Keats zijn afkeer van de tracts in de jaren vijftig breed uitmeet. Van meet af aan is duidelijk dat het verhaal over de Drones een fictionele illustratie is ter ondersteuning van de ronkende retoriek waarmee Keats de buitenwijk van de lagere middenklasse te lijf gaat. Niet voor niets wordt John Drone in het laatste hoofdstuk als een "easy tool' terzijde geschoven. ${ }^{42}$ In dit licht is het niet verbazingwekkend dat Keats' vertelling zelden in literatuurwetenschappelijke beschouwingen opduikt, maar des te meer in suburbiastudies. En wat te denken van Douglas Couplands Generation $X$ en 'Brentwood Notebook' (1996) die ik in dit boek onder de loep zal nemen? We kunnen het eerste een roman noemen, maar hoe zit het met de populairsociologische terminologie in de marge van de hoofdvertelling en de statistieken waarmee het boek eindigt? Couplands notebook is nog lastiger in te delen. Het maakt deel uit van een uitermate heterogene bundel, samengesteld uit onder meer fictionele verhalen, essays, ansichtkaarten en een brief. Bovendien combineert het zelf verschillende genres, naast een verslag van observaties ter plaatse, onder andere reclameteksten, krantenartikelen, fragmenten uit memoires, foto's van beroemdheden, een sociaal-wetenschappelijke studie en zelfs een menukaart.

Of het nu gaat om dit soort hybriden of om traditionelere teksten, de stelling die in dit proefschrift wordt verdedigd, is dat in representaties van de middenklassebuitenwijk met de suburbane ruimte steeds een bepaalde levensstijl wordt opgevoerd en daarmee cen bepaalde temporele oriěntatic. Omdat met name deze laatste een centrale rol vervult in de verbeelding van de buitenwijk en haar middenklassebewoners, zal in mijn interpretatie de verbeelding van tijd op de voorgrond staan. Op zoek naar de constructie van bekende beelden en die van beelden die daarop variëren, staat voor- 
af niet vast in welke (soort) teksten we een eenzijdige representatie van suburbia aantreffen en in welke het subtieler gestalten krijgt. Steeds zullen we moeten vaststellen hoe we een bepaalde buitenwijk en haar bewoners precies aantreffen. We zullen ons moeten afvragen wat ervoor nodig is om hen juist op deze en niet op die manier tot uitdrukking te laten komen. 

2

Het consumptieparadijs

De robuuste verbeelding van suburbia 



\section{Inleiding}

De buitenwijk wordt beschouwd als de plaats bij uitstek waar grote groepen Amerikanen kunnen genieten van een comfortabel bestaan. Ze geldt als de ideale plek voor het goede leven. 'Suburbs,' schrijft John Stilgoe in zijn ontstaansgeschiedenis van de Amerikaanse buitenwijk, 'represent the good life, the life of the dream, the dream of happiness in a single-family house in an attractive, congenial community' (Stilgoe (1988): p. 2). Tegelijkertijd echter, staat suburbia te boek als een hazy half-world bevolkt door half-men en als een sociaal, cultureel en architectonisch wasteland. Het is een smet op de gebouwde omgeving en de omringende natuur, zo verwoordt Berger bijvoorbeeld het oordeel van critici-'a dreary blight on the American landscape, the epitome of American standardization and vulgarization, with its row upon monotonous row of mass produced cheerfulness masquerading as homes, whole agglomerations or 'scatterations' of them masquerading as communities' (Berger (1971a): p. 159). De buitenwijk oogst fraaie loftuitingen en bittere kritiek. Nadat ze zich in de loop van de negentiende eeuw heeft ontwikkeld tot een breed gedragen ideaal, geldt ze vanaf het midden van de twintigste niet meer alleen als droom, maar steeds nadrukkelijker ook als nachtmerrie.

In zowel de positieve als negatieve verbeelding van suburbia valt op dat er meer op het spel staat dan eenvoudig een plek even buiten de stad.Zeker vanaf de jaren vijftig is sprake van een polemiek waarin verdediging van suburbia een verdediging betekent van aloude Amerikaanse normen en waarden, terwijl een aanval kritiek inhoudt op de uit de hand gelopen consequenties van een aantal daarvan. Geograaf D.W. Meinig noemt suburbia een symbolisch landschap. Het maakt deel uit van de iconografie van de Amerikaanse natie, van een stelsel van waarden, herinneringen en gevoelens dat mensen bindt - en dat, zo wil ik daaraan toevoegen, de groep evengoed 
kan splijten. Ontstaan in de negentiende eeuw, schrijft Meinig, ontwikkelt het zich in de loop van de twintigste tot een standaard waaraan woonplaatsen en levensstijlen worden getoetst. Het komt symbool te staan voor niets minder dan 'the country's grass roots and the fountainhead of the American Way of Life' (Meinig (1979b): p. 172) ${ }^{43}$. Gaat het om suburbia, dan gaat het om de essentie van wat we onder 'Amerikaans' verstaan, concludeert Meinig.

Met deze gedachte staat hij allerminst alleen. In Robert Sterns architectuurhistorische Pride of Place (1986) geldt suburbia als de belichaming van 'American aspirations deeply rooted in the national psyche' (Stern (1986): p. 125). Het vrijstaande huis op een suburbaan perceel, betoogt Stern, is tot op de dag van vandaag het beeld van de Amerikaanse zoektocht naar een ideale gemeenschap in de natuur. Het belichaamt de droom van 'an attainable, inhabitable Arcadia in the form of a village, only a short ride from the city, where the American family can dwell in its individual house-temple' (ibid). Vergelijkbaar is de typering van stadshistorica Mary Corbin Sies. Nog steeds gaat van het suburbane ideaal een immense wervende kracht uit, schrijft ze. De droom is dan ook niet zomaar een droom. 'The single-family home with a garden and plenty of open space located in a homogeneous, locally controlled neighborhood on the outskirts of a city, betoogt Sies, 'has come to symbolize fulfillment of the American Dream itself' (Sies (2001): pp. 318-9).

Het is verleidelijk deze Amerikaanse droom te beschouwen als de droom van de Amerikaan. In het vorige hoofdstuk zagen we echter dat in het Westport van de Raths een heel specifieke Amerikaan woont. Greentree Avenue is de straat van een middenklasse die veiligstelt wat ze heeft bereikt en ondertussen droomt van meer. Het nationale ideaal blijkt een ideaal voor een deel van de natie. Zo is het in Fishmans Bourgeois Utopias uitdrukkelijk het moderne middenklassegezin dat de kans krijgt en grijpt om uit de stad te vertrekken. Het is dat gezin dat ervan droomt in harmonie met de natuur een welvarend en onafhankelijk leven te leiden en deel uit te maken van een beschermende, hechte en stabiele gemeenschap (zie Fishman (1987): p. x). Diezelfde notie komt tot uitdrukking in twee artikelen van Mary Sies in Journal of Urban History. Het suburbane ideaal, schrijft ze, is een 'enormously popular, enduringly succesful consensus about how middle-class North Americans might best organize 
their households and about the style of living to which hardworking families might aspire' (Sies (2001): p. 329, cursivering DH). In dat ideaal staat volgens Sies een stabiel gezins- en gemeenschapsleven centraal. Enerzijds betekent dit huiselijkheid en sociale harmonie tussen gelijkgestemde geesten. Anderzijds staat het garant voor de opvoeding van de ondernemende en hardwerkende individuen waarom een op concurrentie en prestatie gerichte economie vraagt. Het ideaal is een balans tussen gemeenschap en individualiteit, natuur en stedelijkheid, geloof in traditie en rationaliteit, gelijkgezindheid en streven naar status (zie Sies (1987): pp. 85-6).

Het gaat hier duidelijk niet slechts om ideeěn over de ligging en inrichting van een bepaalde plaats. Naast locatie en ontwerp ligt de nadruk op bepaalde waarden en normen als richtsnoer voor een levenswijze en gedrag. Zolang deze uitdrukking krijgen in prachtig gelegen buitenplaatsen wordt suburbia vrijwel zonder uitzondering geprezen. Naarmate de buitenwijk echter voor steeds grotere delen van de middenklasse toegankelijk wordt, komt ze steeds nadrukkelijker te boek te staan als probleem. Dat probleem wordt geformuleerd in nagenoeg dezelfde termen als de ooit zo schitterende suburbane droom. Alleen verschuift de betekenis die eraan wordt toegekend, of komt voor het ideaal een minteken te staan. Zo wordt autonomie egoìsme, harmonie conformisme en het streven naar status status anxiety. En zo slaat cultuur om in geestelijke armoe en individualiteit in een gebrek aan ondernemerschap. ${ }^{44}$ Hoewel deze waarderingen radicaal verschillen, zijn de overeenkomsten tussen de wijzen waarop ze uitdrukking krijgen opvallend. In zowel de positieve als negatieve verbeelding van de buitenwijk en haar bewoners kunnen we eenzelfde, beperkt narratief en thematisch repertoire onderscheiden.

Voordat we in hoofdstuk 3 concurrerende versies van suburbia onder de loep zullen nemen, wijs ik constanten aan die in de verbeelding van de buitenwijk en haar bewoners een grote rol spelen. Waar het in dit hoofdstuk om gaat, is de continuilteit die de representatie van suburbia kenmerkt. Ik onderscheid een aantal noties die steeds opnieuw opduiken en in belangrijke mate relaties tussen centrale elementen - zoals we hierboven zagen in elk geval de buitenwijk, de middenklasse en Amerika - helpen organiseren. De jaren vijftig staan centraal. In het beeld van dit decennium komen 
verschillende verhalen bijeen. Het wordt niet alleen opgevoerd als de bloeiperiode van suburbia, maar ook als de tijd van de zogeheten new middle class. Hoe de waardering ook uitvalt, het beeld van de buitenwijk smelt samen met dat van de middenklasse. De verbeelding van de fifties-suburb blijkt bovendien nog op een andere manier gelaagd. Ze herneemt noties die niet alleen het suburbiadiscours beheersen, maar ook een belangrijke rol spelen in het denken over de Amerikaanse samenleving en cultuur in het algemeen. Achtereenvolgens bespreek ik het paradijs, de pastorale, het pittoreske, de frontier en de stad. Net als de buitenwijk uit de jaren vijftig vormen zij terugkerende motieven die in uiteenlopende teksten bijdragen aan de verbeelding van suburbia en zijn bewoners. In dit hoofdstuk gaat het om hoe zij daaraan bijdragen. De centrale vraag is wat ze precies doen in een aantal belangrijke teksten uit het suburbiadiscours. 


\section{De fifties-suburb}

\subsection{Plaats-en tijdbeeld}

De verbeelding van de buitenwijk is er een vol verwachtingen en teleurstellingen, dromen en doemscenario's, niet alleen wat betreft de vormgeving van wijken en woonhuizen. Ook als het gaat om levensstijl en bejubelde dan wel verafschuwde karaktereigenschappen worden beladen termen van stal gehaald en worden grote verhalen verteld. Dat geldt in het bijzonder voor het suburbia van de jaren vijftig. De fifties-suburb geldt als niets minder dan een gerealiseerd Utopia, Newtopia, Subtopia en Autopia, maar evenzeer als the hidden underbelly of modernity, niet iets om trots op te zijn, maar om je voor te schamen.

Om op dit soort kwalificaties greep te krijgen, wil ik, in aangepaste vorm, twee concepten gebruiken uit Rob Shields' Places on the Margin (1991). Shields - die zelf niet ingaat op buitenwijken - stelt dat een plaats nooit zomaar een plaats is. We kunnen spreken van een fysieke plek waar mensen wonen en die we als toerist of onderzoeker kunnen bezoeken; begrijpen doen we zo'n plaats in veel complexer termen. Als we de gebouwde omgeving betekenis geven, mobiliseren we niet alleen kennis, maar ook waarden, normen en gevoelens. Niet alleen wat we weten bepaalt hoe we de plek opvatten, evengoed wat we vinden en voelen. Shields spreekt van een imaginary geography, een heterogeen ensemble waarin een plek niet zomaar een plaatsaanduiding in de geografische ruimte is, maar altijd al is overladen met duidingen en waarderingen. ${ }^{45}$ In zo'n verbeelde geografie krijgen in de loop der tijd bepaalde place images gestalte, beelden waarin een plek functioneert in bepaalde associaties en opposities, waarin ze een symbolische rol kan komen te vervullen en waarin ze een bepaald imago kan krijgen waarvan ze niet eenvoudig afkomt. ${ }^{46}$ Sommige van deze plaatsbeelden zijn vluch- 
tig. De wijzen waarop de plek erin wordt voorgesteld, houden niet lang genoeg stand om gemeengoed te worden. Andere, daarentegen, zoals het beeld van de fifties-suburb, worden gedurende langere tijd keer op keer gereproduceerd. Ze blijken verleidelijk genoeg om steeds opnieuw in de verbeelde geografie - in dit geval die van suburbia - te worden ingezet. ${ }^{47} \mathrm{Ze}$ laten zich daarin onderscheiden als een groep constanten, beelden die te midden van tal van veranderingen in het denken over de buitenwijk continuiteit opleveren.

Die continuiteit is niet terug te voeren op een bepaalde verbeelding van de suburbane ruimte alleen. Waar het hierboven ging over de realisatie van een (nationaal) ideaal of juist de mislukking daarvan, bleken met name bepaalde opvattingen over gemeenschapsleven en de houding en het gedrag van het individu relevant. Het ging bijvoorbeeld om geborgenheid en vrijheid, harmonie en onafhankelijkheid en het belang van traditie en het verlangen naar verbetering van de sociale positie. In de buitenwijk zou stabiliteit worden nagestreefd, maar ook vooruitgang. Er zou rust heersen, terwijl tegelijkertijd om statusverhoging zou worden gewedijverd. In de suburb zou, met andere woorden, een bepaalde levenswijze gestalte krijgen en daarmee een bepaald tijdperspectief. Buitenwijkbewoners zouden op een bepaalde manier terugblikken en vooruitkijken. Shields' plaatsbeeld is zodoende evenzeer een tijdbeeld. ${ }^{48}$ In suburbia's verbeelde geografie spelen waarderingen van toen, nu en straks een grote rol en zijn temporele categorieèn als verleden, heden en toekomst niet minder emotioneel en ideologisch geladen dan ruimtelijke. Waar Shields zich concentreert op de rol van hardnekkige representaties van plaats en ruimte in de formatie van beelden en verhalen die zich niet eenvoudig laten vervangen, interesseert mij hoe met de verbeelding van de buitenwijk als plek tevens een verbeelding van suburbane tijd gestalte krijgt. Het is met name de temporele oriëntatie die bijdraagt aan de continuilteit in de representatie van de buitenwijk en haar bewoners.

\subsection{De true site of middleAmerica}

Twee woorden schieten Betsy Rath te binnen als ze het bestaan aan Greentree Avenue tracht te typeren: 'dull' en 'frantic'(Wilson(1956): 
p. 121), saai en tegelijkertijd een beetje paniekerig. De middenklasse in het beeld dat, in Baldassare's formulering uit hoofdstuk 1, in Amerika's collectieve geheugen staat gegrift, toont zich tevreden met een rustig leven in een veilige, misschien wat saaie suburb en streeft ondertussen naar aanschaf van een luxere wagen en een grotere woning.

Deze buitenwijk en deze middenklasse duiken in vrijwel elke tekst over suburbia op. De fifties-suburb wordt er opgevoerd als wat wel de true site of middle America wordt genoemd. In deze notie komen drie beelden bijeen. Het eerste is een traditioneel beeld dat zoiets als het ideale Amerikaanse karakter tot uitdrukking brengt. Het tweede is een karakterisering van de zogenoemde nieuwe middenklasse. Het derde schetst het suburbia dat in de periode voor en na de Tweede Wereldoorlog gestalte krijgt. Hoewel in elk hiervan een ander onderwerp centraal staat, wordt steeds eenzelfde verhaal verteld. In alledrie krijgt eenzelfde levensvisie gestalte, georganiseerd rond een bepaalde opvatting over hoe te handelen en een bepaalde temporele oriëntatic.

\subsection{De ideale Amerikaan}

In typeringen van het leven in de buitenwijk is de 'Frans-Engelse Amerikaan' Hector St. John de Crèvecoeur een terugkerende figuur. Niet omdat hij bekend staat als een beroemd suburbanisant, noch omdat hij zich heeft uitgelaten over het leven in suburbia - in het achttiende-eeuwse Amerika kan van buitenwijken immers nog nict worden gesproken. Nee, Crèvecoeur wordt opgevoerd als een scherp observator van zoiets als een typisch Amerikaans karakter. Als buitenstaander - Crèvecoeur doet eind achttiende eeuw Amerika aan - valt hem op dat de Amerikaan houdt van het nieuwe en grote waarde hecht aan de vrijheid van bewegen. Deze vrijheid is in zijn ogen noodzakelijk om doelen te realiseren, doelen die hij eerst zelf formuleert en vervolgens individueel tracht na te streven. In Amerika, schrijft Crèvecoeur, heerst een sterke competitiedrang. Men wil slagen en is bereid voor succes te knokken. ${ }^{49}$

Bovendien, voegt hij toe, verlangt de Amerikaan naar een eenvoudig bestaan in een natuurlijke omgeving. Niet alleen om op een 
nog onbekend continent steeds opnieuw grenzen te slechten, zoals de prototypische sturdy yeoman, maar evenzeer om zich te wijden aan het in cultuur brengen ervan. Deze tweede bezigheid is die van de al even prototypische gentleman farmer, Jeffersons versie van de model-Amerikaan. Ook deze wil op eigen kracht op het platteland zijn dromen verwezenlijken, maar hecht daarbij uitdrukkelijk waarde aan zijn rol in de gemeenschap waarvan hij deel uitmaakt. Naast autonomic zijn rust en harmonie voorwaarden waaraan het ideale Amerikaanse bestaan moet voldoen.

Een zekere spanning kan de waarden die aan een dergelijk bestaan ten grondslag liggen, niet worden ontzegd. Individualiteit en onafhankelijkheid worden gepaard aan gemeenschap, een streven naar vernieuwing aan een behoefte aan stabiliteit. ${ }^{50}$ Toch is het precies deze combinatie die ook de negentiende-eeuwse ontwerper en architectuurcriticus Andrew Jackson Downing typisch Amerikaans acht. In een editorial voor The Horticulturist in 1847 stelt hij dat men geen filosoof hoeft te zijn om een van de meest opvallende nationale kenmerken van de Verenigde Staten op te merken. Hij heeft het over de 'spirit of unrest' die de Amerikaan ertoe brengt onbewoond gebied in te trekken. Maar dat is niet alles, Downing voegt daaraan nog een observatie toe. Hoe onrustig ook, Amerikanen lijken op niets zo verzot als 'to settle'. Beide neigingen maken volgens Downing deel uit van dezelfde frontier-traditie ${ }^{51}$, waarbij hij aantekent dat het verlangen 'to settle down' met de dag sterker wordt. ${ }^{52}$ Met name aan de oostkust ziet hij de Amerikaanse liefde voor verandering zich geleidelijk ontwikkelen tot een al even Amerikaanse liefde voor het leven thuis.

\subsection{De nieuwe middenklasse}

Eenzelfde combinatie van huiselijke rust en publiekelijk presteren en streven naar succes kenmerkt in geschiedschrijvingen van de suburb het beeld van de new middle class. Deze nieuwe middenklasse, die in de jaren vijftig massaal de buitenwijk opzoekt, verschijnt daarin niet uit het niets. In het laatste kwart van de negentiende eeuw wordt vaak een groep onderscheiden die snel in omvang toeneemt en die bovendien in het economische en maatschappelijke 
leven steeds invloedrijker wordt. Mary Sies spreekt in 'The City Transformed' (1987) van een Professional-Managerial Class. ${ }^{53} \mathrm{Ze}$ verdient haar brood in de zakenwereld, als arts, advocaat, architect en ingenieur, of in het onderwijs, de kunsten, de media of reclame. Behalve dit soort beroepen en bijbehorende salarissen delen de leden van deze klasse volgens Sies opvattingen en levensstijl. Ze spreekt van een waardesysteem waarin 'traditionele' huiselijkheid, sociale stabiliteit, matigheid en deugdelijkheid gepaard wordt aan een geloof in 'moderne' waarden als rationaliteit, efficiency, initiatief, autonomie, concurrentic en prestatic (zie Sies (1987): pp. 85-6).

Waar in Sies' geschiedenis de aandacht voornamelijk uitgaat naar de wijze waarop deze klasse haar ideeèn vertaalt in een geschikt woonoord voor de eigen groep, concentreert Margaret Crawford zich in Building the Workingman's Paradise (1995) op de manier waarop de nieuwe middenklasse haar waarden en normen tracht over te dragen op de arbeider door diens woonomgeving vorm te geven. Crawford voert een klasse op die vreest ondanks haar groeiende omvang niet het hoofd te kunnen bieden aan sociale onrust. Hoewel ze in het maatschappelijk leven steeds belangrijker functies vervult - in de verkoop, de techniek, de ambtenarij of de welzijnssector -, is ze bang het slachtoffer te worden van conflicten tussen grote, machtige ondernemingen en militante arbeidersorganisaties. In het eerste kwart van de twintigste eeuw zet ze zich daarom in toenemende mate in voor een stabiele, ordelijke en harmonieuze samenleving. Aanvankelijk vooral uit religieuze overtuiging en medemenselijkheid, later steeds professioneler en op basis van wetenschappelijk-rationele gronden richt ze zich op verbetering van het lot van de arbeider. Dit gebeurt onder meer door middel van de vormgeving van de plaats waar arbeiders, grenzend aan een fabrieksterrein, onderdak krijgen. Samen met welzijnswerkers, ontwerpers en landschapsarchitecten realiseren grote ondernemers wat Crawford de new company town noemt. De gedachte is dat beheersing van de omstandigheden controle betekent over het soort individu dat zich ontwikkelt. Van een woonomgeving waarin niets aan het toeval wordt overgelaten, zou een beschavende werking uitgaan.

De benodigde omgeving typeert Crawford als een semi-rurale, pittoreske plaats die de sfeer ademt van traditie, sociale harmonie en huiselijkheid. Er wordt een illusie gewekt, schrijft Crawford, van 
een onveranderlijke, preïndustriële orde. Het individu dat hierin tot bloei moet komen, is niet alleen lid van een stabiel gezin, maar dient zich bovenal te ontwikkelen tot iemand die op basis van ijver en ambitie een productief leven leidt. Bovendien zal het gaandeweg leren zelf richting te geven aan de eigen ontwikkeling. Heeft de arbeider zich de nodige middenklassewaarden eigen gemaakt, dan kan hij functioneren als Crèvecoeurs verlichte individu. Hij geldt dan als een zelfstandig en handelingsbekwaam subject dat in staat is doelen te formuleren, deze na te streven en uiteindelijk te verwezenlijken.

Deze middenklasse gelooft in de mogelijkheid vooruitgang te boeken, zowel in moreel als sociaal-economisch en materieel opzicht, maar legt hiervoor de basis in een omgeving die een uitermate behoudende sfeer ademt. Voor progressie in de toekomst zoekt de middenklasse houvast in een stabiliteit ontleend aan cen geìdealiseerd verleden. ${ }^{54}$ Datzelfde wordt gezegd van leden van de nieuwe middenklasse die zich minder dan die in Sies' en Crawfords studies expliciet uitspreken over hun idealen. Het gaat dản om een groerend aantal kantoorklerken met administratieve taken in grote overheidsorganisaties en in de groeiende dienstensector. Veelal worden ze opgevoerd als een gezichtloos middenkader, een in grijs flanel geklede massa mannen die dagelijks heen en weer forenst tussen stad en nieuwe buitenwijk. Dit beeld, waarin de groep zich onderscheidt van de geslaagde zakenman en de arbeider, komt over het algemeen tot stand in contrast met wat de 'oude middenklasse' wordt genoemd. Daarmee wordt gedoeld op de negentiende-eeuwse zelfstandige winkelier, ambachtsman en handelaar. Waar voor deze kleine ondernemers met name vrijheid en autonomie belangrijk waren, zo wordt betoogd, daar hecht de nieuwe witteboordenwerknemer aan de zekerheid van een positie binnen een grote organisatie. Vooruitkijken betekent voor hem een bescheiden verwachting te stijgen in de bedrijfshiërarchie. Geen grote sprongen voorwaarts, maar inspelen op mogelijkheden wanneer die zich voordoen. Van primair belang is echter een stabiele thuissituatie. Een traditioneel, ordelijk gezinsleven dient als thuishaven en als uitvalsbasis voor een carrière waarmee hoogstens een gemiddeld salaris wordt verdiend, voldoende voor cen middelgrote woning en een middenklasseauto. 
Dit beeld wordt minder homogeen als op deze klasse wordt ingezoomd. Er blijft sprake van een gerichtheid op harmonie, stabiliteit en zekerheid enerzijds en anderzijds onafhankelijkheid, initiatief en vooruitgang. Het verschil is dat deze orièntaties worden toegeschreven aan twee subgroepen. De wijdverbreide notie van middentwintigste-eeuws Amerika als een middle-class society roept meer vragen op dan ze beantwoordt, stelt een aantal invloedrijke sociologen in de jaren zestig. Met name Berger en Dobriner betogen dat de bovenstaande schets van de middenklasse te grof is. We dienen (op zijn minst) twee middenklassen te onderscheiden. Dat onderscheid houdt niet zozeer een economische stratificatie in, als wel een sociale. Door een aanhoudende stijging van de welvaart en een veranderde inkomensverdeling, betoogt Berger bijvoorbeeld in Working-Class Suburb (1960), werken economische criteria onvoldoende onderscheidend. In een samenleving waarin een redelijk opgeleide fabrieksarbeider vaak nauwelijks minder verdient dan iemand met een bescheiden kantoorbaan en kan beschikken over een eigen huis en twee auto s̀ iaten sociaie verschilllen zichi beter uitdrukken in termen van levensstijl. Berger schetst twee beelden. In het ene zien we een tevreden gezin rond de tafel zitten. Voor dit gezin is 'respectability' bijzonder belangrijk. Dit is het beeld, betoogt Berger, van de oude middenklasse - van de negentiende-eeuwse shoestring entrepreneur en bovendien van wat in de jaren vijftig en zestig wordt aangeduid als de 'lagere middenklasse'. Door te spreken van zo'n lower-middle class kunnen we een upper-middle class onderscheiden, schrijft Berger, waarbij deze laatste term wordt gebruikt als synoniem voor de groeiende new middle class. Het beeld van deze nieuwe middenklasse is dat van de cocktailparty, eventueel zelfs van de country club, en bovenal van een hypergevoeligheid voor statusverschillen (zie Berger(1968): pp. 93-5).

In Class in Suburbia (1963) karakteriseert Dobriner het bestaan van de lagere middenklasse als 'secure, unexciting and comfortable' (Dobriner (1963): p. 47). Het is het leven van solid citizens die wellicht dromen van een luxer bestaan, maar die zich voornamelijk tevreden tonen met wat ze hebben en hoogstwaarschijnlijk zullen houden. Wat de nieuwe, hogere middenklasse typeert, daarentegen, is carrière, succes en het streven naar een hogere status (zie ibid: pp. 41-4, 48). Niet 'decency', maar smaak en stijl - liefst de nieuwste stijl - 
staan centraal. Daarmee kan men publiekelijk laten zien bij wie men hoort, bij wie men wil horen en vooral ook bij wie niet. Het streven naar status en het verlangen naar sociale mobiliteit worden opgevoerd als de onderscheidende kenmerken van de levensstijl van deze nieuwe, hogere middenklasse. Met name in Bergers betoog gebeurt dit expliciet in termen van temporele oriëntatie. De lagere middenklasse kunnen we volgens hem nauwelijks onderscheiden van de hogere arbeidersklasse. Hij beschouwt deze als één sociale laag, de middle-class working class. 55 Wat haar onderscheidt van de nieuwe, hogere middenklasse is niet zozeer het inkomen en de vrijstaande suburbane woning, maar 'the mantle of mobility' (Berger (1968): p. 96):

their style is a terminal one; they live in the present, mostly in the style that they have always lived (...). [But] the element of social mobility is missing; aspiration and anticipation are things for educated people with a fluid position in an organizational hierarchy, and it is this that makes suburban domesticity in a \$12,00o house a final fulfillment(ibid: pp. 97,98).

In 'The Myth of Suburbia' varieert Berger op deze formulering. Aan 'aspiration and anticipation' voegt hij onder andere 'status anxiety' toe (zie Berger (1971a): pp. 163-4). Wat de nieuwe middenklasse onderscheidt, is haar betrokkenheid op de toekomst. Een verwachting van en een streven naar sociaal-economische vooruitgang is de norm. Nu gaat het goed, straks, zo is het verlangen, zal het beter gaan.

Een concrete illustratie van dit beeld is het portret van deze nieuwe middenklasse in Seeley, Sim en Loosley's klassieke Crestwood Heights (1956). Haar typerende eigenschappen zijn die van de manager: handelen staat hoger aangeschreven dan contemplatie, calculatie wint het van intuïtie en bovendien worden voorspellen en beheersen hoog gewaardeerd. Het gaat om de leden van een 'futureoriented, voluntaristic, individualistic, control-aspirant, rationalizing, organizing' middenklasse(Seeley, Sim en Loosley (1956): p. 359). De berusting van de arbeidersklasse is haar vreemd, zo wordt betoogd. Hetzelfde geldt voor de zekerheid van de upper class. Crestwood Heights' middenklasse oriënteert zich voortdurend op de toekomst, op carrière in het eigen leven en op een verdere stijging van status in 
dat van de kinderen. 'Success', 'doing well' en 'getting ahead' zijn de sleutelbegrippen. Wat is bereikt, dient te worden veiliggesteld, maar zo gauw een ingenomen positie voldoende stabiel is, ontstaat de ambitic om hogerop te komen. De gerealiseerde status is 'a mere stepping-stone, a pied-d-terre, a precarious resting point, in a vertical movement, in which upward hopes and downward fears have, and are felt to have, a very high probality of realization'(ibid: p. 356).

\subsection{De nieuwe buitenwijk}

Het derde beeld dat achter de notie van de true site of middle America schuilgaat, betreft de nieuwe buitenwijk. De jaren vijftig worden algemeen beschouwd als de periode waarin de middenklasse het tij mee heeft. In een tijd van toenemende welvaart en lage inflatie geniet zij financiêle zekerheid. Bovendien wordt voor een groeiend deel van haar leden verbetering van de sociaal-economische positic een realistische verwachting. De naoorlogse buitenwijk geldt als de plaats waar zowel stabiliteit als vooruitgang sterker dan waar ook tot uitdrukking komen. In een steeds onpersoonlijker en competitiever maatschappelijk leven biedt ze het gezin een beschermde woonomgeving. Het idee is dat de eigen woning als bastion fungeert. Het leven thuis kan daarbinnen functioneren als 'a kind of anchor in the heavy seas of urban life', schrijft Jackson bijvoorbeeld (Jackson (1987): p. 50). Daarnaast zou de vooruitgangsgedachte die in de jaren vijftig zowel op het gebied van technologie, economie als welzijn hoogtij viert in de buitenwijk fysieke gestalte krijgen. Nieuwe huizen, frisse gazonnetjes en jonge boompjes symboliseren een nieuw tijdperk. In een periode waarin bovendien consumptie de nieuwe volkssport wordt, zijn er mogelijkheden te over om zelfs de geringste onderlinge statusverschillen publiekelijk tot uitdrukking te brengen.

De gedachte is dat de Amerikaanse droom bij uitstek kan worden gerealiseerd in de buitenwijk. Die droom staat voor succes als beloning voor hard werken, status als resultaat van eigen presteren en comfortabel wonen als toonbeeld van wat is bereikt - het goede leven, kortom, in Amerikaans perspectief. 'Suburbia,' schrijft Baldassare bijvoorbeeld, 'in a sense, was the Shangri-la, the heart of 
these exhilarating dreams of post-World War 11 America' (Baldassare (1986): p. 47). Het doel in die jaren is, in termen van Stephanie Coontz, 'to achieve the house in the suburbs that was an integral part of the postwar American dream' (Coontz (1992): p. 264). Het is de vrijstaande eengezinswoning in deze omgeving, schrijft Gwendolyn Wright, die geldt als 'the quintessential expression of that dream'(Wright(1993): p. 267) ${ }^{56}$

De buitenwijk wordt in dit verband vaak opgevat als de woonplaats voor een betrekkelijk homogene middenklasse. In veel gevallen gaat de aandacht uit naar de vrijstaande, maar niettemin geprefabriceerde woningen in de vele tract developments die in de jaren vijftig big business zijn. Deze grootschalige projecten bieden, zeker in de beginjaren, ruimte aan een bevolking die eenzelfde positie inneemt op de sociaal-economische ladder. De sociale druk die van zo'n groep zou uitgaan, is in veel teksten die aan de tract zijn gewijd een centraal thema. Status anxiety staat in dit geval voor een bijna obsessief streven naar behoud van de sociale status in de wijk. Wie deel wil uitmaken van de groep contormeert zich aan de heersende opvattingen, smaak en stijl en zorgt er bovendien voor dat nieuwkomers in het bestaande plaatje passen. Afwijkende levenswijzen worden geweerd, gelijkgezinden worden uitgenodigd voor party na party. Op deze manier, zo is de gedachte, blijft de gemeenschap een homogeen geheel. ${ }^{57}$ Hoewel er wel degelijk sprake is van verloop, kan de status-quo zoveel mogelijk worden gehandhaafd. ${ }^{58}$

In dit beeld wordt de buitenwijk neergezet als de geschikte omgeving om publiekelijk te laten zien wat is bereikt. De inrichting van de wijk en vooral de grootte en stijl van de huizen - en niet te vergeten de kwaliteit van het gazon - worden opgevat als toonbeeld van de positie die bewoners hebben gerealiseerd. Zo presenteert Kenneth Jackson, bijvoorbeeld, de suburbane eengezinswoning als het zichtbaarste symbool van having arrived at a fixed place in society' (Jackson (1987): p. 50). Ook aan de decoratie van het huis wordt een belangrijke symbolische functie toegeschreven. De vaak historiserende verfraaiingen die bewoners aanbrengen, worden gelezen als uitdrukking van een geloof in zekerheid en stabiliteit. Bovendien spelen consumptieartikelen een hoofdrol. Om deel uit te maken van de groep wordt bezit van een auto als vereiste gezien, evenals de beschikking over bepaalde apparaten binnenshuis, zoals 
telefoon, televisietoestel en wasmachine. Voor de aanschaf van dergelijke producten om zich te verzekeren van lidmaatschap van de groep is zelfs een term gemunt: socioloog Harry Henderson spreekt van approval insurance.

In een breder perspectief wordt diezelfde fifties-buitenwijk van een plaats voor verzekering een plek voor vooruitgang. In teksten waarin dit suburbia wordt opgevoerd, is het uitgangspunt niet zozeer de afzonderlijke buitenwijk, maar meestal de suburbane omgeving als geheel. Er wordt gedacht in termen van een mozaïek in Peter Mullers Contemporary Suburban America (1981) zelfs een balkanisering - van suburbs. Elke gemeenschap heeft daarin een eigen sociaal-economische status. In een decennium waarin collectief optimisme wordt vertaald naar een geloof in de mogelijkheid vooruitgang te boeken in het individuele leven spelen de verschillen tussen die gemeenschappen een belangrijke rol. Zij stellen het suburbane middenklassegezin in staat verticale mobiliteit zichtbaar te maken als horizontale, geografische mobiliteit. Een bescheiden salarisverhoging wordt vertaald in aanpassingen in en rond het huis. Promotie of een beter betaalde baan bij een ander bedrijf betekent idealiter verhuizen naar een betere buurt - ruimer ingericht, met grotere woningen en een hoger aanzien.

Ook in dit beeld spelen consumptiegoederen een grote rol. Vaak wordt geredeneerd in termen van Thorstein Veblens beroemde conspicuous consumption, waarmee de nadruk komt te liggen op de sociaal-culturele betekenis van consumptie in het algemeen en opwaartse sociale mobiliteit in het bijzonder. ${ }^{59} \mathrm{De}$ gedachte is dat consumptieartikelen niet alleen bijdragen aan de sociale cohesie in een groep, maar evenzeer fungeren als middelen ter onderscheiding van de leden onderling. ${ }^{60}$ Niet het bezit van een tv-toestel als zodanig is nu van belang, maar het specifieke type dat wordt aangeschaft. Zoals ook de precieze stijl van het nieuwe bankstel nauw luistert. Het zijn de details in materiaalkeuze en vormgeving die de kleine, maar zo belangrijke verschillen in levensstijl communiceren.

Juist de buitenwijk, zo is de gedachte, leent zich voor opzichtige consumptie. Misschien kopen suburbanisanten niet veel meer dan stedelingen, maar wat ze kopen is in hun omgeving extreem zichtbaar. Dobriner spreekt van het visibility principle, een kenmerk van de suburbane ruimte dat garandeert dat dingen worden gezien (zie 
Dobriner (1963): pp. 9-11). Twee van die dingen krijgen vaak bijzondere aandacht. De zogeheten picture window - die de façade van veel suburbane woningen domineert - wordt beschouwd als etalage. De suggestie is dat het grote raam reclame maakt voor de objecten binnenshuis. 'Here it is, the picture window proclaims, our modest little home - but see the new couch or the new lamp' (Donaldson (1969): p. 75). ${ }^{61}$ Zie vooral ook de auto, valt vaak te lezen. Geen beter symbool voor succes dan juist dit en vooral niet dat merk, bouwjaar en type. Geen betere uitdrukking van individuele identiteit, bovendien, dan op de oprit een 'sleek, air-conditioned, high-powered, personal statement on wheels', zoals Jackson (Jackson (1987): p. 246) het uitdrukt.

\subsection{Drie in één}

We kunnen de jaren vijftig beschouwen als een motief dat in talloze teksten de suburb voorstelt als de true site of middle America. Het brengt twee belangrijke maatschappelijke ontwikkelingen - de opkomst van een nieuwe middenklasse en de ongekend snelle uitbreiding van suburbia - in één beeld onder. Bovendien worden beide nauw verbonden met een aantal traditionele Amerikaanse idealen. Naast een prototypisch Amerikaans subject maken belangrijke culturele narratieven over een harmonieus gezins- en gemeenschapsleven, sociaal-economisch opwaartse mobiliteit, materiële vooruitgang en de American dream het beeld compleet.

Deze drie beelden maken de notie van de suburb als de true site of middle America tot meer dan een beeld van een bepaalde plaats. Met een plek krijgt een temporele oriëntatie gestalte. Er komt een plaats- en tijdbeeld tot stand dat is georganiseerd rond de bijzondere combinatie van rust en beweging, traditie en ambitie, behoud en vooruitgang. De buitenwijk wordt beschouwd als de plek die bij uitstek geschikt is als een duurzaam thuis voor een rusteloos volk. ${ }^{62}$ Of ze nu worden ingelost of juist niet - zoals we in hoofdstuk 3 zullen zien, lopen de meningen daarover sterk uiteen -, het suburbia van de jaren vijftig staat in dit opzicht voor hoge verwachtingen. De suggestie is dat in de jaren vijftig als nooit tevoren het ideale Amerikaanse karakter tot zijn recht kan komen. Niets zou onafhankelijk- 
heid en gemeenschapszin, de 'spirit of unrest' en het verlangen 'to settle' in de weg staan. In een decennium waarin ze het tij mee heeft, is het de nieuwe middenklasse die Crèvecoeurs tamelijk a-historische nationale ideaal dient te actualiseren. Met als uitvalsbasis een traditioneel, stabiel gezinsleven kan de forens, zonder op het spel te zetten wat reeds is gerealiseerd, een hogere positie nastreven op de sociaal-economische ladder. In suburbia kan wat is bereikt, worden veiliggesteld, terwijl tegelijkertijd subtiele statusverschillen publiekelijk kunnen worden getoond. Voor wie bovendien een grotere sprong voorwaarts heeft gemaakt, zijn er mogelijkheden te over om te verhuizen naar een ruimere woning in een nog comfortabeler buitenwijk. In suburbia kan het autonome individu in een gemeenschap van gelijkgezinden laten zien waartoe het in staat is. Daar, beter dan waar ook, zou het gestalte kunnen geven aan het ideaal van thuis zijn $e n$ vertrekken, tevreden terugblikken $e n$ ambitieus vooruitkijken. 


\section{Vijf traditionele culturele noties}

Al een halve eeuw houdt dit beeld van de fifties-suburb hardnekkig stand. Naast de driehoeksverhouding tussen buitenwijk, middenklasse en de ideale Amerikaan en de verstrengeling van grote verhalen over gezin, materie̋le vooruitgang en opwaartse mobiliteit dragen hieraan culturele ideeèn bij die niet alleen in het denken over suburbia, maar ook over Amerika als geheel een lange staat van dienst hebben. Hoewel ze niet altijd expliciet worden benoemd en daardoor niet altijd even gemakkelijk herkenbaar zijn, hoewel ze vaak in combinatic voorkomen en soms zelfs als varianten van elkaar opduiken, zal ik vijf motieven onderscheiden. Achtereenvolgens zullen het paradijs, de pastorale, het pittoreske, de frontier en de stad de revue passeren. ${ }^{63}$ Deze noties overlappen gedeeltelijk, maar verschillen ook. Ze wortelen in verschillende culturele tradities. Een deel van de robuustheid van de hierboven geschetste verbeelding van de buitenwijk berust, zo lijkt het, op het feit dat het beeld vanuit zulke verschillende tradities wordt gevoed. Wie bijvoorbeeld niet in het paradijs gelooft, kan altijd nog vallen voor de pastorale en het pittoreske. Elk van de vijf brengt een specifiek verband tussen een bepaalde ruimte, de identiteit van bewoners en hun temporele perspectief naar voren. Gezamenlijk vormen ze een voorraad plaats- en tijdbeelden waarin zowel harmonie als onafhankelijkheid, rust als vooruitgang, terugblikken als vooruitkijken beschikbaar zijn. Afhankelijk van de specifieke gedaante van de buitenwijk worden hieruit verschillende beelden, en verschillende combinaties daarvan, geput. 
In Making a Middle Landscape (1991) schrijft Peter Rowe dat opvattingen over de organisatie van de gebouwde omgeving en de regels voor ons gedrag daarin, het niet kunnen stellen zonder zedenpreken, verhalen, metaforen en mythen (zie Rowe (1991): p. 217). We ontlenen daaraan verklaringen en rechtvaardigingen en zetten ze in om teleurstellingen in de praktijk te verwerken of weg te werken. Wat betreft de buitenwijk speelt het paradijs een hoofdrol. Vanaf het einde van de achttiende eeuw tot op de dag van vandaag wordt suburbia gepresenteerd als een paradijs op aarde, een harmonicuze hof waarin volmaakte rust heerst.

In de meeste geschiedenissen vindt de buitenwijk haar oorsprong eind achttiende eeuw rond industrialiserende steden als Londen en Manchester. De gegoede burgerij vindt de stad te vol en de lucht te vuil. Zij besluit zich terug te trekken in woningen buiten de stad. Vaak wordt benadrukt dat dit besluit wordt bespoedigd door een ideaal dat in die jaren steeds populairder wordt bij de bourgeois: een gezinsleven zoveel mogelijk in afzondering van de buitenwereld. Het gesloten kerngezin komt op, zo wordt verteld, met daarin besloten een emotionele band tussen gezinsleden, toenemende intimiteit en een groeiende aandacht voor de opvoeding van kinderen. Pleitbezorgers worden gezocht in een evangelische beweging die in de Engelse burgerij veel aanhangers heeft. $\mathrm{Zij}$ achten de stad een bolwerk van immoraliteit. Tegen de chaos, het gevaar en het zondige gedrag in die stad moet het gezin, dat zij als een heilig instituut beschouwen, worden beschermd. Het dient fysiek afstand te houden. Het gezin is pas thuis als het wordt omringd door de natuur. Het ideaal van de evangelisten is een deugdelijk gezinsleven in een paradijselijke tuin. Preken en publicaties van voormannen als William Wilberforce en Henry Thornton worden aangehaald om te benadrukken hoe belangrijk deze omgeving is. Zij verklaren heilig wat de emotionele banden binnen het gezin versterkt en vervloeken wat het gezin en daarmee de moraliteit in gevaar brengt. Robert Fishman citeert in Bourgeois Utopias William Cowper, die het ideaal verwoordt als 'Domestic happiness, thou only bliss. Of Paradise that hast survived the fall!' (Fishman (1987): p. 54$){ }^{64}$ 
Als voorbeeld van een omgeving waarin leden van de evangelische beweging een deugdelijk gezinsleven mogelijk achten, wordt vaak Clapham opgevoerd, een van de eerste suburbs even buiten Londen. Fishman introduceert het bijvoorbeeld als een 'all encompassing park, an Edenic garden that surrounded the houses and made sweet the life of the families within them' (ibid: p. 55). In dit rustige, groene woonoord, betoogt hij, realiseren deze gezinnen hun aardse ideaal. Bovendien, voegt hij toe, biedt het de beste garantie voor geluk in het leven na de dood. Omdat het gezinsleven ${ }^{65}$ gevrijwaard blijft van de verlokkingen in de profane, zondige grote stad, kan thuis de heilzame morele sfeer totstandkomen die een voorwaarde is voor een streven naar eeuwig geluk. De essentie van het suburbane ideaal - de scheiding tussen wonen en werken -, betoogt Fishman, moeten we begrijpen in het kader van dit verlangen naar verlossing. ${ }^{66}$ Dat is volgens John Stilgoe diepgeworteld. Het ideaal, zo vat hij samen, is 'family salvation through residence in natural beauty' (Stilgoe (1988): p. 55). Wonen in de buitenwijk betekent in deze opvatting niet alleen ruim wonen in een mooie omgeving, maar bovenal wonen in een staat van rust en regelmaat, die bovendien uiteindelijk moet uitmonden in de voldoening van een eeuwig volmaakte eindtoestand.

Het paradijselijke motief dat de eerste ideologen in het denken over suburbia introduceren, blijkt een blijvertje. In talloze teksten duikt het in meer of minder expliciete gestalten op. In een toeristische gids uit 1857 worden bijvoorbeeld de buitenwijken van Manchester lyrisch beschreven als

long vistas of enchanting villas, in the most attractive architecture ornamented in front with spacious gardens, grass plots, and shrubberies exquisitely laid out. Here resort our merchants, those who can bear the expense of residence beyond the region of smoke. These suburbs of Manchester resemble so many Edens, and you wonder such loveliness can exist so near the brown masses of chimney and streets in the city (geciteerd in Fishman (1987): pp. 75-6).

Ook in de Verenigde Staten krijgt dit ideaal voet aan de grond. In talloze preken loven dominees de rust en voldoening van het gezin als een tegenwicht tegen moreel verval. ${ }^{67}$ Drie stemmen klinken in 
de meeste teksten over het negentiende-eeuwse Amerikaanse suburbia het hardst. De eerste is die van Catherine Beecher, de dochter van een calvinistische predikant. In diverse boeken pleit zij voor de deugden van huiselijkheid. Haar ideaal is een rustig gezinsleven in een landelijke omgeving, het huis is een 'glorious temple' en een 'sanctified home'. Ook Andrew Jackson Downing schrijft aan het ruraal gelegen, vrijstaande huis heilzame krachten toe. Gedreven pleit hij voor ontwerpen die zijn geĭnspireerd door oude Engelse cottages - hun stijl 'strengthens and invigorates our best and holiest affections' (Downing geciteerd in ibid: p. 124). Het leven thuis moet plaatshebben in een omgeving die nog het meest weg heeft van de hof van Eden:

a sunny spot where social sympathies take shelter securely under the shadowy eaves, or glow and entwine trustfully with the tall trees or wreathed vines that cluster around, as if striving to shut out whatever bitterness or strife may be found in the open highways of the world (ibid).

Landschapsarchitect Calvert Vaux, tot slot, treedt in Downings voetsporen. Hij werkt diens visie op het wonen in een natuurlijke omgeving verder uit, niet alleen in publicaties over ontwerpen in het algemeen, maar ook in concrete bouwplannen. Samen met Frederick Law Olmsted realiseert hij bijvoorbeeld New Yorks Central Park. Later geeft hij op basis van dezelfde ontwerpprincipes vorm aan exclusieve buitenwijken.

In de loop van de twintigste eeuw wordt het volmaakte suburbane bestaan in tal van religieuze termen beschreven. Rond de eeuwwisseling, schrijft Gwendolyn Wright bijvoorbeeld in haar geschiedenis van wonen in de Verenigde Staten, is het thema in tijdschriften, gidsen en boeken op het gebied van woningbouw en huishouden 'suburban salvation and security' (Wright (1993): p. 97). ${ }^{68}$ Mary Sies citeert uit het tijdschrift House \& Garden. Daarin wordt in 1904 Lake Forest, een buitenwijk van Chicago, opgevoerd als de toekomst van het Amerikaanse wonen. In mooie huizen met ruime tuinen komt de drukbezette twintigste-eeuwse mens bij van de stress uit zijn werkende bestaan. In de buitenwijk kan hij nieuwe energie opdoen, 'only where it can be truly renewed, in God's own out doors' (Sies (2001): p. 102). 
Typeringen als deze vinden hun weg uiteindelijk ook naar sociaal- en geesteswetenschappelijke studies. Ze worden gebruikt in de omschrijving van zowel idealen als de suburbane werkelijkheid. In het geval van vooroorlogse suburbs vaak om aan te geven dat een droom is verwezenlijkt, in dat van wijken van de laatste vijftig jaar meestal om de keerzijde van het ideaal aan te geven of om de kloof tussen droom en werkelijkheid te benadrukken. Socioloog Harlan Paul Douglass beschouwt de groeiende groep suburbaniserende gezinnen in The Suburban Trend (1925) bijvoorbeeld als 'a chosen people' (Douglass (1970): p. 35). Dorothy Lee is in haar bijdrage aan de bundel Man and the Modern City (1963) minder vleiend. Suburbia stelt teleur, is haar oordeel. In tegenstelling tot de bruisende stad is het leven in de buitenwijk volgens haar vooral een vlak bestaan. 'Is the suburb a "paradise regained"?,' vraagt ze zich af. Enkel als we het paradijs opvatten als

the paradise of harp players agreeably getting along with one another; a paradise of lights without shadows, of virtue rather than of vibrant good; a paradise where people do the right, the acceptable, perhaps even what they ought to do. But it is not a paradise which is the 'blooming, buzzing confusion' of the senses (Lee(1963): p.122).

In Lee's artikel is het beeld van het suburbane Eden niet de gebruikelijke uitdrukking van bewondering, maar fungeert het als contrapunt, als uiting van het hooggestemde ideaal dat in de loop van de jaren vijftig dreigt te mislukken. In haar opvatting staat het suburbane paradijs voor een gebrek aan creatieve spanning, voor een leven dat met de dalen de pieken is kwijtgeraakt. ${ }^{69}$

Vaker echter functioneert de paradijselijke tuin - evenals een daaraan verwante notie als Arcadië (dat een onveranderlijk, onschuldig, vreedzaam en landelijk leven verbeeldt $)^{70}$ - eenvoudig als synoniem voor de buitenwijk. De term is in het suburbiadiscours min of meer gaan gelden als een conventie, een begrip waarover niet meer hoeft te worden uitgeweid. Fishman hanteert 'Eden' als een min of meer neutrale, beschrijvende term. Hij wisselt deze af met typeringen als een 'proper' en 'serious-minded paradise' (Fish$\operatorname{man}(1987)$ : pp. 51, 53). Stern voert de buitenwijk op als een bewoonbaar Arcadiě waarin hij de vrijstaande woning aanduidt als niets 
minder dan een 'house-temple'(Stern (1986): p. 125). Jackson spreekt van een 'Edenic retreat' (Jackson (1987): p. 59), Rowe van een 'sunny Eden'(Rowe(1991): p. 55), Baldassare doopt zijn boek Trouble in Paradise en Joel Garreau duidt zijn edge cities aan als misschien wel de meest doelmatige poging om een nieuw Eden te creëren sinds de tijd van de Amerikaanse Founding Fathers (zie Garreau (1991): p. 14) $)^{71}$

Het paradijs heeft zijn sporen verdiend in het denken over suburbia. Nog steeds is het een verleidelijk beeld, concludeert Stilgoe. Tot op de dag van vandaag, betoogt hij, fungeert het als 'a sort of attic in the national superstructure, a place of calm, a place of older things, a height to visit when downstairs all is commotion, all noisy busyness' (Stilgoe (1988): p. 308). Overdrachtelijk opgevat, heeft het zich vastgezet in onze bovenkamer. In de verbeelde geografie van de buitenwijk staat het paradijs voor een fraaie, groene omgeving waarin alles op zijn plaats is. Maar dat niet alleen. De harmonieuze orde in ruimtelijke zin is er tevens een in temporeel opzicht. Er heerst rust, in de zin dat wat nu het geval is altijd het geval zal zijn. Een volmakkte toestand is bereikt - het gezin geniet bescherming, kinderen bewaren hun onschuld. Behoud daarvan is het enige streven. Dit brengt wel verantwoordelijkheden met zich mee. Orde vereist zelfbeheersing en actieve bijdragen aan het in stand houden van de balans. Verlokkingen dienen het hoofd te worden geboden en bedreigingen van al wat is bereikt, moeten worden afgewend.

\subsection{De pastorale}

De pastorale is net als het paradijs een vast onderdeel van de verbeelding van suburbia. Als literair genre heeft ze haar wortels in de Griekse en Romeinse oudheid. Later is ze een terugkerend thema in genres als de folkloristische en de streekroman, de idylle en de familieroman. Centraal staat een plaats en een tijd waarin het leven nog eenvoudig en eerlijk is. Die plaats is het platteland, de tijd het verleden. Een geïdealiseerd, onbereikbaar, maar in de buitenwijk hopelijk te benaderen landelijk oord maakt een puur, onbedorven bestaan mogelijk. Het sociale leven is er nog niet gefragmenteerd en menselijke activiteiten worden gestuurd door de opeenvolging van seizoenen en de afwisseling van dag en nacht. 
In veel romans en verhalen waarin suburbia de plaats van handeling is, wordt nog steeds nadrukkelijk een pastorale, soms paradijselijke omgeving geschetst. Dat geldt bijvoorbeeld voor Bullet Park in John Cheevers gelijknamige roman (1967). Het wordt niet alleen letterlijk een paradijs genoemd, met zijn bloementuinen en bomen en met plaatsen als Greenacres en Clear Haven in de buurt doet het die naam eer aan. In Yates' Revolutionary Road (1961) zijn het de 'cute little winding roads and cute little houses painted white and pink and baby blue'(Yates (2001): p. 65) die voor de sfeer zorgen. Revolutionary Hill Estates 'was invincibly cheerful, a toyland of white and pastel houses whose bright, uncurtained windows winked blandly through a dappling of green and yellow leaves' (ibid: p. 323). Voortuinen worden er mooi uitgelicht, net als de 'ice-cream colored automobiles' op aangrenzende inritten. Hetzelfde geldt voor recentere romans. In Jeffrey Eugenides' The Virgin Suicides(1993) staan gazonnetjes, bomen en een prachtig meer in een rustige, groene suburb symbool voor de staat van onschuld uit de jeugd van de verteller. In Rick Moody's The Ice Storm (1994) belichaamt het ordelijke, comfortabele, aangename en goed onderhouden New Canaan in Fairfield County New Englands 'pristine quiet'. In Dave Eggers' A Heartbreaking Work of Staggering Genius (2000), om een laatste voorbeeld te noemen, beschrijft de verteller het Lake Forest uit zijn jeugd eveneens als 'pristine' en 'comfortable'. Het is een 'lush and green' oord met mooie parken, een beekje en perfecte voortuintjes. ${ }^{72}$

Hoewel het paradijs strikt genomen stilstand inhoudt en de pastorale eerder staat voor een natuurlijke cyclus, worden beide vaak in één adem genoemd. In geschiedenissen van suburbia geldt met het paradijs de pastorale als het ideaal van de Engelse bourgeois. Zowel het weidse platteland als het preinndustriële, ambachtelijke dorp fungeert als uitgangspunt voor de inrichting van het gebied buiten de stad. Meestal illustreert het naturalistische landschapsontwerp en de traditionele bouwstijl in de vroegnegentiende-eeuwse Londense suburb Park Village de beoogde sfeer: die van een overzichtelijk bestaan, waarin de natuur het tempo bepaalt en waarin veranderingen zich geleidelijk voltrekken en bovendien voorspelbaar zijn.

In de loop van de negentiende eeuw inspireert de pastorale ook de Verenigde Staten. In The Machine in the Garden (1964) onderscheidt cultuurhistoricus Leo Marx twee varianten. De eerste stemt min of 
meer overeen met het genoemde Engelse ideaal. Het geluk op het platteland staat er recht tegenover de hectische, zondige stad. Deze variant is de meest populaire, stelt Marx. Hij noemt haar sentimenteel. De tweede is complexer. Ze komt volgens Marx bijvoorbeeld tot uitdrukking in het New England in Nathaniel Hawthorne's Sleepy Hollow (1844) en in het romantische werk van Emerson en Thoreau. In de schilderkunst is het vooral Thomas Cole die het pastorale landschap gestalte geeft. Zijn doeken bieden een lyrische kijk op een ruraal Amerika gesierd door heuveltoppen met weidse uitzichten, bomen en kronkelende rivieren. Een landelijke omgeving, zeker, maar wel een in ontwikkeling. In Making a Middle Landscape betoogt Rowe dat stilstand er niet eenvoudig tegenover een veranderende samenleving komt te staan. Stilstand onderhoudt daarmee een ingewikkelder relatie. Rowe spreekt van een dialectisch verband tussen de eigenschappen van stad en land. De pastorale biedt een middle ground waar voor elementen uit beide bestaanswijzen plaats is. Niet alleen traditionele sociale verbanden en nostalgische symboliek, ook de negentiende-eeuwse realiteit van technologische vooruitgang komt erin tot uitdrukking. Pastorale natuur is volgens Rowe natuur die langzaam maar zeker in cultuur wordt gebrachteen 'Edenic wilderness' die zich ontwikkelt tot 'a pastoral Garden of Eden, a rural paradise that humanized the impact of development'. ${ }^{73}$ In deze volgens Rowe typisch Amerikaanse vorm van de pastorale wordt terugblikken gekoppeld aan optimisme ten aanzien van de toekomst, een opvatting die zowel Stern als Jackson onderschrijft. Ze geeft uiting aan de morele deugden van een ruraal bestaan in combinatie met - dus niet door ontkenning van - een geloof in materiële vooruitgang. Niet de eenvoudige, maar juist deze complexe pastorale is in Amerika gaan gelden als de ideale woonlocatie, betoogt Rowe. Hij spreekt zelfs van een ideologie, die een belangrijk onderdeel is geworden van het suburbane ideaal (zie Rowe(1991): p. 226).

Met name de negentiende- en vroegtwintigste-eeuwse suburbs waarin dat ideaal fysieke vorm krijgt, worden in diverse studies belicht. Ze gelden als zorgvuldig aangelegde parken waarin romantiek moet samengaan met het geloof in technologische innovatie en economische groei, of zoals Stern het verwoordt, met het 'dollarsand-cents realism' dat aan de basis ligt van riant suburbaan wonen. 
De boodschap is dat een pastoraal bestaan slechts mogelijk is als de afstand tussen de groene suburb en de grijze stad niet groot is. De stabiele sociaal-economische status die nodig is om in dat tempo te kunnen leven op een landelijke locatie berust immers op dagelijkse deelname aan grootstedelijke dynamiek.

Deze dynamiek blijkt bij voorkeur niet uit de namen van buitenwijken, betoogt Dobriner in Class in Suburbia. Country Village, Woodbury Knolls, Pinewood, Green Mansion, Victorian Woods - 'the names of suburbia say, "Come Back!",' schrijft Dobriner. 'Come back to the real things - the green mansions, the sylvan hollows, and sun-sprayed meadows, the private small and uncorrupted little green places. Come back to the permanent, immutable, and trusted forms of nature' (Dobriner (1963): p. 73). Ruim twintig jaar later herhaalt Jackson dit kunstje in Crabgrass Frontier: Rolling Meadows, Highland Hills, Sleepy Hollow, River Grove en Lake Villa - de meeste van deze buitenwijken grenzen aan een grote stad, maar hun namen zullen dat niet verraden, is zijn boodschap. ${ }^{74}$

Nog steeds heeft de pastorale haar greep op de verbeelding niet verloren, concludeert Peter Rowe. Hij geeft voorbeelden van recente artistieke uitingen van de pastorale en wijst daarnaast op de populariteit van historiserende bouwstijlen in suburbia. Ze idealiseren het verleden en staan bol van de traditionele symboliek. Dobriner, tot slot, wijst de pastorale aan als een van de belangrijkste verklaringen voor de trek naar de buitenwijk in veel sociologische studies. ${ }^{75}$ In de eenvoudige variant vlucht men voor 'too many buildings, (...) too much city complexity, (...) too much anxiety, (...) too many risks' (Dobriner (1963): p. 69). In de complexe verlangt men niet alleen naar 'social stability, community, and identity,' maar evenzeer naar 'technological progress'(ibid: p. 72). Staat de buitenwijk in de eerste variant voor een rurale woonomgeving waarin een nostalgische levensstijl en een natuurlijk tempo centraal staan, in de tweede kan de suburbanisant dergelijke vruchten slechts plukken als hij zich niet alleen afwendt van, maar ook inzet vóór vooruitgang. Om te kunnen terugblikken, is vooruitkijken noodzakelijk. 


\subsection{Het pittoreske}

Als de fifties-suburb staat voor thuisblijven en vertrekken, wordt gesproken in termen van de complexe pastorale. In andere gevallen levert de cenvoudige variant samen met het paradijs de bouwstenen voor een beeld van de suburb als rustpunt, als basis voor huiselijkheid en tevredenheid. In dat beeld is vaak nadrukkelijk aandacht voor een specifieke ontwerptaal: het pittoreske. Het pittoreske landschap wordt beschouwd als de inspiratiebron voor de vormgeving van de suburbane woonomgeving. Niet de natuur zelf staat model, maar de natuur zoals verbeeld in de zeventiende-eeuwse schilderijen van met name Claude Lorrain. Een klassiek landschap vormt daarin de setting voor bijbelse en mythologische vertellingen of eenvoudiger scènes met herders en vissers. De omstandigheden zijn er ideaal, de omgeving is tijdloos. Het suburbane ontwerp dat hierdoor is geïnspireerd, moet de suggestie wekken van het traditionele goede leven in een vredige, natuurlijke omgeving. Het landschap is onregelmatig, lijkt idealiter een onbedorven natuur. De woningen ogen ouderwets, lijken een overblijfsel uit het verleden. Met zorgvuldig aangebrachte grillige vormen, verweerd uitziende bouwmaterialen en een schijnbaar toevallige ligging wordt doelbewust een sfeer opgeroepen van traditie, stabiliteit, duurzaamheid, tevredenheid en huiselijkheid.

Wederom dient Park Village veelal als vroeg voorbeeld van dit ontwerpideaal. Het landschap is er volmaakt grillig van vorm, de cottageachtige huizen ademen de sfeer van een eenvoudig bestaan uit een geïdealiseerd verleden. Bovendien wordt het opgevoerd als inspiratiebron voor ontwerpers als Downing en Olmsted. Zij promoten het pittoreske vocabulaire in de Verenigde Staten. Daarin dragen verschillende elementen bij aan een suburbane symboliek. Stilgoe geeft daarvan een aantal voorbeelden. Open velden staan voor rurale deugden, bomen en bergachtig land voor privacy en woningen symboliseren de aanwezigheid van gevoelige, geschoolde mensen die wonen in de omgeving van hun eigen keuze (zie Stilgoe (1988): p. 10). Dit laatste is belangrijk. Van het pittoreske landschap wordt steevast het planmatige karakter benadrukt. Centraal staat dat de suburbanisant zijn lot in eigen hand neemt. Hij bepaalt 
zelf hoe hij leeft en zet de omgeving die hij daarvoor kiest zoveel mogelijk naar zijn hand. ${ }^{76}$

Deze pittoreske esthetiek wordt in uiteenlopende studies op zijn minst op twee manieren uitgelegd en gewaardeerd. Ze wordt gevierd als een ontwerptaal die bijdraagt aan een sfeer zoals die in de hechte gemeenschap in het preïndustriële, ambachtelijke dorp moet hebben bestaan. In dit opzicht worden beroemde buitenwijken als Llewellyn Park, Riverside en Forest Hills Gardens geloofd. In de jaren vijftig is het voornamelijk de kleinere suburb waarin stabiliteit en sociale cohesie tot hun recht zouden komen. In de grootschalige tract, daarentegen, zouden nog slechts bochtige wegen door open grasland en nostalgische tierlantijntjes in en om woningen herinneren aan het pittoreske ideaal. In kritieken geldt dat ideaal als een vorm van escapisme. Het pittoreske geeft vorm aan een vlucht uit de werkelijkheid. Omdat de illusie niet mag worden verstoord, worden armoe, vervuiling, lawaai en overbevolking op afstand gehouden en wordt de technologie van pijpleidingen, stroomdraden en zelfs waslijnen aan het gezicht onttrokken -overmatige controle en een al te grote, benauwende homogeniteit, zo luidt de aanklacht. Op een plek bovendien, die niet meer is dan een kunstmatige creatie van een instant plaats en die aan niet meer ruimte biedt dan een simulatie van een oudere vorm van gemeenschap. In dit fictionele landschap, zo luidt het oordeel, is bedrog het dominante thema. ${ }^{77}$

Hoe dan ook, in beide lezingen staat de gedachte centraal dat de omgeving maakbaar is en dat de suburbanisant haar eigenhandig vormgeeft. Grillige vormen zijn planmatig aangebracht, stabiliteit is een zorgvuldig geènsceneerde suggestie van rust.

\subsection{Defrontier}

Aan de voorraad van paradijselijke harmonie en rust, de pastorale balans tussen stabiliteit en vooruitgang en de maakbaarheid van het pittoreske voegt de zogeheten frontier-mythe onafhankelijkheid en initiatief toe. Ze is een vertelling over pioniers die vanuit Europa naar Amerika reizen en vervolgens steeds verder westwaarts trekken om het nieuwe continent te veroveren en in cultuur te brengen. 'We are a nation of pioneers and immigrants,'schrijft Mark Baldas- 
sare bijvoorbeeld, 'footloose and willing most of all to break new ground and follow new trails' (Baldassare (1986): p. 47). Niet alleen speelt deze mythe een vooraanstaande rol in het beeld van Amerika's verleden, ook in de verbeelding van suburbia is ze een terugkerend verhaal. In grove schetsen is het verband tussen de eerste settlers en de trek naar de buitenwijk bijvoorbeeld te vinden in James Howard Kunstlers The Geography of Nowhere (1993). Kunstler stelt dat het verlangen om de stad te verlaten voor een beter leven elders het verlangen is dat de Pilgrims in de zeventiende eeuw naar Plymouth Harbor bracht. Het is een 'reenactment of the same drama,' schrijft hij, 'the flight from human wickedness and rottenness into nature, the realm of God' (Kunstler (1994): p. 39). Kunstler spreekt van een traditie waarin het door de Amerikanen zo geroemde rugged individualism centraal staat. Hoofdrolspeler daarin is de eenling die niet terugschrikt voor een gewaagde onderneming. Op de hem typerende ironische wijze schrijft Kunstler dat zelfs een hedendaagse assistent-manager regionale verkopen zich erin kan herkennen: 'bethinking himself a pioneer out on some woolly frontier'(ibid: p. 101).

Wordt het verband tussen suburbia en de frontier wat genuanceerder uitgewerkt, dan gebeurt dat meestal in de vorm van een analogie. Zoals de eerste koloniale settlers zich vestigen in een nog onbekende Nieuwe Wereld, ontdekken ook suburbanisanten een nieuw gebied. In Bourgeois Utopias, bijvoorbeeld, voert Fishman de middenklasse op als een pionier wiens keuzen de inrichting van suburbia bepalen. De frontier is de nog niet bebouwde rand van de stad, de suburb 'the conquering outer edge of urban expansion' (Fishman (1987): pp. 12, 135). Wordt serieus werk gemaakt van de relatie tussen suburbia en Nieuwe Wereld, dan geldt de trek naar de buitenwijk als een herhaling van die naar het westen op het nog niet geciviliseerde Amerikaanse continent, waarbij beide bewegingen bovendien worden beschouwd als uitingen van hetzelfde, typisch Amerikaanse, verlangen naar een beter bestaan in een nieuwe omgeving. Ik zal twee voorbeelden geven.

In Pride of Place voert Robert Stern Amerika op als een land waarin zowel de toekomst als het verleden nog vorm moet krijgen, niet alleen in de verbeelding, maar evenzeer in de materiêle omgeving. De suburbane eengezinswoning vervult daarbij dezelfde functie als het huis van de koloniale settler. Beide geven uitdrukking aan wat 
Stern twee traditionele Amerikaanse karaktertrekken noemt: het zich toe-eigenen van het verleden, door vorm te geven aan een eigen versie daarvan, en het zichtbaar maken van persoonlijke ambities voor de toekomst. Het huis van de settler belichaamt zowel de herinnering aan het land dat is verlaten als het voornemen een nieuw bestaan vorm te geven. De twintigste-eeuwse suburbane eengezinswoning, op haar beurt, staat bol van de verwijzingen naar een geidealiseerde koloniale periode $\mathrm{f}^{78}$ en geeft uitdrukking aan de moderne aspiraties en dromen van de buitenwijkbewoner. Beide - hoe ver ook van elkaar verwijderd in de tijd - vervullen volgens Stern op deze wijze een fundamenteel Amerikaans verlangen, namelijk uitdrukking geven aan individualiteit door middel van de eigen woning. ${ }^{79}$ Het bouwen van een eigen huis, stelt Stern, is als individu een nieuwe start maken. Dat huis neerzetten in landelijk Amerika, liefst met de voorkant naar het westen, is pionieren, voegt hij daaraan toe. De Amerikaanse huizenbezitter 'embarks on the creation of a testimonial to his or her dreams,' betoogt Stern (Stern (1986): p. 85). 'To embark on' betekent zoveel als 'aan boord gaan', 'zich inschepen'. De suggestie is dat de Amerikaan een uitdaging aangaat en risico's durft te nemen om een stralende toekomst tegemoet te treden. Deze traditie, luidt Sterns conclusie, brengt elke generatie opnieuw in de praktijk. ${ }^{80}$

Een tweede voorbeeld van de voorstelling van suburbanisatie als een herhaling van de trek west is te vinden in Borderland (1988). Stilgoe plaatst zowel settlers, latere avonturiers als suburbanisanten in dezelfde come-outer-traditie. Steeds scheidt zich een kleine groep af, op zoek naar de voordelen van een bestaan elders, "building anew in the American wilderness' (Stilgoe (1988): p. 8). Interessant is Stilgoe's stelling dat het verhaal op twee manieren kan worden verteld. In de klassieke versie wordt bijvoorbeeld de misère uitgelicht die de puriteinen ontvluchten. Veel historici, betoogt Stilgoe, vragen er impliciet begrip voor dat de eerste immigranten de kans grijpen hun levensomstandigheden, en in morele zin ook zichzelf, te verbeteren. In dit verhaal richten zij hun blik op de toekomst, hopen ze op welzijn, vrijheid en geluk. In de bestseller Epic of America (1931) stelt James Truslow Adams bijvoorbeeld dat de eerste immigranten natuurlijk ook economische motieven hebben, maar dat deze worden geflankeerd door 'the hope of a better and freer life, a life in 
which a man might think as he would and develop as he willed' (Adams geciteerd in Stilgoe (1988): p. 7). Niets minder dan 'the American dream was beginning to take form in the hearts of men,' betoogt Adams (ibid: p. 6).

In Adams' verhaal krijgt inderdaad een episch Amerika gestalte. In versies als deze, stelt Stilgoe, wordt op zijn minst één vraag zelden gesteld, namelijk of zij die westwaarts trekken het land dat zij achterlaten niet schaden. Stilgoe maakt aannemelijk dat de zeventiende-eeuwse puriteinen die in New England neerstrijken, zich er terdege van bewust zijn dat ze zich moeten verantwoorden. Ze benadrukken dat ze gehoor geven aan een opdracht van de Heilige Geest. In de heilige Schrift zoeken ze naar precedenten en vinden ze adviezen. Ze stellen hun tocht gelijk aan de vlucht van de joden uit Egypte. Opnieuw klinkt een stem die oproept Babylon te verlaten. Verlaat Babylon, verlaat Engeland, trek westwaarts, schrijft Stilgoe. Latere generaties bekommeren zich steeds minder om de consequenties van hun vertrek voor achterblijvers. De trek westwaarts over het continent is een verhuizing ergens naartoe, veel meer dan ergens vandaan. Er ontstaat een traditie waarin problemen worden opgelost door deze achter te laten. Gedurende vier eeuwen wordt in preken, schoolboeken en tal van andere publicaties vrijheid van beweging tot een vanzelfsprekend recht, waarbij mogelijke plichten in Stilgoe's optiek al te vaak buiten beschouwing blijven. Wordt een verhaal verteld waarin de aandacht primair uitgaat naar die plichten, dan verandert het oordeel over kolonisten, pioniers en suburbanisanten. Niet lof voor moed en deugd, maar beschuldigingen van laffe desertie krijgen uitdrukking. Op zoek gaan naar ruimte en frisse lucht betekent een stad achterlaten waarin het grote, veelal zwakkere groepen aan een dergelijk comfort zal blijven ontbreken. ${ }^{81}$

Twee versies dus van de aloude trek naar buiten. In de eerste staat de bestemming centraal: een nieuw, leeg, nog in te richten land. De emigrant en suburbanisant verschijnt daarin als een ondernemend individu dat zijn lot in eigen hand durft te nemen. ${ }^{82}$ Hij kijkt vooruit in de hoop dat het hem daar en straks beter zal gaan dan in het hier en nu. In John R. McMahons Success in the Suburbs (1917), bijvoorbeeld, staat succes voor onafhankelijkheid en zelfvoorziening. In de landelijke suburb 'you can attain much of the old frontiersman's independence while having comforts and a full- 
ness of life of which he did not dream' (McMahon geciteerd in Donaldson (1968): p. 555). Ondernemende, energieke stedelingen doen er volgens McMahon goed aan te verhuizen, want de 'real upto-date suburbs, of uncrowded and unfettered Nature, have become the promised land for the city man with limited means but a fair endowment of vim and enterprise' (ibid).

De afgelopen vijftig jaar heeft de tweede versie aan populariteit gewonnen. In Burchard en Bush-Browns The Architecture of America houdt de trek naar de buitenwijk geen oplossing in, maar slechts het achterlaten van problemen. De suburbs - 'without roots, without convictions, without permanence' - die overal en nergens als paddestoelen uit de grond schieten, mogen dan tijdelijk worden gevierd als een gelukkig resultaat van bewegingsvrijheid, de werkelijke gevolgen, zo wordt betoogd, komen pas na 1950 aan het licht. Met name verloedering van binnensteden vormt suburbia's 'terrible toll' (Burchard en Bush-Brown (1961): p. 303). In deze versie gaat de aandacht vooral uit naar het lot van de achterblijver. Vooruitblikken staat gelijk aan een weigering nog om te kijken naar minder gefortuneerden in volle, oude stadswijken en het autonome individu is niet meer de gevierde ondernemer, maar een onverantwoordelijke egoìst.

\subsection{Destad}

Met de buitenwijk als paradijselijk, pastoraal en pittoresk woonoord en als eindbestemming van een eeuwenlange trek naar buiten zijn vier belangrijke culturele ideeën uit suburbia's verbeelde geografie uitgewerkt. Een vijfde plaats- en tijdbeeld dat daarin een vooraanstaande contante is, drukt uit wat de buitenwijk niet is. De stad functioneert als contrast, lange tijd vooral als nachtmerrie van hen die van suburbia dromen, later vooral als het ideaal van hen die gruwen van de buitenwijk.

Volgens historisch geografen Richard Harris en Robert Lewis is er in het denken over Amerika's stedelijke omgeving geen invloedrijker dichotomie dan die van stad en buitenwijk. De tegenstelling is die tussen vuil, herrie, onzedelijkheid, wanorde, overbevolking en opstoppingen in de stad en frisse lucht, ruimte en vogelzang in 
de suburb (zie Harris en Lewis (2001): p. 284). In verschillende varianten wordt deze stelling onderschreven. Mary Sies spreekt bijvoorbeeld over suburb en stad als twee onafscheidelijke dominante culturele metaforen waarin niet alleen opvattingen tot uitdrukking komen over de fysieke omgeving, maar evenzeer over morele orièntaties, leefwijzen en levensstandaarden (zie Sies (2001): p. 319). Robert Fishman benoemt de tweedeling als onderdeel van Amerika's nationale onderbewuste (zie Fishman (1987): p. 154).

In teksten waarin de Engelse oorsprong van suburbia wordt uitgewerkt, gelden negentiende-eeuwse industriesteden als Manchester als poel des verderfs. De Verenigde Staten, zo wordt meestal betoogd, kennen al voor de Industrięle Revolutic een sterk antiurbane traditie. ${ }^{83}$ Met de snelle groei en industrialisering van steden wordt de afkeer alleen maar sterker. Rond de eeuwwisseling waarschuwen medici in rapporten voor ziekten en een lagere levensverwachting van stedelingen. Fotoboeken portretteren overvolle achterbuurten. Met name de misstanden in Jacob Riis' How The Other Half Lives (189o) schokken een groot publiek. Tijdschriftartikelen, essays, verhalen en romans vergroten deze misstanden uit, in advertenties voor landelijk en suburbaan wonen wordt de stad neergezet als een gevaarlijk oord dat men zo snel mogelijk dient te verlaten. Dat deze reclameteksten niet altijd even genuanceerd zijn, illustreert een advertentie uit 1905: 'Get your children into the country. The cities murder children. The hot pavements, the dust, the noise, are fatal in many cases, and harmful always' (geciteerd in Jackson (1987): p. 138).

Rond de stad ontwikkelt zich een vocabulaire waarin ziekten en afwijkingen de hoofdrol spelen. De stad is besmet en besmettelijk. Ze wordt geassocieerd met epidemieën en psychische aandoeningen als agorafobie, claustrofobie en nervositeit. Ze komt - volgens velen met name bij de middenklasse - bekend te staan als bedreiging van zowel de lichamelijke, geestelijke als morele gezondheid. Stilgoe illustreert dit met een artikel uit een nummer van Countryside uit 1917. In 'Why is a suburb?' voert een anonieme vrouw de metropool op als bedreiging van fundamentele Amerikaanse waarden. Zij schetst de stad als een systeem dat niet meer valt te beheersen. Het individu gaat erin ten onder en gezinnen uit het borderland vrezen dat de chaos hun levenswijze zal vernietigen. 'We are called 
Suburbanites and Commuters, and people shrug their shoulders when we have to leave the theater or the dance to catch the last train home,' sluit ze af. 'Little do they realize that in the thousands who scatter every night from New York by tube and train and ferry boat, the real traditions of America are still alive'(Stilgoe (1988): p. 281).

Waar de stad geldt als vuil, ongezond en zondig, wordt de suburb geassocieerd met schoon, gezond en deugdelijk. Bovendien staat het oppositiepaar 'buitenwijk - stad' voor 'zuiver - onzuiver'. Met 'puur en onbedorven' wordt de buitenwijk vaak niet alleen als natuurlijk voorgesteld, maar evenzeer als een woonplaats vrij van vreemden die geen benul hebben van theAmerican way. Tot op de dag van vandaag staat de rol van de etnische 'ander' in debatten over suburbanisatie hoog op de agenda. Staat 'zuiverheid' voor de één voor een blanke, protestantse gemeenschap waarin men thuis is tussen gelijkgezinden, voor veel anderen symboliseert het xenofobie, uitsluiting en racisme. Met name de laatste twintig jaar heeft de stad in dit verband een herwaardering ondergaan. Suburbane overzichtelijkheid is in toenemende mate gaan gelden als een gebrek aan sociale en culturele diversiteit, nostalgie als bekrompenheid en de hang naar stabiliteit als angst voor verandering.

Suburbaan streven naar stabiliteit typeren als angst voor verandering of juist als hoop op behoud van het goede houdt een dynamische interpretatie in. De dichotomie 'buitenwijk - stad' plaatst niet alleen twee statische situaties tegenover elkaar-zoals bijvoorbeeld het suburbane paradijs tegenover 'the bourgeois hell' van de grootstedelijke achterbuurt in Bourgeois Utopias -, maar is tevens een tegenstelling tussen twee verwachtingen. Zoals in de frontier-mythe suburbia traditioneel een belofte inhoudt, zo staat de stad voor de vrees dat het bestaan bergafwaarts gaat. Naast 'dark', stelt Jane Jacobs in haar beroemde pleidooi voor stedelijk leven vast, wordt de stad beschouwd als 'foreboding' (Jacobs (1961): p. 443) - ze bezorgt velen een angstig voorgevoel.

In de roman The Virgin Suicides, bijvoorbeeld, is het verschil in perspectief levensgroot. Vanaf het dak van een van de huizen overzien de verteller en zijn vriendjes de geruststellende gazonnetjes in hun buitenwijk. Er wordt gebadmintond en gebarbecued. In de verte zien ze deze wereld abrupt eindigen: 'where the trees ended (...) the city began. The sun was falling in the haze of distant facto- 
ries, and in the adjoining slums the scatter of glass picked up the raw glow of the smoggy sunset'. Ze horen geschreeuw, geblaf en getoeter - 'sounds of the impoverished city (...), carried on a wind from that place. Then: darkness' (Eugenides (2000): pp. 34-5). Waar het groen eindigt, valt de nacht. Naast toenemende milieuvervuiling betekent de stad in Eugenides' roman de neergang van hele industrietakken, stijgende werkloosheid en armoe. In Tom Wolfe's A Man in Full (1998) is het voornamelijk grootstedelijke etnische dynamiek die aartsconservatief Charlie Croker angst inboezemt. In zijn optiek bedreigt zwart Atlanta zowel de tradities die hij in het landelijke Turpmtine in stand tracht te houden als zijn investeringen in het onroerend goed van de edge city. ${ }^{84}$

Borderland wekt aanvankelijk de indruk de tegenstelling tussen de gelukkige suburbane gemeenschap en de verschrikkingen in de stad op te voeren als een statische oppositie. Tegenover 'the good life (...) in a single-family house in an attractive, congenial community' staat de stad 'as chaotic, inimical to childhood joy, unnaturally paced, incredibly polluted, and just too crowded'(Stilgoe (1988): p. 2). Met name in de slothoofdstukken van Stilgoe's geschiedenis krijgen echter dynamischer beelden gestalte. Gevat in termen als 'inferno', 'cataclysm', 'collapse' en 'destruction' komt de stad te staan voor allerlei vormen van aftakeling. Bovenal functioneert ze als een metafoor voor de dreigende ineenstorting van een sociale orde die geldt als het ideaal van de suburbane middenklasse. Als tegenhanger van de borderlands krijgt de metropool een apocalyptisch aanzien, een beeld dat wordt versterkt door de foto's van verbrande en ingestorte steden die de tekst illustreren. Het stedelijk leven verkeert in de greep van een negatieve ontwikkeling. Het is op weg naar de ondergang.

Ook in Rowe's Making a Middle Landscape, tot slot, belichaamt de stad neergang en verval, zowel in materiële als morele zin. Om onze hedendaagse houding ten opzichte van stad en buitenwijk neer te zetten, put Rowe uit vier mythische vertellingen uit de joods-christelijke traditie. ${ }^{85}$ Elk van de vier levert een archetypisch beeld op. In Nieuw Jeruzalem triomfeert het geloof in God. De mens kan er in volmaakte harmonie met Hem samen zijn. Dit beeld, betoogt Rowe, representeert het paradijselijke bestaan in de buitenwijk. Uit de andere drie kiest hij een beeld dat staat voor de stad. Alledrie con- 
trasteren sterk met Nieuw Jeruzalem. Babylon is een verdorven stad waarin zonden en misdaden welig tieren. In Dante's inferno regeren gierigheid en corruptie. In Babel heerst verwarring, lawaai en chaos. Deze laatste stad komt in Rowe's betoog te staan voor de hedendaagse metropool. Daarmee komt niet alleen een wanordelijke situatic tot uiting, maar evenzeer een ontwikkeling van kwaad tot erger. Net als Babylon vertelt Babel een verhaal. In het narratieve kader waaraan ze zijn ontleend, is het zondige Babylon de opmaat voor een oproep om weg te trekken en is Babel gedoemd te ontsporen. Hun enige toekomst is een neerwaartse spiraal. Het enige levensvatbare alternatieve perspectief is de stad te verlaten, in de hoop, in de hedendaagse stedelijke omgeving, in de buitenwijk een betere toekomst tegemoet te gaan.

Rowe tracht met een nieuwe combinatie van begrippen als 'Nieuw Jeruzalem' en 'Babel' de buitenwijk opnieuw te conceptualiseren. Hij streeft naar wat hij een verrijking van de verbeelding noemt. In het licht van dit expliciete voornemen is het interessant te constateren hoezeer Rowe's betoog is georganiseerd rond vier van de vijf traditionele noties die ik hierboven heb uitgewerkt. Zowel het paradijs, de pastorale, het pittoreske als de stad zijn in Making a Middle Landscape centrale begrippen. Dit terwijl toch, als we ons beperken tot de stad, gedurende de laatste vijftig jaar in uiteenlopende disciplines herhaaldelijk is opgeroepen niet meer te denken in termen van een tegenstelling tussen metropool en buitenwijk. ${ }^{86}$ Het blijkt verleidelijk zelfs een tekst die uitdrukkelijk streeft naar vernieuwing van de verbeelding te organiseren rond een beperkt aantal noties die specifieke plaatsen, tijdperspectieven en handelingsoriëntaties in coherente beelden bijeenbrengen. 


\section{4 \\ Conclusie}

Al in de jaren vijftig en zestig betogen sociologen dat de link tussen buitenwijk, middenklasse en Amerika te gemakkelijk wordt gelegd. In Suburbia (1958) geeft Robert Wood aan dat het mode is te veronderstellen dat wie de suburb onder de loep neemt, het karakter, het gedrag en de cultuur van de Amerikaanse middenklasse uitvergroot te zien krijgt. Maar dat niet alleen. Wood wijst op de gedachte dat de suburbane trend 'our contemporary way of life ${ }^{87}$ zou typeren en dat de buitenwijkbewoner 'by statistical definition, the average American' zou zijn en zelfs 'modern man' zou representeren. Intrigerend is deze 'looking-glass interpretation' zeker en misschien kan het middenklassebestaan ermee worden becommentarieerd, schrijft Wood. Als definitie van suburbia voldoet ze in zijn optiek echter niet (zie Wood (1958): pp. 4-11). Ook Dobriner wijst op het gevaar van de verwevenheid van het beeld van suburbia met dat van het karakter van de middenklasse. Niet alleen in commentaren, maar evengoed in sociaal-wetenschappelijke studies is nog maar lastig uit te maken 'what is endemically suburban and what is constitutionally middle class' (Dobriner (1963): p. 48). Veel beweringen over 'suburban man', 'suburban society' of 'suburban culture' betreffen niet zozeer een bepaalde plek, waarschuwt hij, als wel de levensstijl van de middenklasse (zie Dobriner(1958): p. xxi). Berger, tot slot, plaatst de notie van suburbia als Amerika in een traditie van pogingen om de typische, ware of representatieve Amerikaan en diens levensstijl en gemeenschap te verbeelden. Dat levert slechts stereotypen en karikaturen op, oordeelt hij (zie Berger (1971b): pp. 172-3). Berger haalt fel uit, maar als het gaat om bestrijding van dergelijke beelden - in zijn geval nadrukkelijk een strijd tegen de suburbane mythe - toont hij zich bescheiden, betrekkelijk machteloos zelfs. Met empirisch onderzoek, stelt hij, krijgen we een mythe zelden aan het wankelen (zie Berger (1968): p. xvi). 
In dit hoofdstuk is de continuïteit in de verbeelding van de buitenwijk niet beschouwd in termen van de mythe, maar van een complex stelsel dat vanuit verschillende tradities wordt gevoed en waarvan verschillende onderdelen kunnen worden gekritiseerd zonder dat de formule als geheel bezwijkt. De jaren vijftig spelen daarin een hoofdrol. In het beeld van dat decennium raken suburbia, middenklasse en een ideaal Amerika met elkaar verstrengeld. Literatuurwetenschapper Raymond Federman omschrijft de jaren vijftig bijvoorbeeld als 'a period of valorization and symbolization of the American way of life and the American reality' (Federman (1988): p. 1147). In een essay over fotografie in New Left Review spreekt Laura Mulvey van fifties-ness, dat zij begrijpt als een 'collective American fantasy of the fifties as the time of everyone's youth in a white and mainly middle America setting' (Mulvey (1991): p. 141). ${ }^{88}$ Fifties-ness functioneert volgens haar bovendien als 'a particular emblem of American-ness' (ibid: p. 148). In de jaren vijftig, schrijft ze, geldt 'American-ness as an aspiration for the newly suburbanized, white, population'(ibid).

Het beeld van de suburb als de true site of middle America blijkt allerminst eenvoudig. In de gedachte dat de middenklasse in de buitenwijk op haar plaats is en dat van haar kan worden verwacht dat ze er Amerikaanse idealen tot realiteit maakt, raken belangrijke culturele narratieven met elkaar verknoopt. Het beeld van suburbia als de plek waar de middenklasse veiligstelt wat is bereikt en verlangt naar een stap vooruit berust op grote verhalen over zowel stabiliteit in gezin en gemeenschap als sociaal-economisch opwaartse mobiliteit, materiële vooruitgang en de American dream. Bovendien wordt voor de verbeelding van zekerheid $e n$ ambitie, gemeenschap $e n$ individualiteit, harmonie en autonomie geput uit een voorraad plaats- en tijdbeelden met een lange traditie. Deze worden in verschillende combinaties hernomen. Ligt het accent op thuisblijven, dan worden bijvoorbeeld het paradijs en het pittoreske aangesproken. Wordt vertrekken uitgelicht, dan wordt vaak een verhaal verteld in de frontier-traditie. Ligt de nadruk op de combinatie van beide, dan biedt de Amerikaanse versie van de pastorale uitkomst of kunnen verschillende beelden aaneen worden gesmeed.

De constanten die in dit hoofdstuk in de verbeelding van de buitenwijk zijn aangewezen, mobiliseren een gelaagd geheel van ver- 
gelijkingen, gelijk- en tegenstellingen en connotaties waarin suburbia naast een plaats bovenal een levensstijl en temporele oriëntatie inhoudt. Aan de robuustheid daarvan dragen naast feiten waardeoordelen en emoties bij. De buitenwijk zou de realisatic zijn van hooggestemde idealen, maar evenzeer de jammerlijke mislukking daarvan - ze komt niet alleen symbool te staan voor alles wat mis is met het leven rond de grote stad, maar evengoed voor problemen in samenleving en cultuur in het algemeen. Zelfs als we dominante beelden in deze polemiek niet als mythe, maar als een complex stelsel opvatten, moeten we ervoor waken ons daarop blind te staren. Doordat de buitenwijk fungeert als een arena in debatten tussen uiteenlopende commentatoren, vallen gevarieerde, zelfs onderling strijdige gedaanten aan te treffen. Verbeelding van de gedachte dat dromen worden verwezenlijkt, levert een heel andere versie van suburbia op dan beelden waarin idealen worden verkwanseld. En waar de middenklasse in de ene versie bijvoorbeeld de hoofdrol speelt, is voor haar in een andere slechts een bijrol weggelegd. In hoofdstuk 3 staat het middenklassesuburbia in dergelijke concurrerende gestalten centraal. 

3

In een warm bad kopje onder

De buitenwijk als strijdtoneel 



\section{Inleiding}

Van de middenklasse is altijd veel verwacht. Ze dient, zeker in de jaren vijftig waarin ze het tij mee heeft, een cultureel ideaal te verwezenlijken, zo is in hoofdstuk 2 uiteengezet. In de buitenwijk moet het gebeuren: daar kan een hecht gezinsleven worden gesticht, een kleine gemeenschap gestalte krijgen en bovendien sociaal-economische en materiële vooruitgang worden geboekt. De suburbane middenklasse zou tevreden terugblikken, maar tegelijkertijd verlangend vooruitkijken, naarstig strevend naar verbetering van de eigen positie in de toekomst. Deze temporele orie̋ntatie bleek bovendien nauw gekoppeld aan verwachtingen ten aanzien van karakter en gedrag. Juist door deel uit te maken van een gemeenschap zou individuele autonomie, initiatief en prestatiedrang worden gestimuleerd.

Wat kwam hiervan terecht? Werd er vooruitgang geboekt of bleef aansprekend resultaat juist uit? Terwijl de aard van de verwachtingen altijd veel overkomsten heeft vertoond, lopen de oordelen over wat de middenklasse daadwerkelijk klaarspeelt nogal uiteen. De buitenwijk is een - imaginair - strijdtoneel voor intellectuelen, die strijden om drie verschillende, maar verwante issues. Daarbij gaat het niet alleen om wat er al dan niet tot stand wordt gebracht, ook worden de handelwijzen en handelingsbekwaamheid van de middenklasse verschillend ingeschat, wat in uiteenlopende teksten concurrerende beelden oplevert. Allereerst staat individualiteit op het spel. Belangrijke suburbiakritieken uit de afgelopen vijftig jaar vertonen kenmerken van een dystopisch discours waarin de buitenwijkbewoner geen individu is, maar een type. Deze voorstelling berust bovendien op een uitgesproken negatieve visie op consumeren, traditioneel beschouwd als een van de belangrijkste tijdsbestedingen in de buitenwijk. Wordt anders gedacht over consumptie, dan verandert ook de kijk op suburbia. Tot slot verschillen antwoorden op 
de vraag of de suburbane middenklasse wel handelingsbekwaam is. In verschillende versies van de geschiedenis blijken voor haar heel andere rollen weggelegd. In sommige realiseert ze op eigen houtje een ideaal, in andere is ze daarvoor afhankelijk van allerlei omstandigheden en in weer andere verdwijnt ze zelfs helemaal van het toneel. 


\section{Individu versus kuddedier}

Juist in de periode waarin alles meezit, worden idealen verkwanseld. Met name vanaf de jaren vijftig schetst de suburbiakritiek een zwarte versie van de buitenwijk en haar middenklasse. Gelijkenissen te over tussen de teksten waarin deze gestalte krijgt. Dezelfde thema's, dezelfde zondebokken, steeds leesbare lectuur met prachtige oneliners. Of we, zoals wel wordt gesuggereerd, kunnen spreken van een genre op zich - dat van suburb bashing waarin de suburbane mythe uitdrukking zou krijgen - valt echter te betwijfelen. Daarvoor zijn de onderlinge verschillen te groot. Eerst zal ik aandacht besteden aan een vorm van kritiek die primair is gericht tegen de buitenwijk als gebouwde omgeving, vervolgens aan teksten waarin het karakter van het middenklassebestaan eraan moet geloven. In de eerste heet de buitenwijk een mislukt ontwerp, maar blijven haar bewoners meestal buiten schot. In de tweede staat die mislukking gelijk aan het falen van de middenklasse.

\subsection{Een mislukt ontwerp}

Veel kritiek richt zich tegen de inrichting van de suburbane ruimte en de vormgeving van de woningen daarin. In The Death and Life of Great American Cities (1961) richt Jane Jacobs zich tegen de schade die de vlucht naar de suburb aanricht in de natuurlijke omgeving. Velen verlaten de stad voor de buitenwijk op basis van een sentimentele, niet liefdevolle, maar respectloze opvatting van natuur, betoogt ze. Wat ze aantreffen, of liever, wat ze creëren, is hooguit 'a fictionalized nature' of 'some insipid, standardized, suburbanized shadow of nature'(Jacobs (1961): p. 445). Landbouwgrond en bossen worden meedogenloos opgeofferd aan snelwegen en parkeerplaatsen voor supermarkten, rivieren en lucht raken vervuild. 'And so, each day, 
several thousand more acres of our countryside are eaten by the bulldozers, covered by pavement, dotted with suburbanites who have killed the thing they thought they came to find' (ibid). Wat in suburbia wordt gebouwd, stelt Jacobs bovendien, levert nauwelijks levensvatbare gemeenschappen op. Ze zijn binnen één generatie al niet meer aantrekkelijk. Onder andere vanwege een te lage woondichtheid en een gebrek aan duurzaamheid verwordt 'natuurlijk wonen' binnen een mum van tijd tot een ring van city gray belts.

Uitgebreider is de kritiek van architectuurcritica Ada Louise Huxtable. Ergens moet het bij de grootschalige naoorlogse realisatie van het ideaal zijn misgegaan, schrijft ze in 'An Alternative to "Slurbs"' (1974). Al gauw blijkt ze met 'ergens' 'overal' te bedoelen. Op zowat alle denkbare punten en in elke regio 'the dream of the good life of domestic bliss in a sylvan setting (...) turned into the subdivision nightmare, the dreary look-alike developments, the slums of the future, the "slurbs"' (Huxtable (1974): p. 185). Er is in Huxtable's ogen zoveel mis, dat ze zich bij vlagen verliest in opsommingen van problemen die even onsamenhangend zijn als de buitenwijken waartegen ze ten strijde trekt. Ze toont zich gealarmeerd, teleurgesteld en cynisch en gebruikt de metafoor van een onstuitbaar oprukkend leger om aan te geven hoezeer het Amerikaanse landschap van kust tot kust wordt bedreigd. 'Long Island fields and farms have been invaded by regimented hordes of splitlevels lined up for miles in close, unlovely rows. Boxes called homes march ruthlessly across the prairies of the Middle West' (ibid: p. 186).

Over de inrichting van de ruimte wordt volgens Huxtable nauwelijks nagedacht: te eenzijdig ruimtegebruik, te veel asfalt en auto's, slecht aangelegde wegen, die ook nog eens in rap tempo verstopt raken, geen oog voor de kwaliteiten van de natuurlijke omgeving, te kleine bouwkavels en te weinig faciliteiten en diensten die noodzakelijk zijn voor een goed functionerende gemeenschap. Met de huizen in die ruimte is het zo mogelijk nog erger gesteld. Gemakzuchtige vormgeving op basis van een handvol standaardontwerpen resulteert in geestdodende monotonie. Er worden inferieure bouwmaterialen gebruikt, waardoor het stucwerk bijvoorbeeld onmiddellijk scheurt. De indeling binnenshuis is vaak slecht doordacht en muren zijn te dun. Het draait slechts om winst voor specu- 
lanten. Huizen zijn niet meer dan handelswaar - van 'architectuur' spreken, zou belachelijk zijn.

\subsection{Een falend karakter}

De schade is volgens Huxtable niet slechts van esthetische aard. Gekoppeld aan haar kritiek op inrichting en vormgeving van de ruimte, stelt ze een diagnose op sociaal, cultureel en emotioneel vlak. 'Suburban life is no voyage of discovery or private exploration of the world's wonders (...), concludeert ze, 'it is cliché conformity as far as the eye can see, with no stimulation of the spirit through quality of environment' (ibid: p. 187). De homogeniteit van de gemeenschap zou even groot zijn als die van de huizen en gezellig samenzijn zou al te vaak omslaan in 'neuroses of developmentinspired ennui' (ibid). Wat in suburbia is gerealiseerd, luidt Huxtable's conclusie, is 'the standardization of America on a surprisingly low level'(ibid: p.188).

Met deze koppeling van kritiek op de gestandaardiseerde suburbane ruimte met die op de homogeniteit van de gemeenschap plaatst Huxtable zich in een traditie van grote namen in de suburbiakritiek. Lewis Mumford klaagt in The City in History (1961) steen en been. Met een breed gebaar haalt hij uit naar zowel de gebouwde omgeving als haar bewoners. Hij spreekt van

a multitude of uniform, unidentifiable houses, lined up inflexibly, at uniform distances, on uniform roads, in a treeless communal waste, inhabited by people of the same class, the same income, the same age group, witnessing the same television performances, eating the same tasteless pre-fabricated foods, from the same freezers, conforming in every inward and outward respect to a common mold (...)(Mumford(1961): p. 486).

'Uniformiteit' en 'conformisme' zijn hier de centrale termen. Beide zijn in de jaren vijftig en de eerste helft van de jaren zestig buzzwords van de eerste orde in zowel populaire media, sociale wetenschappen als literatuur. 'Mass-produced, standardized housing breeds standardized individuals, too - especially among youngsters,' waar- 
schuwt psychologe Sidonie Gruenberg bijvoorbeeld in The New York Times Magazine (Gruenberg (1954): p. 14). In Robert Lindners populaire essaybundel Must You Conform? (1956) wordt de conformistische $\operatorname{man}^{89}$ opgevoerd als een 'mechanized, robotized, caricature of humanity (...), a slave in mind and body (...), a lost creature without seperate identity in the herding collectivity (...) (Lindner (1956): p. 23). En in een nummer van het tijdschrift Look uit 1958 opent George Leonard zijn artikel 'The American Male: Why Is He Afraid to Be Different?' als volgt: 'One dark morning this winter, Gary Gray awakened and realized he had forgotten how to say the word " $\mathrm{I}$ " (...). He had lost his individuality'(Leonard (1958): p. 95).

In de sociale wetenschappen komen de invloedrijkste publicaties van de kritische sociologen $\mathrm{C}$. Wright Mills, William $\mathrm{H}$. Whyte en David Riesman. Hun studies vertonen op het eerste gezicht veel overeenkomsten. Kritiek op de suburb houdt een aanval in op de middenklasse, in het bijzonder op haar grote geneigdheid tot aanpassing. De these luidt dat wie in het naoorlogse democratische en welvarende Amerika een vrije, mondige burger verwacht, bedrogen uitkomt. De drie signaleren een opkomst van een volgzaam in plaats van zelfstandig en onafhankelijk individu. Toch zou het te gemakkelijk zijn om te spreken van een eenduidige suburbia- en middenklassekritiek. Hoewel bij alledrie het verlies van individualiteit en autonomie centraal staat, bestrijkt hun gezamenlijke kritiek een groter gebied. Aan bod komt niet alleen de inrichting van suburbs, maar ook de invloed van massamedia, reclame en experts op het bestaan daarin, alsook het verband tussen vrije tijd en werk van kantoorklerken in grote bureaucratische organisaties, hun relatie met collega's en bazen, hun gebrek aan betrokkenheid met het eindproduct waarvoor zij medeverantwoordelijk zijn, het belang van consumptie ten opzichte van productie en zelfs het kapitalistische systeem en de vrije markt in het algemeen. Bovendien is de middenklasse van Whyte niet die van Mills en Riesman en verschillen de verbanden die worden gelegd tussen die middenklasse en hun suburbs. Ook de toon die de drie aanslaan varieert. Ze zijn geen van allen optimistisch, maar medelijden is iets anders dan walging.

Mills' typering van de nieuwe middenklasse is het minst specifiek. Hij spreekt afwisselend van 'new middle class', 'white collar' en 'salaried employees'. Qua beroep gaat het hem om een groep die bij- 
voorbeeld als kantoorklerk, verkoper en leraar haar brood verdient, qua salaris doeit hij op de middeninkomens. Zijn white-collar people bevinden zich 'somewhere in the middle' (Mills (1977): p. 73). De diagnose in White Collar (1951) betreft primair deze middenklasse, niet zozeer haar woonplaats. Het maakt volgens Mills niet zoveel uit of ze in de betere stadswijk woont of in de suburb. In beide zou sprake zijn van de opkomst van de Little Man. Deze kleine man betekent de ondergang van het onafhankelijke individu. In tegenstelling tot de negentiende-eeuwse, ideale zelfstandige boer en zakenman is de white-collar-werknemer geen 'stalwart - vastberaden individual', niet 'his own man' (ibid: p. xi). Hij is onzichtbaar aan de slag in andermans kantoor, waar hij niet alleen zijn tijd en energie besteedt, maar ook zijn persoonlijkheid inlevert, omdat 'getting along' belangrijker is geworden dan 'getting ahead across an open market' (ibid: p. 263).

In White Collar betreurt Mills de ondergang van eigenschappen als visie, wilskracht, spaarzaamheid en volharding. Witteboordenwerknemers maken vaak een gehaaste indruk, maar hebben geen idee waarnaar ze op weg zijn. Bovendien raken ze verlamd door angst, ook al weten ze niet waarvoor ze precies bang zijn. 'They hesitate, confused and vacillating in their opinions, unfocused and discontinuous in their actions' (ibid: p. 353). Hun enige perspectief is langzaam stijgen op een vaststaande, bureaucratische ladder. Hun grote angst is daarop stil te blijven staan. In afwachting van hun lot-zij hebben hun toekomst niet in eigen hand (zie ibid: p. ix) - nemen ze zelf geen beslissingen. Ze tonen geen eigen wil, nemen geen standpunt in en verheffen hun stem niet. De Little Man 'is pushed by forces beyond his control, pulled into movements he does not understand; he gets into situations in which his is the most helpless position' (ibid: p. xii). Mills zet zijn Little Man neer als een 'small creature who is acted upon but who does not act' (ibid).

In Whyte's werk betekent spreken over de middenklasse spreken over de buitenwijk. Het 'spurious ideal of middle-class adjustment' staat gelijk aan 'the quest for normalcy (...) in suburbia' (Whyte (1963b): p. 366). Waar Mills bovendien eerder een soort medelijden toont dan veroordeelt - zijn white-collar man is vaker 'pitiful than tragic' (Mills (1977): p. xii) -, maakt Whyte van zijn afkeer van de buitenwijk geen geheim. 'For a quick twinge of superiority there is 
nothing quite like driving past one of the new Levittown-like suburbs,' schrijft hij in de inleiding van 'The Transients' (Whyte (1953): p.113). De lezer krijgt een dystopisch suburbia gepresenteerd.

To visitors from older communities, the sight of rank after rank of little boxes stretching off to infinity, one hardly distinguishable from the other, is weird, and if they drive along the streets at dusk, when the little blue lights of the television sets begin to shine out of the picture windows, they can speculate that if they were to blink their eyes in proper rhythm the scene flashing by would freeze into one motionless picture. Appalling! If this is progress, God help us ... 1984. But, onlookers are also likely to conclude, one must be sympathetic too; after all, it is a step up in life for the people who live there, and one should not begrudge them the opiate of $\mathrm{Tv}$; here, obviously, is a group of anonymous beings submerged in a system they do not understand(ibid).

Whyte betreurt de opkomst van wat hij de Organization Man noemt. Het gaat vooral om jonge managers (en hun gezinnen) die hun lot in handen leggen van de organisatie waarvoor zij werken. Zij gaan ervan uit dat niet zozeer zijzelf als wel de organisatie hun pad uitstippelt. Of het nu gaat om te verrichten taken of om verzoeken om (weer eens) te verhuizen, carrière maken is een zaak van bevelen opvolgen en voldoen aan verwachtingen. In tegenstelling tot de rugged individualist en independent entrepreneur zien Organization Men zichzelf als 'objects more acted upon than acting' (Whyte (1963b): pp. $363-4) \cdot 90$

In Whyte's optiek is het gedaan met de welbekende Protestant Ethic, opgevat als de 'pursuit of individual salvation through hard work, thrift and competitive struggle' en bovendien beschouwd als 'the heart of the American achievement' (ibid: p.9). Een nieuw sociaal ethos wordt dominant, één dat groepsdruk op het individu legitimeert. Uitgangspunten zijn dat het individu heftig verlangt deel uit te maken van een groep en dat niet de eenling, maar de groep de bron is van creativiteit. Deze Social Ethic komt volgens Whyte het zichtbaarst tot uitdrukking in het naoorlogse suburbia, de slaapstad van de nieuwe generatie Organization Men. In de suburbs - 'communities made in his image' (ibid: p. 246)-komt de jonge manager 
nog beter tot zijn recht dan in de onderneming waarvoor hij werkt. Zijn levenswijze is in elke buitenwijk dezelfde, betoogt Whyte. Doordat hij vanwege het vele verhuizen nergens wortels heeft, zoekt de transient in elke wijk waarin hij tijdelijk neerstrijkt het gezelschap van mensen als hijzelf. Er is sprake van een sterke gerichtheid op de gemeenschap, stelt Whyte. Alles draait om eenvormigheid en homogeniteit (zie Whyte (1963a): p. 46), acceptatie en consensus (zie Whyte (1963b): pp. 277, 325). De suburb functioneert als een 'web of friendship' (ibid: p. 303), een 'socially cohesive block' (ibid: p. 322) waarin het individu wrijvingsloos opgaat.

De buitenwijk - in The Organization Man gemodelleerd naar Chicago's Park Forest ${ }^{91}$ - is 'a womb with a view' (ibid: p. 259). Om daarin te kunnen worden opgenomen, betaalt de Organization Man volgens Whyte een hoge prijs. Koste wat kost deel willen uitmaken van de groep 'is one of the great breeders of neuroses' (ibid: p. 366). De druk zich te voegen naar het sociaal wenselijke is dermate hoog dat voor bevrediging van individuele verlangens of uitingen van individuele creativiteit en initiatieven geen plaats is. Vanwege de vele sociale activiteiten binnen de eigen kring blijft er bovendien geen plaats over voor activiteiten daarbuiten, noch voor bezigheden binnen het gezin. De buitenwijkbewoner wordt zo een gevangene in eigen buurt. Als individu gaat hij in een warm bad kopje onder.

Hoewel Riesmans toon doorgaans minder fel is dan die van Whyte - hij geeft bijvoorbeeld aan niet te willen afgeven op de middenklasse ${ }^{92}$-, verhult ook hij zijn afkeer van het bestaan in de buitenwijk niet. In 'The Suburban Sadness' (1958) expliciteert hij zijn standpunt. Hij kiest het perspectief 'of one who loves city and country, but not the suburbs; one who feels that the suburban styles of life tend increasingly to become the American styles, with ensuing loss of certain kinds of diversity, complexity, and texture (...)' (Riesman (1958): p. 375). Net als Whyte klaagt Riesman over de likemindedness' die het leven van werknemers van grote organisaties zowel op het werk als thuis in de naoorlogse buitenwijk beheerst. Waar Whyte zijn pijlen echter richt op de upper-middle class - op hun levensstijl van aankomen, (overmatig) samenzijn en weer vertrekken -, gaat Riesmans aandacht vooral uit naar de middle- en lowermiddle class. Niet mobiliteit kenmerkt hun bestaan, maar eerder een verlammende status-quo. 
Riesmans suburbs hebben een ander probleem dan die van Whyte. Niet een Social, maar Domestic Ethic heeft het leven in zijn greep. Gezinnen verliezen zich niet in de vele sociale activiteiten, zoals Whyte suggereert, maar trekken zich juist terug in en rond het eigen huis. Veel minder dan bij Whyte bepaalt carrière de agenda. Het streven is primair 'suburban domesticity and peace' (Riesman (1957): p. 131 en (1958): p. 380). Togetherness betekent niet contacten leggen om hogerop te komen, maar in de eerste plaats het onderhouden van relaties binnen het gezin. Het sociale leven is niet georganiseerd rond de club of het comité, maar rond het televisietoestel en de spelletjes in de zogeheten family room en de barbecue in de eigen achtertuin. Hoewel ook Riesmans buitenwijkbewoner gevangen raakt, is deze een ander soort gevangene. Relaties met nietgezinsleden komen onder druk te staan en activiteiten en gesprekken binnen het gezin krijgen een bedenkelijk peil, omdat iedereen eraan moet kunnen deelnemen. Verschillen tussen volwassene en kind en tussen man en vrouw worden gladgestreken, wat buitenwijkbewoners remt in hun ontwikkeling als individu. ${ }^{93}$

Het centrale probleem van Riesmans middenklasse is dat in haar midden de traditioneel 'inner-directed' Amerikaan een 'other-directed social character' ontwikkelt. Waar de eerste in de loop van zijn leven eigen opvattingen en ambities ontwikkelt, stemt de laatste zijn gevoel en gedrag af op de voorkeuren en verwachtingen van anderen. Hij past zich voortdurend aan. Verloren gaat de individualiteit en vrijheid, het initiatief en ondernemerschap die de oude middenklasse van zelfstandige ondernemers en handelaars kenmerkten. Zij is Riesmans toetssteen. Hij voert haar op als de pioneer die met visie en moed de frontier opzoekt, terwijl hij de nieuwe middenklasse neerzet als een slaafse en angstige massamens. In een ongekend welvarende periode is deze niet in staat ook maar in de buurt te komen van Riesmans ideaal.

Minder dan Whyte beschouwt Riesman de buitenwijk in dit betoog als de oorzaak van de grote neiging tot conformisme. Whyte houdt bijvoorbeeld de pleintjes in Park Forest mede verantwoordelijk voor de zenuwslopende togetherness in de buurt. Riesman ziet de suburb eerder als de plek waar trends die ook elders merkbaar zijn, het best zichtbaar worden. Conformisme is in eerste instantie een middenklasseprobleem, maar komt in suburbia het duidelijkst tot 
uitdrukking. Er heerst doelloosheid, stelt Riesman. De buitenwijkbewoner weet niet wat hij wil. Zelf een plan formuleren en streven naar zelfstandige uitvoering ervan maakt plaats voor manipuleren en gemanipuleerd worden. Niet wat iemand zelf is en doet makt hem succesvol, maar wat anderen van hem denken. Waar Riesmans ideale autonome individu over zichzelf beslist, zich niet laat leiden, leert the other-directed zijn verlangens, behoeften en voorkeuren ontkennen. Aanpassing, concludeert Riesman in The Lonely Crowd (1950), kost hem zijn vrijheid.

\subsection{Van wetenschappelijk betoog naar literair verhaal}

Geestdodende monotonie in een gestandaardiseerde omgeving, aanpassing als sociale norm en een schokkend gebrek aan vrijheid: 'Appalling!' in Whyte's termen. 'If this is progress, God help us ... 1984.' De buitenwijken die in de tweede helft van de twintigste eeuw uit de grond worden gestampt, zijn in deze optiek geen paradijs op aarde, maar een regelrechte dystopie. Op afstand van de stad verrijst een nieuw soort gemeenschap waarin uniformiteit, homogeniteit en conformisme een sociale, culturele en emotionele ramp betekenen.

Drie strategieën helpen deze zwarte versie van suburbia neer te zetten. Allereerst is er de kritische intellectueel die als buitenstaander de buitenwijk op afstand bekijkt, deze bezoekt, of er zelfs voor langere tijd zijn intrek neemt. Belangrijk is dat deze getuige, zelfs als hij in de suburb woont, geen deel uitmaakt van de gemeenschap. Hij voelt zich ongemakkelijk bij de gewoonten in de groep en gruwt van de heersende richtlijnen voor gedrag en denken. Hij onderscheidt zich, staat in zekere zin niet alleen buiten de groep, maar ook erboven - denk aan Whyte's betuttelende 'one should not begrudge them the opiate of ' $v$ '. Als buitenstaander beschikt hij over het overzicht waaraan het in de 'herding collectivity' nu juist ontbreekt. Daarmee hangt het tweede kenmerk van dit dystopische beeld samen. In de groep die wordt beschreven is het individu het belangrijkste slachtoffer. De oude onafhankelijke en ondernemende middenklasse is verworden tot een kudde 'lost creatures','objects more acted upon than acting'. Zelfs als één van hen wordt uitge- 
licht, krijgen we geen individu te zien, maar een typische exponent van de groep, een type. Om ons te overtuigen van de ernst van de zaak, wekt de buitenstaander dit type in zijn verslag tot leven, zodat we niet met een abstractie, maar met een concrete persoon of een gezin te maken lijken te hebben. Ondanks zijn vaak overduidelijke normatieve lading wekt dit portret de indruk een beschrijving te zijn. Het beeld van wat zich in de buitenwijk afspeelt, wekt de suggestie een realistische weergave te zijn. Kijk maar, luidt deze derde strategie, $z 0$ erg is het.

In de suburbiakritiek krijgen deze strategieën op verschillende wijzen invulling. Om scherp te krijgen hoe varianten in elkaar steken, dienen we ze onderling te vergelijken. Daarbij moeten we ons niet laten verleiden tot een tweedeling tussen een sociaal-wetenschappelijke en literaire verbeelding. Hoewel bijvoorbeeld de functie van kritische buitenstaander in deze tradities vaak door andere instanties wordt vervuld - in het wetenschappelijk betoog vaak door de auteur, in een literair verhaal door het hoofdpersonage, vaak gesteund door de verteller-, hebben beelden in beide meer gemeen dan wordt gesuggereerd door het label 'sociaal-wetenschappelijk' dan wel 'literair' dat zij traditioneel krijgen opgeplakt. In sommige sociologische studies worden buitenwijkbewoners bijvoorbeeld nadrukkelijk niet als 'feitelijke inwoners' van suburbia gepresenteerd, maar als ideaaltypen die we in de werkelijkheid niet zullen aantreffen. Dat deze beelden toch een realistische indruk wekken, is vaak te danken aan de literaire technieken waarmee ze worden opgevoerd. In sommige literaire verhalen wordt juist wel gesuggereerd dat suburbs en hun bewoners 'op feiten zijn gebaseerd' of wordt de vertelling ingebed in wetenschappelijke studies of analyses die een wetenschappelijke stijl suggereren. Het onderscheid tussen betoog en verhaal raakt zo vertroebeld en is in sommige gevallen helemaal niet meer te maken. Er is geen sprake van een tweedeling, maar van een continuüm. Door een tocht te maken langs een aantal passages uit teksten op verschillende punten op deze glijdende schaal wordt duidelijk dat betoog-en vertelstrategieën in uiteenlopende vormen van suburbiakritiek gradueel verschillen. Tussen Riesmans The Lonely Crowd en Yates' Revolutionary Road (1961) gaapt geen kloof, maar liggen teksten als Whyte's The Organization Man, Keats' The Crack in the Picture Window (1956) en Karps Leave MeAlone (1957). 
In The Lonely Crowd presenteert Riesman zijn other-directed als een ideaaltype (zie Riesman (1950): p. vi). Dat is niet gebaseerd op uitvoerig empirisch onderzoek, benadrukt hij. Het is juist andersom 'the model put forward here (...) was used and is now being used to orient our speculations, to guide our research, and to pose questions for further investigation' (ibid: p. vii). De karaktertypen die hij voorstelt, zijn sociaal-wetenschappelijke constructies die we niet moeten verwarren met echte mensen, benadrukt Riesman. Deze laatsten passen nooit helemaal in zijn schema (zie ibid: p. 172). In volgende publicaties wil Riesman meer cmpirisch materiaal presenteren, voegt hij nog toe: studies van gemeenschappen, karakterstudies van individuen en interviews met tieners bijvoorbeeld. In Class in Suburbia (1963) maakt Dobriner een vergelijkbare opmerking. Hoewel onmisbaar in zijn onderzoek, stelt hij, zullen we de ideaaltypen die hij schetst - bijvoorbeeld de arbeidersklasse in Levittown - in de werkelijkheid niet aantreffen. ${ }^{94}$ Dobriners presentatie van het modelin dit geval een gezin - wekt echter veel sterker dan die van Riesman de indruk een realistische beschrijving te zijn, een accurate weergave van werkelijke buitenwijkbewoners. Hoewel Dobriner vooraf meedeelt dat het niet bestaat, zelfs niet kan bestaan, suggereert zijn stijl het tegendeel. Het gezin, schrijft hij,

lives in a Cape Cod or '49 ranch' house. A family of five, they came from Brooklyn in the fall of 1953 . They left Brooklyn because their four-room flat was already too crowded and a third baby was on the way. Too, Brooklyn was old and crowded. A veteran who wanted something better could finance a Levitt 'resale' with very little cash down - where else could you get a house 'in the country' with a washing machine and refrigerator 'built in' for \$900o? And there was work for skilled patternmakers in Long Island's aircraft manufacturing plants. So it was goodbye Brooklyn hello Levittown and the adventure of home ownership, grass, and neighbors.

In 1962 Levittown was all that it promised to be in Brooklyn ten years earlier. The neighbors on the block proved to be friendly (...). Car pools take the men to work and the wives help each other out during the day. People get along pretty well - except there's this 'know-it-all across the street. He works in the city - takes the train and is always knocking Levittown and how bad the schools are. (...) 
When I was a kid we had 65 in a class and I still got a good education' (Dobriner(1963): p. 104).

Realisme is in deze passage het effect van een aantal middelen. Waar een ideaaltype statisch is, wordt hier een familiegeschiedenis gesuggereerd. Niet alleen wat wordt verteld, is daarbij van belang, ook hoe het wordt verteld, draagt bij aan de illusie. Afwisseling van tegenwoordige en verleden tijd draagt bij aan een dynamische beweging tussen heden en verleden. Eerst wordt de lezer in de tegenwoordige tijd op de hoogte gebracht van de huidige stand van zaken: het gezin woont in Levittown. De verleden tijd neemt hem vervolgens mee terug in de tijd: ze kwamen hier in 1953 naartoe en ze bleven, onder andere omdat de buren zo aardig bleken. Daarna belanden we in de tegenwoordige tijd opnieuw in het heden: nu, tien jaar later, helpen de vrouwen elkaar en rijden de mannen samen naar het werk - hier dagelijkse praktijk, is de suggestie.

Een tweede middel dat het modelgezin tot leven wekt, is het gebruik van details. Zolang het gezin in een Cape Cod of ranch house woont, hebben we duidelijk te maken met een type - een specifiek gezin woont immers niet in dit of dat soort huis, maar gewoon in één bepaalde woning. Maar zo algemeen blijft het niet. Het gezin is bijvoorbeeld niet in de eerste helft van de jaren vijftig naar Levittown verhuisd, maar in de herfst van 1953. Het komt niet uit een grote stad, of uit New York, maar uit Brooklyn, een specifieke wijk. En de man is niet zomaar een geschoolde arbeider, maar verdient zijn brood als patternmaker. We maken kennis met dit gezin, dat ondanks zijn irritante overbuurman tevreden is in Levittown.

Tot slot krijgt dit gezin een stem. Niet alleen de ikvorm op het eind - 'when I was a kid' - draagt daaraan bij. Al eerder wekt Dobriner op subtiele wijze de indruk dat een individu zijn eigen verhaal heeft verteld. Daarvoor wordt de vrije indirecte rede ingezet, een methode om in een parafrase de eigenheid van oorspronkelijke uitspraken te behouden. Veteranen op zoek naar een betere woning in de buitenwijk zijn er genoeg in de jaren vijftig, maar door de suggestie van spreektaal en specifieke uitdrukkingen - 'where else could you get a house "in the country"', 'so it was goodbye Brooklyn hello Levittown' en 'there's this "know-it-all across the street"' bijvoorbeeld - krijgen we de indruk kennis te maken met één enkel individu. 
Niet wat wordt beschreven, maar de beschrijving zelf staat garant voor het realisme van deze passage. Voor een dergelijk effect worden in suburbiastudies nog andere methoden gebruikt. Zo neemt Dobriner de lezer verderop in Class in Suburbia mee tijdens een wandeling door Levittown. Er wordt geen specifieke plek in de wijk beschreven, maar een hypothetische straat opgevoerd. Er speelt zich van alles af en de lezer wordt gevraagd zich voor te stellen dat hij op een afstandje staat te kijken. 'Walk down a Levittown street on a summer evening' (ibid: p. 125), luidt de uitnodiging. In een auto scheuren tieners voorbij en met een boog komt een bierblikje tegen de stoeprand terecht. Uit een huiskamer schijnt het blauwe licht van een televisietoestel, op een oprit sleutelen twee mannen aan een auto. Met een metalig geluid valt gereedschap op de grond. Eén van de twee vloekt, de ander lacht. Loop door Levittown en dit is wat je te zien (en te horen) krijgt, is de suggestie. Misschien niet precies wat zich hier afspeelt, maar wel iets vergelijkbaars. Levittown barst immers van straten als deze, wordt ons voorgehouden. Wat hier gebeurt - en waarvan we zelf als het ware tot in detail getuige zijn -, is typerend voor de wijk. Dat geldt voor de sleutelende mannen en het geldt zeker voor het gezin dat bezig is te verhuizen. We zien twee echtgenoten spullen in een station wagon proppen en hen vervolgens een laatste maal omkijken naar hun oude huis. De man zegt iets, zijn vrouw begint te huilen.

In de realistische illusie in deze passage speelt de getuige een belangrijke rol. ${ }^{95}$ Zijn aanwezigheid in de straat lijkt zo gewoon dat we niet geneigd zijn erop te reflecteren. Ook wat we te zien krijgen, is zo gewoon dat reflectie, in elk geval bij eerste lezing, niet voor de hand ligt. Dat de status van de getuige een problematische is, blijkt als het gezin de straat is uitgereden. We krijgen dan dingen te zien die we als bezoeker van deze wijk niet kunnen zien. Het gezin rijdt een bocht door - 'as it turns the corner, the woman strains to follow the familiar clutter of rooftops etched against the evening sky. Then they are out of sight. She wipes her eyes and turns to the children'(ibid). Waar we tot nog toe alles zelf konden zien en horen, zit er nu - nu het gezin uit het zicht verdwenen is - niets anders op dan de alwetende verteller op zijn woord te geloven. Hoewel zelfs nu de illusie nauwelijks wordt verbroken, spreekt de wijze waarop een en ander in deze straat wordt verbeeld, niet meer voor zich. De 
lezer wordt zich bewust van de constructie van het beeld. Er mag dan de indruk worden gewekt dat we ons in een specifieke straat bevinden - we zien bijvoorbeeld nog de mannen hun gereedschap opruimen en horen nog een hond blaffen -, bij nader inzien wordt een type straat neergezet. Zoals ook de vrouw die haar tranen droogt, geen specifieke vrouw is, maar een belichaming van een model dat dat typisch suburbane, opwaarts mobiele leven leidt. Aan het eind van deze passage is zij bijvoorbeeld niet op weg naar haar nieuwe woning, maar wordt in algemene termen verteld dat 'the new split-level'(ibid, cursivering DH) niet ver weg is.

In The Organization Man vinden we een andere variant van wat we de 'fictionele sociologische impressie' kunnen noemen. Laten we cens kijken naar een stel dat we Dot en Charlie Adams zullen noemen, stelt Whyte voor. Er volgt een imaginair verslag van de nogal hectische eerste dag van een nieuw paar in Park Forest (zie Whyte (1963b): p. 263). Hoewel duidelijk is dat het gaat om een in Whyte's optiek typische verhuizing naar deze buitenwijk ${ }^{96}$, wordt de indruk gewekt dat we twee concrete individuen op de voet volgen. Stijl volgt functie. Het individu is hier een type, namelijk een exponent van Whyte's suburbane middenklasse en daarmee een van de vele inwisselbare bewoners van de buitenwijk, 'a group of anonymous beings submerged in a system they do not understand'. 97

Het individu als type treffen we ook aan in The Crack in the Picture Window, John Keats' felle aanval op projectontwikkelaars, makelaars en hypotheekverschaffers die het als sluwe, nietsontziende geldwolven hebben gemunt op naĩeve nieuwkomers op de suburbane woningmarkt. Keats' tekst is lastig te kwalificeren. De hoofdvertelling is het relaas van de Drones, een jong stel dat begin jaren vijftig een huis koopt in het nieuwe Rolling Knolls Estates in Fairfax County, Virginia, waar het zich financieel nauwelijks redt en vreselijk ongelukkig wordt. Uiteindelijk verhuizen John, Mary en de kinderen naar Merryland Dell, een nieuwe tract op afstand van Washington. Hun bestaan wordt er niet gelukkiger op, wel veel duurder, waardoor ze nog dieper wegzakken in hun ellende. Een roman wil deze vertelling maar niet worden. Slechts bij vlagen weet de ellende van John en Mary de lezer te overtuigen. We volgen de gebeurtenissen op de voet, maar de verstikkende aanwezigheid van de alwetende verteller - overduidelijk niet meer dan een verleng- 
stuk van Keats - verhindert eenvoudig dat de gedachten en gevoelens van de Drones werkelijk de hunne worden. Bovendien onderbreekt de verteller het verhaal meerdere malen met allerlei statisticken en verwijzingen naar artikelen van psychiaters, sociologen, welzijnswerkers en architecten die worden opgevoerd als gecertificeerde, gerenommeerde, competente observatoren die zaken in het juiste perspectief plaatsen (zie onder meer Keats (1957): pp. 49, 71, $81,147-52)$. Hun observaties en opvattingen maken geen deel uit van de wereld van de Drones. ${ }^{98} \mathrm{Ze}$ betreffen het leven in woningbouwprojecten zoals die van de Drones. Want dat is uiteindelijk John en Mary's functie: ze moeten het buitenwijkbestaan illustreren waartegen The Crack in the Picture Window een aanklacht is.

Het verhaal over hun leven is ingebed in een rechtbankscène. In de inleiding en epiloog houdt de verteller een pleidooi tegen 'identical boxes (...) spreading like gangrene' (ibid: p. xi). ${ }^{99} \mathrm{Als}$ aanklager spreekt hij de lezer aan als lid van de jury. Hij legt haar 'de feiten' voor (zie ibid: pp. xii, 193-4). Hoewel hij toegeeft dat de Drones niet bestaan en Rolling Knolls een fictionele suburb is, zijn beide 'firmly grounded, unfortunately, on the shoals of fact' (ibid: p. 7). 'De feiten tonen aan dat' in de development alles wat mis kan gaan, misgaat, zoals uit het leven van de Drones moet blijken. Hun huis is te klein en slecht gebouwd, publieke voorzieningen ontbreken, de buren irriteren, John ziet zijn gezin nauwelijks, Mary verveelt zich te pletter en samen zijn ze niet in staat te stijgen op de ladder. 'Onward and downward' (ibid: p. 69) leidt hun pad. Het ergst is volgens de verteller dat individualiteit eraan gaat. In lijn met Mills', Whyte's en Riesmans aanklachten is conformisme het centrale probleem. De sociale druk is groot en bovendien maken de uniforme huizen bewoners tot een massamens (zie ibid: p. 61). 'Each identical house, with its identical picture window, with its identical dwarf cedars, the identical gullies in the eroding lawns, always the same, the same, the same, row on row' - waar Mary ook gaat, nergens variatie. ${ }^{100} \mathrm{Dit}$ soort fysieke monotonie, besluit de verteller zijn pleidooi, brengt niets anders voort dan 'swarms of neuter drones. I submit, as proved, that these drones are prey to drift and abyssal boredom, and cannot be said to have lives of their own' (ibid: pp. 193-4).

Keats' buitenwijkbewoners leiden geen eigen leven. Karps roman Leave MeAlone telt welgeteld één individu. Is het in Keats' vertelling 
de verteller die de kneuterige huisjes, gazonnetjes en bewoners te kijk zet, in Karps verhaal neemt hoofdpersonage Arthur Douglas die taak op zich - zoals het de eenling in de dystopische traditie betaamt. Arthur verhuist met zijn gezin van New York City - waar hij als redacteur bij een uitgeverij werkt - naar het suburbane Oakstown, Nassau County, op Long Island. Zijn vrouw en kinderen hebben het er onmiddellijk naar hun zin, Arthur allerminst. Hij is geen sociaal wezen, laat de verteller al vroeg weten. 'He just has a stronger backbone - he wants to do it on his own,'(Karp (1965): p. 29) vertelt zijn schoonmoeder. Uit alles wat Arthur denkt en doet, blijkt dat hij individualiteit hoog in het vaandel heeft staan. Tegen collega's zegt hij precies wat hij denkt, in Oakstown vecht hij voor de komst van een bibliotheek, niet alleen omdat deze een concrete aanvulling zou zijn, maar vooral ook als symbool voor intellectuele vrijheid, als een plaats voor gevestigde opvattingen en afwijkende inzichten. Want daaraan ontbreekt het in de suburb. Iedereen praat elkaar na. Voor wie gebaande paden verlaat, is in de kudde geen plaats. Buitenwijkbewoners gedragen zich volgens Arthur "like cows left out in the fields, up to their udders in dung and perfectly happy' (ibid: p. 213).

Hoewel suburbia het ook in Karps roman moet ontgelden, is een belangrijk verschil met The Crack in the Picture Window de ruimte voor onderscheid. Zo heeft makelaar Barney Steel, die het gezin Douglas aan een woning helpt, weinig gemeen met zijn collega's die Keats' Drones erin luizen. Openhartig licht hij Arthur voor over verschillende soorten buitenwijken. Sommige zijn net concentratiekampen, andere zijn veel aantrekkelijker en bieden huizen in talloze variaties. Arthur adviseert hij een suburb waarin culturele bagage op prijs wordt gesteld en niet middle-middle-class Oakstown. 'People live a little bit in each other's back pockets, if you understand what I mean. You can't afford to get mad too easy, you can't afford to be too choosey, you can't afford to be too independent,' waarschuwt hij (ibid: p. 72). Nadat Arthur toch voor Oakstown heeft gekozen, adviseert Steel hem conflicten met zijn buren niet op de spits te drijven. De meesten hebben geen kwaad in de zin, vertelt hij. Ze zijn er voor hun kinderen en willen vrienden maken, 'they want to improve themselves socially. They want to be big frogs in the little pond. Why compete with them when it doesn't matter to you?' (ibid: p. 270). 
Ook Arthurs karakter, gedachten en gedrag worden veel subtieler uitgewerkt dan die van Keats' Drones. Toch ligt de kritiek op het suburbane middenklassebestaan er ook in Karps roman dik bovenop. Om het verschil tussen stad en buitenwijk uit te drukken, wordt bijvoorbeeld uit het bekende reservoir geput. Het stedelijke appartement aan 52nd Street is klein, muf, donker en slecht onderhouden, terwijl suburbaan Oakstown wordt gekenmerkt door 'the houses with their lawns combed and curried and shaved, their flaming displays of rambling roses, the carefully clipped evergreens, the tidy sense of pride and order pronounced by the curving streets' (ibid: p. 217). Dit ordelijke landschap weerspiegelt het keurslijf waarin het sociale leven is geperst. Dat de druk groot is, blijkt niet alleen uit Arthurs bestaan, maar wordt vaak letterlijk in Mills', Whyte's en Riesmans terminologie uit de doeken gedaan. Zowel 'conformisme', 'anpassing' als 'getting along' passeren de revue en omdat Arthurs vrouw Eleanor en haar moeder al snel opgaan in Oakstowns gemeenschap, 'they lost a little of their identity' (ibid: p. 95). Passages als deze laten weinig aan de verbeelding over. Telling - in termen van Wayne Booths The Rhetoric of Fiction (1961) - verdringt showing naar de achtergrond.

Uiteraard is het verhaal te lezen als een portret van een eenling die vecht voor zijn vrijheid en autonomie. In die lezing is Arthur een buitenwijkbewoner die een eigen standpunt inneemt, dit bevlogen uitdraagt en ernaar leeft. Arthur valt echter evenzeer te interpreteren als een middel dat primair in dienst staat van de verbeelding van zijn tegendeel, de groep buitenwijkbewoners die het in Oakstown naar haar zin heeft. Dat het een groep is, vernemen we net als in The Crack in the Picture Window van een expert: ene professor Miles Minton Cameron. In tegenstelling tot Keats' kenners gaat het hier om een fictionele socioloog wiens tekst deel uitmaakt van de wereld van de personages. ${ }^{101}$ Voor de uitgeverij beoordeelt Arthur Camerons manuscript. Het vat in abstracter termen wat Arthur in Oakstown om zich heen ziet. Cameron introduceert de Indifferent Generation, een generatie twintigers en dertigers die in de jaren vijftig de suburb opzoekt. In een stijl die rechtstreeks afkomstig lijkt uit Mills', Whyte's en Riesmans studies wordt een fictioneel equivalent neergezet van de Little Man, Organization Man en other-directed in één. ${ }^{102}$ Het betreft volgens Cameron een 'small-minded group' die 
in haar 'manicured wilderness' gepreoccupeerd is met 'little sins and little moralities' (ibid: pp. 56, 148). Ze schuwt de controverse, beschouwt de individualist als excentriekeling en streeft bovenal naar zekerheid. Ze mag dan voorzichtig carrière nastreven, een grote vlucht zal deze niet nemen - 'the most desperate race the indifferent generation runs is the race to maintain its status quo' (ibid: pp. 282). Slechts kleine verschillen komen tot uitdrukking. De strijd om status is een gevecht op de vierkante millimeter. De groep levert competitie om het voorzitterschap van clubs en comités. Kortom, concludeert Cameron, "its climbing is confined to rather small hills - "ant hills", as one of my students suggested'(ibid: p. 125).

Tegenover Camerons suburbane mierenhoop - en Keats' zwerm, Arthurs kudde en Steels kikkers ${ }^{103}$ - staat het individu. Ook aan Karps roman ligt deze beproefde antiutopische sjabloon ten grondslag. Doordat we Arthurs belevenissen en gedachten op de voet volgen en we de wereld door zijn ogen zien, worden we verleid ons met hem te identificeren. We steunen hem in zijn strijd tegen aanpassing. Een verraderlijker effect van Karps roman is dat we en passant een afkeer ontwikkelen van de buitenwijk. We krijgen een hekel aan mensen die we nauwelijks leren kennen. Camerons uiteenzetting, die als een rode draad door de vertelling is geweven, dient niet zozeer als een kader waarin we Arthur leren kennen, het is veeleer Arthur die fungeert als afzetpunt in een verhaal dat concrete uitdrukking geeft aan Camerons model - dat van een massa weifelende conformisten. Van de buitenwijkbewoners wordt niemand gedetailleerd uitgewerkt. Hun karakter, als groep, ontlenen ze aan het contrast met Arthur. Hoe meer we ons met hem identificeren, hoe bleker het aanzien van suburbia en hoe tammer zijn bewoners.

Hoe grimmig literaire kritiek op de suburbane middenklasse kan zijn, wordt tot slot duidelijk in Richard Yates' Revolutionary Road. Van een presentatic waarin een sociologisch modelgezin tot leven wordt gewekt, zijn we via de fictionele sociologische impressie van een straat en een verhuizing, het niet-bestaande, maar 'op feiten gebaseerde' Rolling Knolls en het sociologisch aandoende ideaaltype van de fictionele professor Cameron aanbeland bij een realistische roman ${ }^{104}$. Qua thematick wijkt deze niet veel af van de voorgaande vormen van suburbiakritiek. Gebrek aan ruggengraat en de heersende kuddegeest staan centraal. Hoe deze kritiek gestalte 
krijgt, verschilt echter. Waar Arthur Douglas in Leave Me Alone helpt een illustratie van Camerons Indifferent Generation gestalte te geven, maken we in Yates' roman kennis met een complex personage: Frank Wheeler. Frank vertelt graag over zijn kijk op het leven. Aanvankelijk zijn we geneigd hem te geloven, maar in de loop van de vertelling gaan we steeds sterker aan zijn woorden twijfelen. Wat overkomt als zelfkennis blijkt een verfijnde en effectieve vorm van zelfbedrog. De kritische gids die ons dystopisch suburbia laat zien, blijkt niet te vertrouwen.

Frank woont met zijn vrouw April en hun twee kinderen midden jaren vijftig aan de rand van Revolutionary Hill Estates, een suburb in Connecticut. Bij een firma in New York heeft Frank een saaie kantoorfunctie - de saaiste baan die je je maar kunt voorstellen, zegt hij graag. April is huismoeder en wordt met de dag ongelukkiger. Het huwelijk van de Wheelers, zo is van meet af aan duidelijk, staat onder druk en uiteindelijk blijken Frank en April zo te verschillen dat het niet meer te redden valt. Waar Arthur in Leave Me Alone als hoofdpersonage tevens de held is, zijn de rollen in Revolutionary Road anders verdeeld. Frank is het hoofdpersonage - wat hij doet en denkt staat centraal en meestal zien we het suburbane bestaan door zijn ogen ${ }^{105}-$, de held is hij allerminst. Die rol, in deze roman een bijzonder tragische, vervult April. $\mathrm{Zij}$ is de meest analytische van de twee, heeft het meeste lef en toont de meeste daadkracht. Als ze doorkrijgt dat kleine veranderingen niet meer volstaan, probeert ze hun bestaan een nieuwe impuls te geven met het voorstel naar Europa te emigreren. Zij kan daar gaan werken, zodat haar man tijd krijgt te ontdekken wat hij graag doet. Frank, die we intussen hebben leren kennen als een oneerlijke slapjanus met een grote mond, reageert zoals verwacht: hij doet alsof Aprils plan een bevrijding betekent uit de suburbane malaise, maar zorgt er ondertussen voor dat van de uitvoering niets terecht komt, zodat alles bij het oude blijft.

Frank zegt niet wat hij denkt en doet niet wat hij zegt. Wat hij zegt, gaat meestal ten koste van het suburbane middenklassebestaan. Zijn walging kan zich moeiteloos meten met die van Keats' verteller. 'It's all the idiots I ride with on the train every day,' vertelt hij bijvoorbeeld Shep en Milly Campbell, een bevriend stel dat alles beaamt wat hij zegt. ${ }^{106}$ 
It's a disease. Nobody thinks or feels or cares any more; nobody gets excited or believes in anything except their own comfortable little God damn mediocrity. (...) It's as if everybody'd made this tacit agreement to live in a state of total self-deception. The hell with reality! Let's have a whole bunch of cute little winding roads and cute little houses painted white and pink and baby blue; let's all be good consumers and have a lot of Togetherness and bring our children up in a bath of sentimentality - Daddy's a great man because he makes a living, Mummy's a great woman because she's stuck by Daddy all these years - and if old reality ever does pop out and say Boo we'll all get busy and pretend it never happened (Yates (2001): pp. 60, 65-6).

Leef je, tegen wil en dank, toch in een dergelijk milieu, zoals de Wheelers zelf, dan is het belangrijk te onthouden wie je bent en te vechten waar je voor staat, houdt Frank zichzelf voor. Het is de enige manier om in de middelmatige en verstikkende buitenwiik als individu overeind te blijven. Belangrijk is niet besmet te worden door 'these damn little suburban types' (ibid: pp. 20, 24).

Frank ziet zichzelf graag als een 'echte man'. In de trein naar huis tracht hij zich daarvan op bezwerende toon te overtuigen.

Could a man ride home in the rear smoker, primly adjusting his pants at the knees to protect their crease (...)? Could a man sit meekly massaging his headache and allowing himself to be surrounded by the chatter of beaten, amiable husks of men (...)?

Hell, no. The way for a man to ride was erect and out in the open, out in the loud iron passageway where the wind whipped his necktie, standing with his feet set wide apart on the shuddering, clangoring floorplates, taking deep pulls from a pinched cigarette until its burning end was a needle of fire and quivering paper ash and then snapping it straight as a bullet into the roaring speed of the roadbed(...)(ibid: p. 102).

Een grotere kloof tussen gedachten en gedrag is nauwelijks denkbaar. Niet door commentaar te geven, maar door hem de ruimte te bieden een ritje naar de buitenwijk in een innerlijke monoloog aan zichzelf te verkopen als een stoer staaltje van een viriele durfal, 
maakt de verteller Frank ronduit belachelijk. Hij mag zichzelf een cowboy wanen, in werkelijkheid is hij allesbehalve een rugged individualist, niet his own man, om hem eens tegen de bekende maatstaf te houden. Hij acht zich superieur aan zijn medeforenzen, maar reist ondertussen elke ochtend netjes in hun midden naar zijn werk. Wat hij ook denkt of zegt, als het erop aankomt de daad bij het woord te voegen, haakt hij af. In tegenstelling tot April is hij doodsbang voor verandering. Hij houdt zich heimelijk vast aan de mensen die hij zogenaamd veracht, zoals de Campbells, en kan niet zonder de voorspelbaarheid van zijn allersaaiste kantoorbaan. Veelzeggend is dat hij zich met voorraadbeheersing bezighoudt. 'Weten wat je hebt, weten wat je nodig hebt en weten wat je kunt missen', luidt de formule die tevens als metafoor voor Franks levenshouding kan worden beschouwd. Symbolisch is ook de kalender in de keuken. Geillustreerd met scènes uit ruraal New England, toont deze naast de betreffende maand ook de voorgaande en volgende, zodat één blik volstaat om een heel kwartaal te overzien. Frank wenst een overzichtelijk bestaan, een bestaan dat niet verrast - zoals een manager zich een volle agenda wenst, licht de verteller toe, omdat die garandeert dat hem tussen nu en het eind van de maand niets onverwachts kan overkomen: 'Ruin and pestilence have been held at bay, and death itself will have to wait; he is booked solid'(ibid: p. 213).

Zijn heimelijke behoudzucht, huichelachtige gedrag en zelfbedrog makt Frank niet gelukkig. Als dertigjarige is hij een van de jongste forenzen in de trein, maar hij voelt zich een man van middelbare leeftijd. Volgens de verteller heeft hij de blik van iemand die is veroordeeld tot een lange, pijnloze dood (zie ibid: p. 68), een goede typering van de wijze waarop Frank in het leven staat. Hij legt zich neer bij het idee dat het almaar minder wordt, zolang hij het verloop van zijn lijdensweg maar kan voorspellen. Maar zelfs daarin slaagt hij niet. April is haar leven met Frank namelijk meer dan zat. Hun huwelijk, vindt ze, is gebaseerd op verachting, wantrouwen en een ziekelijke afhankelijkheid van elkaars zwakte (zie ibid: pp. 202-3). Nadat confrontatie noch negeren een oplossing is gebleken, besluit ze het kind waarvan ze onverwacht en ongewenst zwanger is, te aborteren. Ze overleeft het niet.

Lange tijd lijkt Frank zoals Arthur Douglas tegenover zijn medebuitenwijkbewoners te staan. Uiteindelijk blijkt hij echter, in 
tegenstelling tot Karps personage, uit hun midden de belichaming van het ergste dat de suburbane middenklasse te bieden heeft. Hoewel ze bij vlagen behoorlijk irriteren, staan in Yates' roman niet de Campbells of de praatzieke Helen Givings en haar apathische man Howard in de beklaagdenbank, maar Frank zelf. De verteller biedt hem alle ruimte zichzelf belachelijk te maken en zet hem daarmee genadeloos neer als iemand die publiekelijk hoog opgeeft van individualiteit, visie en daadkracht, maar zich in zowel gedachten als gedrag laat kennen als een onbetrouwbare, afhankelijke en laffe figuur. 
Passief genot of actief vormgeven?

Destelling dat individualiteit en autonomie in de suburb in de loop van de jaren vijftig en zestig ten onder gaan, wordt weersproken, bijvoorbeeld door socioloog Herbert Gans. In de traditie van Berger ageert deze tegen verscheidene vormen van kritiek op het buitenwijkbestaan. Net als aartsrivaal Keats wil Gans laten zien thoe het werkelijk zit' (zie Gans (1982): p. xviii), alleen levert dat een radicaal andere versie van de buitenwijk op. In zijn beroemde The Levittowners (1967) betoogt Gans bijvoorbeeld dat buitenwijkbewoners niet zomaar klakkeloos meningen van elkaar overnemen om 'erbij te horen', maar dat ze ideeën uitwisselen die in hun dagelijks bestaan nuttig zijn. 'Levittowners have not become (...) mindless conformers,' benadrukt hij, 'they remain individuals, fulfilling the social aspirations with which they came' (ibid: p. 154). Bovendien maken critici volgens Gans de fout dat ze conformisme en onderlinge competitie op een hoop gooien, namelijk als instrumenten in het streven naar status. Zowel conformisme als competitie komen voor, geeft hij toe, maar spelen een andere rol dan commentatoren suggereren. Ze helpen de Levittowners juist om te gaan met heterogeniteit en dragen bij aan een gevoel van individualiteit te midden van gelijkgezinden(zie ibid: p. 174).

Op dit strijd toneel staat naast het verwijt van overmatig conformisme en uit de hand gelopen afhankelijkheid versus het verweer daartegen een tweede controverse centraal, over een vorm van handelen die zowel voor-als tegenstanders beschouwen als een van de belangrijkste tijdsbestedingen in de buitenwijk: consumeren. Consumptie wordt traditioneel nauw in verband gebracht met het leven in suburbia. De buitenwijk wordt voorgesteld als 'the realistic outlet for the American dream' (Baldassare (1986): p. 47), 'a utopia filled with happy and prosperous citizens enjoying one another's companionship through the products they consume' (Nicholson 
(1989): p. 212) en 'one vast supermarket'(Riesman (1958): p. 399). Het suburbane bestaan geldt als 'the gadgeted good life' uit de reclame (Berger (1971): pp. 158-9) en 'the good life that lies at the end of the American rainbow' (Newman (1993): Pp. 149-50). ${ }^{107}$ Zowel het dystopisch discours als veel optimistischer vormen van verbeelding van de buitenwijk veronderstellen een bepaalde visie op consumptie. Met de opvatting over en waardering van consumeren, verandert de opvatting over en waardering van de buitenwijk en haar bewoners. Afhankelijk van hoe wordt aangekeken tegen de aankleding van het huis of de aankoop van weer een nieuwe auto, wordt een kortzichtig hedonistische of juist terug- en vooruitblikkende, en een handelende of juist niet-handelende middenklasse neergezet.

\subsection{Consumptie als passief genot}

Voor zowel Mills, Whyte als Riesman betekent consumeren niet produceren, niet werken, niet presteren. Mills spreekt bijvoorbeeld van de teloorgang van 'the gospel of work' van de oude middenklasse door de opkomst van de 'leisure ethic' van de nieuwe (Mills (1977): p. 236). En volgens Riesman volgt na een tijdperk van productie 'the age of consumption' (Riesman (1950): p. vii), wat de ondergang inhoudt van 'work-mindedness' (Riesman (1958) p. 379). Voor alledrie geldt consumeren als een vorm van kortetermijndenken. In hun strijd om status - in Mills' termen 'the panicky ways of prestige' (Mills (1977): pp. 353-4) - kijkt de suburbane middenklasse wel vooruit, maar ligt haar tijdhorizon niet ver weg. Omdat het buitenwijkbewoners erom gaat in de groep te passen, kijken ze voortdurend nerveus op zich heen, zodat ze wat anderen consumeren zo snel mogelijk zelf kunnen aanschaffen. De mate waarin langetermijnambities kunnen worden uitgedrukt in producten is beperkt. Te opzichtige verschillen met de buren, is de gedachte, gaan immers ten koste van het gemeenschapsgevoel. Een kleine opslag kan zichtbaar worden gemaakt met de aankoop van bepaalde producten, een grote sprong voorwaarts noopt tot verhuizing naar een nieuwe buurt. $^{108}$

In deze opvatting is consumeren een belangrijke vorm van conformeren. Omdat smaak en stijl in een consumptiemaatschappij 
belangrijk zijn, wordt onderlinge afstemming van aankopen een effectieve, want zichtbare, vorm van aanpassing. Zoals producten, verschillen ook persoonlijkheden in suburbia nog maar marginaal, betoogt Riesman. 'The consumer today has most of his potential individuality trained out of him by his membership in the consumers' union' (Riesman (1950): p. 80). ${ }^{109}$ Bovendien is consumptie hooguit een vorm van reageren. Anderen - voornamelijk de eigen per group en populaire figuren uit de massamedia - zijn richtinggevend. Hen volgen, is het devies. De consument, stelt Riesman bijvoorbeeld, "is kept within his consumption limits not by goal-directed but by other-directed guidance, kept from splurging too much by fear of others' envy, and from consuming too little by fear of his own envy of the others' (ibid: p. 8o). Kan reageren nog worden beschouwd als een vorm van handelen, in Riesmans typering van consumptie als een 'craving for satisfactions others seem to have, an objectless craving' (ibid) is consumeren nauwelijks meer dan het bevredigen van verlangens. De consument is iemand die niet veel meer doet dan zich overgeven aan hedonisme. Mills gaat op dit punt het verst. Hij spreekt van 'the absorbing grind of passive enjoyment of glamour and thrills' (Mills(1977): p. 238). Consumptie is slechts passief genot en omdat ze de dominante invulling is van vrije tijd, "leisure is made hollow' (ibid: p. 256). Van een betekenisvolle tijdsbesteding kan geen sprake zijn: 'The amusement of hollow people rests on their own hollowness and does not fill it up' (ibid: p. 238). ${ }^{\text {.10 }}$

\subsection{Consumptie als betekenisvolle activiteit}

Geen zwartgallig portret van de suburb en haar inwoners in Thomas Hine's Populuxe (1986), integendeel. In zijn boek over het design uit de periode 1954-1964 spreekt Hine van een 'golden age' (Hine (1999): p. 3) en een 'candy-covered decade' (ibid: p. 6), een tijd waarin consumptieartikelen een welvaart en gemak symboliseren waarvan een eerdere generatie slechts kon dromen. Consumptieartikelen spelen een belangrijke rol in het leven van de 'solidly middle-class', 'the candidates for suburbia, the cream of the American market' (ibid: p. 16), zoals Hine het formuleert. Die formulering is in Populuxe een belangrijke formule: de middenklasse is de buitenwijkbe- 
woner is de consument. In tegenstelling tot Mills' en Riesmans consument is deze actief en als individu betrokken bij wat hij koopt en gebruikt. Koopt hij in een naoorlogse development een standaardhuis, dan past hij het aan de eigen smaak en behoefte aan, bijvoorbeeld door het te decoreren en uit te breiden. Koopt hij een woning in een van de latere suburbs, dan kiest hij voor een eigen variant op een basismodel door uit het aanbod van vele options en features een specifieke combinatie samen te stellen. Dat is nadrukkelijk ook het geval bij de aanschaf van een nieuwe auto. In het Populuxe-tijdperk, betoogt Hine, is het met de gezinswagen gedaan. Het ideaal wordt een eigen auto voor verschillende bestuurders in het gezin. Styling, kleuren en vele extra's maken deze geschikt als uitdrukking van individuele smaak en levensstijl. ${ }^{\text {II }}$

Consumeren is in Populuxe veel meer dan passief en oppervlakkig genot. Het helpt de buitenwijkbewoner zijn positie op de sociaal-economische ladder publiek te maken en zich te onderscheiden van de buren. Het helpt hem evenzeer in zijn streven deel uit te maken van de groep. ${ }^{112}$ Het tonen van goede smaak, de smaak van de groep, is van groot belang, betoogt Hine. Al te luxe inkopen en al te opzichtig consumeren wordt in de meeste suburbs niet gewaardeerd. ${ }^{113}$ Maar materiële objecten zijn in Populuxe meer dan wapens in de strijd om status. Gras, bijvoorbeeld, speelt bij de aanleg en het onderhoud van voortuintjes een subtiele rol. Het ideaal is een goed onderhouden gazon dat zonder onderbrekingen overloopt in dat van de buren. Als buren samenwerken, kan het gras voor een naadloze overgang zorgen. Trotse huiseigenaren willen echter evenzeer het eigen stukje grond afbakenen, stelt Hine. Daarvoor kunnen ze hekken gebruiken, maar die onderbreken wat Hine de 'pastorale continuîteit' noemt. Zorgen dat het gras net iets groener is dan dat van de buurman, en net iets vrijer van onkruid, biedt een oplossing. ${ }^{1{ }_{4}}$ Het maakt een combinatie mogelijk van samenwerking en competitie. Een tweede voorbeeld is de Tupperware party. Deze houdt volgens Hine meer in dan de verkoop van de beroemde doosjes. Ze maakt het de gastvrouw gemakkelijker vrouwen uit te nodigen die ze niet goed kent en maakt het genodigden gemakkelijker een uitnodiging eventueel af te slaan, omdat ze kunnen zeggen dat ze geen Tupperware nodig hebben. Bovendien kunnen zij bij twijfel gemakkelijker beslissen toch te gaan, omdat meestal niet wordt verlangd 
de gastvrouw terug uit te nodigen. Tupperware medieert zo in sociale interacties, Het maakt 'arm's-length sociability' (ibid: p. 35) mogelijk en helpt vooral nieuwkomers in suburbia om te gaan met de onzekerheid en eenzaamheid die, in Hine's termen, deel uitmaken van hun pioniersleven. ${ }^{115}$

\subsection{De doe-het-zelver als coproducent van suburbia}

De beroemdste pioniers zijn de inwoners van de Levittowns. Zowel in studies die een uniform, monotoon en benauwend suburbia neerzetten als in die waarin gemeenschapsleven en daadkracht hand in hand gaan, zijn de Levittowns exemplarisch. Vaak wordt volstaan met het enkelvoud. Levittown wordt als prototype neergezet, waardoor specifieke verwijzingen naar één van de drie door Levitt and Sons gebouwde suburbs niet nodig zijn. Wordt ingezoomd, dan liggen de Levittowns opeens op Long Island, in Pennsylvania en New Jersey. Bovendien blijken bewoners - zowel middle-als lower-middleclass - onderling te verschillen. In Harold Wattels sociologische studie op Long Island verschillen onder meer kledingstijl, kookgewoonten, hobby's, politieke opvattingen en de keuze van vrienden. Het zichtbaarst komt individualiteit tot uitdrukking in aanpassingen in, aan en rond het huis. Nadat Levitt zijn woningen identiek heeft opgeleverd, slaan eigenaren aan het veranderen. Interieurs worden naar eigen oordeel ingericht. Wattel heeft oog voor kleuren materiaalkeuze, stijlen en objecten. De individuele smaak laat zich misschien sturen door de projectontwikkelaar, binnenhuisarchitecten en massamedia, hij laat zich daardoor niet aan banden leggen. Dat geldt ook voor aanpassingen aan het huis zelf. Het wordt geschilderd, gedecoreerd en uitgebreid. Er worden zolderkamers verbouwd, kelders gegraven en serres, garages, slaap-, eet- en woonkamers toegevoegd. 'The individuality that each family brought to Levittown continues to show through in many ways,' concludeert Wattel - 'within the Levitt framework, a great deal of individual living is taking place'(Wattel (1958): Pp. 297,301).

Vijfendertig jaar later is dat in Expanding the American Dream (1993) van architectuurhistorica Barbara Kelly niet anders. Building and Rebuilding Levittown luidt de ondertitel en in het voorwoord wordt 
duidelijk dat in deze suburb op Long Island 'deliverer-designed housing' geleidelijk verandert in 'owner-redesigned homes'. Kelly geeft aan dat Levittowns huiseigenaren veel onafhankelijker zijn van de projectontwikkelaar dan zij had verwacht. Ze voert hen op als coproducenten van hun buitenwijk. Ze herontwerpen tuinen en interieurs en beschouwen het huis letterlijk als een kader - 'a basic framework' - waarbinnen ze hun dromen kunnen vormgeven. ${ }^{116}$ Voor leden van de arbeidersklasse levert een eigen woning de (lagere) middenklassestatus op, voor witteboordenwerknemers eindigt het opwaartse traject wat hoger. Sommigen beschouwen hun huis in Levittown als een eerste halte op weg naar groter wonen en verlaten de wijk zo snel als mogelijk is. Voor anderen betekent moving up geen vertrek, maar werken aan verbetering in de eigen buurt. Ze beschouwen de eigen woning als een investering waarvan ze de waarde kunnen verhogen door te verbouwen en uit te breiden. Dat levert volgens Kelly niet alleen een gevarieerde woonomgeving op, maar evenzeer een 'concomitant sense of empowerment as these homeowners shaped both their environment and them selves' (Kelly (1993): p.161).

Tegenover het Levittown volgens critici plaatst Kelly dat van bewoners. Niet als een waarheidsgetrouw verhaal tegenover een vertekend beeld, maar als een vorm van folklore die bewoners helpt betekenis te geven aan hun ervaringen in de suburb. Hun 'traditional history' presenteert Kelly uitdrukkelijk als een pioniersgeschiedenis. Het hervertellen van de pioneer saga - tijdens jubileumvieringen, bij diapresentaties, op videobanden, in nieuwsberichten op televisie en in kranten - helpt de Levittowners remodelling en landscaping te beleven als uiting van individualiteit en de samenwerking tussen nieuwkomers als lotsverbondenheid. Diezelfde combinatie komt tot uitdrukking in verhalen die Rosalyn Baxandall en Elizabeth Ewen in Picture Windows (2000) optekenen. Net als Kelly laten zij bewoners zelf aan het woord. Naast het pioniersgevoel 'we were all pioneers' (Baxandall en Ewen (2000): p. 156) - en het belang van individualiteit - 'every house has a signature' (ibid: p. 165) - geven zij uiting aan het gemeenschapsgevoel dat hun bijdrage aan de vormgeving van de wijk oplevert. Levitt bouwde de huizen, de bewoners de gemeenschap, vertelt bewoonster Beth Dalton bijvoorbeeld. ${ }^{117}$ 
Met het gevoel van individualiteit, daadkracht en gemeenschap geven het huis en de dingen erin en eromheen bovendien uitdrukking aan de temporele orièntatie die in hoofdstuk 2 zo'n centrale rol speelde in het aaneensmeden van verschillende noties tot de true site of middle America: de combinatie van terugblikken en vooruitkijken, het belang van thuis zijn en vertrekken. Hine spreekt van een balans tussen 'the look of motion and efficient technology' en 'the look of togetherness, the imagery of early America and a nation that was founded, so one furniture advertisement put it, "by families like yours"' (Hine (1999): p. 8). De Populuxe-periode wordt volgens Hine gekenmerkt door een obsessie met de toekomst en een preoccupatie met het pioniersverleden. Zoals Disneyland de keuze biedt tussen Frontierland en Tomorrowland, zo ook het suburbane huis. Gebruiksvoorwerpen en meubilair roepen in een en dezelfde woning zowel verschillende historische perioden op, als de toekomst. De eetkamer oogt bijvoorbeeld Early American, de keuken futuristisch. Soms worden verleden en toekomst zelfs in een enkel object verenigd - een populair materiaal in die tijd is 'antiek-wit' plastic(zie ibid: pp. 8-14, 53). ${ }^{118}$

Waar Hine zich richt op gebruiksvoorwerpen, gaan Robert Stern en Peter Rowe respectievelijk in Pride of Place (1986) en Making a Middle Landscape (1991) vooral in op het huis. Hun boodschap is dezelfde: de gerichtheid op zowel het verleden als de toekomst wordt zichtbaar in de vormgeving van de suburbane eengezinswoning. Soms komen beide inspiratiebronnen in een enkel huis tot uitdrukking. Stern wijst op de combinatie van allerlei historiserende stijlen als uitdrukking van thema's uit de nationale geschiedenis en bijvoorbeeld zwembaden en sundecks als toonbeeld van ambitie en prestatie. Rowe signaleert een spanning tussen traditionele figuratieve thema's en motieven in ontwerp en decoratie enerzijds en de hightech voorzieningen en uiterst moderne, praktische indeling van de woning anderzijds. Hij spreekt van 'moderniteit vermomd als traditie' en munt zelfs een nieuwe term: 'modern pastoralisme'. Eenduidiger is de symboliek van een aantal klassieke Amerikaanse woningtypen. Huizen in Colonial Revival-stijl, bijvoorbeeld, herinneren aan Amerika's koloniale verleden. Ze zijn met name in trek 
bij de upper-middle class, die er haar gevestigde maatschappelijke positie mee wil uitdrukken. De bouwstijl en bijpassende decoratie verraadt een hang naar stabiliteit en roept associaties op met sociale respectabiliteit, duurzaamheid en traditie. De suggestie van toekomstgerichtheid wordt ontleend aan een ander verleden. De bungalow en de ranch refereren niet aan het gemythologiseerde verleden aan de Amerikaanse oostkust, maar aan de pioniersgeest uit het westen. Beide woningtypen zijn vooral populair in nieuwe developments, bij jonge gezinnen die nog aan het begin van hun carrière staan. Ze ademen een sfeer van avontuur en durf, van optimisme en geloof in vooruitgang in het algemeen en opwaartse mobiliteit in het bijzonder. ${ }^{119}$

Deze versies van suburbia hebben met die van bijvoorbeeld Riesman weinig gemeen. Kritiekloos zijn ze niet - Gans wijst bijvoorbeeld op conflicten in de suburbane gemeenschap, Hine op de eenzaamheid van huisvrouwen en de uitsluiting van zwarten en alleenstaanden. Maar hoewel Gans toegeeft dat de buitenwijk niet de hof van Eden is en Hine stelt dat bewoners drommels goed weten dat ze niet in het paradijs of een pittoresk park wonen, betogen beiden dat verhuizen voor veel suburbanisanten een enorme verbetering betekent (zie Gans (1968): hoofdstuk to en Hine (1999): hoofdstuk 2). Het verschil met de boodschap dat verwachtingen niet zijn ingelost - zowel wat betreft karakter en handelwijze van het individu als sociaal gedrag in de gemeenschap -, is levensgroot. Aloude Amerikaanse idealen vertonen geen tekenen van slijtage, maar worden juist steeds breder gedragen. In Populuxe is de suburb een beloning voor hard werken en de 'fulfillment of the American dream' (ibid: p. 43). In Expanding the American Dream geldt de buitenwijk als een prestatie van formaat. Ze maakt de Amerikaanse droom betaalbaar. De huizen zijn er misschien klein en uniform, schrijft Kelly, voor bewoners 'they were an opportunity to build a better life, a first step on the road to success'(Kelly (1993): p. 147). 
Naast het onderscheid tussen de buitenwijkbewoner als volgzame slapjanus of juist ondernemend individu en tussen zijn consumptiedrift als passief hedonisme of juist actieve levenshouding kenmerkt nog een derde verschil de verbeelding van suburbia. Dit komt het duidelijkst tot uitdrukking in geschiedenissen van de buitenwijk. Geldt de middenklasse in de ene versie als de vormgever van het suburbane ideaal, in tal van andere wordt haar handelingsvrijheid door allerlei omstandigheden aan banden gelegd. Ook een combinatie van beide is mogelijk: in een van de belangrijkste historische bijdragen aan de verbeelding van suburbia legt de middenklasse aanvankelijk iedereen haar wil op, maar geeft ze uiteindelijk haar lot volledig uit handen.

\subsection{De middenklasse als motor van de geschiedenis}

In de eerste helft van Robert Fishmans Bourgeois Utopias (1987) speelt eerst de gegoede burgerij en later een bredere laag van de middenklasse de hoofdrol. Ze formuleert een ideaal, realiseert het en is daarmee verantwoordelijk voor de bloei van de buitenwijk. Suburbia, zo leidt Fishman zijn boek in, is de uitdrukking van het waardestelsel van de middenklasse, van 'a powerful cultural ideal' en 'a compelling vision'(Fishman (1987): p. x). Willen we het ontstaan en de bloei van suburbia begrijpen, dan moeten we het zelfs opvatten als een utopie. De buitenwijk is 'the collective creation of the AngloAmerican middle class: the bourgeois utopia'(ibid).

Suburbia evolueert niet automatisch of onvermijdelijk uit de premoderne stad, betoogt Fishman, en al helemaal niet uit de verachte suburbes die in de achttiende eeuw rond de stad liggen. Integendeel, de opkomst vereist een volledige transformatie van stede- 
lijke waarden: een omkering van de waardering van kern en periferie, een radicale scheiding van wonen en werken en fysieke afstand tussen de klassen. 'Hoe komt dit tot stand?' vraagt Fishman zich af. Zijn antwoord schuilt deels in zijn formulering van de vraag: "Who then invented suburbia and why?' (ibid: p. 8, cursivering DH). Fishman vraagt naar de identiteit van een uitvinder en naar de aard van zijn motieven. Zijn antwoord krijgt de vorm van een geschiedenis waarin de centrale these luidt dat suburbia 'was indeed a cultural creation, a conscious choice based on the economic structure and cultural values of the Anglo-American bourgeoisie' (ibid: pp. 8-9, cursivering $\mathrm{DH}$ ).

Het is zeker niet zo dat de buitenwijk in Fishmans ontstaansgeschiedenis ineens uit het niets haar uiteindelijke vorm krijgt. Er wordt een proces van trial and error geschetst en tal van relevante ontwikkelingen vormen randvoorwaarden voor de opkomst van suburbia. Toch staat steeds opnieuw expliciet de vooraanstaande positie van de middenklasse te midden van die omstandigheden centraal. Suburbia is 'an original creation', stelt Fishman, 'not the automatic fate of the middle class in the 'mature industrial city' or an inevitable response to the Industrial Revolution or the so-called transportation revolution' (ibid: p. 9). ${ }^{120}$ De middenklasse neemt haar lot in eigen handen, is Fishmans boodschap. De geschiedenis van de buitenwijk moet daarom een cultuurgeschiedenis zijn van de Anglo-Amerikaanse burgerij en haar visie. Zij is de pionier 'whose collective style and choices define the nature of suburbia' (ibid: p. 12). Belangrijk is de wijze waarop Fishman de middenklasse in zijn historische verhaal inschrijft. Hij kiest er niet voor, zoals in veel suburbiaonderzoek gebruikelijk is, de reeds gebouwde omgeving te lezen, maar laat zien hoe deze gaandeweg gestalte krijgt. Hij volgt op de voet hoe aanvankelijk abstracte ideeěn materieel vorm krijgen en kiest daarbij als belangrijkste perspectief dat van de burgerij. Wat houdt haar bezig? Waaraan hecht zij waarde? Wat zijn haar overwegingen en, belangrijker nog, welke beslissingen neemt zij op basis daarvan? Het effect is dat de middenklasse als handelend subject de motor wordt van de geschiedenis, en bijvoorbeeld niet de landadel of de groeiende arbeidersklasse in de industriezones. Het is de burgerij die doelen formuleert en deze vervolgens naar eigen inzicht verwezenlijkt. In Fishmans geschiedenis beschikt 
zij over 'the resources and the self-confidence to reorder the material world to suit its needs', 'to remake the world to suit its values' (ibid:pp.9, 26).

Mary Sies' portret van de suburbane middenklasse vertoont met dat van Fishman grote overeenkomsten, vooral wat betreft terminologie. In 'The City Transformed' (1987) en 'North American Suburbs, 1880-1950' (2001) concentreert Sies zich op de wijzen waarop de zogeheten new professional-managerial class het suburbane ideaal tot uitdrukking brengt. Naast aandacht voor idealen als 'self-reliance, aggressive mental initiative, and force of personality' (Sies (1987): p. 86) ligt de nadruk op visie en daadkracht. Sies spreekt van het uitdragen van opvattingen en ambities, de formulering van een ontwerpprogramma en van de gebouwde omgeving, ideeěn en levenswijze als belichaming van een ideologie (zie ibid: p. 83 en Sies (2001): pp. 328-9). Een ideologie die bovendien uiterst effectief aan de man wordt gebracht, 'through a decades-long campaign, (...) codified, packaged and sold to a broad North American public' (ibid: p. 329). Sies' middenklasse hanteert diverse strategieën. De eigen planned suburbs functioneren als modelgemeenschappen ${ }^{121}$, er worden buitenwijken voor de arbeidersklasse gerealiseerd en het suburbane ideaal wordt gepromoot in wetenschappelijke en populaire tijdschriften, in cursussen en winkels, 'aggressively advertised as the goal toward which all American families should strive' (Sies (1987): pp.105-6).

Deze laatste strategie is het grootste succes. Hoewel het volgens Sies door massaproductie al na de Eerste Wereldoorlog veel van zijn glans verliest, wordt het suburbane ideaal de standaard voor twintigste-eeuws wonen in de Verenigde Staten. In Fishmans geschiedenis krijgt de buitenwijk haar klassieke vorm in de eindnegentiendeeeuwse railroad suburb, 'the bourgeois monument' (Fishman (1987): p. 134). Toch ligt de climax in Bourgeois Utopias later. Exemplarisch is Los Angeles, dat zich in de eerste helft van de twintigste eeuw ontwikkelt tot een suburbane metropool. Als nooit tevoren komt het ideaal er tot bloei. ${ }^{122}$ De vrijstaande eengezinswoning komt voor een brede middenlaag binnen handbereik en wordt het centrale element in een hele stad, in plaats van slechts in de periferie. Tot in de jaren vijftig heerst in Los Angeles de ideale balans tussen het urbane en rurale. De middenklasse ziet haar ideeẽn en inspanningen be- 
kroond met een huwelijk tussen stad en platteland, volgens Fishman het teken van de ware buitenwijk.

\subsection{Geschiedenissen vol multiplex, bouwgiganten en subsidies}

Tegenover de middenklasse die middels een wilsbesluit en doelgericht handelen een droom werkelijkheid maakt, staan geschiedenissen waarin zij slechts een van de vele factoren is die bijdragen aan de bloei van suburbia. Naast een bepaald waardepatroon, zo leidt Kenneth Jackson Crabgrass Frontier (1985) in, zijn onder meer de stand van de technologie, de samenstelling van de bevolking, grondprijzen en sociale relaties van groot belang voor hoe er in een bepaald land in een bepaalde periode wordt gewoond. Wie in een geschiedenis de nadruk legt op het één, lijkt hij te impliceren, houdt minder ruimte over voor het ander. Van de vele verschillende accenten die in uiteenlopende studies worden gelegd, zal ik er hier slechts een beperkt aantal aan de orde stellen. Het gaat me er niet om alle mogelijke verklaringen van het succes van de suburb uit te werken, maar om aan te geven dat voor Fishmans en Sies' versies van de geschiedenis alternatieven bestaan.

In sommige teksten wordt expliciet de doelgerichtheid en onafhankelijkheid van de suburbane middenklasse in twijfel getrokken. Historicus Henry Binford zoekt voor zijn verklaring van de ontwikkeling van negentiende-eeuws suburbia aansluiting bij Sam Bass Warners klassieke Streetcar Suburbs (1962). Van duidelijk geformuleerde doelstellingen is vaak geen sprake, betoogt hij. De ligging van trolleylijnen en de waarde van de grond zijn veel bepalender. Van planning en doelbewust ontwerpen door experts kan vaak nauwelijks worden gesproken en gedeelde waarden krijgen slechts vaag uitdrukking (zie Binford (1988): pp. 41, 42, 53). Stephanie Coontz ondermijnt in The Way We Never Were (1992) het wijdverbreide idee van het zelfstandige Amerikaanse gezin. Zoals de archetypische 'self-reliant pioneer family' afhankelijk was van talloze vergunningen en overheidsinvesteringen, zo kan ook het suburbane gezin in de jaren vijftig niet zonder subsidies en leningen, hoezeer Amerikanen ook in het tegendeel geloven. Bovendien betekent zelfredzaam- 
heid van het gezin in die jaren volgens Coontz primair onafhankelijkheid van de man. Van de vrouw wordt als zorgende huismoeder een ondersteunende rol verwacht. 'American individualism', stelt Coontz, leunt zwaar op de onderdrukking van 'women's individuality' (Coontz (1992): p. 41). ${ }^{123}$ Antropologe Katherine Newman, tot slot, benadrukt in Declining Fortunes (1993) dat de suburbaniserende middenklasse in de jaren vijftig gewoon geluk heeft gehad. Ze is op het juiste moment geboren. Newman ontkent niet dat gezinnen hard hebben geknokt voor hun huis in de buitenwijk, maar wijst erop dat Amerikanen de invloed van de ongeèvenaarde economische hoogconjunctuur en de enorme overheidsbestedingen al te gemakkelijk uit hun verhalen weglaten. Amerika mag dan geloven dat visie, inzet en competitie bepalend zijn, de rol van 'sheer good fortune' (Newman(1993): p. 89) mag niet worden uitgevlakt. ${ }^{124}$

Andere versies van de geschiedenis plaatsen bij de visie en autonomie van de middenklasse niet zozeer kanttekeningen, maar voorzien deze van een bredere context. In sommige gaat de aandacht uit naar de stand van de technologie en de beschikbaarheid van bouwmaterialen en productiemethoden. Architectuurhistorica Gwendolyn Wright wijst bijvoorbeeld op de standaardisering en mechanisering van de industriële productie die nodig is voor het naturalistische effect en de individuele expressie van woningen in de eindnegentiende-eeuwse suburb. Panelen en stenen kunnen met behulp van sjablonen fabrieksmatig worden geproduceerd en 'ambachtelijke' ornamenten rollen per strekkende meter van de band. Ze worden per trein getransporteerd en ter plaatse 'vastgetackt' of -gelijmd. Op transportgebied noemt Wright naast de introductie van de trolley de aanleg van snelwegen, bruggen, tunnels, rotonden en geschakelde verkeerslichten als voorwaarden voor suburbanisatie (zie Wright (1993): hoofdstukken 6 en 11). Ann Durkin Keating (1989) benadrukt het belang van rioolsystemen en de aanleg van gas- en waterleidingen en Stephanie Coontz het door de overheid gefinancierde onderzoek naar materialen als aluminium en multiplex - alle onmisbaar voor de explosieve naoorlogse huizenbouw.

Een andere context komt tot stand als actoren op het historische toneel worden beschouwd als leden van uiteenlopende belangenen beroepsgroepen. In de eerste helft van de twintigste eeuw wor- 
den in Wrights bouwgeschiedenis verschillende coalities gesmeed: tussen projectontwikkelaars en makelaars, architecten en bouwondernemingen, overheidsambtenaren en sociologen, interieurontwerpers en huisvrouwen, vakbonden en hervormingsgezinde intellectuelen, zoning boards en verenigingen van huiseigenaren (zie Wright (1993): hoofdstukken 11 en 13). Hoewel nauw betrokken bij de inrichting van de buitenwijk, wonen velen in de stad. En hoewel velen behoren tot de middenklasse, heeft ieder een eigen agenda, één die niet noodzakelijkerwijs overeenkomt met die van anderen. De verantwoordelijkheid voor de ontwikkeling van suburbia raakt zo verspreid, over buitenwijkbewoners en overheden, ondernemingen en intellectuelen. Dat geldt niet alleen voor het prachtige ontwerp van planned suburbs, maar evenzeer voor de monotonie in tracts en de segregatie van blank en zwart, arm en rijk. ${ }^{125}$ Baxandall en Ewen werken in hun ontstaansgeschiedenis van suburbs op Long Island onder meer de samenwerking tussen republikeinse politici en private bouwondernemingen uit. In de jaren veertig en vijftig slaan conservatieve politici en grote projectontwikkelaars de handen ineen. Beiden willen af van een belangrijke erfenis van de New Deal, namelijk sociale woningbouw betaald door de overheid. In het congres, het gemeentehuis en de rechtbank, tijdens besprekingen met vakbonden en allerlei lobbygroepen - van makelaars en bankiers tot autofabrikanten en leveranciers van het beton voor snelwegen - en in verschillende media wordt gestreden om de parameters van de naoorlogse huizenmarkt. 'Modern private mass builders' komen als de grote winnaar uit de strijd - William Levitt wordt de Henry Ford van de woningbouw. Met zijn gestroomlijnde bouwmethoden, zijn gewiekste verkoop-en promotiestrategie en gesteund door allerlei overheidsmaatregelen komt hij model te staan voor de 'new corporate giants' die de macht naar zich toe trekken (zie Baxandall en Ewen (200o): hoofdstukken 8-10). In deze geschiedenis zijn het niet bewoners, maar bouwgiganten die de buitenwijk vormgeven - 'they changed the face of America seemingly overnight'(ibid: p. 123).

In Jacksons Crabgrass Frontier, tot slot, krijgt de verwezenlijking van het suburbane ideaal een wettelijk kader. Om te beginnen schetst Jackson een uitgebreide context waarin de middenklasse wel een rol van betekenis heeft, maar daaraan veel nadrukkelijker dan in 
bijvoorbeeld Fishmans geschiedenis invulling geeft te midden van allerlei maatschappelijke, economische, politieke en technologische ontwikkelingen. Jackson vraagt dan ook niet zoals Fishman naar de uitvinder van suburbia, maar schetst een geschiedenis van voorwaarden en oorzaken die de middenklasse onmogelijk onder controle heeft. Het Anglo-Amerikaanse suburbane ideaal dat in Bourgeois Utopias centraal staat, is in Crabgrass Frontier naast de sterke stedelijke bevolkingsgroei slechts een van de voorwaarden voor het ontstaan van de buitenwijk. Beide zijn belangrijk, maar kunnen de Amerikaanse suburbanisatie niet verklaren, betoogt Jackson. De oorzaken van de trek naar buiten zijn raciaal en economisch van aard. Ten eerste is er de diversiteit van de bevolking, in het bijzonder in de grote steden. Deze heterogeniteit vormt volgens Jackson voor veel stedelingen een belangrijke prikkel om de stad te verlaten. Blank is bang voor zwart. Belangrijker nog dan huidskleur is een aantal economische factoren, waaronder de relatief lage kosten van huisvesting in de Verenigde Staten. Daaraan draagt naast het relatief hoge inkomen per hoofd, de lage grondprijs, goedkoop vervoer en betaalbare constructiemethoden vooral het beleid van de overheid bij. Decennialang financiert en subsidieert ze uit algemene middelen voorzieningen waarvan met name de buitenwijkbewoner profiteert. Exemplarisch in Jacksons betoog is het beleid van de Home Owners Loan Corporation (HOLC) en de Federal Housing Administration (FHA).

De HoLc introduceert in 1933 de mogelijkheid een hypothecaire lening terug te betalen over een lange termijn, in gelijke bedragen voor de gehele duur van de lening. Ze ontwikkelt een methode om de bestaande en vooral toekomstige waarde van de huizen die ze helpt financieren in kaart te brengen. Op basis van de aard, leeftijd, prijs en kwaliteit van de huizen en de leeftijd, het inkomen en de etniciteit van bewoners onderscheidt ze vier categorieën buurten. Wijken scoren een A (en de kleur groen) als ze in goede en slechte tijden in trek zijn. Ze worden omschreven als nieuw en homogeen, waarbij homogeen staat voor 'American business and professional men'. B-wijken hebben hun piek bereikt, maar worden geacht nog jaren stabiel te blijven, wijken met label c verkeren in een proces van verval, D-wijken (roodgekleurd) zijn al vervallen. Nieuwe, blanke, welvarende suburbs worden in dit systeem het hoogst gewaar- 
deerd. Volle en oude wijken en wijken met een gemengde bevolking worden structureel ondergewaardeerd. Zwarte buurten krijgen zonder uitzondering etiket D opgeplakt, omdat ze als gevaarlijk te boek staan. Ze bieden te weinig zekerheden om in aanmerking te komen voor een ноцc-hypotheek (zie Jackson (1987): pp.195-203).

De Federal Housing Administration neemt deze discriminatoire methode van red lining over. De FHA is volgens Jackson een overheidsorgaan dat de Amerikaanse samenleving een halve eeuw lang diepgaand beïnvloedt. Samen met de Veterans Administration, bedoeld om zestien miljoen terugkerende soldaten na de Tweede Wereldoorlog aan een woning te helpen, biedt ze geldverstrekkers een overheidsgarantie, zodat deze zonder risico hypotheken kunnen verstrekken. Zo helpen ze tussen 1934 en 1972 ongeveer 35 miljoen gezinnen. Van de 119 miljard dollar die de FHA besteedt, gaat veruit het grootste deel naar de bouw van nieuwe buitenwijken. Oude centra en stadswijken worden veronachtzaamd. De voorkeur gaat uit naar de vrijstaande eengezinswoning, de bouw van appartementen wordt ontmoedigd. Daarnaast zijn leningen voor nieuwbouw groter dan die voor reparaties, waardoor het moderniseren van een oude woning duurder is dan het kopen van een nieuwe. Bovendien scoort de nieuwe, blanke suburb op de zogeheten Residential Security Maps veel hoger dan de oudere, drukkere en gemengde stadswijk. Met economische stabiliteit, sociale rust, etnische en raciale homogeniteit als wettelijke criteria steunt de FHA de facto de blanke middenklasse in de buitenwijk en laat ze arme en zwarte binnensteden aan hun lot over. De overheid, concludeert Jackson, verheft een discriminerende marktpraktijk tot publiek beleid (zie ibid: pp. 203-18).

In Bourgeois Utopias en Crabgrass Frontier slaat de balans van lot en wil heel anders uit. Jackson maakt korte metten met het idee dat de bloei van suburbia het resultaat is van 'free choices in an open environment' (ibid: p. 293). De meeste middenklassegezinnen zijn helemaal niet vrij om te kiezen tussen woonalternatieven. Het gevoerde beleid maakt dat slechts één optie financieel haalbaar is: suburbia. Naast de machtige projectontwikkelaar is het vooral de overheid die de middenklasse richting buitenwijk dirigeert. Betrekken we hierbij nog Jacksons stelling dat ideologie minder belangrijk is dan economic en dat het Anglo-Amerikaanse karakter minder invloed 
heeft dan technologische ontwikkeling en raciale relaties (zie ibid: p. 303), dan verdwijnen de eigenschappen en het waardestelsel die in Fishmans betoog de hoofdrol spelen, nog verder uit beeld.

\subsection{Weg suburbia, weg middenklasse}

Opmerkelijk genoeg verdwijnt ook in Fishmans betoog de middenklasse op een bepaald moment uit de geschiedenis. Los Angeles, schrijft hij in een bundel over die stad, lijkt even de definitieve uitdrukking van de Amerikaanse droom: universeel huizenbezit en autogebruik, goed betaalde banen en enerverende ontspanningsmogelijkheden in een groot gebied (zie Fishman (1996): p. 255). Even, want het bereikte evenwicht tussen stad en land blijkt fragiel. In de loop van de jaren zestig en zeventig stuiten stadsuitbreiding en de aanleg van nog meer snelwegen op hun grenzen. De open ruimte raakt opgevuld, de snelweg verstopt, de lucht vervuild (zie Fishman (1987): hoofdstuk 6). In Fishmans geschiedenis breekt een nieuwe fase aan. Daarin is het met de traditionele verhouding tussen stad en buitenwijk gedaan. Fishman begrijpt de afgelopen vijftig jaar niet als de culminatie van de geschiedenis van suburbia, maar juist als het einde daarvan. Hij interpreteert het naoorlogse grote bouwen niet als 'the suburbanization of the United States' de letterlijke ondertitel van Jacksons Crabgrass Frontier -, maar als het ontstaan van een nieuw soort stad. Noch stedelijk, noch ruraal, noch suburbaan in traditionele zin betekent de opkomst van dit nieuwe type omgeving een ontwikkeling 'beyond suburbia'. Waar de buitenwijk bijvoorbeeld functioneel afhankelijk was van de centrale stad, verbreekt de nieuwe technoburb de banden met de kern. En stimuleerde de groei van suburbia de ontwikkeling van gespecialiseerde diensten in de kern, de nieuwe periferie heeft deze niet meer nodig. Geleidelijk ontstaat een gedecentraliseerde metropolitane omgeving, een techno-city met alle economische en technologische dynamiek die we met de stad associëren (zie ibid: pp. 181-205).

De wijze waarop Fishman de neergang van suburbia inleidt, staat haaks op het perspectief waarmee hij in het eerste deel van zijn geschiedenis het ontstaan en de bloei van de buitenwijk opvoert. Dat de naoorlogse groei de balans verstoort, is onvermijdelijk, 
schrijft hij. 'Growth had become a giant machine operating out of control, creating endless expanses of development' (ibid: p. 179, cursivering $\mathrm{DH}$ ), voegt hij daaraan toe. Stedelijke uitbreiding is geen prestatie meer van een doelgericht handelende middenklasse, of welke andere ook. Ze is een machine die zelfstandig op volle toeren opereert en een proces in gang zet dat niet meer valt te beheersen. Waar Jackson projectontwikkelaars, investeerders, overheden en jonge middenklassegezinnen opvoert, verdwijnt in deze fase van Fishmans verhaal elke verwijzing naar de middenklasse, haar visie en handelingsbekwaamheid.

Op twee manieren wordt de vormgever van suburbia uit de geschiedenis weggeschreven. Ten eerste is er geen sprake meer van intenties en handelingen, maar van wat Fishman 'decentralizing tendencies of modern technology and society' (ibid: p. 189, cursivering $\mathrm{DH}$ ) noemt. Deze worden opgevoerd in tal van termen die min of meer als synoniemen functioneren. Het aantal is even groot als verwarrend. Er zijn bijvoorbeeld de 'underlying forces' en de 'remarkable power of "structures" in history', er zijn 'deeper economic trends' en 'deeper structural features of modern society' en 'deep patterns of economic and social necessity' (ibid: pp. 186, 189, 192 en Fishman (1988): p. 273, cursivering DH). Onduidelijk is onder meer of 'patronen' gelijk zijn aan 'tendensen' en 'trends' en hoe 'onderliggende krachten' zich verhouden tot 'structuren' en 'kenmerken'. Zijn ze synoniem, dan is een aantal termen overbodig. Zijn ze het niet, dan wordt niet helder wat elk precies toevoegt aan de reeks. Hiermee is niet gezegd dat deze veelheid aan begrippen in de vertelling geen functie heeft. Integendeel. Gezamenlijk hebben ze een sterk retorisch effect. Ze suggereren onontkoombaarheid, wekken de indruk dat waar voor het ontstaan van suburbia een duidelijke verantwoordelijke is aan te wijzen, de neergang onvermijdelijk is. Voor de opkomst van de techno-city zijn geen actoren nodig, geen doelstellingen en handelingen. Het aantal woningen groeit gestaag, maar niemand lijkt ze te bouwen en te kopen of zich er juist tegen te verzetten. Steeds meer bedrijven vestigen zich in de periferie, maar niemand lijkt daartoe, of daartegen, te beslissen. In een verklaring in termen van 'tendensen' en 'trends' is daarvoor geen plaats.

Waar toch melding wordt gemaakt van plannen, wensen en daden, worden hun effecten expliciet gebagatelliseerd. De 'deep pat- 
terns of economic and social necessity' opereren 'with little regard for individual plans or government initiatives' (Fishman (1987): p. 189). De technoburb ontstaat eerder ondanks dan dankzij geformuleerde doelstellingen, betoogt Fishman. Hij presenteert verschillende argumenten. Zo brengt de overheid bijvoorbeeld van alles teweeg 'without even knowing it', zoals ook de private sector lijdt aan 'unconsciousness' (Fishman (1988): p. 272). Voor zover wel 'bewust' beleid wordt nagestreefd, realiseert dat niet de gestelde doelen of sorteert het een averechts effect. Bovendien lijkt uit dergelijke onbedoelde gevolgen te worden afgeleid dat handelingen niet doelgericht waren of dat er überhaupt niet gehandeld werd. Ook op dit punt stapelt Fishman de termen op elkaar. 'Unplanned, unsought, and unanticipated, the new city is now a fact' (ibid: p. 273, cursivering DH). De werkelijke gevolgen van beleid zijn niet begrepen en de betekenis van 'diepere trends' is genegeerd. Weer is er een sterk retorisch effect. Dat 'niet gepland' en 'niet nagestreefd' van elkaar verschillen, dat beide bovendien iets anders betekenen dan 'niet anticiperen op' en dat alledrie weer iets anders inhouden dan 'niet begrijpen' en 'negeren' neemt niet weg dat deze termen gezamenlijk effectief suggereren dat de opkomst van de techno-city en haar -burbs met idealen en prestaties niets te maken heeft.

Fishmans betoog biedt een asymmetrisch verklaringsmodel. De buitenwijk bloeit op in een intentionele geschiedenis, in een structuurgeschiedenis vindt ze haar eind. Waar ze ontstaat als de 'residence of choice' van de middenklasse, wordt haar neergang ingeluid door 'the inherent forces in twentieth century technology and society' die 'asserted themselves to form a new pattern of urban life' (Fishman (1987): pp. xi, 189, cursivering DH). Wil wordt lot en voor wie zijn lot uit handen geeft is in deze versie van de geschiedenis kennelijk geen plaats. Waar het met suburbia gedaan is, verdwijnt de middenklasse van het toneel. ${ }^{126}$

4.4 Belangenverenigingen in postsuburbia

Fishmans vocabulaire staat in een traditie waarin wordt gesproken in termen van sprawl, een ontwikkeling waaruit een handelend subject is verdwenen. Al in 1963 is het volgens Robert Wood mode sub- 
urbanisatie niet te beschouwen als zomaar een fenomeen: 'the suburb does not simply appear on the scene; it "explodes", "mushrooms", and “sprawls"'(Wood (1963): p. 112). In 1974 heet groei in een artikel van Linda Greenhouse 'snow-balling, leap-frogging growth' (Greenhouse (1974): p. 289) en in Suburban Nation (2000) wordt gesproken van de architectonische versie van Invasion of the Body Snatchers: traditionele buurten worden vervangen door 'alien substitutes' - 'soulless subdivisions' als een bedreiging waarvoor niet is gekozen (zie Duany et al.(2001): pp.x, xiii).

Tegelijkertijd breekt Fishman met deze traditie. Waar meestal sprake is van een geleidelijk proces van uitbreiding, treedt in Bourgeois Utopias een breuk op. De gedecentraliseerde techno-city - of nonplace urban field zoals ze in 'The Post-War American Suburb' (1988) heet - heeft in deze geschiedenis geen antecedent. Ze wordt gepresenteerd als een radicaal nieuwe metropolitane vorm. ${ }^{127}$ Zo nieuw is $z e$ in andere versies van de geschiedenis niet. In hun inleiding van de bundel Postsuburban California (1991) schetsen Rob Kling, Spencer Olin en Mark Poster bijvoorbeeld een postsuburban formation, een omgeving die urbaan, ruraal noch suburbaan is, maar zich wel degelijk heeft ontwikkeld vanuit haar suburbane voorganger (zie Kling et al. (1991): pp. 5-6 en noot 12, p. 24). ${ }^{128}$ Ook Mark Baldassare benadrukt in Trouble in Paradise (1986) dat suburbia geleidelijk van karakter verandert. ${ }^{129}$ Hij spreekt van een suburban transformation die de buitenwijk eind twintigste, begin eenentwintigste eeuw voor nieuwe uitdagingen plaatst. In twintig jaar tijd is suburbia bijvoorbeeld een belangrijke vestigingsplaats geworden voor industrie en commercie. Zij hebben niet alleen behoefte aan hoogopgeleiden, maar bieden ook werk aan de lagere inkomens. Arbeiders trekken de periferie in, het werk achterna, maar steeds vaker ook om er te wonen. $\mathrm{Zij}$ vinden bijvoorbeeld onderdak in graying inner suburbs en soms in de verder weg gelegen naoorlogse tracts. Hoewel door allerlei maatregelen bepaalde gebieden nog steeds niet toegankelijk zijn voor etnische en raciale minderheden, trekken ook deze in steeds groteren getale naar buiten. Bovendien is de samenstelling van huishoudens veranderd. Het kerngezin is nog slechts een van de vele vormen. Ouderen willen kleiner gaan wonen of zoeken zorg in speciale appartementencomplexen, jongeren willen zelfstandig gaan wonen, maar kunnen de huizen niet meer betalen, en het aan- 
tal alleenstaanden stijgt snel, evenals het aantal tweeverdieners forenzen zijn allang niet meer alleen mannen.

Suburbia wordt zo op vele fronten heterogener: verschillend grondgebruik, verschillende klassen, etniciteiten, rassen en huishoudens. De blanke middenklasse woont in een veranderende omgeving en krijgt nieuwe buren en collega's. Dat de rollen door deze ontwikkelingen opnieuw worden verdeeld, wil geenszins zeggen dat het middenklassegezin als actor van het toneel verdwijnt. In sociologische, historische en vormgevingsstudies waarin geen radicale omslag plaatsheeft, maar ontwikkelingen stap voor stap veranderingen inhouden, blijft het op tal van manieren actief betrokken bij de vormgeving van de buitenwijk en de invulling van het bestaan daarin. Niet alleen blijven huizenbezitters als doe-het-zelvers hun woningen aanpassen, zij organiseren zich ook in belangenverenigingen die namens hen een soms verbeten sociaal-politieke strijd voeren om de aard van het suburbane bestaan.

In.W.D. Werberells 'The Man Who Loved Levivown' (wss) vertelt Tommy DiMaria over het gevoel samen met de buren iets tot stand te brengen. Hoewel het hier een fictioneel verhaal betreft, komen DiMaria's herinneringen zowel qua toon - nostalgisch - als bewoording - de dromen, de mogelijkheden, het pioniers- en doehet-zelfgevoel - overeen met die van de buitenwijkbewoners die bijvoorbeeld in Baxandall en Ewens studie worden geïnterviewd. Verschillend is de rijke symboliek die van DiMaria's herinneringen overduidelijk een terugblik maken in een literair verhaal. De leegte en de vergezichten worden breed uitgemeten, overal klinken hamers en geurt zaagsel, timmerlui werken met blote bast in de zon. Bovendien is er de tragedie die zorgt voor een spannende plot. In DiMaria's levensverhaal krijgen we een dynamisch suburbia te zien, waaraan gedurende ruim dertig jaar opeenvolgende bewoners een eigen invulling geven. Pioniers wisselen tips en gereedschap uit, vervolgens verruilen oude vrienden Levittown voor Florida en uiteindelijk zetten nieuwkomers de buurt naar hun hand. Zij eisen dat DiMaria zijn huis verkoopt. Als hij weigert, maken ze elkaar het leven zuur. DiMaria delft het onderspit. Maar in plaats van zijn huis, en daarmee de herinnering aan zijn overleden vrouw, zijn kinderen en oude buren, te verkopen, besluit hij het in brand te steken. Hij mag de strijd in de veranderende buitenwijk hebben verloren, 
een slapjanus is hij niet. 'I feel like I'm ready to find a new dream, raise a new family, the works,' rondt hij af. 'Nothing that's happened has made me change my mind. I'm ready to start again, just say the word. I feel stronger, more hopeful than ever (...)' (Wetherell (1985): p. 22). Hoewel de groep pioniers niet meer bestaat, maken DiMaria's herinneringen hem zelfs na al die jaren nog tot een strijdvaardige buitenwijkbewoner.

DiMaria ontwikkelt zich van een doe-het-zelver tot iemand die vecht voor zijn visie op het suburbane bestaan. Is het in zijn geval een individuele aangelegenheid, in veel andere organiseren buitenwijkbewoners zich om hun ideeën uit te dragen en hun belangen te verdedigen. In het veranderende suburbia van de afgelopen kwarteeuw spreken bewoners niet met één stem. Tussen de ideeën en belangen van cen manager die zijn bedrijf in een nieuwe edge city vestigt, die van suburbaniserende zwarte gezinnen en arbeiders en het traditionele blanke middenklassegezin kunnen grote verschillen bestaan. Zo vertellen de bewoners van suburbaan Long Island in Picture Windows over een complex en soms conflictueus bestaan, over een 'rich and stormy history' en een 'multilayered present' (Baxandall en Ewen (200o): pp. xvi, xvii). Aan het woord komen onder anderen lokale ambtenaren, makelaars, politieagenten, ouders, onderwijzers, advocaten, architecten, activisten, geestelijken en journalisten - jong en oud, rijk en arm, homo- en heteroseksueel, man en vrouw, gehuwd, gescheiden en alleenwonend, en afkomstig uit zowel de blanke, zwarte als Spaanstalige gemeenschap. Zelfs de leden van het blanke middenklassegezin onderling houden er levensstijlen op na die niet eenvoudig tot overeenstemming leiden. Het Populuxe-tijdperk is voorbij, besluit Hine zijn boek over de fifties en sixties bijvoorbeeld. Het gezin is niet meer gezamenlijk in de stationcar op weg naar de toekomst: 'Mom and Dad are divorced, the factory where dad worked moved to Taiwan, Sis is a corporate vice president, Junior is gay and Mom's a Moonie'(Hine(1999): p. 177).

Wat in Fishmans geschiedenis het einde van suburbia is, noemt Baldassare Trouble in Paradise. Veranderingen leveren in zijn betoog 'the new suburbia' (Baldassare (1986): p. viii) op. Soms lijken daarin net als bij Fishman niet-geplande en onbeheersbare processen de dienst uit te maken. Toch blijft er tussen termen als 'snelle groei' en 'industrialisatie' ruimte over voor afwegingen, beslissingen en da- 
den van individuen, groepen en bedrijven. Bedrijven kiezen bijvoorbeeld voor goedkopere grond en lagere belastingen. Lagere inkomensgroepen komen niet af op de belofte van homogeen wonen, maar op het aanbod van banen. En leden van de gevestigde middenklasse houden vast aan hun oude voorkeur voor bepaalde manieren van wonen en reizen, verliezen het vertrouwen in lokale overheden, hebben grote, soms overspannen verwachtingen van het leven in de buitenwijk en zijn bang voor snelle groei in het algemeen en daling van de kwaliteit van leven in het bijzonder (zie ook Baldassare's 'Suburban Communities' (1992)). Waar Baldassare impliciet een alternatief biedt voor Fishmans 'structuren' en 'tendensen', nemen Kling, Olin en Poster expliciet stelling. Postsuburbia is 'no accident'. Hoewel slechts 'weakly coordinated', is het een resultaat van 'complex (...) sets of conscious decisions by private entrepreneurs and many politicians who reflect their interests'. Verandering, is de stelling, treedt op 'through collective action stimulated by a small number of intentional agents rather than as evolving naturally like flowers' (Kling et al. (1991): pp. 10, 12-3, cursiveringen DH). Het gaat om 'interest-driven behavior' (ibid: p. 13) van belangrijke actoren als overheden en bedrijven, maar evenzeer activisten, belangengroepen en grass-roots social movements. In woord en daad bieden zij weerstand.

Talloze organisaties en coalities worden opgevoerd, elk met eigen opvattingen en belangen, elk op eigen wijze betrokken bij veranderingen in nieuw suburbia. In Picture Windows worden onder meer ontwikkelingen in Roosevelt en Freeport, Long Island vergeleken. In Roosevelt zaaien makelaars paniek door op slinkse manieren rassen en etniciteiten tegen elkaar uit te spelen. Ondanks dat leiders uit verschillende gemeenschappen zich hiertegen verzetten, is de suburb in de jaren tachtig arm en voor tachtig procent zwart. Freeport pareert de white flight met meer succes. Het kost de nodige conflicten tussen blank en zwart, jong en oud, liberalen en conservatieven, maar burgerorganisaties, een politieke coalitie van republikeinen en democraten, een door de gemeenschap gesubsidieerd makelaarskantoor en vrijwilligers krijgen uiteindelijk een multiculturele, integrated suburban community voor elkaar. ${ }^{130}$

Aan de andere kant van het continent binden in Mike Davis' Ecology of Fear (1998) weer andere partijen en coalities de strijd aan. Machtige groepen plukken er de vruchten van de sprawl - in de 
Davis kenmerkende vergrotende trap supersprawl - die de westkust teistert. Lokale overheden verkeren in de greep van de onroerendgoedbranche, county planning commissions worden neergezet als instrumenten van projectontwikkelaars, verenigingen van huiseigenaren ruziën met de brandweer, en milieugroeperingen zoals de Friends of the Santa Clara River zijn lokaal zeer actief, maar opereren te weinig op regionaal niveau. Bovendien raken diverse 'actoren' tegen wil en dank betrokken. In een polemisch spel vol retoriek en symboliek worden daklozen als brandstichters neergezet, wordt de stedelijke onderklasse getypeerd als 'predators', 'wilding youth' en 'wolf packs' in de 'urban wilderness' en worden roofdieren als de mountain lion op hun beurt afgeschilderd als 'serial killers' en 'gangbangers' (zie Davis (1998): hoofdstukken 2,3 en 5). Saai is het niet in deze postsuburban jungle.

In dit veranderd en nog steeds veranderend suburbia wachten betrokkenen hun lot niet af. Zowel oudgedienden als nieuwkomers verheffen hun stem. Ieder heeft eigen ọpvattingen, belangen en strategieèn en bovendien eigen herinneringen en verwachtingen. Met veranderende visies op het (post)suburbane bestaan krijgen veranderende temporele perspectieven gestalte. Lagere inkomensgroepen, zowel blank, zwart als Spaanstalig, zoeken in toenemende mate de periferie op in de hoop een baan en een betaalbare woning te vinden. Davis geeft het voorbeeld van L.A.'s San Fernando Valley. Ooit toonbeeld van blank suburbia - Ozzic-and-Harrict land in Davis' termen -, is de meerderheid er nu gekleurd. Er wonen alleen al meer dan een half miljoen recente immigranten, vooral Mexicanen. Velen zullen gedesillusioneerd raken, voorspelt Davis. 'What seemed from afar a promised land is, at closer sight, a low-rise version of the same old ghetto or barrio. Like a maddening mirage, good jobs and good schools are still a horizon away, in the new edge cities' (ibid: p. 405). De belofte lokt nieuwe suburbanisanten, maar trekt zelf verder.

De oorspronkelijke middenklasse voelt zich ondertussen steeds minder op haar gemak. Al sinds de jaren zeventig, schrijft Fred Siegel in The Future Once Happened Here (1997), streeft San Fernando Valley naar afscheiding van L.A.. De Valley-in Siegels termen het thuis van 'the forever seventies white-bread rv family, the Brady bunch'wil zeggenschap over wijkaangelegenheden en streeft naar een eigen quality-of-life policy, om de in gevaar gebrachte kwaliteit van 
het middenklasseleven te behoeden voor verder verval. De angst voor verval zit er al in de jaren zeventig goed in, betoogt Linda Greenhouse in haar bijdrage aan de bundel Suburbia in Transition (1974). 'Growth,' schrijft ze, '(...) that for so long held out to the suburbs the promise of an endlessly prosperous future, has suddenly developed into a shadow across that future' (Greenhouse (1974): p. 289). Groeit de bevolking in perifere gebieden, dan ontstaan daar als vanzelf nieuwe arme kernen; 'repositories for the infirm, the incapable, the unwanted' (ibid: p. 294). John Herbers geeft in dezelfde bundel aan wat het gevolg kan zijn: onrust, angst, frustratic en 'a deep sense of uneasiness about the future' (Herbers (1974): p. 283). De middenklasse voelt zich bedreigd, door zwarten uit arme stadswijken, drugs, criminaliteit, vervuiling, bevolkingsgroei, aanpassing van bestemmingsplannen en dalende huizenprijzen. Het gevolg is 'defensiveness, (...) a turning inward, a determination to shut out (...) decay and social upheavals (...), a fervid, participatory brand of politics that is fundamentally negative' (ibid: pp. 283-4). Men trekt zich terug, op verschillende wijzen. Wijken proberen zich formeel af te scheiden, weigeren belastingen af te dragen en houden er uiteenlopende vormen van restrictief beleid op na, van richtlijnen voor de minimumgrootte van percelen en huizen tot eisen aan de stijl daarvan. Bovendien scheiden ze zich in toenemende mate fysiek af van de omgeving. Er worden hekken gebouwd, camera's geïnstalleerd en bewakingsdiensten ingehuurd. Een groot aantal studies, met name in de sociologie en culturele geografie, bestcedt aandacht aan restricted access housing en zogeheten gated communities. ${ }^{131}$ Wie het zich kan veroorloven - voornamelijk de uppermiddle en upper class - verdedigt zijn belangen door zich van de omgeving af te schermen.

Of we dit nu beschouwen als verraad van het suburbane ideaal of als logisch uitvloeisel daarvan, of we het nu hebben over het inleveren van autonomie bij de voorzitter van de homeowners association, of over negatieve politiek, zich terugtrekken is een vorm van handelen. En met dat handelen krijgt een tijdperspectief uitdrukking. Van hoopvol de toekomst tegemoet treden, kunnen we nauwelijks meer spreken. Eerder streven welgestelden in toenemende mate krampachtig naar behoud van wat is vergaard. Geloof in vooruitgang wordt angst voor verval. ${ }^{132}$ 
 \\ Conclusie}

Doordat suburbia het strijdtoneel is waarop intellectuelen drie controversen uitvechten, vallen nogal uiteenlopende versies van de buitenwijk en haar bewoners te onderscheiden. Afgezet tegen het paradijselijke, pastorale en pittoreske ideaal stelt de suburb in de loop van de jaren vijftig en zestig heftig teleur. Angstig, afhankelijk en overmatig conformistisch, beschaamt de nieuwe middenklasse de belofte van wilskracht, autonomie en ondernemersgeest uit de frontier-traditie. Belangrijkste slachtoffer is het individu. Kritische buitenstaanders - of het nu onderzoekers zijn of literaire personages en vertellers - schetsen een suburbane dystopie waarin eigen inzichten en afwijkend gedrag onder de groepsdruk bezwijken. Zelfs als niet de groep, maar een eenling wordt uitgelicht, krijgen we niet een individu, maar een type te zien, een van de vele, nauwelijks van elkaar te onderscheiden gevangenen van suburbia.

Aanmerkelijk kleurrijker is het beeld waarin samen barbecuen en vergaderen over een nieuwe speeltuin een teken van sociale cohesie is en waarin een wagenwiel in de voortuin en een nieuwe Chevrolet Impala op de inrit uiting geven aan die bijzondere combinatie van nostalgie en ambitie. Een cruciaal verschil is dat de voor suburbia zo belangrijke consumptie in deze voorstelling niet het passieve genot is uit het dystopisch discours, maar juist een actieve invulling van het persoonlijke bestaan en het leven in de gemeenschap. De doe-het-zelver die in de bouwmarkt de nieuwste decoraties gaat halen, luidt niet als volgzaam kuddedier de dood van aloude idealen in, maar geeft als coproducent van de buitenwijk aan de Amerikaanse droom een eigen invulling.

Tot slot is het onderscheid tussen lot en wil een belangrijk ordenend principe. In de ene versie van de geschiedenis legt een wilskrachtige en handelingsbekwame middenklasse de basis voor de bloei van suburbia. Ze is de onbetwiste hoofdrolspeler, formuleert 
een ideaal en geeft daaraan eigenhandig vorm. In andere versies zijn haar mogelijkheden beperkt. Ze heeft over tal van ontwikkelingen geen controle, haar zelfredzaamheid wordt in twijfel getrokken, ze blijkt afhankelijk van verkeerslichten en riooltechnologie, belangengroepen houden er botsende agenda's op na en het beleid van de overheid legt haar keuzevrijheid danig aan banden. Breekt het einde van traditioneel suburbia aan, dan verdwijnt in de ene geschiedenis de middenklasse als handelende actor van het toneel. Trends, structuren, krachten en patronen hebben een techno-city tot gevolg. Voltrekt zich echter, veel geleidelijker, een suburban transformation, dan betekent een nieuwe positie van de middenklasse allerminst dat haar rol is uitgespeeld. Niet alleen timmert ze nog steeds net zo lang totdat een huis haar thuis wordt, ook vecht ze voor zeggenschap over de omgeving die dat thuis omringt. Op basis van uiteenlopende ideeën en strategieèn, herinneringen en verwachtingen zijn verschillende bewoners op eigen wijze betrokken bij veranderend (post)suburbia. Waar de één afkomt op een belofte, trekt de ander weg voor een bedreiging. Waar de één mogelijkheden ziet vooruitgang te boeken, vreest de ander een stap terug te moeten doen.

Ondanks het beperkte thematische en narratieve repertoire dat in hoofdstuk 2 werd onderscheiden, bestaan er onderling strijdige versies van de buitenwijk en haar inwoners. Zelfs als we erkennen dat sommige beelden hardnekkig standhouden en zelfs domineren, zolang we ons daarop niet blindstaren, vallen afhankelijk van wat commentatoren verwachten van het individu en van wat zij onder handelen en handelingsbekwaamheid verstaan, concurrerende versies van suburbia en zijn middenklasse aan te treffen. Het blijkt nogal wat uit te maken of hooggestemde idealen worden verkwanseld of bescheidener dromen worden verwezenlijkt, of consumptie wordt aangemerkt als kortzichtig hedonisme of juist als betekenisvolle uiting van terugblikken en vooruitzien, en of bewoners hun lot in eigen hand nemen of andermans wil krijgen opgelegd. Terugkerende thema's en motieven staan een rijk geschakeerd aanbod van beelden en vertellingen niet in de weg.

Dat aanbod is bovendien niet eenvoudig op te delen in wetenschap en literatuur, betoog en verhaal, feit en fictie. In sociologische studies brengen verteltechnieken en retorische trucs modellen tot 
leven en wekken fictionele impressies een realistische indruk. In sommige literaire verhalen is suburbia een illustratie bij een regelrechte aanklacht of een fictioneel sociologisch model, in andere vertelt een complex personage ons hoe het er in de buitenwijk 'werkelijk aan toegaat', maar leren we geleidelijk het niet op zijn woord te geloven. Op dit continuüm zijn etiketten als 'sociaal-wetenschappelijk' en 'literair' lastig te plakken. Betoog en verhaal staan niet eenvoudig tegenover elkaar. Betoog- en vertelstrategieẻn verschillen gradueel.

Waar de nadruk tot nu toe lag op wetenschappelijke studies, worden in de tweede helft van dit boek andere accenten gelegd. In hoofdstuk 5 staat Generation X (1991) van Douglas Coupland centraal, dat we als een literair verhaal kunnen lezen, maar dat ook een sociaal-wetenschappelijke context aandraagt. In hoofdstuk 6 volgt zijn 'Brentwood Notebook', dat nog lastiger valt te categoriseren. Eerst volgt in hoofdstuk 4 echter een interpretatie van twee romans. Voordat we kennismaken met Couplands zoekende postsuburbane jongelingen en trefzeker, gearriveerd Brentwood, ontmoeten we in John Updike's Rabbit, Run (1960) de laffe lower-middle-class Harry Angstrom en de ogenschijnlijk zo tevreden, maar o zo gespannen upper-middle-class stellen in Updike's Couples (1968). In beide romans krijgt met een bepaalde suburbane ruimte een identiteit en temporele oriěntatie gestalte. Twee verschillende buitenwijken vormen het decor voor geraffineerde suburbiakritiek, vergelijkbaar met die in sociaal- en geesteswetenschappelijke studies, maar toch daarvan verschillend. 
4

Bevrijd, maar benauwd

Geraffineerde kritiek in Updike's

Rabbit, Run en Couples 



\section{Inleiding}

Wordt van de middenklasse autonomie, visie en daadkracht verwacht, dan stellen Harry 'Rabbit' Angstrom en Piet Hanema hevig teleur. Moet in suburbia de combinatie van stabiliteit en vooruitgang, harmonie en competitie, terugblikken en vooruitzien tot uitdrukking komen, dan gaat in Mt. Judge en Tarbox een ideaal verloren. Zowel John Updike's Rabbit, Run (1960) als Couples (1968) is op te vatten als een proeve van suburbiakritiek, vergelijkbaar met die in veel teksten uit het vorige hoofdstuk. Maar achter die overeenkomst gaan interessante verschillen schuil. Beide romans schetsen opmerkelijke verbanden tussen de suburbane ruimte, de identiteit van haar bewoners en hun temporele oriëntatie. Dit hoofdstuk behandelt deze verbanden en de maatschappij-en cultuurkritiek die daarin zit verpakt.

Daartoe zal ik Rabbit, Run en Couples situeren te midden van zowel sociaal-wetenschappelijke als literaire teksten met een vergelijkbare thematiek. In die context gaat de aandacht uit naar het bijzondere van beide romans. Ik interpreteer ze door middel van 'een chronotopische leeswijze'. De 'chronotoop' is een concept dat is geïntroduceerd door de Russische literatuurwetenschapper en ideologiecriticus Mikhail Bakhtin om de verbeelding van tijd en ruimte te onderzoeken. Beide krijgen in de chronotoop gestalte, betoogt hij. Een gestalte waarin bovendien ook algemenere, vaak normatieve opvattingen doorschemeren, niet alleen over plaats en tijd, maar ook over identiteit - in dit geval die van de suburbane middenklasse. 


\section{Chronotopen in Rabbit, Run}

\subsection{Gevangenschap en ontsnapping als context}

Rabbit, Run is de eerste van tot nu toe vijf romans over het leven van Harry 'Rabbit' Angstrom. ${ }^{133}$ Tijdens zijn high school-tijd uitblinker als basketballer, leidt hij nu, in 1959, een middelmatig bestaan in lower-middle-class Mt. Judge, een buitenwijk van Brewer, Pennsylvania. ${ }^{134} \mathrm{Gedurende}$ een aantal maanden volgen we hem, in zijn leven thuis, maar vooral tijdens zijn pogingen om daaraan te ontsnappen. Harry werkt als verkoper van het keukenapparaat MagiPeel Peeler, zijn zwangere vrouw Janice Springer zorgt thuis voor hun zoontje Nelson. Als middentwintiger leidt Harry niet het bestaan waarop hij had gehoopt. Hij woont klein, Janice is labiel en drinkt om haar zorgen te vergeten en hijzelf loopt het liefst weg voor zijn verantwoordelijkheden als echtgenoot en vader. Op een dag tracht hij per auto te vluchten, maar een lange rit voert hem uiteindelijk terug naar Brewer. Via zijn oude basketbalcoach ontmoet hij Ruth Leonard, een prostituee bij wie hij een tijdje intrekt. In een poging zijn huwelijk te redden, schakelen zijn schoonouders een dominee in die hem moet overreden naar Janice terug te keren. Dat doet Rabbit nadat zij is bevallen van hun dochtertje Rebecca June. Even hoopt hij op een nieuwe impuls in hun relatie, maar al snel lopen de spanningen weer op. Harry gedraagt zich nog egoïstischer dan anders en laat Janice met hun twee kinderen alleen. Dronken laat zij Becky in bad verdrinken. Tijdens haar begrafenis wordt Harry verantwoordelijk gehouden, waarop hij reageert zoals hij altijd reageert: opnieuw rent hij weg. Ruth is de enige nog overgebleven bestemming. Zij blijkt zwanger van Harry en stelt hem voor de keuze. Of hij blijft bij Janice, of hij trouwt met haar. Rabbit kiest het hazenpad.

Harry's bestaan is een aaneenschakeling van krampachtige, tot 
mislukken gedoemde pogingen te voldoen aan tal van sociale verwachtingen en al even kansloze, want ongerichte, nauwelijks gearticuleerde pogingen daaraan te ontsnappen. In de context van hoofdstuk 3 is deze thematiek niet verrassend. In de jaren vijftig is het individu dat bezwijkt onder de sociale dwang tot aanpassing een terugkerende notie in zowel populaire media, literaire fictic als sociaal-wetenschappelijke studies. Met name Mills, Whyte en Riesman betreuren de teloorgang van individuele vrijheid en autonomie. Mills' onzekere Little Man is niet in staat zelf zijn leven richting te geven. Whyte's Organization Man laat zich leiden door een nieuw sociaal ethos dat sociale druk op het individu legitimeert en aanpassing en consensus tot norm verheft. Riesman valt other-directedness aan, een vorm van conformisme waarin het individu zich onderwerpt aan de meningen en verwachtingen van anderen om probleemloos te kunnen opgaan in de homogene buitenwijk. Eén van Riesmans erfgenamen in de jaren zestig is Dorothy Lee. In de buitenwijk, betoogt ze in 'Suburbia Reconsidered' (1963), ontbreekt het aan de diversiteit die nodig is wil het individu zich ontwikkelen tot een autonoom subject. Bovendien ontbreekt het er door een sterke hang naar harmonie aan conflicten die het individu helpen een eigen karakter te ontwikkelen. ${ }^{135}$

Wat betreft sociale druk, lijkt deze typering op het portret van Rabbits Mt. Judge. Van Harry wordt een gelukkig gezinsleven verwacht dat in harmonie verkeert met zijn omgeving. Bovendien dient hij carrière te maken, zodat hij zijn vrouw en kinderen meer kan bieden dan het kleine appartement aan Wilbur Street. Harry's situatie laat zich echter geenszins tot Lee's beeld reduceren. Sociale dwang noch monotonie resulteert in Mt. Judge in een conflictloos suburbaan bestaan. Integendeel. Harry laat zich niet in een keurslijf persen. Hij verzet zich, wat hem voortdurend in conflict brengt met zowat zijn hele omgeving. Waar het hem aan ontbreekt, is niet karakter - al heeft hij niet het karakter dat Lee zich wenst -, maar een heldere visie en vooral ruggengraat. Wist hij in zijn gloriedagen op een overvol basketbalveld het overzicht te bewaren, nu voelt hij zich al snel opgesloten en raakt hij onder druk in paniek.

Het gevoel gevangen te raken in een web van eisen en verwachtingen deelt Rabbit met tal van personages in romans en verhalen uit de jaren vijftig en zestig. Hoewel elk zijn eigen achtergrond en 
beweegredenen heeft en de buitenwijken waarin zij wonen verschillen, is hun verwantschap opvallend. Eenmaal in de suburb aangekomen, blijkt vertrekken niet eenvoudig. Met Tom en Betsy Rath maakten we in het eerste hoofdstuk kennis. Het echtpaar uit Wilsons The Man in the Grey Flannel Suit (1955) vreest zijn te kleine huis aan Greentree Avenue niet te kunnen verruilen voor een comfortabeler woning met minder kleinburgerlijke buren. Het huis brengt genadeloos hun zwakten aan het licht, menen Tom en Betsy. Het gazon ligt er haveloos bij, deuren zitten vol krassen, kranen druppelen, muren zijn vies of kapot en meubels moeten worden bekleed. In de loop van zeven jaar zijn de Raths hun huis gaan beschouwen als een val waaruit het niet gemakkelijk ontsnappen is: 'a trap, and they no more enjoyed refurbishing it than a prisoner would delight in shining up the bars of his cell' (Wilson (1956): p. 5). In Keats' The Crack in the Picture Window (1956) zit vooral Mary gevangen. Ze is gebonden aan een huis dat geen thuis is en een buurt zonder gemeen-

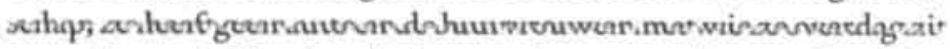
opgescheept, hebben het slechts over het poepgedrag van hun kinderen en de gebreken van hun mannen. 'Mary felt caught in a deadly trap. (...) And there was no way out' (Keats (1957): pp. 59, 64). ${ }^{136}$ Gevangen zitten ook de Wheelers in Yates' Revolutionary Road (1961). Frank heeft het over 'a Cellophane bag. It's like having been encased in some kind of Cellophane for years' (Yates (2001): pp. 129-30). Nu hebben we in het vorige hoofdstuk gezien dat we zijn woorden met een flinke korrel zout moeten nemen, maar we weten ook dat zijn vrouw April meent wat zij zegt. Ook zij spreekt van 'a trap' (ibid: p. 27). Volgens haar 'it's your very essence that's being stifled here. It's what you are that's being denied and denied and denied in this kind of life' (ibid: p. 115). ${ }^{137}$ De benauwdheid dreigt ook Francis Weed uit John Cheevers 'The Country Husband' (1967) te veel te worden. In het suburbane Shady Hill ziet hij zijn allerindividueelste verlangens aan banden gelegd. Routine en gewoonte worden er koste wat kost gewaarborgd, wat Weed bijna tot waanzin drijft. Een laatste gevangene is Arthur Douglas in Karps Leave Me Alone (1957). 'I have the feeling that we're being locked up, wrapped up, snuggled down, tucked in,' vertelt hij een collega, 'and what kills me is that everyone's so damned anxious to get inside, to get tucked in and wrapped up' (Karp (1965): p. 348). Zijn buren in Oakstown hebben 
misschien geen kwaad in de zin, maar dat maakt de druk die zij op hem uitoefenen niet minder groot. Arthur spreekt van een tirannie van goede bedoelingen. Juist die vriendelijkheid, meent hij, maakt verzet zo mocilijk.

Hoewel tussen deze buitenwijkbewoners grote verwantschap bestaat, vertonen hun reacties op suburbane gevangenschap en bedreiging van individualiteit, vrijheid en autonomie grote verschillen. Deze zijn interessant, omdat ze een context vormen waarin we Rabbits krampachtige handelen kunnen begrijpen. Arthur Douglas beseft hoezeer Eleanor en de kinderen het in Oakstown naar hun zin hebben en besluit te blijven. Wel stelt hij grenzen aan de mate waarin hij zich aanpast. 'There are things you don't adjust,' zegt hij tegen zijn vrouw. 'You just damn well leave them alone' (ibid: p. 344). Arthurs individualiteit blijft recht overeind. Francis Weeds lusten laten zich in Cheevers verhaal wel temmen. Hij raadpleegt een psychiater en steekt op diens aanraden de energie van zijn ongepaste verlangens in sociaal aanvaarde, zelfs toegejuichte doe-het-zelfactiviteiten. Slechts gestoken in een dergelijke dwangbuis kan hij de stabiliteit van zijn gezinsleven in Shady Hill redden. Frank en April redden het niet. Zij laat in haar strijd voor verandering het leven, hij verliest het laatste restje bezieling dat hem op de been hield. Uit kleine dingen blijkt dat Frank de geest heeft gegeven. Een slappe handdruk, overdreven zorg om de vouw in zijn broek, zijn pink voor de zekerheid onder een glas - wat er van Frank over is, is een 'walking, talking, smiling, lifeless man' (Yates (2001): p. 330$).{ }^{138}$ De Amerikaanse droom van Keats' Drones blijkt een nachtmerrie waaruit zij niet meer ontwaken. Zelfs nadat zij zijn verhuisd naar Merryland Dell, zijn zij niet verlost van de ellende in Rolling Knolls. Zij blijken voor hun oude huis te moeten blijven betalen, waardoor hun financiële situatie uitzichtloos wordt en hun lot in handen ligt van Mr. Catchpoll, van sов Suburban Bank and Trust. Symbolisch is het kaartje dat John aan het eind van het verhaal in zijn broekzak vindt: het is zijn levenslange abonnement op het zwembad van Rolling Knolls. Tom Rath, tot slot, mag dan door zowel Whyte en Riesman als Wilson zelf worden opgevoerd als een exemplarisch lid van de suburbane middenklasse, van hem zijn niettemin meerdere, zelfs strijdige typeringen mogelijk, afhankelijk van de personages waarmee we hem vergelijken. Vergeleken 
met de oude, conservatieve Parkington, is Tom een vooruitstrevende, vernieuwingsgezinde suburbanisant. Vergeleken met de slagvaardige projectontwikkelaar en self-made man Bugala, is hij de vertegenwoordiger van een suburbane middenklasse die o zo voorzichtig bescheiden plannen tracht te realiseren. Vergeleken met zijn vrouw Betsy, is hij een onzekere forens voor wie orde en regelmaat heilig zijn en in wiens vocabulaire 'risico nemen' niet voorkomt. Betsy valt nog het meest aan te merken als het daadkrachtige subject dat de moed heeft te werken aan een suburbaan ideaal. Terwijl zij vooruitkijkt, lijkt Tom slechts terug te blikken.

Net als Tom is Rabbit een onzekere jongeman, echtgenoot en vader die in een suburbaan middenklassemilieu probeert zijn bestaan op orde te krijgen. Dat kost hem grote moeite, mede doordat hij, net als Tom, zodanig gepreoccupeerd is met zijn verleden dat hem niet duidelijk wordt wat hij in de toekomst zou willen bereiken. Waar Tom er echter uiteindelijk in slaagt zijn blik vooruit te richten en samen met Betsy een eerste stap zet op weg naar realisatie van hun Amerikaanse droom, is Rabbits bestaan weinig meer dan een leven op de vlucht - in abstracte zin voor de sociale druk uit zijn omgeving, volwassenheid, beslissingen en verantwoordelijkheid; concreet voor zijn slechte huwelijk, zijn ouders en schoonouders en de problemen die hij met zijn gedrag steeds opnieuw helpt veroorzaken. Rent Harry aan het begin van de roman nog ergens naartoe, aan het eind rent hij enkel nog ergens vandaan.

\subsection{Het concept 'chronotoop'}

Om te bestuderen hoe dit leven op de vlucht in Rabbit, Run precies wordt verbeeld, maak ik gebruik van het concept 'chronotoop.'. ${ }^{139}$ Met dit concept introduceerde Bakhtin ook een bepaalde visie op en leeswijze van literatuur. Zijn werk is voor een groot deel gewijd aan de voortdurende strijd tussen discoursen om betekenissen, kwalificaties, waarderingen en veroordelingen. De Rus maakt zich sterk voor een diversiteit aan gezichtspunten. Hij pleit voor een dialoog waarin perspectieven met elkaar worden geconfronteerd, omdat deze helpt dominante visies aan het wankelen te brengen en alternatieven een kans geeft een voet aan de grond te krijgen. ${ }^{140}$ Een 
geschikte ontmoetingsplaats voor uiteenlopende gezichtspunten is volgens Bakhtin het literaire verhaal, in het bijzonder de roman. Bestaande opvattingen kunnen erin worden betwist en verdedigd en nieuwe gezichtspunten komen erin tot stand. ${ }^{141}$ Deze worden in de roman niet op abstracte en systematische wijze vergeleken, maar botsen tijdens concrete confrontaties tussen personages. Denkende, sprekende en handelende individuen belichamen gezichtspunten. In concrete situaties, op een specifieke plek en een specifiek moment, gedragen ze zich op een bepaalde manier, wisselen ze gedachten uit en geven daarmee vorm aan elkaars opvattingen en de wereld waarvan zij deel uitmaken. De kracht van literaire verhalen, betoogt Bakhtin, ligt in de 'density and concreteness' ((1998b): p. 250) waarmee dergelijke situaties worden verbeeld. Deze visie ligt dicht bij Rorty's, Nussbaums en Ricoeurs opvattingen over de meerwaarde van literatuur die in hoofdstuk 1 aan de orde kwamen. ${ }^{142}$ Bovendien voegt ze daaraan een leeswijze toe, of op zijn minst een aanzet daartoe. Hoewel Bakhtin niet expliciet een analysemethode voorstelt, kan zijn werk helpen Rabbit, Run - en Couplesop specifieke wijze te interpreteren. ${ }^{143} \mathrm{Het}$ onderlinge verband tussen ruimte, tijd en identiteit staat daarbij centraal.

Op een aantal manieren draagt de chronotoop - letterlijk 'tijdruimte' - bij aan de structuur van een verhaal en de verbeelding van gebeurtenissen, de identiteit van personages en hun tijdperspectief. Ten eerste fungeert hij als organisatiecentrum in de tekst. De chronotoop is een punt waarop belangrijke verhaallijnen samenkomen. 'The chronotope is the place where the knots of narrative are tied and untied,'schrijft Bakhtin ((1998b): p. 250). Hij helpt belangrijke gebeurtenissen onder te brengen in een narratieve structuur. De tweede functie van de chronotoop is hiermee nauw verbonden. Hij zorgt er niet alleen voor dat gebeurtenissen op een bepaalde plaats en een bepaald moment plaatshebben, maar vooral ook dat ze dan en daar tot leven komen. De chronotoop 'makes them take on flesh, causes blood to flow through their veins' (ibid). Hij structureert niet alleen het verhaal, maar vormt als plaats in de wereld die wordt opgeroepen tevens het centrum van concrete representatie. In verhalen over suburbia kunnen we bijvoorbeeld denken aan buitenwijken als geheel, specifieke huizen of kamers daarin, de tuin en de weg. ${ }^{144} \mathrm{Op}$ en rond dergelijke plaatsen krijgt bovendien een 
houding ten aanzien van tijd concrete uitdrukking. Een derde functie van de chronotoop heeft te maken met de materialisatie van tijd in ruimte. Op een duidelijk afgebakende plaats wordt tijd tastbaar en zichtbaar. 'Time, as it were, thickens, takes on flesh, becomes artistically visible,' schrijft Bakhtin (ibid: p. 84). Dat geldt zowel voor de temporele oriëntatie van het individu als voor die van de sociale groep waartoe het behoort en de samenleving en cultuur waarvan het deel uitmaakt - denk bijvoorbeeld aan de sociaal-economische verwachting van opwaartse mobiliteit waaraan de movingout parties in het Westport van de Raths uitdrukking geven.

De wijze waarop tijd en ruimte in de chronotoop verknoopt raken, is hecht verbonden met de identiteit van personages. Dit is de laatste functie die ik onderscheid. Bakhtin spreekt in dit verband van de 'fullness of time': een verleden dat een contingent heden oplevert en een heden met een open toekomst. Naast de fysieke omgeving draagt de betrokkenheid op alledrie bij aan de ontwikkeling van personages. De verbeelding van mensen in een literair verhaal, schrijft Bakhtin, is intrinsiek chronotopisch (zie ibid: p. 85). Uiteindelijk, stelt Pam Morris in The Bakhtin Reader (1994), gaat het hem daarom: het beeld van mensen in relatie tot hun ruimtelijke en temporele wereld (zie Morris (1994): p. 180). Dat beeld is vaak allerminst waardevrij. Het is doorspekt met emoties, oordelen en veroordelingen. In de chronotoop als plaats- en tijdbeeld krijgt een wereldbeeld uitdrukking of komen wereldbeelden bijeen, soms in harmonie, maar meestal niet. De chronotoop helpt niet alleen opvattingen en ervaringen van individuele personages te verbeelden, maar geeft ook uitdrukking aan algemener ideeën, bijvoorbeeld van een klasse of generatie over ontwikkelingen in hun maatschappelijke positie in een bepaalde periode. Ook 'the novel's abstract elements - philosophical and social generalizations, ideas, analyses of cause and effect - gravitate toward the chronotope,'schrijft Bakhtin ((1998b): p. 250).

\subsection{Een appartement en een web van wegen}

Een chronotopische lezing van Rabbit, Run levert een beeld op waarin Harry in kringetjes rondrent. Hij vlucht, maar kan niet ontsnap- 
pen. Als hij aan het begin van de roman naar huis rent, krijgen we een indruk van waar hij woont. Hij loopt de grote huizen voorbij en komt een straat in met kleine, slecht onderhouden appartementen in de kleur van stront en blauwe plekken. Eén daarvan is het zijne. De trap naar de voordeur is uitgesleten, eronder ligt modder die vanuit een hoger gelegen, nieuwere buurt zijn straat in loopt. Hier woont duidelijk niet het betere deel van de middenklasse. De sfeer binnenshuis is beklemmend. De voordeur zit op slot, de hal is donker en muf, de keuken is niet meer dan een nauwe doorgang tussen verouderde apparaten en in de kamer ziet Harry slechts rotzooi om zich heen, zoals ook zijn leven een puinhoop is. Hij lijkt de enige die verlangt naar orde. De kleine Nelson laat zijn speelgoed slingeren, Janice kijkt rokend en drinkend televisie. Een overvolle asbak, een verfomfaaid tapijt, oude kranten en pluizen onder de radiatoren: 'the continual crisscrossing mess - clings to his back like a tightening net'(Updike (1991a): p. 9). Uit dit net, dat nog in vele gedaanten zal opduiken, tracht Harry te ontsnappen. Tevergeefs, hij is er hopeloos in verstrikt. Angstig wacht hij het moment af waarop hij het in zijn appartement en huwelijk met Janice te benauwd krijgt. Hij kan met haar niet praten en het lijkt hem te irriteren dat zij zwanger is: 'something swelling inside is straining against her littleness' (ibid) - er is letterlijk sprake van onderhuidse spanningen. 'Rabbit (...) senses he is in a trap. It seems certain. He goes out'(ibid).

Zonder vluchtplan, zowel qua route als bestemming, rijdt Harry naar het zuiden. Een geïdealiseerd zuiden, met vrouwen die blootsvoets door sinaasappelplantages en langs dampende rivieren dwalen, dat hij niet zal bereiken. Wegen voeren hem voortdurend in andere richtingen. Waar zij als belangrijke chronotoop in veel romans en verhalen nieuwe perspectieven openen, interessante ontmoetingen opleveren en aan levens een nieuwe wending geven, leiden ze Rabbit onontkoombaar naar de plaats van vertrek. Ze sluiten hem op. De bomen langs de route lijken hem met hun takken in te sluiten en het ontbreekt aan borden die een uitweg zouden kunnen bieden. Zelfs zijn wegenkaart wijst hem niet de goede richting. Haar veelkleurige lijnen, vierkanten, cirkels en lange namen houden hem gevangen. ${ }^{145}$ Hoewel hij een hele afstand aflegt, is Harry uiteindelijk terug bij af. Ook geestelijk boekt hij geen enkele vooruitgang. In plaats van thuis orde op zaken te stellen door een beslis- 
sing te nemen over de toekomst van zijn huwelijksleven en zijn saaie, uitzichtloze bestaan in Mt. Judge weigert Harry concrete stappen te ondernemen. Hij is daartoe eenvoudig niet in staat. Hij zoekt zijn toevlucht in een herhaling van zetten, deze keer niet door te vertrekken, maar door 'thuis' te blijven en heen en weer te pendelen binnen een zeer beperkte sociale kring.

\subsection{Een sociaal circuit}

Omdat hij zijn familie niet wil zien en omdat hij verder geen vrienden heeft, zoekt Rabbit zijn oude basketbalcoach op. In zijn auto wacht hij hem op. Paniekerig, omdat hij het gevoel heeft dat zijn familie en wellicht de politie jacht op hem maakt - 'a net of telephone calls ${ }^{146}$ and hasty trips, trails of tears and strings of words, white worried threads (...), an invisible net overlaying the steep streets and in whose center he lies (...) in his locked hollow hutch' (ibid: p. 24). Zijn oude coach blijkt, zoals zijn naam Tothero doet vermoeden, aan lager wal geraakt en heeft Rabbit buiten herinneringen aan zijn basketbalverleden niets te bieden. Wel leert Harry via hem Ruth kennen, met wie hij naar bed gaat en bij wie hij vervolgens intrekt. In haar woning lijkt Harry zich even met succes te onttrekken aan zijn verantwoordelijkheden en blijft hij tijdelijk uit handen van zijn woedende schoonouders. Zo gauw hij zijn schuilplaats echter verlaat om thuis stiekem wat spullen op te halen, zijn zij hem op het spoor. Als een geduldig belager patrouilleert de dominee die zij hebben ingeschakeld door de straten rond Harry's appartement. Eccles weet Rabbit op te vangen nog voordat hij kans ziet (weer) weg te rennen. Harry schudt hem de hand en weet onmiddellijk hoe laat het is. 'For an instant Rabbit fears he will never let go. He feels caught, foresees explanations, embarrassments, prayers, reconciliations rising up like dank walls; his skin prickles in desperation. He feels tenacity in his captor'(ibid: p. 59).

Eccles laat zijn greep niet verslappen. Nadat Harry zijn adviezen in de wind blijkt te slaan, speelt hij geraffineerd in op diens zwak voor het spel. Wetend dat Harry een spelletje zal verkiezen boven de problematische werkelijkheid, nodigt hij hem uit voor een partijtje golf. Tijdens hun gang langs de holes blijkt Rabbit gedreven door 
een diep, maar nauwelijks gearticuleerd verlangen naar een teken van een God op wie hij kan vertrouwen. ${ }^{47}$ Hij toont zich een veel geloviger man dan de dominee - net als coach Tothero is Eccles niet de leidsman die zijn leven zin en richting kan geven. Hij beperkt zich tot de taak waarvoor hij is ingehuurd en weet Harry steeds verder in te kapselen in voorstellen en raadgevingen, alle vertalingen van Janice' wensen en de eisen van haar ouders. Als Harry na ruim twee maanden Ruth verlaat voor Janice raakt hij opnieuw verstrikt in het web dat zij voor hem hebben gesponnen. Hoewel hij aanvankelijk denkt zowel letterlijk als overdrachtelijk de juiste, rechte weg te hebben gevonden (zie onder meer ibid: pp. 119, 121), blijkt deze hem slechts terug te voeren naar hetzelfde, enge kringetje waaraan hij trachtte te ontsnappen. Hij pendelt heen en weer tussen het zickenhuis waar zijn vrouw en dochtertje Rebecca June verblijven, Eccles' huis, zijn eigen appartement, de woningen van zijn ouders en schoonouders en het bedrijf waar hij inmiddels voor Janice' vader tweedehands auto's verkoopt. Deze plaatsen en mensen vormen het netwerk waarbinnen hij zich kan bewegen en waarbuiten hij geen sociale contacten heeft. Het idee opnieuw opgesloten te zijn, blijft dan ook niet uit. Achtereenvolgens bekruipt Harry het gevoel onder water vast te zitten in stugge slijmdraden ${ }^{148}$, levend in een doodskist te liggen, met te veel mensen in een te kleine ruimte opeengepakt te zijn en in zijn eigen huis opgesloten te zitten - 'inside the apartment, whose walls sweat like the walls of a prison' (ibid:p. 141$) \cdot{ }^{149}$

Nadat Harry Janice bruut heeft duidelijk gemaakt dat alleen telt wat hij voelt, vertrekt hij opnieuw. Doelloos zwerft hij rond in Brewer, tevergeefs op zoek naar een opening. Tijdens Harry's afwezigheid verdrinkt baby Becky, waardoor hij noodgedwongen terugkeert in de familiekring. Harry wordt verantwoordelijk gehouden, wat hij aanvankelijk aanvaardt, al is het alleen maar omdat hij, ondergedompeld in haat, een excuus heeft om geen beslissingen te nemen en niet te handelen. ${ }^{150}$ Tijdens de begrafenis echter wordt de druk hem te groot en wijst hij Janice als schuldige aan. Hoewel vanuit zijn perspectief niet onbegrijpelijk, is een tactlozer optreden op dat moment nauwelijks denkbaar. Na zijn mislukte poging naar het zuiden te vluchten en na een tijdje als een kip zonder kop in kleine kring te hebben rondgerend, staat Harry helemaal alleen. 
'He turns and runs' (ibid: p. 17o), voor de zoveelste keer. De enige die nog met hem in discussie wil treden, is Ruth. Ook zij moet niets meer van hem hebben, maar als alleenstaande, zwangere vrouw is ze afhankelijk van hem. Ze noemt hem egoïstisch, kortzichtig, besluiteloos en slap. Vechtend tegen haar emoties, dwingt ze hem te kiezen tussen haar en Janice. Daarmee eist ze van Harry het onmogelijke, namelijk een keuze te maken en ernaar te handelen. Dat zij zich zo beheerst, zichzelf zo onder controle heeft, staat Harry tegen - 'he doesn't like people who manage things. He likes things to happen of themselves' (ibid: p. 176). Dat Ruth hem voor het blok zet, maakt hem zenuwachtig. Hij zegt een broodje te gaan halen, maar met elke stap wordt de kans dat hij terugkeert kleiner. Voor Rabbit is lopen uitstellen. Hij weegt af: 'the right way and the good way, the way to the delicatessen (...) and the other way, down Summer Street to where the city ends' (ibid: p. 177). Hij tracht zich voor te stellen waarin deze paden, zijn keuzen, uitmonden: 'he doesn't know. He pictures a huge vacant field of cinders and his heart goes hollow' (ibid). Een verlaten sintelveld als enig overgebleven bestemming, een leegte die rust op resten. Harry keert zich naar binnen, voelt hoe hij begint te lopen:

around the block, to clear his head and pick his path. (...) He feels his inside as very real suddenly, a pure open space in the middle of a dense net. I don't know, he kept telling Ruth; he doesn't know, what to do, where to go, what will happen, the thought that he doesn't know seems to make him infinitely small and impossible to capture. His smallness fills him like a vastness. It's like when they heard you were great and put two men on you and no matter which way you turned you bumped into one of them and the only thing to do was pass. So you passed and the ball belonged to the others and your hands were empty and the men on you looked foolish because in effect there was nobody there(ibid).

Wie met de bal het initiatief uit handen geeft, is er even niet. Rabbit rondt het blok niet af, maar loopt door, loopt weg. Hij besluit niet te gaan rennen-dat komt doordat hij struikelt. 'His hands lift of their 
own (...), his heels hitting heavily on the pavement at first but with an effortless gathering out of a kind of sweet panic growing lighter and quicker and quieter, he runs. Ah: runs. Runs'(ibid).

\subsection{Een neerwaartse spiraal}

In deze chronotopische interpretatie - geconcentreerd rond Rabbits steeds kleinere kringetjes - betekent rondrennen: beweging zonder vooruit te komen. Harry laat zich voortdurend heen en weer slingeren tussen zijn eigen verlangens en de eisen en verwachtingen van zijn omgeving. Hij slaagt er niet in te ontkomen en kan ook niet aarden. Niet in zijn te kleine appartement dat hem dwingt tot de zenuwslopende togetherness die we uit het vorige hoofdstuk kennen. Niet in een Mt. Judge waarin televisie en reclame de enige vormen van afleiding zijn. Niet in de lagere middenklasse die hem met haar kleinburgerlijke moraal aan banden legt. Bekende schurken, stelt Dean Doner in 'Rabbit Angstrom's Unseen World', maar door Updike minutieus en angstaanjagend neergezet (zie Doner (1979): p. 18). Ook Clinton Burhans Jr. beschouwt Harry's rusteloosheid als een laveren tussen voldoen aan verwachtingen en verzet daartegen. In 'Things Falling Apart' (1982) rijgt Burhans Harry's cirkelbewegingen aaneen, zodat we ze als een spiraal kunnen opvatten. Doordat zijn omgeving hem niet de richting wijst die hij zo nodig heeft, richt Harry zijn blik steeds meer naar binnen. Elke volgende cirkel is zodoende kleiner dan de vorige en doordat uiteindelijk alleen nog egoïsme rest, blijft zijn eigen erbarmelijke leegte als enige bestemming over (zie Burhans (1982): pp. 152-6o). Zo beschouwd, dragen het appartement en het stelsel van wegen, het sociale circuit en Harry's solipsistische verdwijnpunt niet alleen als fysieke plaatsen in en rond Mt. Judge bij aan de verbeelding van Harry's toenemende benauwdheid, maar evenzeer als organisatiecentra in de structuur van de vertelling. Ze vormen een naar binnen gerichte beweging die het centrale thema van de beklemming ook in de narratieve structuur nadrukkelijk aanwezig stelt.

Opgevat als chronotopen zetten de drie kringetjes Rabbits bewegingen neer als een verandering zonder ontwikkeling. In geen enkel opzicht voldoet Harry aan de verwachtingen uit zijn omgeving. 
Persoonlijke groei maakt hij niet door. Hij wil maar niet volwassen worden, loopt letterlijk en figuurlijk weg voor zijn verantwoordelijkheden. Ook in sociaal-economisch opzicht stelt hij teleur. Zijn gezinsleven ligt overhoop, zijn relatie met familieleden ontwikkelt zich van kwaad tot erger en buiten hen heeft hij niemand. Zijn werk veracht hij en hoewel zijn baantje in pa Springers autobedrijf een beetje zekerheid biedt, lijkt een carrière er niet in te zitten, waarmee comfortabeler wonen een illusie blijft. Bovendien lijkt hij niet meer te passen in de Amerikaanse cultuur waarin hij vroeger een sportheld kon zijn. 'Is it just these people I'm outside, or is it all America?'(Updike (1991a): p. 20) vraagt hij zich vertwijfeld af.

Rabbit slaagt er niet in zich een doel te stellen en het initiatief te nemen om dit te realiseren. $\mathrm{Zijn}$ temporele oriëntatie stelt hem niet in staat een Amerikaanse droom te vervullen. Voortdurend is hij op de vlucht voor een problematisch heden. Zijn ondoordachte, kortzichtige gedrag maakt de puinhoop in zijn dagelijks bestaan alleen maar groter. Een duidelijke toekomstvisie heeft hij niet. Hij heeft geen idee wat hij zou willen bereiken, noch hoe hij daaraan zou moeten werken, wat hem stuurloos maakt. Dat zijn vluchtpogingen hierdoor gedoemd zijn te mislukken, wordt hem al tijdens zijn eerste lange autorit duidelijk gemaakt. 'The only way to get somewhere, you know,' vertelt een pompbediende hem, 'is to figure out where you're going before you go there' (ibid: p. 17). De enige plek waar Rabbit op zijn plaats is, is het basketbalveld uit zijn jeugd. In een spel dus, niet de realiteit. En in een verleden dat onherroepelijk voorbij is. Op tal van momenten gaan Rabbits gedachten terug naar zijn gloriedagen. Hij verliest zich in deze herinneringen, verschuilt zich erin, wat iets anders is dan het verleden een plaats geven om vooruit te kunnen. ${ }^{151}$ Soms lijkt hij dat maar al te goed te beseffen, maar inzien hoe het ervoor staat en daarnaar handelen, blijken voor Harry gescheiden zaken. Wat hem bij sommigen aanvankelijk nog geliefd maakt - zijn jongensachtige uitstraling en een onbeholpen enthousiasme voor het spel bijvoorbeeld - verwordt gestaag tot onverbloemd egocentrisch en steeds destructiever gedrag. In Rabbit, Run maken we kennis met een inwoner van suburbia wiens leven geen opgaande lijn laat zien, maar een spiraal - in het licht van de verwachtingen van groei en opwaartse mobiliteit een neerwaartse spiraal. 


\section{Een oordeel zonder veroordeling}

Naast temporele oriëntatie en identiteit krijgen in en rond chronotopen ook abstracter ideeẻn uitdrukking. Rabbit, Run is niet alleen te lezen als een portret van een man die ontloopt wat hem dreigt vast te pinnen, maar evenzeer als een beeld van een bepaald milieu in cen bepaalde samenleving en cultuur: het bestaan in een blanke, lower-middle-class suburb aan de Amerikaanse oostkust onder Eisenhower. In het kleine vinden we het grote gerepresenteerd. In Harry en Janice' huwelijk de schaduwzijde van het gezinsleven in de jaren vijftig, in de kritiek van Janice' moeder de normbiografie waaraan bijvoorbeeld ook Tom en Betsy Rath trachten te voldoen, in de woning van Harry's schoonouders materialisme en sociale pretenties. Als we de literatuurkritiek erop nalezen, wordt deze lijst snel langer. Rabbit, Run stelt de relatie tussen man en vrouw en jong en oud aan de orde, gaat over onverantwoordelijkheid, normvervaging, het gebrekkig functioneren van sociale instituties als school en kerk en, nog algemener, de Amerikaanse mythen rond geluk en succes en de gevolgen van een humanistische veronachtzaming van het spirituele. Een hele reeks, gebaseerd op interpretaties van Updike's roman die elkaar eerder aanvullen dan uitsluiten. ${ }^{152}$

Rabbit, Run is verschillend getypeerd - als groteske allegorie, als eenduidige maatschappij- en cultuurkritiek en als een kritische analyse die nog het meest weg heeft van een sociaal- en geesteswetenschappelijke studie: 'an almost dispassionate inquiry, an effort (...) to combine contemporary experience and observation with historical analysis and explanation'. ${ }^{153}$ Dat in de roman een kritisch beeld wordt neergezet, lijdt geen twijfel. Maar daarmee is de vraag hoe deze kritiek gestalte krijgt - en hoe ze zich van andere commentaren op de buitenwijk onderscheidt - nog niet beantwoord. Ik besluit mijn interpretatie met twee antwoorden op deze vraag.

Een eerste antwoord ligt in het verlengde van de drie chronoto- 
pen die Rabbits benauwdheid en behoefte aan een opening concreet helpen maken. Rabbit, Run, betoogt Richard Gilman in 'An Image of Precarious Life'(1979), biedt geen 'conclusion you can put on a shelf. Er is geen sprake van 'tying neat knots, offering explanations, coming up with big solid counterweights to the miseries of life' (Gilman (1979): p. 13). De roman biedt geen generalisaties of verklaringen in de vorm van een betoog dat van rafelranden is ontdaan. Integendeel. Juist de talloze details - sommigen spreken van grote precisie, anderen van overkill ${ }^{154}$ - maken Rabbits behoefte aan ontsnapping uit Mt. Judge en de mislukking van zijn pogingen daartoe zo overtuigend. De rotzooi in zijn appartement, het net iets te volle interieur van zijn schoonouders ${ }^{155}$, de koude-oorlogstactieken van Janice' moeder, de lijnen op de wegenkaart, de takken langs de route - samen vormen ze letterlijk het kader waarbinnen Harry zich moet zien te bewegen. Op een schier eindeloze reeks alledaagse problemen en frustraties volgt nergens een verklaring of generalisatic die zou kunnen dienen als eindpunt van reflectie of begin van een oplbssing. H'tet verstrikt zijn in een overmaat aan eisen en verwachtingen en de verlammende stuurloosheid door het gebrek aan eigen visie kan op geen enkel moment als een abstracte kwestie terzijde worden geschoven. Steeds is sprake van een acuut probleem. ${ }^{156}$

De indruk van beklemming wordt bovendien versterkt door de structuur die ik hierboven als een neerwaartse spiraal heb gekarakteriseerd. Rabbits laatste bewegingen zijn letterlijk egocentrisch. Nog verder dan voorheen keert hij zich naar binnen. Bovenal houdt dit in dat Rabbit nog een laatste keer weigert afstand te nemen, te reflecteren. Nog een laatste keer wijst hij de mogelijkheid af zijn problemen in een bredere context te beschouwen. Waar Mills, Whyte en Riesman de sociale druk op het individu analyseren en kritiseren in het licht van uitgesproken idealen, zoals autonoom ondernemerschap, streeft Harry ernaar elke vergelijking met andere opvattingen dan de zijne onmogelijk te maken. Waar Lee beschikt over een rijk vocabulaire om haar ideale subject in uit te drukken - 'so that an individual can exercise his powers of perception and discrimination in the area of making a choice, so that in making his own choice he can be an agent in creating his own experience' (Lee (1963): p. 124)-, verbeeldt Rabbit, Run uiteindelijk een mislukking zonder de toetssteen te expliciteren, wat de kans op een uitweg alleen nog maar kleiner maakt. 
Dit laatste heeft alles te maken met de focalisatie in Rabbit, Run. Daarin kunnen we een tweede antwoord vinden op de vraag hoe in deze roman kritiek gestalte krijgt. Mt. Judge is grotendeels Harry's Mt. Judge. Als belangrijkste focalisator vormt wat hij ziet en denkt de belangrijkste ingang tot het bestaan in deze buitenwijk. Tot op zekere hoogte is Harry analytisch, waardoor we veel over hemzelf en zijn omgeving te weten komen. Tegelijkertijd vertoont zijn analyse tal van beperkingen. Ten eerste resulteren zijn egocentrisme en beperkte sociale intelligentie in de nodige blikvernauwing. Zelden is hij bereid zich in te leven in de mensen om hem heen, waardoor hij zichzelf kan voorhouden dat $h i j$ het slachtoffer is, niet anderen. Ten tweede is er zijn onvermogen te verklaren wat hem overkomt. Hij reageert impulsief en gaat zelfs na gemaakte overwegingen af op zijn intuìtie. Hij signaleert tal van problemen, maar is niet in staat oorzaak en gevolg helder te onderscheiden. Harry komt niet tot een expliciete kritiek op het leven in Mt. Judge.

Rabbit is niet de enige die focaliseert. Allereerst is er de verteller. Hoewel deze nergens op de voorgrond treedt, beperkt hij zich niet tot situatie- en achtergrondschetsen. In tal van passages neemt de verteller op een subtiele manier herinneringen, waarnemingen en gedachten van personages over. Een personage heeft bijvoorbeeld vroeger iets ervaren, maar zou het zich dat op dit moment zo nauwkeurig herinneren? Het kijkt binnenshuis rond, maar bekijkt het al die dagelijkse dingen zo gedetailleerd? Een gedachte kan kenmerkend zijn voor een personage, maar zo ver doorgevoerd, met zoveel zelfreflectie? De verteller denkt mee en denkt door en draagt daarmee bij aan het beeld van het leven in deze buitenwijk. Dat beeld is bij vlagen ontnuchterend. Het stelt Mt. Judge voor als een plaats waar ervaringen ver achterblijven bij verwachtingen. Het leven is er allerminst aantrekkelijk.

Daarnaast zijn er Janice en Ruth. Zij zijn meer dan wil-en gedachteloze slachtoffers. Hun ervaringen wijken af van die van Harry en hun kijk op de zaken werpt een nieuw licht op zijn gedrag en opvattingen. Dramatisch is bijvoorbeeld Janice' ervaring van de verdrinkingsdood van haar dochtertje. Janice zinkt dieper dan Harry voor mogelijk houdt, wat zijn zoveelste vluchtpoging in een schril daglicht plaatst. Met Ruth delen we haar ambivalente gevoelens voor Harry. Ze walgt van hem en voelt zich tot hem aangetrokken. Haar 
Harry is geen echtgenoot, zoon of schoonzoon, maar een even onbetrouwbare als charmante minnaar. Bovendien bekijken we de problematiek in Mt. Judge door dominee Eccles' ogen. Zijn blik is die van een betrokken buitenstaander. Naast Harry's eigen gedachten zijn het vooral de zijne die Harry's situatie begrijpelijk maken. In veel opzichten bevestigt Eccles' visie die van Harry. Rabbit mag bij vlagen zeer onsympathiek, egocentrisch en tactloos zijn, volgens de dominee is hij niet de boeman waarvoor bijvoorbeeld Janice' moeder hem verslijt. Mochten we twijfelen aan Rabbits vermogen tot zelfreflectie, dan kunnen we bij Eccles terecht voor een aanvulling of correctie. ${ }^{157}$ Ook Janice', Ruths en Eccles' beelden van de wijk en van elkaar zijn onmogelijk objectief, samen leveren ze wel een schets op die allerminst eenzijdig is. Mt. Judge komt er nauwelijks beter vanaf, Harry zelf kan ondanks alles op de nodige sympathie rekenen.

In Rabbit, Run wordt over lower-middle-class Mt. Judge wel degelijk een oordeel geveld, maar in tegenstelling tot bijvoorbeeld Keats' cynische The Crack in the Picture Window of Yates' sarcastische Revolutionary Road mondt dit oordeel niet uit in een veroordeling. Begrip van Rabbits omstandigheden en twijfels verleidt de lezer tot een poging begrip op te brengen voor de manier waarop hij zich tracht staande te houden, ook al is dat op de loop. ${ }^{158}$ Rabbit, Run biedt impliciet kritiek, maar vraagt eveneens om compassie. Dat is iets anders dan medelijden. Waar Mills zijn Little Man eerder 'pitiful than tragic' noemt, is Rabbit eerder tragisch dan meelijwekkend. 


\section{4 \\ Chronotopen in Couples}

Zelden is een romanpersonage zo verschillend ontvangen als Rabbit Angstrom. Hij is een absurde heilige genoemd en een symbool van hoop in een beklemmende wereld, maar ook een onverantwoordelijke zwakkeling, een ziekelijke afspiegeling van een zieke wereld, een twintigste-eeuwse sub-man, een asociaal misbaksel, een seksist en - vooral naar aanleiding van latere romans uit de cyclus een xenofoob en racist. Rabbit spreekt tot de verbeelding, of we nu willen of niet. Hij maakt veel tongen los, dwingt tot stellingname in een voortdurende dialoog. Daarin gaat het niet slechts over Rabbit als enkeling, maar evenzeer over een sociaal milieu en een cultuur op een bepaalde plaats, in een bepaalde tijd. Het gaat om middleAmerica, specifieker om wat David Thorburn in 'Alive in a Place and Time' (1979) omschrijft als 'the spiritual and communal enfeeblement of contemporary American society, particularly among the suburban middle class' (Thorburn (1979): p. 4). In dit opzicht is Couples' portret van de suburbane gemeenschap in het Tarbox van 1963 sterk verwant aan het Mt. Judge uit Rabbit, Run. Wederom lopen de meningen uiteen. De één typeert Couples als een psychopathologie van het dagelijks leven, de ander spreekt van een 'a loving portrait of life in America' (zie respectievelijk Eiland (1979): p. 70 en Updike (1976): p. 497). Een aantal thema's keert terug: onvermogen of onwil te voldoen aan sociale verwachtingen, een gebrekkige zeggenschap over het verloop van het eigen leven én een gemakkelijk verstoord evenwicht tussen de behoeften aan geborgenheid en verandering. Bovendien blijkt ook in Couples de ideale combinatie van terugblikken en vooruitzien uitermate problematisch en is het hoofdpersonage Piet Hanema eerder een gedesoriënteerde, twijfelende buitenwijkbewoner dan het autonome, visionaire en daadkrachtige subject uit hoofdstukken 2 en 3 .

Waar we Rabbit, Run echter kunnen lezen als een impliciete kri- 
tiek op het leven in een buitenwijk, velt Couples een expliciet oordeel. De roman laat zich lezen als een verbeelding van de mislukking van een suburbaan ideaal, een ideaal dat door de tijd is ingehaald. Niet alleen de personages zelf uiten hun afkeer, ook de verteller houdt zijn mening niet voor zich. Ik neem Tarbox en zijn inwoners onder de loep door op drie niveaus chronotopen te onderscheiden. Piet Hanema's privé-leven en het bestaan in zijn vriendenkring en generatie worden georganiseerd rond verwante, maar verschillende relaties tussen de ruimten waarin de personages zich begeven, hun temporele oriëntatie en identiteit. Bovendien verschilt telkens het oordeel over het bestaan in Tarbox. Couples is een vorm van suburbiakritiek, maar dan wel een met een genuanceerd, gelaagd karakter.

In Couples ${ }^{159}$ maken we kennis met een groep bevriende middleen upper-middle-class dertigers in het Tarbox van 1963, een kustplaatsje in New England, Massachusetts, een kilometer of veertig buiten Boston. ${ }^{160}$ De meesten hebben goede banen in de stad, sommigen verdienen hun brood in Tarbox zelf. Belangrijker is hoe zij hun vrije tijd invullen: met spelletjes, sport en overspel. Tien echtparen telt de kring, maar stellen zijn er veel meer. Piet Hanema (vierendertig jaar en van Nederlandse komaf) is getrouwd met Angela, maar vormt achtereenvolgens met Georgene Thorne, Foxy Whitman, Bea Guerin en Carol Constantine overspelige paren. Dat Janet Appleby een relatie heeft met Harold little-Smith en zijn vrouw Marcia het aanlegt met Janets man Frank is een publiek geheim. Het levert hun zelfs een nieuwe naam op, Applesmiths, zoals in de Saltines de Saltzes met de Constantines samensmelten. Als later ook Freddy Thorne nog in bed belandt met Piets vrouw Angela, Marcia little-Smith Ken Whitman tracht te verleiden en zelfs Terry Gallagher wordt gesignaleerd met haar muziekleraar, staat vast dat de koppels een losbandig en dynamisch sociaal leven leiden. Voor zolang het duurt. Hoewel ze elkaar vrijer laten dan Harry Angstrom voor mogelijk zou hebben gehouden en hoewel hun escapades plaatshebben tegen de achtergrond van Kennedy's in plaats van Eisenhowers Amerika, krijgen zij het bij vlagen even benauwd als Rabbit. Het hedonisme en de ironie die hun levens de moeite waard maken, vinden in nostalgie, angst, jaloezie, verveling en cynisme steeds geduchter concurrenten.

Met de komst van Foxy en Ken Whitman raakt een fragiel even- 
wicht verstoord. Vertrouwde omgangsvormen raken ontwricht, onderhuidse spanningen komen bovendrijven, nieuwe ontstaan. Als aannemer restaureert Piet hun woning en van het een komt het ander. Piet en Foxy weten hun relatie lang geheim te houden, maar als zij zwanger raakt, weten beiden dat een grens is overschreden. Via tandarts Freddy Thorne regelen zij in het geheim een abortus, maar als een en ander bekend wordt, lopen beide huwelijken op de klippen. Ruim een jaar na Foxy's komst naar Tarbox worden zij en Piet als zondebok uit de kring verstoten. Als nieuw paar zoeken zij elders hun toevlucht. In Tarbox pakken sommigen de draad weer op, maar het leven zal er niet meer hetzelfde zijn.

\subsection{Paradijs, afgrond en weerhaan in het bestaan van Piet Hanema}

In dit Tarbox krijgen Piets gedachten en daden het meeste relief. Zijn bijdragen aan de suburbane uitbreiding van en rond Tarbox, zijn huwelijk met Angela, zijn voortdurende strijd met Freddy en zijn relatie met Foxy zetten de belangrijkste gebeurtenissen in gang. Als geen ander neemt hij deel aan de spelletjes die worden gespeeld. Toch gaat hij daarin niet volledig op. Naast deelnemer is hij een observator die de nodige afstand bewaart. Hij mag dan een centrale figuur zijn, thuis voelt hij zich niet in de kring. Dat komt in zijn ogen onder meer door de subtiele klassenverschillen in Tarbox. 'I've figured out there are two kinds of jerks in this town,' vertelt hij Angela, 'upper-middle-class jerks and lower-middle-class jerks. The upper went to college. My problem is, I'm sort of in the middle' (Updike (1982): p. 405). Deze diagnose sluit aan bij die van de belangrijkste sociologen die zich in de jaren zestig met suburbia bezighouden: Bennett Berger, William Dobriner en Herbert Gans. Bepalend voor leefwijze en identiteit is eerder klasse dan woonplaats. Maar deze sociologische stelling betreft de sociale groep, niet het individu. Als verklaring van Piets problematische bestaan schiet ze tekort. Inzoomen op Piet maakt duidelijk dat een typering als 'buitenwijkbewoner' of 'middle-middle class' niet volstaat. In Couples vormen met name Piets doodsangst, seksuele verlangen en religieuze twijfel een nauwelijks te ontwarren knoop. Omdat deze knoop voor 
een groot deel bepalend is voor Piets stuurloze bestaan, voor de spanningen tussen zijn herinneringen en verwachtingen en daarmee voor de levenswijze in Tarbox' vriendenkring als geheel, zullen we hem eerst onder de loep nemen.

Ten eerste is er de spanning tussen Piets behoefte aan de stabiliteit van zijn huwelijk en gezinsleven en zijn verlangen naar nieuwe ervaringen met minnaressen. Thuis vindt Piet de rust die hij zo nodig heeft. De omsloten tuin van de vrij gelegen achttiende-eeuwse boerderij waarin hij met zijn vrouw en twee kinderen woont, suggereert een hof van Eden. De ambachtelijke, koloniale stijl van het huis, de rechthoekige kamers en lage plafonds geven Piet een beschermd gevoel. Het herinnert hem aan de warmte en geborgenheid in de kas van zijn overleden ouders.

De keerzijde is een gevoel van gevangenschap. Piet houdt van zijn vrouw en dochters, maar 'spaced around him like the stakes of a trap' (ibid: p. 348) doen zij hem verlangen naar avonturen buiten de deur. Wat hem in overspel aantrekt, is 'its adventure, (...) the tension (...), the new landscapes it makes us master' (ibid: p. 429). Zijn verkenning van dat nieuwe landschap levert met Georgene, Bea en Carol weinig problemen op, maar als hij Foxy ontmoet, luidt 'getting out in the world and seeking knowledge' (ibid: p. 343) ook in zijn geval een zondeval in. ${ }^{161}$ Voor Piet is ze een nieuw begin, voorbij de kaders van zijn leven thuis, gesymboliseerd door de rechte witte streep van een overvliegend vliegtuig tijdens hun eerste ontmoeting. In het wit gekleed, kondigt Foxy de lente aan. 'The color white was strange this early in the year, when nothing had budded but the silver maples'(ibid: p. 23). Ook de omgeving rond haar huis ademt uitdrukkelijk de sfeer van nieuw leven. 'More sun by the sea. More life' (ibid: p. 94). De seringen staan er al in bloei: 'wine-colored cones that in weeks would be lavender panicles of bloom' (ibid). Zelfs als elders alles verdroogt, is de kuststrook rond Foxy's huis 'lush and young, green as spring and carved like plush' (ibid: p. 214). Piet weet zich verleid en overtreedt uiteindelijk een van zijn eigen regels, namelijk dat een affaire de huwelijkse orde niet mag verstoren. Hij en Foxy hebben van de verboden vrucht gegeten. 'Patient parents thumbing home seeds in peat had planted a tree whose fruit he had fed to women. The voracious despair of women had swallowed God'(ibid: p. 258). 
Dat de balans tussen geborgenheid en verandering verstoord raakt, is niet alleen het gevolg van Piets verlangen naar nieuwe seksuele ervaringen. Minstens zo belangrijk is zijn angst voor de dood. Sinds zijn ouders zijn omgekomen, speelt de dood een grote rol in Piets bestaan. Regelmatig heeft hij het gevoel elk moment door het ijs te kunnen zakken, in gedachte valt hij in een afgrond en in een droom stort zijn vliegtuig neer. 'At midpoint of his life's arc' (ibid: pp. 272-3) rest hem de weg naar beneden. Terugkijken naar zijn kindertijd heeft geen zin meer, vooruitkijken durft hij niet. Ondertussen verstrijkt de tijd. 'Minutes. Meteors. Bombarding us' (ibid: p. $20)^{162}$

Hoewel Piet in Tarbox een van de weinigen is die nog de kerk bezoekt, biedt zijn geloof hem onvoldoende steun in zijn strijd tegen doodsangst. 'People are the only thing people have left since God packed up,' luidt Freddy's diagnose van seculier Tarbox. 'By people I mean sex' (ibid: p. 145). Ook Piet zoekt in seksuele ervaringen een manier om zijn obsessieve gedachten aan de naderende dood tijdelijk uit zijn hoofd te zetten. 'Nature dangles sex to keep us walking toward the cliff,'(ibid: p. 345) meent hij. Seks houdt hem gaande. Bij minnaressen vindt hij verlichting, al beseft hij dat deze slechts tijdelijk is. Het voldane gevoel is steeds van korte duur, doordat Piet zich telkens weer geïntimideerd voelt door 'the counterthrust of time'(ibid: p. 336). ${ }^{163}$ Piet vreest dat ook zijn affaire met Foxy tekort zal schieten. Symbolisch is het lot van de hamster van zijn dochter Ruth. Het gepiep van het rad waarin het beestje rondloopt, 'eek, ik, eeik, ik', suggereert dat Piet, die het Nederlands machtig is, zich met hem identificeert. Hij voelt zich opgesloten, maar verlaat net als het beestje op een dag zijn kooi, 'discovering (...) undreamed-of continents' (ibid: p. 76). De hamster was al eens eerder ontsnapt, maar deze keer wordt het hem fataal, wat Piet, met het 'eek eeik' nog in zijn hoofd, bijzonder aangrijpt. ${ }^{164}$

Piets behoefte aan geborgenheid en zijn pogingen door overspel zijn doodsangst te lijf te gaan, zijn nauw verbonden met zijn religieuze verlangens en angsten. God speelt in zijn leven een vooraanstaande, zij het problematische rol. Hij gelooft in een strenge, almachtige calvinistische God die over de nietige mens beschikt. Hij verlangt naar een teken dat hem sterkt in zijn overtuiging. Steeds vaker echter, wordt hij tijdens zijn gebeden door twijfel overvallen 
en als hij omhoogkijkt, ziet hij geen door God geschapen orde, maar een donkere, lege nacht vol sterren. 'Amid these impervious shining multitudes he felt a gigantic slipping; sinking upwards, he gripped the dim earth with his eyes' (ibid: p. 272). Hoe langer hoe meer neemt Piet zijn toevlucht tot een aardse bevrediging van zijn verlangens. Hij beseft dat hij hoog spel speelt. Hij brengt zijn gezinsleven in gevaar en gaat bovenal in tegen Gods gebod. Hij bidt om vergiffenis, maar vreest Zijn oordeel. 'God will not be used,' (ibid: p. 257) weet Piet. Angst grijpt hem bij de keel. 'A translucent husk emptied of seed, Piet waited to be shattered'(ibid: p. 259).

Piets vlees is zwak. 's Nachts overdenkt hij zijn zonden, om ze overdag opnieuw te begaan. Foxy raakt zwanger. 'God is not mocked,' (ibid: p. 343) beseft Piet. De zwangerschap is in zijn ogen 'a disaster identical with death' (ibid: p. 345). In meerdere opzichten, zo blijkt. Concreet betekent ze het einde van zijn leven met Angela en zijn vrienden. Ze maakt ook een einde aan zijn leven in zonde, overdrachtelijk beschreven in termen van Piets dood -in een telefooncel is hij een lijk in een aluminium doodskist, zijn kantoor is zijn tombe en volgens Freddy heeft hij zijn eigen graf gegraven (zie ibid: pp. $359,380,416)$. Belangrijker is de verandering van zijn houding ten opzichte van God en de dood. Nadat zijn relatie met Foxy, haar zwangerschap en de abortus bekend zijn geworden, vindt Piet berusting, 'as a dying man after months of ingenious forestallment turns with relief to the hope of an afterlife' (ibid: p. 391). De dood - niet alleen zijn eigen, overdrachtelijke dood, maar ook het overlijden van zijn vriend John Ong - blijkt niet het angstaanjagende lot dat hij zolang heeft gevreesd. In Ongs ogen ziet hij 'plunging, how plausible it was to die, how death, far from invading earth like a meteor, occurs on the same plane as birth and marriage and the arrival of the daily mail' (ibid: p. 428). Na een leven waarin hij gebukt gaat onder de dood, aanvaardt hij een bestaan met de dood, een natuurlijk onderdeel van het leven en een gebeurtenis die hem doet beseffen hoeveel tijd hij nog heeft en hoe vrij hij is deze te gebruiken.

Bovendien wacht hem aan het einde van zijn zondige leven niet Gods wrede oordeel dat hem zolang angst heeft ingeboezemd. Imposant is het wel, 'God's own lightning' die op een mooie zondag in mei tijdens een apocalyptisch onweer Tarbox' kerk in lichterlaaie zet. De zon wordt opgeslokt, als 'spears of fire' geselt de regen de menig- 
te - 'the supernatural proclaimed itself (ibid: p. 439), zoveel is duidelijk. Piet is opgelucht en dankbaar 'for having been shown something beyond him, beyond all blaming' (ibid: p. 443). 'Wash me', staat er al een jaar lang in het vuil op de achterklep van zijn pickup truck. Piet voelt zich door het vele hemelwater gereinigd.

De oude kerktoren kan niet worden gered. In twee opzichten verdwijnt daarmee iets wezenlijks uit het centrum van Piets leven. Als 'pricking steeple and flashing cock' luidt het einde van de toren het einde in van Piets seksuele escapades. De koloniale weerhaan redt het wel. Eeuwenlang heeft hij het centrum van Tarbox gedomineerd. Kinderen groeien op in de veronderstelling dat de oude haan God is: alomtegenwoordig, doordat hij altijd zichtbaar is, en immer eenieder observerend. ${ }^{165}$ Eenmaal op de grond, blijkt de haan echter weinig indrukwekkend. Kinderen staan er in een kringetje omheen en durven hem gewoon aan te raken. Piets dochter Nancy noemt hem zelfs een kip. Voor Piet is de cirkel rond. Ongeveer een jaar na dato staat hij weer op de plek waar hij Foxy voor het eerst ontmoette. Naast de rust van zijn gezinsleven in zijn oude boerderij, het avontuur in Foxy's woning, na zijn doodsangst op het ijs, in de afgrond en het vliegtuig en na zijn verlangen naar een teken van God onder een donkere hemel, is ook de plek waar God een doffe metalen weerhaan blijkt een belangrijke chronotoop in de organisatie van zijn bestaan. Zijn angst voor Gods oordeel blijkt ongegrond. Waar de toren stond, is de lucht nu leeg. Op twee parallelle vliegtuigsporen na, als een seculier symbool voor een nieuwe start. Zij wijzen Piet de weg, in een leven na Tarbox.

\subsection{Verandering zonder vernieuwing in een kring van paren}

Hoewel zowel de kerk - voornamelijk als een sociaal instituut - als overspel bekende thema's zijn in de verbeelding van de suburbane middenklasse, wordt Couples pas een suburbiaroman als we Piet niet alleen begrijpen als een nostalgische zoon, een twijfelachtige echtgenoot, een doodsbange man en een gevallen gelovige, maar evenzeer als de spil in zijn vriendenkring. Piets toeren zetten de toon in Tarbox' kring van paren. 
De stellen vormen een hechte groep. Het leven daarbinnen speelt zich af in een ruimte die op twee manieren is afgegrensd. Ten eerste zijn er de grenzen van Tarbox. Wat zich daarbuiten afspeelt, vindt de groep oninteressant. De meesten hebben buiten Tarbox goedbetaalde banen, maar over geld en werk wordt in deze gemeenschap nauwelijks gesproken - 'one's job was a pact with the meaningless world beyond the ring of couples' (ibid: p. 233). Bovendien zitten de stellen niet te wachten op nieuws van sociaal-politieke aangelegenheden die niet direct op Tarbox betrekking hebben. Afgezien van wat spitsvondigheden tijdens dinner parties tonen zij zich onverschillig ten opzichte van ontwikkelingen in het publieke domein. De paren hebben een privé-wereld ingericht die ze nadrukkelijk afschermen van wat zich erbuiten afspeelt. 'Television (...) implied a universe of profound cold beyond the warm encirclement of Tarbox, friends, and family. (...) Not since Korea had Piet cared about news. News happened to other people' (ibid: p. 214). Illustratief is Freddy's reactie na de moord op Kennedy. Wat hem bezighoudt, is dat zijn feestje misschien niet doorgaat: 'But I've bought all the booze,'(ibid: p. 294) roept hij uit.

Een tweede begrenzing is die van de huizen waarin de stellen hun feestjes geven en het speelveld waarop ze sporten. Spelen is in Tarbox' gemeenschap belangrijk. De stellen beschouwen hun leven zoveel mogelijk als een spel. Het moet leuk zijn en als het niet meer leuk is, speel je een nieuw spel. Sport fungeert als uitlaatklep. Lijnen en spelregels garanderen de paren dat ze op een gecontroleerde manier stoom kunnen afblazen. Belangrijker nog zijn de spelletjes die thuis worden gespeeld. Meer nog dan de plek voor het gezinsleven is het eigen huis de plaats waar huwelijkse saaiheid en spanningen door middel van feestjes, psychologische spelletjes en overspel worden verdreven. Waar de grenzen rond Tarbox beschermen tegen invloeden van buitenaf, garandeert de privé-woning dat frustraties en uitbarstingen binnen de eigen kring binnenskamers blijven.

Binnen deze grenzen ontwikkelt de groep een hedonistische levensstijl die enerzijds is gericht op bewaking van de status-quo, anderzijds op cultivering van onderlinge spanningen om de mallemolen draaiende te houden. Het resultaat is een cyclus van terugkerende evenementen die afwisseling garandeert, terwijl alles bij het oude blijft: 'the round of sports (...) that gave the couples an inex- 
haustible excuse for gathering: a calendrical wheel of unions to anticipate and remember, of excuses for unplanned parties' (ibid: p. 108). Het blijft niet bij die feestjes. Vreemdgaan is voor de paren de manier bij uitstek om in een gesloten circuit op zoek te gaan naar variatie. Voor de bewoners afzonderlijk biedt het de kans om avonturen te beleven in een betrekkelijk veilige wereld. Voor de gemeenschap als geheel maakt het veranderingen mogelijk zonder vernieuwing van buitenaf. ${ }^{166} \mathrm{Na}$ vijf jaar heeft dit een obsessieve dynamick opgeleverd waarin het steeds moeilijker wordt stilstand interessant te houden en waarin steeds extremer gedrag en grotere risico's de status-quo onder druk zetten. De ongeschreven regel dat iedereen het met iedereen mag doen zolang de huwelijken maar niet op het spel komen te staan, blijkt steeds moeilijker te handhaven. Hoe gemakkelijk de balans verstoord raakt, laat onder andere Piets bestaan zien. Wat de groep bijeen moet houden, bedreigt haar tegelijkertijd. ${ }^{167}$

Dit afgegrensde, cyclische bestaan maakt de hechte stellen langzaam maar zeker tot een al te hechte groep. Freddy - met Piet, Foxy en Angela een van de belangrijkste groepsleden - wordt al bang als hij zijn vrienden een weekend niet ziet. 'He thinks we're a circle,' vertelt Angela. 'A magic circle of heads to keep the night out. (...) He thinks we've made a church of each other' (ibid: p. 7). Hun bestaan vertoont inderdaad kenmerken van een rituele orde: strikte regels, een vaste rolverdeling en een herhaling van gebeurtenissen waaraan niemand zich zomaar kan onttrekken. Het donker is zo lange tijd succesvol geweerd, maar hetzelfde geldt voor frisse lucht. "The men had stopped having careers and the women had stopped having babies,' laat de verteller weten. 'Liquor and love were left' (ibid: p. 12). Maar er is een fase aangebroken waarin ook drank en liefde - lees seks - steeds minder kunnen bekoren. In de chronotoop van het cyclische bestaan binnen de eigen kring, in kleine ruimten, is verveling en irritatie gaan overheersen. Angela maakt duidelijk dat ze genoeg heeft van de feestjes waarop Piet flirt met zowat alle vrouwen en Piet zelf krijgt het te midden van steeds weer dezelfde gezichten en lichamen steeds benauwder. Als Bea Guerin hem tijdens een van de feestjes bijvoorbeeld vraagt 'why he didn't want to fuck her', twijfelt Piet - het klinkt als iets in het Nederlands: 'fokker, in de fuik lopen' (ibid). De dampende lijven achtervolgen hem 
tot in zijn bed: 'it's getting too suburban in here,' (ibid) gonst het door zijn hoofd.

\subsection{Een generatie op haar retour}

Een laatste chronotoop krijgt gestalte als we Tarbox' stellen opvatten als een generatie. In een rake schets zet de verteller de wereld neer waarin de stellen opgroeien en waarin ze later als volwassenen hun weg moeten vinden. Door de combinatie van een breed gebaar met welgekozen termen is deze schets tegelijk algemeen en precies, zowel in termen van klasse, economie, binnen- en buitenlandse politiek als cultureel klimaat, 'a culture where adolescent passions and homosexual philosophies were not quite yet triumphant, a climate stil furtively hedonist, (...) a country still too overtly threatened from without to be ruthlessly self-abusive' (ibid: p. 106). Bovendien contrasteert de verteller de opvattingen en levensstijl van Tarbox' paren expliciet met die van hun ouders' generatie. De stellen breken met het milieu waarin ze zijn grootgebracht. Ze rijden niet in dure, zwarte auto's, maar kiezen tweedehands wagens in felle kleuren. Ze sturen hun kinderen niet naar een internaat, maar naar de lokale openbare school. Tegenover formeel gedrag en rigide huwelijken plaatsen zij de vlotte en open relaties in de vriendenkring waarmee we kennismaakten, tegenover plichtsbesef plezier en tegenover een publiek leven het privé-domein - 'one's own home, and then the homes of one's friends' (ibid).

Deze generatic kicst voor een 'fresh way of life' (ibid). Een nieuwe start, in een nieuwe tijd, op een nieuwe plaats. De stellen kiezen bewust voor het afgelegen Tarbox. De verteller voert hun trek naar buiten nadrukkelijk op als een nieuwe fase in de aloude frontier-traditie uit hoofdstuk 2. Tarbox ligt nabij Cape Cod en Plymouth Harbor waar de zeventiende-eeuwse puriteinen een nieuwe wereld wilden stichten. De koloniale weerhaan met een Engelse penny als oog, de centraal gelegen colonial green en de straten die door de puriteinen naar de deugden - 'Divinity, Prudence, Charity and Temperance' - zijn vernoemd, getuigen hiervan. Omschrijvingen van het Tarbox in de jaren zestig van de twintigste eeuw roepen andere motieven uit hoofdstuk 2 in herinnering. De verteller spreekt van 
pastoraal Tarbox, de stellen van een bucolisch paradijs - een 'postpill paradise' (ibid: p. 52) om precies te zijn. ${ }^{168}$

Dat zij aan dit paradijs een moderne invulling geven, zal duidelijk zijn. Tussen de zeventiende-eeuwse saltboxes en verweerde Fedenalist cubes staat de redwood modern-bungalow van de little-Smiths. Spoorlijn en trolley zijn verdrongen door auto's en parkeerterreinen en waar vroeger textiel werd geproduceerd, wordt nu plastic speelgoed gemaakt. Duidelijker nog dan in Couples krijgt Tarbox' contrast tussen traditic en modernisering uitdrukking in Updike's korte verhaal 'The Indian' (1966). Fraaie uitzichten en oude ambachten staan daarin tegenover de verkeersdrukte tijdens de dagelijkse exodus van forenzen uit Boston, de ongerepte kust tegenover vervuiling van de rivier en Tarbox' oude kerk tegenover winkels vol ansichtkaarten, abstracte schilderkunst en boeken van Freud en Camus(zie Updike (1967b): pp. 14-9).

De wijze waarop de paren invulling geven aan het traditionele New England-utopisme levert volgens criticus G.F. Waller een pornotopia op (zie Waller (1972): p. 14). We kunnen Couples inderdaad begrijpen als onderdeel van een traditie waarin suburbia expliciet wordt opgevoerd als een seculier en seksueel Utopia. Tijdens de cocktailparty's van Tom en Betsy Rath wordt nog slechts heimelijk gezoend. In Marilyn French' The Women's Room (1977) flirten Mira Wards vrienden en vriendinnen in het Meyersville van de fifties en sixties al openlijk met elkaar. In het New Canaan van de Hoods in 1973 - in Rick Moody's The Ice Storm (1994) - viert partnerruil hoogtij. Op zogeheten key parties bepaalt de sleutel die gasten uit een schaal vissen met wie ze die avond naar bed gaan. Niet tot ieders genoegen. Zowel in The Women's Room, The Ice Storm als Couples blijken ogenschijnlijk eenvoudige regels gecompliceerder dan gedacht, verveelt plezier verrassend snel en werken open relaties al snel verstikkend. 'This isn't the idyllic retreat you moved to, Marcia,' maakt Piet duidelijk. 'We're sadly suburban'(Updike(1982): p. 309). Wat in het individuele leven geldt, geldt voor deze gemeenschap als geheel: het hoogtepunt is voorbij. Het lijkt maar niet te willen lukken in Tarbox, waarschuwt Roger Guerin Foxy. Het ging bij de puriteinen al mis, vertelt hij. Zij wilden er een haven maken, maar die slibde dicht. 'Like everything in New England, it's passé, only more so' (ibid: p. 31 ). ${ }^{169}$ 
Om dit beeld van een gemeenschap op haar retour scherp te krijgen, is een vergelijking van deze nieuwe generatie met die van haar ouders niet voldoende. We dienen haar te beschouwen in het licht van een nog jongere generatie die op het punt staat Tarbox en omgeving naar haar hand te zetten. In dit verband is Couples te interpreteren als een kleine geschiedenis van suburbanisatie. In Tarbox' omgeving gaat het snel. Gedurende het jaar dat de vertelling bestrijkt, volgen we bijvoorbeeld de werkzaamheden van Piets aannemersbedrijf op Indian Hill. Met ambachtelijkheid heeft de bouw van de moderne ranches niets te maken. Het standaardontwerp komt uit een 'architectuurfabriek' in Chicago - 'canned plans' die geen enkele relatie hebben met de plaats waar ze worden gerealiseerd. Lang niet iedereen kan waardering opbrengen voor deze nieuwste vorm van suburbane woningbouw. Piet klaagt dat de woningen identiek en saai zijn, zijn vriendin Carol vindt ze zelfs afschuwelijk. Zij zijn niet de enigen. De termen waarin de verteller zich uitdrukt, zijn verwant aan die in andere verhalen over de explosieve suburbanisatie in de jaren zestig, bijvoorbeeld Georgia McKinley's 'The Crime' (1965) en Alice Munro's 'The Shining Houses' (1968). In Couples zet de verteller 'the new developments' neer als 'even pastel teeth eating the woods of (...) Indian Hill' (Updike (1982): p. 17). In 'The Crime' 'the hated houses stood line on line across the hills like rows of little white teeth, gnawing off the distance'(McKinley (1992): p. 146). Machines rijten de aarde open, nieuwe wegen laten een grauw litteken achter. En ook in Munro's verhaal staan de nieuwe 'white and shining houses (...) side by side in long rows in the wound of the earth'(Munro (1985): p. 23). De omgeving in deze drie verhalen verschilt - zowel geografisch, sociaaleconomisch als cultureel -, nieuwbouw geldt steeds als bedreiging van het bestaande landschap. Bovendien is suburbanisatie in alle drie onstuitbaar. In Couples weet Piets partner Matt waarom: de tract is big business, op steeds grotere schaal. Steeds minder 'half-ass semicustom type houses' en steeds meer 'prefab units', zoals hij het uitdrukt. De zogeheten war babies worden namelijk volwassen en zij willen een huis in een nieuwbouwproject. In dit verband wordt wel gesproken van een Suburban Generation, een generatie voor wie niet de stad, het platteland of de small town, maar suburbia het referentiekader vormt. Tarbox' paren zijn dan niet een nieuwe generatic 
met nieuwe plannen, maar een gevestigde gemeenschap die zich geconfronteerd ziet met nieuwe ontwikkelingen die ze nog maar zeer ten dele of helemaal niet meer in de hand heeft. Hun tijd is voorbij, suggereert ook criticus Wilfrid Sheed: 'the beautiful surroundings became over-built; the wrong people moved in; America caught up with them'(Sheed (1968): p.1).

Dit proces voltrekt zich ook in Tarbox zelf. Tarbox is niet zoals Indian Hill een nieuwbouwproject. Het is het soort plaats dat in suburban studies bekendstaat als een reluctant suburb of suburb-byinvasion, een oudere gemeenschap die in de loop van een decennium steeds meer suburbanisanten aantrekt, of, omdat het een eind buiten Boston ligt, een cxurb met steeds suburbaner trekjes. Bestaande bebouwing maakt in Tarbox plaats voor nieuwe appartementen en kantoren. Niet alleen verzekeringsmaatschappijen zijn geïnteresseerd, ook de AA wil in Tarbox een vestiging openen. Daarnaast worden, met subsidie van de overheid, bochtige wegen rechtgetrokken, nieuwe scholen gebouwd en snelwegen aangelegd. Ook op sociaal vlak verandert Tarbox snel. Elk jaar, valt Piet op, komen er meer forenzen met jonge gezinnen wonen. In vergaderingen over Tarbox' toekomst nemen steeds vaker 'self-assured young men' het woord en zwijgen de stemmen die in Piet en Angela's tijd dominant waren. Slechts zelden stuiten beslissingen tot modernisering nog op debat. De paren van Piets generatie maken plaats voor een nieuwe lichting suburbanisanten. In Tarbox vormen de Reinhardts samen met een jonge socioloog en een nieuwe dominee 'a distinct social set', met een eigen, van Piets groep afwijkende levensstijl. 


\subsection{Arme Piet}

Suburbaan Tarbox lokt reacties uit die op de drie onderscheiden niveaus nogal verschillen. Allereerst hebben individuele personages elk een eigen visie op hun leven binnen de kring. Meer dan bijvoorbeeld The Man in the Grey Flannel Suit, The Women's Room en The Ice Storm benut Couples de mogelijkheden van de psychologische roman. In innerlijke monologen gaan personages bij zichzelf na hoe $z e$ in het leven staan en hoe ze in de markt liggen. Bovendien houden ze elkaar voortdurend nauwlettend in de gaten, op het obsessieve af. Gedetailleerd bestuderen ze houding en gedrag. Zo bekijken ze niet alleen elkaar, maar vooral ook zichzelf door de ogen van een ander. In dialoog levert dit geraffineerde pogingen op elkaar meningen over zichzelf te ontfutselen, om daarop te kunnen anticiperen, om te kunnen inspelen op verwachtingen of deze juist te beschamen. De vrienden peilen elkaar, plagen, verleiden en schofferen elkaar. Vooral tijdens feestjes en spelletjes dagen ze elkaar uit en cultiveren ze verschil van mening. Maar al te goed beseffen ze dat waar geen spitsvondigheden meer worden uitgewisseld de rit in de mallemolen wel eens dodelijk saai zou kunnen worden. Terwijl de nieuwste lichting suburbanisanten hiervan nadrukkelijk afstand neemt, denkt elk van de sleutelfiguren binnen de kring er het zijne van. Angela heeft nooit gehouden van al deze psychologische spelletjes en trekt zich gaandeweg steeds meer terug. Als nieuwkomer blijft Foxy een buitenstaander, ook al speelt ze, tegen wil en dank, vaak een hoofdrol. Freddy toont zich in zijn rol als spelleider ronduit cynisch en gefrustreerd over het bestaan in Tarbox en Piet weet zijn angsten en twijfels op de valreep om te zetten in ironic.

Deze ironie is Piets belangrijkste wapen in een leven waaraan hij maar geen richting weet te geven. Getoetst aan het ideaal uit hoofd- 
stukken 2 en 3 schiet hij ernstig tekort. Verwarring wint het van visie, twijfel van daadkracht en lange tijd zorgt angst ervoor dat de toekomst weigert te schitteren. Als het erom gaat, weifelt Piet en weigert hij zijn verantwoordelijkheid te nemen. Als er belangrijke beslissingen moeten worden genomen, zijn het anderen - Angela, Freddy en Foxy - die zijn leven een wending geven. ${ }^{170}$ Met hen, en met veel anderen in de kring, onderhoudt Piet een haat-liefdeverhouding. Sommige vrouwen bespotten zijn onhandigheid, maar ondertussen concurreren ze om hem. Freddy haat hem, maar is tegelijkertijd jaloers. En nadat de groep hem jarenlang de hand boven het hoofd heeft gehouden, aarzelt ze niet hem tot zondebok te maken, als zijn fratsen een bedreiging worden. Ze sluit de gelederen en verstoot Piet. Ook de verteller, tot slot, velt geen eenduidig oordeel. Door uit te weiden over Piets onzekerheden, toont hij begrip voor zijn problemen en vraagt hij impliciet om compassie. Door Piets redeneringen echter tot in het absurde door te drijven, maakt bii van de twiifelaar soms een neuroot. Boyendien makat. hii poenlijker, Piets gedragingen belachelijk. De stijl waarin hij een scène neerzet waarin Piet met Foxy dreigt te worden betrapt en hij in nood uit een raam duikt, is zo burlesk, dat van de Piet met wie we elders meeleven nog slechts een stumper overblijft.

\subsection{Mislukt escapisme}

Ten opzichte van de kring als geheel toont de verteller minder mededogen. De stellen zelf zien ook wel in dat de carrousel knarsend tot stilstand is gekomen, maar dat is hem niet voldoende. In tegenstelling tot de verteller in Rabbit, Run neemt hij expliciet afstand van de levenswijze van Tarbox' paren. In zijn ogen heeft hun ideaal misschien kortstondig plezier opgeleverd, maar is het uiteindelijk uitgelopen op een jammerlijke mislukking. In sommige passages verraadt een venijnige omschrijving zijn opvattingen. Aan het strand krijgen de spullen van badgasten bijvoorbeeld het etiket 'hedonistic machinery' (Updike (1982): p. 439) opgeplakt. In andere passages is de verteller langer van stof. Vooral overspel moet het ontgelden. Nadat Foxy's man Ken bijvoorbeeld de verleiding heeft weerstaan om in te gaan op Janet Appleby's avances, acht de verteller het nodig 
om het avontuur van vreemdgaan tegen het licht te houden. 'The first breath of adultery is the freest,' betoogt hij, 'after it, constraints aping marriage develop. Janet and Ken were improved for having stood'(ibid: p. 456). Naast het gedrag van de paren trekt hij ook hun morele standaarden openlijk in twijfel. 'For much of what they took to be morality,' verklaart hij bijvoorbeeld, 'proved to be merely consciousness of the other couples watching them' (ibid: p. 158).

Bovendien plaatst de structuur van de vertelling de levensstijl van de stellen in een kwaad daglicht. Dat zij met hun cyclus van spelletjes in herhaling vallen, blijkt al uit de wijze waarop de verteller 'the round of sports' introduceert: 'touch football, skiing, basketball, sailing, tennis, touch football again' (ibid: p. 108, cursivering $\mathrm{DH}$ ). Hetzelfde gevoel, dat de paren in een cirkeltje ronddraaien, wordt gewekt door de opbouw van de vertelling als geheel. Het eerste hoofdstuk verhaalt van de lente, het laatste heet 'It's Spring Again' (cursivering DH). Het effect is niet een gevoel van geborgenheid in een vriendenkring, maar voorspelbaarheid, verveling en irritatie. Subtieler, maar zeker zo effectief, is de volgorde in de presentatie van de idealen van Tarbox' stellen en hun pogingen deze te realiseren. De verteller formuleert het ideaal - plezier, spontaniteit en intimiteit - pas nadat eerst ruim honderd pagina's lang uit de doeken is gedaan hoe zwaar de last van overmatige onderlinge bemoeienis weegt en hoe hoog sociale spanningen zijn opgelopen. We kunnen moeilijk anders dan de nieuwe start - 'a fresh way of life' in pastoraal Tarbox - met de nodige scepsis bezien.

Het hedonisme van de stellen wordt opgevoerd als een mislukt escapisme. In dit opzicht vertoont Couples overeenkomsten met een aantal invloedrijke cultuurkritische teksten dat in de loop van de jaren zeventig verschijnt, met name Richard Sennetts The Uses of Disorder (1970) en The Fall of Public Man (1977) en Christopher Lasch' The Culture of Narcissism (1978). Lasch schetst een somber, bij vlagen cynisch psychologisch portret van een ontspoorde Amerikaanse samenleving. Hij voert the narcissist op, die - ook bij Lasch weer in tegenstelling tot de rugged individualist - voor zijn gevoel van eigenwaarde afhankelijk is van de voortdurende aandacht van anderen. Zonder hun bewondering kan hij niet, zoals ook Tarbox' stellen in elkaars ogen zichzelf zoeken. ${ }^{171}$ Lasch richt zijn pijlen vooral op de ontwikkeling van een 'ethic of leisure, hedonism, and self-fulfill- 
ment' (Lasch (1979): p. 374). Hij spreekt van een psychological man die voortdurend op zoek is naar bevrediging van zijn eigen verlangens, maar telkens slechts kortstondig voldaan is. Een wanhopig streven naar onmiddellijke bevrediging, luidt de diagnose, heeft een permanente staat van rusteloosheid tot gevolg. De narcist gaat gebukt onder 'anxiety, depression, vague discontents' en 'a sense of inner emptiness' (ibid: p. 42). In Lasch' termen kunnen we Tarbox' obsessieve dynamiek opvatten als een fraai voorbeeld van een te ver doorgevoerd hedonisme. De stellen lijken bevrijd, maar krijgen het met de dag benauwder. Hun cyclus van spelletjes en overspel is te karakteriseren als een 'pseudoprogressive society on behalf of the status quo'(ibid: p. 24). En in Lasch' formulering 'the pursuit of happiness to the dead end' (p. 21) vinden we niet alleen Tarbox' even eindeloze als vruchteloze streven terug, maar ook de hoge prijs die met name Piet en Foxy daarvoor betalen: de dood van hun ongeboren kindje.

Net als Lasch signaleert ook Sennett problemen in de onderlinge relaties binnen de eigen, beperkte kring. Hij betreurt vooral de ontstane cultus van intimiteit. Waar Lasch vrij algemeen spreekt van 'the final product of bourgeois liberalism' (ibid: p. 22), kritiseert Sennett specifiek de inwoners van suburbia. Hij beschouwt suburbanisatie als de uitkomst van een verlangen naar zuiver wonen. Zuiver, omdat in de buitenwijk slechts wordt gewoond en bijvoorbeeld niet gewerkt, en bovendien omdat men zich ontdoet van 'de ander' om te kunnen leven tussen gelijkgezinden. Sennett spreekt van een dwangmatige hang naar gemeenschap, een gemeenschap die zich afgrenst van de buitenwereld en zich sociaal en emotioneel terugtrekt uit de omringende omgeving. We kunnen Tarbox' paren als zodanig opvatten. Ze zoeken bewust zowel fysieke als sociale afzondering, mengen zich niet in publieke aangelegenheden en hebben bovenal een extreme behoefte aan onderlinge intimiteit. Freddy's 'magic circle of heads to keep the night out' houdt in Sennetts terminologie een 'community against the world' in, de relatie met de buitenwereld kan worden uitgedrukt met een slogan als 'we won't get involved'(Sennett(1993): Pp. 296,310). ${ }^{172}$

Bovendien is er in beide suburbiaportretten sprake van een parallel met volwassenwording. Als de adolescent zijn eerste zelfstandige stappen zet in een nieuwe wereld, betoogt Sennett, ontbreekt het hem aan de ervaring waarover een volwassene beschikt. Dit levert 
onzekerheid op. Deze kan de adolescent reduceren door te proberen overzicht te krijgen, greep te krijgen op het geheel. Mogelijk resulteert dit in eliminatie van wat onbekend is, zoals de suburbane gemeenschap buitensluit wat anders is (zie Sennett (1996): pp. 12-21, 36). Freddy's obsessieve angst voor het uiteenvallen van de vriendenkring is op te vatten als een verlangen naar een overzichtelijke gemeenschap van een beperkt aantal stellen. Overzichtelijk zowel in ruimtelijke zin - alles speelt zich af binnen Tarbox' grenzen, liefst zelfs binnenskamers - als in de tijd: veranderingen in de samenstelling van de groep of in de onderlinge verhoudingen zijn onwenselijk, omdat ze in de bestaande, bekende situatie onzekerheid introduceren. ${ }^{173}$ In Tarbox betekent het bovendien dat het spelkarakter van de gevestigde orde overeind moet blijven. Zoals een kind in zijn spel een eigen, overzichtelijke wereld inricht, zo houden de paren de omringende werkelijkheid buiten de deur zolang ze opgaan in hun spel. In die zin kunnen we hen onvolwassen noemen. Illustratief is wat de verteller de 'chronic sadness of late Sunday afternoon' noemt:

when the couples had exhausted their game, (...), and saw an evening weighing upon them, an evening without a game, (...) an evening when marriages closed in upon themselves like flowers from which the sun is withdrawn, an evening giving like a smeared window on Monday and the long week when they must perform again their impersonations of working men, (...) of mothers and housekeepers, of adults who are not the world's guests but its hosts (Updike (1982): pp. 73-4).

Meer dan in de expliciete kritiek van de verteller ligt de kwaliteit van een roman als Couples in passages als deze. Daarin belichaamt één bepaalde gemeenschap een cultuurkritiek verwant aan die van Lasch en Sennett. Verschillende registers worden bespeeld, niet in een letterlijk commentaar, maar in een beeldspraak waarin zowel maatschappij- en cultuurkritische argumenten doorklinken als de frustraties, angsten en verwachtingen uit een gedetailleerd portret. Couples verbeeldt een suburb als een in zichzelf gekeerde gemeenschap die haar mogelijkheden heeft uitgeput. Het stelt niet alleen een diagnose, maar maakt bovendien duidelijk wat het voor deze 
stellen betekent te lijden aan het bestaan in Tarbox. Gaat het om de kring van paren, dan komt Couples' kritiek in het licht van de bovenstaande passage tot uitdrukking in een metafoor: het weekend is voorbij. Het wordt donker en bij hen die doordeweeks niet functioneren, staat maandag voor de deur.

\subsection{Vreemd, maar o zo vertrouwd}

Beschouwen we, tot slot, de kring van paren als een generatie, dan luidt het oordeel niet zozeer dat een ideaal is verkwanseld, als wel dat het door de tijd is ingehaald. Net als in Rabbit, Run krijgt in Couples met het portret van een bepaald milieu op een bepaalde plek een beeld gestalte van een samenleving en cultuur in een bepaalde periode. Om de gemeenschap van paren neer te zetten als een specifieke generatie voorziet de verteller haar van een historische sociaal-economische, culturele en politieke context. Op de achtergrond heerst een voortdurende dreiging. Dat het klimaat van slag lijkt -er heerst droogte, ijskappen smelten, bossen verdwijnen - is naast een natuurverschijnsel vooral ook een symbool voor ingrijpende ontwikkelingen op ander terrein. Omineus is ook de zonsverduistering die zomer. Er zijn spanningen in een tijd van Koude Oorlog, de situatie in Vietnam dreigt uit de hand te lopen, er heerst onrust op de financiële markten en Kennedy wordt vermoord. Op deze dynamiek biedt het hedonisme en escapisme van de stellen - in Lasch' en Sennetts optiek een 'retreat from politics' - duidelijk geen afdoende antwoord. Het is niet zo verwonderlijk dat hun rol, zelfs binnen Tarbox' lokale politiek, met de komst van een nieuwe generatie 'self-assured young men' snel is uitgespeeld.

Zo beschouwd, is de trek van de stellen naar het afgelegen Tarbox niet zozeer een vlucht naar, als wel een vlucht van. In 'Son of the Group' (1982) interpreteert Michael Novak het suburbane bestaan van de paren uitdrukkelijk als een keuze voor afstand en afscherming. 'The reason for suburban life,' stelt hij, 'is isolation from the poverty, misery, and noisomeness of the human race; its aim is security, placidity, likemindedness' (Novak (1982): p. 60). In deze lezing krijgen de stellen trekken van de zich afzonderende upper-middle class waarmee ik het vorige hoofdstuk besloot. Hun cyclus van ver- 
andering zonder vernieuwing kan worden opgevat als een voorbode van de negatieve politiek die in de jaren tachtig en negentig wordt beschouwd als krampachtige behoudzucht. Vooruitzien is in dat geval primair angst voor verval, een perspectief in schril contrast met het geloof in vooruitgang dat de nieuwe generatie suburbanisanten in Tarbox uitstraalt. Tegen haar, vooral tegen de daadkracht die zij aan de dag legt, legt de oude vriendenkring het af, is ook Novaks conclusie. Uiteindelijk, schrijft hij treffend, 'the mobility of the monstrous, growing American way of life shoves the couples aside like trees in front of a bulldozer' (ibid: p. 61).

Dat de tijd van de stellen voorbij is, betekent geenszins dat we hun levensstijl eenvoudig kunnen afdoen als een tijdelijke aberratie in een ver verleden. Integendeel. In Couples wordt de historische context op subtiele wijze opgerekt. De verteller speelt hierbij een belangrijke rol. In retrospectief verhaalt hij van het leven van de stellen in de eerste helft van de jaren zestig. Hun wereldje is duidelijk niet het zijne. Hij maakt daarvan geen deel uit. Dat geldt niet voor de samenleving waarin zij dat wereldje overeind trachten te houden. Nadat de verteller ruim honderdvijftig bladzijden in de derde persoon over Tarbox' paren heeft verteld, schakelt hij middenin een passage over de little-Smiths en Appleby's over op de eerste persoon. 'Meanwhile,'valt plotseling te lezen, 'our advisory capacity in Vietnam was beginning to stink' (Updike (1982): p. 158, cursivering DH). De wereld van de stellen blijkt tevens die van de verteller. Daarin betrekt hij met deze verandering in verteltechniek bovendien de lezer. Hoewel het 'onze' ongetwijfeld sterker appelleert aan de contemporaine Amerikaanse lezer dan aan latere lezers of lezers buiten de Verenigde Staten, maakt het ook deze laatsten alert. Wordt ook op ons een beroep gedaan, vragen zij zich mogelijk af. Ook al vinden we Tarbox' gemeenschap misschien letterlijk en figuurlijk een vreemde wereld, wat er met Amerika in Vietnam is gebeurd, weten we. Dat maakt niet alleen deel uit van de wereld van de stellen en de verteller, maar evengoed van die van ons. Een grens wordt overschreden. Hoe vreemd is Tarbox eigenlijk? Kunnen we de gemeenschap van de stellen afdoen als een wereldje waarmee we niets te maken hebben? We kunnen het beschouwen als een object van hilariteit en kritiek en daarmee afstand houden, maar is daarmee de kous af? Het is wellicht zinvol bij onszelf te rade te gaan. Hoe ver- 
houden wij ons tot deze uitkomst van vooruitgang, welvaart en bevrijding, vraagt Joyce Flint zich bijvoorbeeld af in een analyse van Couples' portret van de paren. 'If we experience a vague sense of horror at their predicament,'oppert ze, 'it might be that we know them toowell'(Flint(1968): p. 347).

Dat Couples impliciet dit soort vragen oproept, is het resultaat van nog een tweede verandering in de vertelwijze. In zijn samenvatting van hoe het de paren vergaat na Piet en Foxy's verstoting, wisselt de verteller de tot op dat moment gebruikte verleden tijd in voor de voltooid tegenwoordige en tegenwoordige tijd. De Jazinski's 'have moved', de plaatselijke huisarts heeft het een en ander geleerd over de nieuwste voorbehoedmiddelen en in Tarbox gaat het gerucht dat de kerk niet zal worden gerestaureerd. 'Now,' leidt de verteller even verderop Couples uit, 'though it has not been many years, the town scarcely remembers Piet' (Updike (1982): p. 458). De suggestie is dat het leven in Tarbox niet met dit verhaal ten einde loopt. 'Angela is still around', Piet en Foxy 'live in Lexington, where, gradually, among people like themselves, they have been accepted, as another couple' (ibid). Ze maken deel uit van een werkelijkheid buiten de grenzen van het verhaal over Tarbox. Ze zijn in Lexington geaccepteerd, vallen er als een van de vele stellen nauwelijks op. Voor hen geldt, wat geldt voor Harry Angstrom in Rabbit, Run. Ze halen dingen uit die ons amuseren, waarover we ons verbazen en waaraan we ons ergeren, maar met hun middenklasselevens zijn velen van ons o zo vertrouwd. 


\section{Conclusie}

In 1968 stelt Michael Novak verbijsterd vast hoe zelden onze levens in de literatuur worden verbeeld. Hij doelt op een middenklassebestaan vol supermarkten, parkeerplaatsen en feestjes in de buurt. Personages zijn zo vaak ontdekkingsreizigers, soldaten, wanhopige nihilisten, detectives of Hollywoodhelden, 'that we begin to think novelists dwell in underworlds as unlike as possible our suburban habitats' (Novak (1982): p. 59). Updike, vervolgt hij, 'has refused to be intimidated into escaping to other hells than ours. His critics wish him to dare bolder things (...) and head for elsewhere; to write us significant lessons. A writer, one is led to suppose, cannot be middle class' (ibid). ${ }^{174}$ In Rabbit, Run en Couples krijgen in twee buitenwijken wellicht weinig spectaculaire, maar desalniettemin intrigerende dagelijkse levens gestalte. Ik heb de aandacht gevestigd op hoe in en rond bepaalde ruimten identiteit en temporele oriëntatie uitdrukking krijgen. Deze chronotopische lezing maakt duidelijk dat de kritiek in beide romans grote overeenkomsten vertoont met die in belangrijke sociaal-en geesteswetenschappelijke betogen en literaire verhalen uit hoofdstuk 3 en brengt bovendien aan het licht hoe deze daarvan verschilt.

In een verhaal georganiseerd rond een te klein appartement, doodlopende wegen, een eng sociaal circuit en een laatste, wanhopige spurt in het niets maken we kennis met Harry Angstrom. Net als veel andere fictionele buitenwijkbewoners zoekt hij een eigen manier om te ontsnappen uit het web van verwachtingen en eisen waarin hij is verstrikt. Verlamd door nostalgie en bij gebrek aan toekomstvisie gaat hij echter stuurloos door het leven. Hij durft geen beslissingen te nemen en het ontbreekt hem aan de nodige daadkracht. In Rabbits Mt. Judge gaan idealen verloren en worden verwachtingen beschaamd. Waar Mills, Whyte, Riesman en Lee een dergelijk bestaan expliciet kritiseren in het licht van uitgesproken 
idealen, slaagt Harry er maar niet in te reflecteren. De beklemming in Rabbit, Run is zo acuut dat hij geen mogelijkheid ziet afstand te nemen. Hoewel we zo nu en dan met andere personages en de verteller meekijken en -denken, is Rabbits beperkte blik en oordeelsvermogen onze belangrijkste ingang in zijn benauwde bestaan. Veel van zijn gedachten en daden zijn ronduit egoïstisch, maar ook al kunnen we ze niet waarderen, we worden wel verleid tot begrip voor zijn twijfel en onzekerheid. Rabbit, Run is te lezen als een impliciete kritiek op het suburbane lower-middle-class bestaan in Mt. Judge, maar in tegenstelling tot bijvoorbeeld Keats' The Crack in the Picture Window en Yates' Revolutionary Road voert niet cynisme of sarcasme, maar compassie de boventoon.

In Couples heb ik chronotopen onderscheiden op drie niveaus. Op elk ervan krijgt het bestaan in middle- en upper-middle-class Tarbox een ander aanzien en verschilt het oordeel daarover. Piet Hanema's leven is georganiseerd rond zijn eigen oude boerderij en de groene, bloeiende omgeving rond Foxy's huis, krakend ijs en neerstortende vliegtuigen en een alomtegenwoordige weerhaan die eenmaal op de grond slechts een eenvoudige metalen vogel blijkt. In deze omgeving leren we Piet kennen als iemand die niet kan kiezen tussen avontuurtjes en huwelijkse rust, die doodsangsten uitstaat en tegelijkertijd het teken van God waarnaar hij zo verlangt met angst en beven afwacht. Net als Rabbit schiet Piet in het licht van de idealen uit hoofdstukken 2 en 3 tekort. Hij is verward, op belangrijke momenten legt hij zijn lot in handen van anderen en hij schuift de verantwoordelijkheid voor zijn daden af.

In de kring van paren staan afgegrensde ruimten centraal - Tarbox op afstand van de buitenwereld, sportvelden om gereguleerd stoom af te blazen en woningen om elkaar tijdens feestjes en psychologische spelletjes te verleiden en uit te dagen. Binnen deze grenzen zijn de stellen op zoek naar variatie zonder de status-quo in gevaar te brengen. Resultaat is een hedonistische cyclus die na plezier en genot vooral verveling en ergernis is gaan wekken. Binnen een al te hechte suburbane gemeenschap blijkt een bevrijd bestaan steeds benauwder geworden.

Beschouwen we deze kring als generatie, dan valt allereerst op hoezeer het portret leunt op een aantal bekende motieven uit hoofdstuk 2 - pastoraal en paradijselijk Tarbox als bestemming van 
de traditionele trek naar buiten. Ten opzichte van hun ouders vormen de stellen er een nieuwe generatie met nieuwe idealen. In het licht echter van de jongste lichting suburbanisanten is hun tijd voorbij. Waar de nieuwkomers Tarbox in hoog tempo moderniseren, doen de paren er tijdens vergaderingen het zwijgen toe.

Tarbox' bewoners beoordelen hun bestaan elk op hun eigen manier. Uit innerlijke monologen, uit wat ze doen en laten, uit dialogen en terzijdes van de verteller blijkt zowel afstand, ironie als cynisme. Sleutelfiguur Piet wekt beurtelings medelijden en afkeer, werkt nu eens op de lachspieren en doet dan weer een beroep op ons geweten. Expliciete kritiek is er op de levensstijl in de kring als geheel. Zowel uit het commentaar van de verteller als de vertelstructuur spreekt een veroordeling van het hedonisme als een mislukte vorm van escapisme. Deze is sterk verwant aan Lasch' en Sennetts cultuurkritieken, waarin met name de obsessieve behoefte aan onderlinge aandacht en intimiteit en het daarmee gepaard gaande gebrek aan betrokkenheid bij de buitenwereld het moeten ontgelden. Zich terugtrekken blijkt geen afdoende antwoord op de dynamiek die deze behoudende gemeenschap omringt. Een tijdje heeft ze een reluctant suburb naar haar hand weten te zetten, maar zo gauw prefab ranches als paddestoelen uit de grond beginnen te schieten, is haar rol uitgespeeld.

Deze drie in analyse en interpretatie onderscheiden lagen zijn in Updike's roman hecht verweven. Achtergrondschetsen lopen over in de beleving van bewoners, het commentaar van de verteller borduurt voort op het gevoel van onbehagen in de kring, beeldspraak en symboliek gaan hand in hand met ordinaire klachten. Op de lezer wordt een complex beroep gedaan. We worden uitgenodigd afstand te nemen $e n$ ons te identificeren. Couples overtuigt en verleidt. Zoals sociaal- en cultuurkritische betogen à la Riesman en Sennett, nodigt het uit tot instemming of verweer, maar dat niet alleen. Het wekt een gevoel van afkeer op en vraagt tegelijkertijd impliciet begrip op te brengen. Bovendien houdt het de lezer een spiegel voor. Waar veel suburbiakritiek afstand neemt van de buitenwijk en haar bewoners, overschrijdt Couples grenzen - tussen personages en verteller en tussen hun wereld en de onze. Suburbia moet er dan misschien aan geloven, maar ook de lezer blijft niet buiten schot. 
In het vorige hoofdstuk werd het middenklassesuburbia uit een aantal belangrijke kriticken geconfronteerd met concurrerende versies van de buitenwijk en haar bewoners. Dit hoofdstuk liet zien dat suburbiakritiek heel verschillende vormen kan aannemen. Van een eenduidige antisuburbane mythe is geen sprake. Twee romans stonden centraal. Deze leggen verbanden met uiteenlopende teksten en dragen aan de beeldvorming van suburbia subtiele variaties bij, maar genregrenzen worden gerespecteerd. Het volgende hoofdstuk gaat over Douglas Couplands Generation X (1991). Ook dit boek is een roman, maar dan wel een waarin vreemde elementen zijn binnengeslopen. 

Woestijnzand in de vooruitgangsmachine Verhalen uit de periferie in Couplands

\author{
Generation X
}





\section{Inleiding}

In Generation X: Tales for an Accelerated Culture (1991), de debuutroman van de Canadese schrijver Douglas Coupland, hebben verteller en hoofdpersonage Andy Palmer en zijn vrienden Dagmar Bellinghausen en Claire Baxter zich begin jaren negentig teruggetrokken in Palm Springs, aan de rand van de Mojave woestijn in Californiě. De eindtwintigers wonen er in gehuurde bungalows en voorzien met eenvoudige baantjes in hun levensonderhoud. Andy en Dag werken in een bar, Claire in een kledingzaak. Daaraan beleven ze weinig genoegen, maar het levert genoeg geld op om hun leven op de vlucht nog even te kunnen rekken. Uit onvrede hebben ze alledrie, letterlijk en figuurlijk, afstand genomen van hun levens tot dan toe, respectievelijk in Portland, Oregon, Toronto, Canada en Brentwood, een buitenwijk van Los Angeles (die in hoofdstuk 6 centraal staat). Andy en zijn vrienden hebben de periferie opgezocht om tot rust te komen. Ze nemen daarvoor de tijd. Ze halen herinneringen op, spuien hun onvrede over de samenleving en cultuur waarin ze het spoor bijster zijn, maken uitstapjes, ontvangen vrienden en vertellen elkaar bovenal verhaaltjes. Duidelijk is dat hun verblijf in de woestijn slechts tijdelijk is, onduidelijk waar ze hierna naartoe kunnen. Op een dag blijken Dag en Claire plotseling naar Mexico vertrokken. Andy heeft geen idee wat hij daar zou kunnen gaan doen, maar zijn vrienden hebben zijn honden meegenomen, dus volgt hij hen. Hoe het de drie op hun nieuwe stek vergaat, krijgen we niet te lezen. We verlaten Andy als hij op het punt staat de grens te passeren.

In de eerste helft van de jaren negentig ontketent Couplands debuutroman een ware hype. In veruit de meeste gevallen wordt gesproken over een generatie X die met Andy, Dag en Claire's levensstijl en opvattingen weinig tot niets te maken heeft. ${ }^{175}$ In dit hoofdstuk staat niet de hype, maar de roman centraal. Waarvoor 
zijn Andy en zijn vrienden op de vlucht? Heeft hun zoektocht een doel? Duidelijk is dat er in de loop van de jaren zeventig en tachtig ten opzichte van Rabbits Mt. Judge en Couples' Tarbox veel is veranderd. De vraag is hoe de generatie X zich tracht staande te houden en, bovenal, in welke zin Couplands portret van deze generatie een bijdrage is aan de verbeelding van wat we in termen van hoofdstuk 3 een laat-of postsuburbane middenklasse kunnen noemen. 


\section{Drie bronnen, één versie van de wereld}

Voor een cerste indruk van de redenen voor de vlucht naar Palm Springs kunnen we afgaan op Andy's verslag van hoe hij en zijn vrienden er zijn terechtgekomen. Dag heeft gebroken met zijn leven als marketingmedewerker. Hij wordt ziek van het kantoor waar hij werkt en het gebrek aan carrièreperspectief in zijn functie deprimeert hem. Hij gooit het roer radical om. Hij besluit nooit meer een voet in een kantoor te zetten, huurt een kelderappartement omdat de lucht bovengronds te middle class is, begint drugs te nemen, stort in en komt uiteindelijk in Palm Springs terecht. Claire arriveert op de dag waarop volgens Nostradamus' voorspellingen de wereld vergaat. Uit angst ontvlucht haar vader met zijn vierde vrouw en kinderen L.A.. De Baxters zijn rijk en pretentieus, maar doordat ze onderling weinig met elkaar ophebben, willen ze als gezin maar niet functioneren. Vader heeft slechts oog voor zijn zakenvrienden, zijn vrouw zit zich stierlijk te vervelen en de kinderen doden hun tijd met oeverloze blabla. Als zij uit Palm Springs vertrekken, besluit Claire te blijven. Over zichzelf vertelt Andy dat hij eind jaren zeventig een totale zonsverduistering aanschouwde. Hem bekroop 'a mood of darkness and inevitability and fascination' (Coupland (1995a): p. 3), een gevoel dat jongeren volgens hem sinds het begin der tijden moeten hebben gehad als zij naar de hemel keken 'and watched their sky go out' (ibid: p. 4). Die dag is het donker geworden, nu zit Andy in de woestijn op zonsopgang te wachten.

Andy vertelt ons over wat hem en zijn vrienden beweegt en wat hen tijdelijk tot stilstand heeft gebracht. Hij schetst achtergronden, haalt herinneringen op, doet verslag van hun activiteiten in Palm Springs en reflecteert daarop. Vaak gaat zijn aandacht uit naar alledaagse bezigheden, kleine tragikomische gebeurtenissen en op het eerste gezicht onbeduidende dingen om hen heen. Met oog voor 
detail en gevoel voor subtiele signalen schetst hij een portret van de samenleving en cultuur waaruit ze zijn weggelopen en waarin zeop de een of andere manier zullen moeten terugkeren. Speciale aandacht besteedt Andy aan de verhalen die hij en zijn vrienden elkaar vertellen. Soms geven ze daarin uitdrukking aan hun onvrede met hun vorige levens, soms vertellen ze over hun diepste verlangens en toekomstdromen. Vaak gaat het om zelfverzonnen verhaaltjes die we kunnen typeren als moderne allegorieën en sprookjes - tales als tegenhanger van de accelerated culture van de Amerikaanse westkust.

Naast Andy's vertelling beschikken we in Generation X over nog twee bronnen. Deze bieden informatie in een vorm die we doorgaans niet in een roman tegenkomen. Achterin het boek vinden we onder het kopje 'Numbers' een reeks cijfers en percentages die zijn ontleend aan studies van uiteenlopende instituten en die zijn verschenen in diverse tijdschriften en rapporten. Deze statistieken voorzien Andy's vertelling van een kwantitatieve back-up. Ontwikkelingen in Amerika tussen 1947 en 1991 die de drie bezighouden, worden als getallen gepresenteerd: de groeiende invloed van commercie en media, milieuvervuiling, toenemende armoede en dalend huizenbezit onder jongeren, de daling van het aantal huwelijken, afkalvende sociale zekerheid, slechte carrièreperspectieven en de daaraan verwante afgenomen kans te stijgen op de sociaal-economische ladder.

De tweede bron die niet tot Andy's vertelling behoort, is een populair-sociologisch lexicon met begrippen, kreten, neologismen, oneliners en cartoons die de samenleving typeren waarin de dric zich menen te bevinden en uitdrukking geven aan belangrijke reacties daarop. Afgedrukt in de marge rondom Andy's verhaal vormen ze samen met de vaak aforistische hoofdstuktitels letterlijk een kader waarin de hoofdvertelling kan worden begrepen. Soms verhelderend, soms vaag, soms verklarend, soms kritisch, vormt het daarop een toelichting of levert het daarop commentaar. Belangrijke begrippen die Andy's introductie van de drie omlijsten, zijn onder meer de poverty jet set waarvan de drie deel uitmaken - een groep die 'chronisch' op reis is, wat ten koste gaat van een vaste baan en carrière, een vaste woonplaats en langdurige relaties -, ozmosis dat aangeeft dat Dags vorige baan niet beantwoordt aan zijn zelfbeeld, brazilification dat doelt op de groeiende kloof tussen arm en 
rijk en de daarmee gepaard gaande verdwijning van de middenklasse, en overboarding: 'overcompensating for fears about the future by plunging headlong into a job or life-style seemingly unrelated to one's previous life interests' (zie ibid: pp. 6, 11, 25, 26). Met hoofdstuktitels als 'The Sun is Your Enemy', 'Our Parents Had More', 'I Am Not a Target Market,' 'It Can't Last' en 'Dead at 30, Buried at 70' vormen deze termen het kader waarbinnen Andy, Dag en Claire zich trachten te bewegen.

Elk van de drie bronnen heeft zijn beperkingen. Het grootste deel van de tijd vertelt Andy niet achteraf over hun bezigheden in Palm Springs, maar doet hij verslag terwijl activiteiten plaatshebben. In dit live verslag ontbreekt het hem aan de tijd die nodig is om zaken rustig een plaats te geven. Bovendien heeft hij als ikverteller toch al een beperkt overzicht. Andy lijkt zich hiervan bewust en stelt zich bescheiden op. Hij laat de anderen in hun eigen woorden hun verhaaltjes vertellen en als hij bijvoorbeeld Dags achtergrond schetst, geeft hij duidelijk aan dat hoewel hij zich zoveel mogelijk op diens woorden baseert, het niettemin zijn reconstructie betreft. Weidt Andy over zichzelf uit, dan blijkt hij een individu in verwarring. Hij is te onzeker om zichzelf bloot te geven en wekt de indruk evenveel achter te houden als te onthullen. Hij is nog druk bezig verschillende episoden uit zijn leven hun juiste plaats te geven en moet daarom volstaan met fragmenten. Een afgerond verhaal kunnen we van hem niet verwachten.

Het margelexicon bevat naast begrippen die het een en ander verhelderen veel obscure kreten en oneliners. Wat te denken van stop history, control is not control of you are not your ego (ibid: pp. 40, 116, 156)? Daarnaast zijn er termen die gemakkelijker zijn te begrijpen, maar waarvan zeker niet meteen duidelijk is wat ze zeggen over de wereld van de drie, bijvoorbeeld eroticize intelligence, the love of meat prevents any real change en reinvent the middle class (ibid: pp. 10, 81,112). De cijfers op het eind, tot slot, presenteren uiteenlopende ontwikkelingen. Maar waarom zijn deze cijfers afgedrukt en andere weggelaten? Dat het een selectieve reeks gegevens betreft, is duidelijk, maar wat is het selectiecriterium geweest? Bovendien mogen de statistieken misschien objectiviteit suggereren, ze spreken geenszins voor zich. Dat het aantal huizenbezitters onder jongeren bijvoorbeeld tussen 1973 en 1987 is afgenomen, kunnen we eenvoudig afle- 
zen, wat dat kan betekenen niet. En wat betekent het dat 44 procent van de ondervraagde jongeren zich een huwelijk wenst zoals dat van zijn ouders en 56 procent niet?

Dat uit deze drie bronnen toch een betekenisvol, coherent beeld valt af te leiden, heeft te maken met hun onderlinge relatie. Hoewel er veel ruimte overblijft voor interpretatie, wordt in veel gevallen wat in de ene bron onduidelijk is in de andere opgehelderd. En informatie die in de ene bron ontbreekt, wordt vaak in de andere aangevuld. Het margelexicon en de cijfers vullen Andy's vertelling aan, Andy's vertelling en de cijfers helpen zelfs de duisterste kreten in de marge te begrijpen en Andy's vertelling en het lexicon, op hun beurt, helpen ons de cijfers op het eind te duiden. Deze driehoeksverhouding is een belangrijk kenmerk van het beeld van de samenleving en cultuur waarin Andy, Dag en Claire zich een houding proberen aan te meten. Hoofdvertelling, margetekst en statistieken grijpen in elkaar, zijn begrijpelijk in elkaars termen. In Generation X kriiot zo een gesloten wereldheeld gestalte ne masterhapnnii die wordt opgevoerd, is de maatschappij zoals ze door Andy, Dag en Claire wordt begrepen. Wat tot stand komt, is hun versie van de wereld. Begrip van die wereld is nodig om inzicht te krijgen in de desoriëntatie van de drie en in de wijze waarop ze daarmee trachten om te gaan. 


\section{Vier ontwikkelingen in context}

In de wereld van de drie overheersen vier ontwikkelingen. Deze zijn in de loop van de jaren zeventig en tachtig in uiteenlopende teksten an de orde gesteld, wat de vraag oproept hoe origineel Generation $X$ is.

\subsection{Consumentisme, milieudegradatie en horizonvervuiling}

Andy, Dag en Claire staan voor een generatie voor wie de consumptie van de juiste producten en het dragen van de juiste mode op het juiste moment belangrijk is. Bedreven lezen ze hun materiële omgeving. In een oogopslag wordt merk, stijl en type bepaald en volgt een verhaal over de levensstijl van de eigenaar. Desalniettemin houdt vooral de keerzijde van de consumptiemaatschappij hen bezig. Ze maken zich zorgen om de vervuiling van milieu, woon-en werkomgeving. Dag vertelt bijvoorbeeld over de circulerende giffen en virussen in het sick building waarin hij werkzaam was en over het loden schort waarmee een collega zich beschermde tegen de straling van de computermonitor. In Palm Springs schatten de drie graag hoe lang het gebruiksvoorwerpen kost om te vergaan - dumpster clocking noemen ze dat. Skischoenen spannen de kroon, zij overleven zelfs de zon. Illustratief is daarnaast een verhaal van Dag over twee vrienden op weg naar een supermarkt. De één is woedend over de vervuiling door alomtegenwoordige commercie en uit de hand gelopen consumptie. Dieren leggen het loodje en toeristen hebben aan zee alle schelpen meegenomen, meent hij. Als de ander vraagt waarom hij toch in alles iets negatiefs moet zien, reageert hij als volgt: 
Negative? Moi? I think realistic might be a better word. You mean to tell me we can drive all the way here from L.A. and see maybe ten thousand square miles of shopping malls, and you don't have maybe just the weentsiest inkling that something, somewhere, has gone very very cuckoo? (ibid: p. 62).

Deze fascinatie met commercie en consumentisme aan de ene kant en wat daardoor verloren gaat aan de andere vinden we al in Americana (1971), de debuutroman van Don DeLillo. Daarin breekt de achtentwintigjarige David Bell met zijn succesvolle, maar oppervlakkige en al te materialistische bestaan. ${ }^{176}$ Net als Andy, Dag en Claire zoekt Bell de ruimte op. De stad is hem te vol, te gejaagd en te anoniem, het leven in de buitenwijk - het Old Holly uit zijn jeugdte conformistisch en saai. Bovendien staat het suburbane bestaan in zijn ogen voor 'the dream of the good life, innocent enough, simple enough on the surface', maar bij nader inzien een droom met een

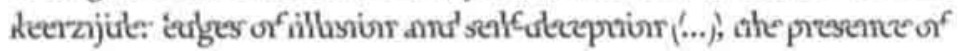
something black (...) at the mirror rim of one's awareness' (DeLillo (1990): p. 130). Bell vertelt het verhaal van een oude indiaan die hij ergens in het verlaten midden-westen ontmoet. Amerikanen zijn uit op vernietiging, stelt deze. Zowel bossen als oude huizen, schuren, kerken en stations moeten eraan geloven. Ze worden vervangen door 'tasteless identical structures. Boxes of cancer cells. Neat gray chambers for meditation and the reading of advertisements. (...) We must realize we are living in Megamerica. Neon, fiber glass, Plexiglass, polyurethane, Mylar, Acrylite' (ibid: pp. 118-9). Het ideale Amerika, vervolgt hij in steeds dystopischer termen, staat van kust tot kust vol met woningen en motels die tot in detail identiek zijn en die met elkaar zijn verbonden door zesendertigbaanssnelwegen. Met het verhaal van de indiaan pleit Bell voor bezinning. Wat hij in zijn individuele leven doet, is nodig op nationale schaal, namelijk stilstaan bij de vraag of een eenvoudiger bestaan wellicht niet wenselijker is. ${ }^{177}$ In Americana blijkt de Amerikaanse vernieuwingdrang niet los te koppelen van een terugverlangen naar wat daardoor verloren zou gaan: het minder efficiënte en nietmaterie̋le, de kleine gemeenschap, het persoonlijke, unieke en lokale. In Generation $X$ is dat niet anders. 


\subsection{Ontwrichte gezinnen}

De kleinste gemeenschap die in de problemen raakt, is het leven thuis. Er wordt wel gesproken van een epidemic of family breakdown of crisis of the family: de ontwrichting van het kerngezin. Een fraai voorbeeld is Claire's familie. Dat vader een hartaanval krijgt, laat het gezin koud, stiefmoeder wekt de indruk elk moment de kinderen te kunnen verscheuren en de kinderen onderling houden zich slechts bezig met dode beroemdheden en het einde van de wereld - 'Did Nostradamus ever say anything about random snipers? (...) Hey ... is it possible to damage the sun?' (Coupland (1995a): p. 35). Met hen heeft Claire geen enkele band. Gezinsleden, luidt haar opvatting, worden door God willekeurig uit het telefoonboek gepikt en zeventig jaar bij elkaar gezet, ook al hebben ze niets gemeen en mogen ze elkaar niet eens. Dag is vervreemd van zijn ouders. Hij kan met hen niet praten en peinst er niet over hen met kerst op te zoeken. Andy is wel van plan te gaan, maar ziet daar tegelijkertijd enorm tegen op. Hoewel hij wel degelijk van zijn ouders houdt, staan zij in zijn ogen model voor het benauwende kleinburgerlijke bestaan waarvoor hij op de vlucht is.

Ook deze tweede ontwikkeling waarmee de drie zich geconfronteerd zien, is vaker in literaire verhalen verbeeld. Wat betreft ontwrichte middle-class gezinnen bijvoorbeeld in Raymond Carvers What We Talk About When We Talk About Love (1981), wat betreft disfunctionele upper-middle-class families in Bret Easton Ellis' Less than Zero(1985). In Carvers bundel staan veelal mislukte relaties centraal, wat tot uitdrukking komt in onderhuidse spanningen, openlijke ruzies, wanhoop en eenzaamheid. In het verhaal 'Why Don't You Dance?' wordt in Carvers typische kale stijl beschreven hoe een man de inboedel van zijn huis bekijkt. Een salontafel, een televisietoestel, een platenspeler, een bankstel - niets bijzonders, alleen staan ze in de voortuin en op de inrit. Alles is te koop, ook het tweepersoonsbed met nachtkastjes aan beide kanten, 'his side, her side. He considered this as he sipped the whiskey' (Carver (1989b): p. 3). We krijgen de indruk dat de man sinds kort alleen is. Zijn vrouw is er vandoor en het huis moet worden verkocht. In deze suburbane woning heeft zich geen gelukkig gezinsleven afgespeeld, maar voltrekt zich een echtscheiding. De man kan zijn spullen niet meene- 
men. Zijn perspectief is geen grotere woning in een betere wijk, maar een kleiner onderkomen, eerder een appartement dan een vrijstaande eengezinswoning. De man merkt op dat voorbijrijdende auto's zo nu en dan vaart minderen, dat voorbijgangers naar de inboedel staren, maar dat niemand stopt. Iedereen lijkt afstand te willen houden, van een mislukt huwelijk en een gestaakte wooncarrière. Slechts een jong stel toont interesse. Het ruikt een buitenkans, omdat het veronderstelt dat de verkoper wanhopig is. ${ }^{178}$

Hoe uitzichtloos wanhoop kan zijn, blijkt in de luxe buitenwijken in Ellis' Less than Zero. We volgen het achttienjarige rijkeluiszoontje Clay dat tijdens de kerstvakantie zijn familie en vrienden in Los Angeles bezoekt. Dat is althans de bedoeling. Zijn ouders zijn nergens te bekennen, zijn vrienden zijn nauwelijks geïnteresseerd in contact. In Ellis' debuutroman heerst een schokkend gebrek aan communicatie. Er heerst slechts leegte en verveling en begrippen als 'gemeenschap', 'gezin' en 'thuis' hebben hun betekenis verloren. ${ }^{179}$ Dat blijkt nier alleen wit de vele zinloze, steeds weer ontsporende gesprekken en de gevoelloosheid van de personages, maar evenzeer uit de omgeving waarin zij hun welvarende levens leiden. Geïsoleerd in zijn auto rijdt Clay heen en weer tussen Bel Air, Westwood en Beverly Hills. Eenmaal aangekomen in een van deze in zichzelf gekeerde buurten, zoekt hij in verlaten villa's tevergeefs naar 'vrienden' en familie. Zwembaden en tennisbanen te over in dit suburbia, maar de baden zijn leeg en getennist wordt er tegen het ballenkanon. Tegen een achtergrond van een materiěle welvaart die in de loop van de jaren tachtig steeds extremer vormen aanneemt, treffen we in Ellis' roman vermogende, maar ontwrichte gezinnen aan. Zij zijn sterren in het onmiddellijk bevredigen van lusten en verlangens, maar vallen ten prooi aan totale ervaringsloosheid en bezoeken drukbezochte feestjes waar de eenzaamheid vanaf druipt. Claire's familie is niet de enige die in de suburbs rond L.A. ontspoort.

\subsection{De verdwijning van de middenklasse}

De derde belangrijke ontwikkeling die Andy, Dag en Claire bezighoudt, is wat in de sociale wetenschappen wel de disappearing middle 
class of vanishing middle wordt genoemd. In de loop van de jaren zeventig en nog sterker onder invloed van het Reaganomics in de jaren tachtig groeit de sociaal-economische boven- en onderlaag en lijkt de middenklasse te verdwijnen. Zij zou niet alleen in omvang afnemen, maar vooral ook haar overzichtelijke wereldje zien afbrokkelen en het gevoel krijgen op tal van ontwikkelingen haar greep te verliezen. In Generation $X$ wordt deze ontwikkeling in de marge onder de noemer brazilification expliciet aan de orde gesteld en typeren Andy en zijn vrienden in de hoofdvertelling hun verblijfplaats Palm Springs als een plek die geen middenklasse kent. De rijken betalen er de armen om de stekels van hun cactussen te knippen, merkt Claire op. De drie proberen zich in het vacuüm daartussen staande te houden. Ze werken op de feestjes van de rijken en verdienen daarnaast geld met wat zij McJobs noemen: "low-pay, low-prestige, low-dignity, low-benefit, no-future'-baantjes in de dienstensector (Coupland (1995a): p. 5). Waar in veel sociaal-wetenschappelijke studies de polarisatie tussen boven- en onderlaag wordt verbonden met de tegenstelling tussen blank en zwart (en andere minderheden), staat in Generation $X$ primair een tegenstelling tussen generaties centraal. De drie menen dat sociaal-economische onzekerheid vooral jongeren treft, terwijl ouderen hun schaapjes op het droge zouden hebben. Op een dag uit Dag zijn woede. Hij beschadigt een auto waarop een bumpersticker prijkt met de tekst: 'We're spending our children's inheritance' (ibid).

Ook deze maatschappelijke tweedeling is al vóór Generation $X$ in literaire verhalen verbeeld. In Ellis' Less than Zero, bijvoorbeeld, en in een groot deel van zijn latere werk, ontmoeten de rijken slechts rijken en hebben af en toe onbedoeld confrontaties plaats met de arme onderlaag. Opvallende afwezige is de middenklasse. Complexer is Harry Angstroms wereld in Updike's Rabbit-cyclus. Tegen de achtergrond van een in toenemende mate gepolariseerd Amerika bungelt Harry in de loop van drie decennia op verschillende niveaus in de middenlaag. ${ }^{180}$ Steeds zijn anderen de baas over zijn bestaan. Harry combineert verontwaardiging met afwachten, een combinatie die ook Andy, Dag en Claire typeert. Exemplarisch is Rabbits machteloosheid in Rabbit Redux (1971). De zesendertigjarige Harry, weer samen met Janice en Nelson, leidt een routineus en middelmatig bestaan in een blanke, conservatieve buitenwijk. Zijn ordelijke 
leventje wordt op zijn kop gezet als Janice ervandoor gaat, in de geest van de tijd op zoek naar een eigen identiteit. Harry neemt Jill in huis, een rondzwervend meisje met gescheiden ouders dat zich heeft gekeerd tegen het angstige establishment waarvoor Harry symbool staat. Ongevraagd trekt vervolgens Skeeter in, een zwarte jongeman die nog feller dan Jill is gekant tegen alles waar Harry voor staat. Rabbit ziet zich geconfronteerd met een bedreigende dynamiek waartegen hij weinig kan of wil ondernemen.

Zoals in het eerste deel van de cyclus, is de synecdoche de centrale stijlfiguur. Harry's verhaal is een verhaal over middle America. Een onzeker middle America dat achter de feiten aanholt, een middenlaag, in termen van Dilvo Ristoffs Updike's America (1988), 'caught in-between the forces that make history' (Ristoff (1988): p. 28). Harry's onrust vertaalt zich niet in pogingen zijn eigen bestaan een wending te geven, laat staan dat hij in het publieke domein zijn stem verheft. In die zin belichaamt hij een middenRlasse die in de loop van de jaren zeventig en tachtig in toenemende mate wordt beschouwd als speelbal van de geschiedenis. Hoewel ze hun machteloosheid anders uiten en bovendien een stuk progressiever zijn, vinden we Rabbits combinatie van frustratie en lusteloosheid terug bij de drie in Palm Springs. Ook zij besluiten niet meer mee te spelen. Gedesoriënteerd trekken ze zich terug.

\subsection{Neerwaartse mobiliteit}

In het licht van de genoemde romans en verhalen is de thematiek in Generation X niet vernieuwend. Een vierde probleem dat aan Andy, Dag en Claire's desoriëntatie ten grondslag ligt, is in de literatuur echter wel betrekkelijk nieuw: de drie zien zich geconfronteerd met een groeiende kloof tussen een traditioneel geloof in opwaartse mobiliteit en een neerwaarts mobiele realiteit. Willen we deze in context beschouwen, dan moeten we uitwijken naar sociaal-wetenschappelijke studies. Daarvoor biedt de roman ook aanknopingspunten. De appendix vol statistieken lijkt op de verantwoording in sociaal-wetenschappelijke studies, bijvoorbeeld die aan het eind van Baldassare's betoog over dynamisch postsuburbaan Californiè. De margetekst roept associaties op met hand- en studieboeken en 
bijvoorbeeld Hine's Populuxe (1986) en Duany, Plater-Zyberk en Specks Suburban Nation (2000).

Allereerst is het van belang scherp te krijgen wie met de term 'generatie X' wordt aangeduid. Waar bijvoorbeeld Scott Thomas in The United States of Suburbia (1998) spreekt van cén Suburban Generation, onderscheidt Couplands roman twee generaties. De generatic $\mathrm{X}$ is geboren in de loop van de jaren zestig en krijgt met name gestalte in contrast met de oudere garde van de zogenoemde babyboomers. Leden van de generatie X, lezen we in de marge, lijden aan boomer envy: 'envy of material wealth and long-range material security accrued by older members of the baby boom generation by virtue of fortunate births' (Coupland (1995a): p. 21). De babyboomers hebben het economisch tij mee gehad en zitten er warmpjes bij. Bovendien, is de gedachte, bezetten ze maatschappelijke sleutelposities en belemmeren ze de toetreding of doorstroming van de latere generatie. Dags arbeidsverleden biedt de beste illustratie. De babyboomgeneratie wordt belichaamd door Martin, Dags voormalige baas. Terwijl Dag en zijn leeftijdsgenoten zich geen andere woonruimten kunnen veroorloven dan 'grimy little shoe boxes' (ibid: p. 21), vertelt Martin graag over zijn nieuwe, dure huis. Een huis dat hij volgens Dag heeft gewonnen in 'de genetische loterij', alleen maar doordat hij toevallig op het juiste moment in de geschiedenis is geboren. Als hij vandaag de dag Dags leeftijd zou hebben, dan hield hij het nog geen tien minuten uit, krijgt Martin te horen. Toch zal Dag zijn hele leven Martins en 'higher-up' Martins boven zich hebben, 'always grabbing the best piece of cake first and then putting a barbed-wire fence around the rest' (ibid).

Een tweede groep waarvan de generatie X zich onderscheidt, is een jongere garde die zich in de consumptiemaatschappij die Andy, Dag en Claire ontvluchten juist thuis voelt. Vertegenwoordigers zijn onder anderen Andy's jongere broer Tyler en zijn vrienden. Zij zijn schaamteloos materialistisch en leggen ambitie aan de dag. Hun ideaal is een carrière in een groot bedrijf. Volgens Andy willen velen van hen voor гвм werken, "when their lives end at the age of twenty-five ("Excuse me, but can you tell me more about your pension plan?")'(ibid: p. 106). ${ }^{181}$

Een belangrijk verschil met deze twee groepen is dat de generatie X zo weinig mogelijk op de voorgrond treedt en zich niet of nau- 
welijks uitspreekt. Ze wordt volgens Andy gekenmerkt door haar onopvallendheid (zie ibid: p. 56 ). ${ }^{182}$ Ze trekt zich terug, verbergt zich - resignatie boven confrontatie, zo typeert Joost Zwagerman het onderscheidende kenmerk (zie Zwagerman (1995): P 32). Hij haalt de Amerikaanse schrijver David Leavitt aan, die spreekt van een nieuwe lost generation ${ }^{183}$ die is opgevoed met hoopvolle, progressieve, maar inmiddels failliet verklaarde idealen: 'overbewuste, hedonistische en vaak ook apathische twintigers en dertigers, op te jonge leeftijd geplaagd door jeugdsentiment, geïntimideerd door hardwerkende fortuinmakers en verveeld door naïeve, folkloristische wereldverbeteraars' (ibid). We hebben te maken met jonge mensen die van ideeën, idealen en ideologieën de zeer beperkte geldigheid en houdbaarheid inzien - een verschrikkelijk soort vroege wijsheid. In plaats van de confrontatie aan te gaan, bagatelliseren en ironiseren ze iedere vorm van strijdbaarheid. Ze zijn vroeg wijs misschien, maar evengoed apathisch en verveeld (zie ibid). Positief kun je hun zelfbeeld hoe dan ook niet noemen.

Generation $X$ refereert aan 'under achievement, disaffection, and apathy of white middle-class people in their twenties,' (Moore (1998): p. 253) schrijft socioloog Ryan Moore in Generations of Youth (1998). Moore plaatst uitputting en ironie in het licht van de zogeheten downward mobility waardoor de middenklasse in de loop van de jaren tachtig zou worden getroffen en, algemener, de postmoderne conditie. Onder deze laatste verstaat hij een onvermogen nog ergens sterke gevoelens voor te koesteren. ${ }^{184}$ Het ontbreekt aan criteria op basis waarvan keuzen kunnen worden gemaakt en aan voldoende grond om eventueel gekozen paden daadwerkelijk in te slaan. Om te begrijpen hoe dit de jonge middenklasse beïnvloedt, is het volgens Moore belangrijk te kijken naar neerwaartse mobiliteit. In verscheidene studies uit de jaren tachtig en negentig wordt een portret geschetst van jongeren met banen ver onder hun opleidingsniveau, met een slecht salaris, slechte arbeidsvoorwaarden en weinig carrièremogelijkheden. Opwaartse mobiliteit is nog allesbehalve vanzelfsprekend. Ook volgens Andy. De generatie X, vertelt hij, bestaat uit twintigers die kantoorfuncties vervullen zonder veel uitzicht op uitbreiding van hun takenpakket of een beter salaris. Ze zitten in sociaal-economisch opzicht gevangen, 'frozen on this awful boring ladder'(Coupland (1995a): p.56). 
Voor wat dat betekent voor de middenklasse zijn verschillende termen gemunt. 'Fear of falling' krijgt een steeds groter deel van de middenklasse in zijn greep, betoogt Barbara Ehrenreich in haar gelijknamige boek. Na een decennialange stijging van inkomens, sociale zekerheid en status, 'the ground in the middle began to tremble and crack' (Ehrenreich (1989): p. 200). In de jaren zeventig en tachtig slaat de onzekerheid toe. De middenklasse vreest een downward slide. In Falling from Grace (1988) en Declining Fortunes (1993) verzamelt antropologe Katherine Newman verhalen van mensen die een stap terug hebben moeten doen. Ze beschouwt deze in het licht van belangrijke Amerikaanse culturele narratieven die we in hoofdstuk 2 en 3 tegenkwamen, zoals die rond inzet, opwaartse mobiliteit en succes. Tot de jaren tachtig, schrijft ze, is de middenklasse de groep bij uitstek met een rotsvast geloof in de American dream, gebaseerd op het aloude vertrouwen in de mogelijkheid vooruitgang te boeken. Dat elke generatie het beter zal hebben dan de vorige is in de middenklasse niets minder dan een geloofsartikel, stelt ze (zie Newman (1988): pp. 8-11 en (1993): pp. 211-2). De naoorlogse, decennialange welvaartsstijging sterkt de middenklasse in deze overtuiging. 'They (...) "had it made",'schrijft Newman. 'They found a place higher up the ladder in this society and then, inexplicably, found their grip loosening and their status sliding' (Newman (1988): p. 8). Niet alleen de sociaal-economische positie, ook het gevoel van zeggenschap over het eigen leven komt daardoor in gevaar. In de Amerikaanse cultuur zijn nauwelijks verhalen voorhanden die betekenis geven aan een stap terug. 'Falling from grace,' concludeert Newman, resulteert in een symbolische leegte die leden van de middenklasse richtingloos en machteloos achterlaat en hun soms zelfs hun gevoel van eigenwaarde kost.

Dat geldt in het bijzonder voor jongeren, voegt ze daaraan in 'Uncertain Seas' (1991) toe. ${ }^{185} \mathrm{Zij}$ ervaren een 'slowdown, and in many cases a reversal, in the life chances $(. .$.$) for career advancement,$ economic stability, and secure membership in the middle class' (Newman (1991): p. 113). Opgegroeid in de verwachting opwaarts mobiel te zullen zijn, is voor velen downward mobility de realiteit: 'they will never see the occupational trajectory or lifestyle that their parents took for granted' (ibid). ${ }^{186}$ Neerwaartse mobiliteit, betoogt Moore, versterkt de postmoderne uitputting die hij onder deze jon- 
geren signaleert. Een van de invloedrijkste grote verhalen in de Verenigde Staten - de bijna vanzelfsprekende koppeling tussen vooruitgang op macroniveau en verbetering van de eigen positie - verliest zijn geloofwaardigheid. Een belangrijk onderdeel van het traditionele oriëntatiekader gaat daarmee verloren. 


\section{Time-out}

Aan de milieu- en gezinsproblematiek en de machteloosheid van de verdwijnende middenklasse zoals die in de literatuur zijn verbeeld, voegt Generation $X$ de tendens van neerwaartse mobiliteit uit sociaal-wetenschappelijke studies toe. Samen vormen ze een achtergrond waartegen Andy, Dag en Claire's gevoel van onzekerheid en richtingloosheid niet verwonderlijk is. Duidelijk is dat ze op de geschetste ontwikkelingen geen antwoord hebben. Van hen valt in elk geval ter verklaring geen groot verhaal te verwachten en evenmin hevig verzet. In die zin kunnen we hun houding een postmoderne noemen. In de marge rond Andy's vertelling krijgt deze uitdrukking. In plaats van overgeleverde tradities en religie fungeert het personal tabu als leidraad: 'a small rule for living, bordering on a superstition, that allows one to cope with everyday life in the absence of cultural or religious dictums' (Coupland (1995a): p. 74). Enorme keuzemogelijkheden leiden tot option paralysis: 'the tendency, when given unlimited choices, to make none' (ibid: p. 139). En in de plaats van politieke strijd komt het voter's block: 'the attempt, however futile, to register dissent with the current political system by simply not voting' (ibid: p. 8o). Ook op hun afgenomen sociaal-economische kansen reageren de drie niet met uitgebreide analyses, maar met korte, soms ironische, soms wanhopige typeringen. Een antwoord op een leven met Mcjobs, bijvoorbeeld, is lessness: 'a philosophy whereby one reconciles oneself with diminishing expectations of material wealth'(ibid: p. 54).

Het is verleidelijk Andy, Dag en Claire's houding met bijvoorbeeld Zwagerman en Moore 'apathisch' of 'passief' te noemen. Bovendien verleidt ook Newmans betoog - net als dat van Fishman over de verdwijnende middenklasse in hoofdstuk 3 - de jonge middenlaag op te vatten als een verslagen groep, een groep die maatschappelijk buitenspel is komen te staan. Newman voert haar op als 
een weak generation. Deze maakt geen vuist, beschouwt zichzelf nauwelijks als actor op het sociaal-politieke toneel: 'responding to (...) trends and events rather than seizing the opportunity to impose their own interests on the historical landscape' (Newman (1993): p. 205). Newman zet een wereld neer waarin jongeren zoals de drie in Palm Springs in zwaar weer een schuilplaats zoeken. De sfeer is dreigend. In de 'gathering economic storm' (ibid: p. 189) voelt de jonge middenklasse zich in haar schuilplaats 'both trapped and scared'(ibid: p. 208). Ze wordt overweldigd. In de economie regeren krachten die ze niet begrijpt, laat staan beheerst. Newman voert de invisible hand op, niet in de klassieke rol waarin deze alles in goede banen leidt, maar als een kracht die op macroniveau de beslissingen van individuen bepaalt, hun persoonlijke leven in haar greep houdt (zie ibid: p. 212). Newmans metafoor laat de jonge middenklasse weinig mogelijkheden. 'Unseen hands' zijn meer dan een abstracte economische kracht. De jonge generatie 'feels strangled' (ibid) - ze zit klem en haar angst is begrijpelijk: ze wordt gewurgd. ${ }^{187}$

Andy en zijn vrienden wachten af en houden zich stil, zeker, maar zijn ze ook willoze slachtoffers? $\mathrm{Na}$ halfslachtige pogingen om mee te komen in de ratrace kiezen ze bewust voor een plek in de marge van de samenleving. Ze trekken zich terug, wat wel degelijk een vorm van handelen is. Als plek in de woestijn is Palm Springs in deze beweging zowel aankomstplaats als uitvalsbasis. Andy en zijn vrienden komen er op adem na een vlucht voor een bestaan dat ze deels onwenselijk achten, deels wel zouden willen leiden, maar daartoe de mogelijkheid niet meer krijgen: een leven geregeerd door de jacht op status, overdadige consumptie en vervuiling, maar ook een leven in een rustig gezin, met sociale zekerheid en carrièrekansen. Als uitvalsbasis is Palm Springs een tijdelijke halte die de drie gebruiken om erachter te komen wat zij wel waarderen en wat wel binnen hun bereik ligt. Ze weten min of meer wat ze willen: een hernieuwde balans tussen materieel bezit en immaterięle waarden, een hechte band met gelijkgezinden en tijd om stil te staan bij kleine, alledaagse gebeurtenissen en objecten. Maar vooralsnog slagen ze er niet in ook maar een begin te maken met concrete realisatie van hun dromen. De periode die Andy, Dag en Claire in Palm Springs doorbrengen, is, kortom, het beste op te vatten als een timeout, een fase tussen een bestaan dat niet meer mogelijk of wenselijk 
is en een leven dat nog slechts in vage termen kan worden geschetst en waarvoor de bestaansvoorwaarden duidelijk nog niet zijn gerealiseerd. De drie nemen een time-out - Palm Springs mag dan in de periferie liggen, het is zeker geen willekeurige plek: ze is goed gekozen, vervult voor de drie een belangrijke rol. 
Waar veertigers politieke idealen nastreven, yuppies geld en succes najagen en twintigers zoals Andy's jongere broer Tyler schaamteloos materialistisch zijn, trekken Andy, Dag en Claire zich terug. Palm Springs is een bijzondere plaats. 'There is no weather in Palm Springs - just like rv,' vertelt Andy. 'There is also no middle class, and in that sense the place is medieval' (Coupland (1995a): p. 10). Daarmee is de belangrijkste reden gegeven waarom de drie deze plek een geschikt toevluchtsoord vinden: 'the town is undoubtedly a quiet sanctuary from the bulk of middle-class life' (ibid). Andy en zijn vrienden beschouwen de ontwikkelingen rond milieu, gezin, zeggenschap en mobiliteit als een middenklasseproblematiek. Te midden van korte typeringen - zoals reinvent the middle class en Dags keuze voor een souterrain, omdat de lucht bovengronds te veel naar de middenklasse riekt-legt met name Andy uit wat er mis is.

Allereerst zijn er zijn ouders in een buitenwijk van Portland. Twee lieve mensen, maar volgens Andy verlamd van angst voor verstoring van de status-quo. Verkrampt steken ze al hun energie in het tegengaan van verandering:

they will manufacture talismans against it (...). They will putter away inside the house until the future, like a horrible diseased drifter, breaks its way inside and commits an atrocity in the form of death or disease or fire or (this is what they really fear), bankruptcy. The drifter's visit will jolt them out of complacency; it will validate their anxiety. They know his dreadful arrival is inevitable (...). And they know that he owns no land and that he won't discuss TV and that he'll trap the sparrows inside the birdhouse with duct tape. But they won't talk about him (ibid: p. 144) ${ }^{188}$ 
Hoewel deze ouders het beste voorhebben met hun kinderen, is geen van Andy's broers en zussen echt gelukkig geworden, vertelt Andy. Schrijnend is het contrast tussen hun huidige levens en een foto die vijftien jaar eerder van het gezin is gemaakt. Als foto van een gezin met frisgewassen haren en fonkelende tanden is ze in al haar perfectic al die jaren de norm geweest waaraan elk van hen heeft trachten te voldoen. Zonder succes. Geen van hen is in staat gebleken een 'normaal' middenklassebestaan te leiden. Andy vertelt hoe het gezin op de foto naar rechts kijkt, naar wat de toekomst lijkt, maar uiteindelijk een loze belofte is gebleken. ${ }^{189}$ Dit jaar gaat hij met kerst met tegenzin naar huis en komen zijn broers en zussen niet eens opdagen. Ze hebben besloten hun pogingen te staken.

Bovendien zijn er Andy's vrienden van vroeger. Zijn moeder vertelt over een afspraak tussen ouders om elkaar niet meer te vragen naar de kinderen, om niet weer over teleurstellingen te hoeven spreken: 'they all look so beaten, so old now - so prematurely middleaged' (ibid: p. 138). Andy's eigen oordeel liegt er evenmin om. Hij brengt zijn vrienden onder in drie categorieën: getrouwd, vervelend en gedeprimeerd; alleenstaand, verveeld en gedeprimeerd; en gevlucht om aan verveling en depressiviteit te ontsnappen. Wie een huis heeft gekocht, is er misschien nog wel het slechtst aan toe. Een eigen huis staat volgens Andy niet alleen garant voor saaie televisieavonden, maar vooral ook voor geldgebrek vanwege torenhoge huizenprijzen en noodgedwongen gebondenheid aan vreselijke banen. In de marge worden deze vrienden gerekend tot een subgroep van de generatie X: squires 'exist almost exclusively in couples and are recognizable by their frantic attempts to recreate a semblance of Eisenhower-era plenitude in their daily lives in the face of exorbitant housing prices and two-job life-styles' (ibid: p. 135). Squires zijn voortdurend uitgeput door hun hebzuchtige speurtocht naar meubels en gadgets. Ze kiezen voor een middenklassebestaan naar traditioneel model, in een tijd waarin het volgens Katherine Newman geen haalbare kaart meer is. Na het einde van de 'gospel of upward mobility' ligt een eigen huis - symbool bij uitstek voor de stabiele middenklassestatus - buiten hun bereik ${ }^{190}$ : voor steeds meer jonge leden van de Suburban Generation blijken de poorten van de buitenwijk gesloten (zie Newman (1991): p. 122). Afgepeigerd door al hun streven, zijn ze bovendien niet eens blij met hun woning, voegt 
Andy toe. Hun weinige gelukkige momenten ontlenen ze aan dromen over zogenoemd upgraden, het volgens velen typische middenklasseverlangen naar groter en comfortabeler wonen.

Deze vrienden komen niet zelf aan het woord. Het is Andy die, soms ironisch, maar vaak ronduit somber en zelfs gefrustreerd, hun leven inkleurt. Net als dat van zijn ouders, broers en zussen duidt hij het in termen van verstikkende normen en verwachtingen enerzijds en het onvermogen en de onwil daaraan te voldoen anderzijds. Duidelijk is dat in Andy's optiek de prijs voor het suburbane middenklassebestaan te hoog is. Zelfs een bijzonder moment op eerste kerstdag, aan het eind van zijn korte verblijf thuis, verandert daar niets aan. Integendeel. Andy heeft's ochtends in alle stilte in de woonkamer honderden kaarsen ontstoken. Het effect is overweldigend: 'this light (...) making the eyes of my family burn, if only momentarily, with the possibilities of existence in our time' (Coupland (1995a): p. 146). Maar na afloop gaan zijn ouders en Tyler onmiddellijk over tot de orde van de dag. Zijn moeder zet koffie, zijn vader schakelt de rookmelders uit, zijn broer stort zich op zijn kerstcadeaus - 'New skis! I can die now!' (ibid: p. 147). Voor Andy is dit aanleiding zijn onbehagen expliciet onder woorden te brengen. 'It is a feeling that our emotions, while wonderful, are transpiring in a vacuum, and I think it boils down to the fact that we're middle class,'analyseert hij.

You see, when you're middle class, you have to live with the fact that history will ignore you. You have to live with the fact that history can never champion your causes and that history will never feel sorry for you. It is the price that is paid for day-to-day comfort and silence. And because of this price, all happinesses are sterile; all sadnesses go unpitied (ibid).

In plaats van steun te krijgen van het referentiekader waarbinnen hij is grootgebracht, beseft Andy dat hij het te lang met zich heeft meegetorst. 


\section{Verlangen naar toekomst}

Palm Springs - weg van het middenklasseleven met al zijn verwachtingen en teleurstellingen, weg van zoveel mogelijk overbodige producten en apparaten - lijkt in het licht van Andy's opvattingen een geschikt toevluchtsoord. Toch blijkt het lastiger dan gedacht het overgeleverde middenklassekader af te werpen. We zouden de trek naar de periferie zelfs kunnen vergelijken met een vlucht die zo lang is uitgelegd als typerend voor de middenklasse: die naar suburbia. Andy, Dag en Claire's levenswijze aan de rand van de woestijn vertoont veel kenmerken die traditioneel worden geassocieerd met het leven in de buitenwijk. Ze vormen een homogene gemeenschap op afstand van het drukke, snelle leven elders. Ze zijn gelijkgezind, hebben vergelijkbare inkomens, bevinden zich in dezelfde levensfase, zijn allen blank en verlangen naar een overzichtelijke orde en rust. Een deel van Richard Sennetts kritiek op de buitenwijk die in het vorige hoofdstuk aan de orde was, lijkt van toepassing op de levensstijl van de drie. Andy's expliciete doel is zijn leven te 'decompliceren', volgens Sennett het kenmerk van de zowel adolescente als suburbane neiging het leven overzichtelijk te maken. De drie vormen een hechte en intieme gemeenschap waarin ze zich afzonderen van de complexe en bedreigende buitenwereld. ${ }^{191}$ Zo bezien, krijgt hun poging het spel niet meer mee te spelen het aanzien van een herhaling van zetten. Zelfs in de woestijn blijkt het moeilijker dan gedacht van gebaande paden af te wijken.

Andy en zijn vrienden houden behoefte aan de orde en stabiliteit uit het middenklassekader waaruit ze trachten te ontsnappen. Zolang ze niet in staat zijn een alternatief te formuleren dat ook op langere termijn levensvatbaar is, blijft hun verblijf in Palm Springs gekenmerkt door het gevoel van onzekerheid waaraan ze nu juist een einde willen maken. Sterker nog, meer dan wat ook verlangen ze zelfs naar een van de belangrijkste elementen uit het middenklasse- 
bestaan waarvan ze afscheid trachten te nemen: vertrouwen in de toekomst. Om deze cruciale paradox helder te krijgen, zullen we het verblijf van de drie in Palm Springs niet alleen moeten beschouwen als een vlucht in de ruimte en een verandering van levensstijl, maar vooral als een poging te komen tot een nieuwe temporele oriëntatie.

\subsection{Een preoccupatie met tijd}

Allereerst valt op dat de drie gedurende hun verblijf in Palm Springs een bijzondere belangstelling aan de dag leggen voor alles wat te maken heeft met het verstrijken van tijd. In de marge geven tal van termen hieraan uitdrukking. Voorbeelden zijn kreten als stop history en nostalgia is a weapon en neologismen als historical underdosing en overdosing, historical slumming, vaccinated time travel, decade blending en now denial (ibid: pp. 7, 8, 11, 15, 40, 41, 151), waarvan sommige uitdrukking geven aan onvrede met het heden en andere aan het verlangen daaraan op verschillende manieren te ontsnappen. Ook Andy laat in zijn verhaal regelmatig zijn gedachten gaan over verleden, heden en toekomst. Hij weet weinig positiefs te melden. 'Echte geschiedenis', vertelt hij bijvoorbeeld,'genuine capital $H$ history', heeft hij nauwelijks meegemaakt. Geschiedenis in zijn tijd, zonder hoofdletter, is volgens hem niet meer dan een 'press release, a marketing strategy, and a cynical campaign tool'(ibid: p. 151). Even negatief is hij over het verloop van tijd in het individuele leven. In oude foto's, bijvoorbeeld, ziet hij niet alleen onschuld, ze maken hem ook treurig. Op het moment dat ze worden genomen, namelijk, is de toekomst nog onbekend en moet ze ons nog kwetsen (zie ibid: p. 17). Andy is in dit opzicht zwaarder op de hand dan Dag en Claire. Hij voelt zich bijvoorbeeld niet in staat net als zij vrijelijk te experimenteren met kledingstijlen uit verschillende perioden 'using time as a color' of 'time cannibalizing' (ibid: p. 15) zoals zij het noemen. 'I have enough trouble just being now,' bekent hij. ' 1 dress to be obscure, to be hidden - to be generic. Camouflaged'(ibid). 


\subsection{Vertellen over tijd}

De preoccupatie met tijd blijkt ook uit de verhaaltjes die de drie elkaar vertellen. De toonzetting is afwisselend humoristisch en somber, ironisch en nostalgisch. Een constante is de bescheidenheid waarmee ze worden verteld en bovendien hun verstilde karakter, de rust en gelatenheid die ze uitstralen. Als zodanig fungeren ze als een vorm van tijdrekken in een versnelde cultuur. Maar de vertellingen zijn veel meer dan een vertragingstactiek. Voor de drie vormen ze de belangrijkste methode van heroriëntatie. Met hun verhalen creëren Andy en zijn vrienden een wereld waarin ze zich, hoe tijdelijk ook, thuis kunnen voelen. In Palm Springs verblijven de drie, maar onderdak vinden ze in de verhalen die ze vertellen. Deze verhalen bieden hun de bescherming die ze nodig hebben in hun poging opnieuw richting te geven aan hun leven. Belangrijk is de onderlinge afspraak dat degene die aan het woord is, niet mag worden onderbroken of gekritiseerd. Zo geven de drie elkaar de gelegenheid voor de duur van een verhaal een gevoel van zeggenschap te hervinden dat ze in de buitenwereld zijn kwijtgeraakt. ${ }^{192}$

Zoals in het margelexicon en in Andy's overpeinzingen, staat ook in deze verhalen veelvuldig een bepaalde kijk op tijd centraal. Net als Andy toont Dag zich weinig optimistisch. Hij vertelt graag zogenoemde 'end-of-the-world stories' - 'eschatological You-AreThere accounts of what it's like to be Bombed, lovingly detailed and told in deadpan voice' (ibid: p. 62). Dag roept hierin het einde van de wereld op. ${ }^{193} \mathrm{Hij}$ haalt de in zijn ogen immer dreigende toekomst met een ruk naar voren, om haar als een gitzwart heden present te stellen. Zijn verhaal is een gedachte-experiment waarin een aanvankelijk normale situatie onder extreme druk komt te staan. Wat doen consumenten bijvoorbeeld, vraagt Dag zich af, als tijdens een dagelijks bezoek aan een supermarkt een kernoorlog uitbreekt, 'collapsing and confusing both time and space' (ibid: p. 63)? Hoe gedraagt het winkelend publiek zich als het einde der tijden zich niet na een, relatief gemakkelijk te verdringen, langzame aftakeling van het milieu aandient, maar na een even onverwachte als onontkoombare nucleaire catastrofe? Naast de voor de hand liggende paniek levert dat onverwachte gedragingen op die in het licht van het nabije einde gewicht krijgen. In de rij voor de kassa staat bijvoor- 
beeld een dikke man met een overvolle winkelwagen voor je, vertelt Dag. ${ }^{194}$ Terwijl raketten worden afgeschoten en de gevreesde sirenes loeien, vertelt de dikke man heel rustig over zijn voornemen zich waardig te gedragen als dit moment zich zou aandienen. Hij wil daarom betalen voor zijn boodschappen en net voor De Flits vraagt hij de caissière zijn geld te accepteren. Daarnaast is er je beste vriend. Juist voordat de ramen imploderen en het plafond smelt, juist voordat een hagel van kauwgom en tijdschriften door de winkel schiet en de dikke man in brand vliegt, besluit hij je op je mond te kussen. Zo, zegt hij, dat heb ik altijd al willen doen. Dag manipuleert in zijn verhaal op een bepaalde plaats de tijd - hij schrapt hier de toekomst - en schept zo voorwaarden waaronder zich onvermoede mogelijkheden kunnen aandienen. Deze kunnen Dag en zijn vrienden helpen bepalen waar het in hun leven om draait. In deze supermarkt, bijvoorbeeld, gaat achter de consumptiegekte die Dag verafschuwt - onder meer present in de vorm van grote flessen cola en liters spaghettisaus - meer warmte en waardigheid schuil dan gedacht.

Een tweede voorbeeld van een verhaal waarin op een bepaalde plek een tijd gestalte krijgt die de drie helpt vast te stellen wat hun opties zijn, komt van Claire. Wat zij vertelt, speelt zich af in Texlahoma:

a sad Everyplace, where citizens are always getting fired from their jobs at the 7 -Eleven and where the kids do drugs and (...) fantasize about being adult and pulling welfare-check scams as they inspect each other's skin for chemical burns from the lake water. (...) Texlahomans (...) shoot each other over Thanksgiving dinners every year. (...) Life is boring there(...)(ibid: p. 39).

In dit zelfverzonnen plaatsje is het milieu vervuild en verliest de middenklasse haar baan. Afgezien van heimelijke seksuele avontuurtjes valt er niets te beleven en er heerst een benauwende sfeer die zo nu en dan uitmondt in huiselijk geweld. Als een suburb buiten de stad bevindt Texlahoma, een asteroïde, zich op afstand van de aarde. Het is er permanent 1974, licht Andy toe, het jaar na de oliecrisis en het jaar waarna de reële inkomens in de Verenigde Staten maar niet meer wilden stijgen. 'It's a fun place to spend one day, 
and then you just want to get the hell out of there' (ibid: p. 40).

Zoals in de seventies-buitenwijken in Jeffrey Eugenides' The Virgin Suicides (1993) en Rick Moody's The Ice Storm (1994) ${ }^{195}$, blijkt in het Texlahoma uit Claire's verhaal ontsnappen aan het middelmatige middenklassebestaan uitermate lastig. Het ruimtevaartuig van astronaut Buck is niet opgewassen tegen de zwaartekracht van Texlahoma. Buck ziet zich gedwongen te landen in de suburbane achtertuin van de familie Monroe. Eenmaal beneden, blijkt opstijgen onmogelijk. Blij met zijn gezelschap vraagt mevrouw Monroe Buck samen met haar spelshows te kijken op televisie. Wat een rustig suburbaan middagje had kunnen worden, blijkt het begin van een langer verblijf in Texlahoma. Buck wordt ruimteziek en valt in een diepe slaap. Om te ontsnappen, heeft hij de hulp nodig van de Monroe-zusjes Arleen, Darleen en Serena. Eén voor één vraagt Buck hun hem te helpen door met hem op te stijgen en Texlahoma te verlaten. Arleen en Darleen wijzen zijn aanbod af als zij horen dat zij door gebrek aan zuurstof aan boord zullen sterven. Dat Buck hen na aankomst op de maan weer tot leven kan wekken, geloven zij niet. Serena echter, heeft het helemaal gehad met de oersaaie, eeuwige stilstand in het God-forsaken Texlahoma van 1974. Zij laat zich verleiden door Bucks beschrijvingen van planeten die zij nog nooit heeft gezien. Dat ze haar ontsnapping hoogstwaarschijnlijk met de dood moet bekopen, aanvaardt ze. Om te ontkomen aan de herhaling en verveling in deze middenklassesuburb, zo kunnen we de moraal van Claire's allegorie interpreteren, is Serena bereid een hoge prijs te betalen. Haar verlangen te ontsnappen is zo groot dat ze liever de dood riskeert dan nog één dag langer in Texlahoma te blijven.

Serena's keuze contrasteert scherp met die van de achtergebleven zusjes. Terwijl de raket in een lange rechte baan wegschiet en uiteindelijk verdwijnt, luisteren Arleen en Darleen naar het geknars van de kettingen van de schommel waarop ze zitten. Ze houden een wedstrijdje wie het hoogst komt, maar zullen telkens weer omlaag worden getrokken. Ze verzekeren elkaar dat Bucks belofte hen weer tot leven te wekken onzin was, maar zijn desalniettemin jaloers op de vertrokken Serena. Haar droom mag dan misschien niet zijn uitgekomen, ze sterft wel met een aantrekkelijk toekomstperspectief voor ogen. 
Om die toekomst gaat het uiteindelijk. Andy, Dag en Claire's probleem is er primair een van een gebrek aan verwachtingen. Ze zijn opgevoed in een tijd waarin de Amerikaanse droom een leidende gedachte was. Bovendien leek realisatie daarvan de gewoonste zaak van de wereld. Wie in de tijd van hun ouders hard werkte, kon morgen een eigen huis kopen en het eventueel overmorgen alweer verkopen, omdat door tal van carrièrekansen een grotere woning binnen handbereik lag. In het verwachtingspatroon waarmee de drie zijn grootgebracht, maken de vergrotende en overtreffende trap de dienst uit: naast 'groot-groter-grootst' ook 'nieuw-nieuwer-nieuwst' en 'groen-groener-groenst'. Elke generatie zou het beter hebben dan de vorige en in het individuele leven zou wat vandaag is gezaaid morgen kunnen worden geoogst. De drie is veel beloofd. De vraag is wat er in hun optiek van al die hooggespannen verwachtingen is terechtgekomen.

Dag en Claire vertellen hun verhaaltjes tijdens een zogenoemde 'picnic in hell', waarbij de hel West Palm Springs Village is - 'a bleached and defoliated Flintstones color cartoon of a failed housing development from the 1950s' (ibid: p. 14). Dit is niet zonder betekenis. In een tijd van grote vraag naar onroerend goed, is deze plek een waar curiosum, merkt Andy op: een moderne ruĭne en vrijwel verlaten. Het betreft een project uit de jaren vijftig dat juist voordat het zou worden opgeleverd, werd afgeblazen. Het gebouwde is nooit in gebruik genomen en daardoor in de loop der tijd niet aangepast. Het oorspronkelijke plan, het ideaal, is door de tijd niet aangetast. Wat opvalt, is hoezeer het optimisme uit de jaren vijftig - waarvan de drie zich een voorstelling trachten te maken - in de hedendaagse omgeving detoneert. Alles is anders gelopen dan voorzien. In 'alternately forked universes' zouden hier de riante huizen hebben kunnen staan van filmsterren, vertelt Andy. In dit 'more welcoming universe' zouden zijn vrienden zijn uitgenodigd voor drankjes met de kleur van een 'Hollywood, California sunset' (ibid: p. 16). In werkelijkheid hebben straten als Sapphire Avenue hun glans verloren. De palmbomen zijn dood, het asfalt verkeert in staat van ontbinding en is overwoekerd door struikgewas. In het universum van de drie is het ideaal van weleer op deze plaats letterlijk fail- 
liet gegaan. Wat het verleden hun aanlevert, is een vervallen en verlaten, dor landschap.

Als de drie vooruitkijken, ontbreekt het hen aan vertrouwen. Om dat terug te winnen, zijn ze op zoek naar toekomst. Om deze gestalte te geven, biedt het naargeestige heden hun weinig aanknopingspunten. In dit opzicht belichaamt West Palm Springs Village het probleem dat ook in Ehrenreichs en Newmans studies centraal staat. De jonge generatie, betoogt Newman bijvoorbeeld, 'had been promised only sunshine and good times but were greeted instead by doubledigit unemployment' (Newman (1993): p. 189). De economische neergang in de jaren tachtig betekent voor de meesten niet direct armoe, maar wel cen afscheid van allerlei dromen en aspiraties (zic ibid: pp. 130, 212). Ook Stephanie Coontz spreekt in The Way We Never Were (1992) niet in termen van 'het goed of slecht hebben', maar van de hoop 'het beter te krijgen' of juist de verwachting dat 'het slechter wordt'. De financièle positie van veel gezinnen in de jaren vijftig en zestig was misschien verre van ideaal, maar velen waren optimistisch, omdat ze toenemende mogelijkheden in het vooruitzicht hadden. 'If we once had long range optimism in the midst of short-range hardship,' betoogt ze, 'today we have long-term despair in the midst of short-term benefits' (Coontz (1992): p. 257). ${ }^{196}$ 'What remains for many is a sense of quiet despair and faint hope,' concluderen ook Rosalyn Baxandall en Elizabeth Ewen - 'the future is in doubt' (Baxandall en Ewen (2000): p. 236). Als vertegenwoordiger van de jonge generatie laten zij Ron Rosenbaum aan het woord. In zijn perspectief herkennen we dat van Andy en zijn vrienden. Zelfs zijn hippe lingo zou zo het hunne kunnen zijn: 'Now there's an unmistakable sense of a lost future (...), a peeling-vinyl, soiled-astro turf, diminished vision of the future that is one so much less than the one we were promised, the one we longed for' (ibid: p. 237). ${ }^{197}$ Ook hij spreekt van verwarring, van een stuurloosheid die volgt op teleurstelling en ontgoocheling en het besef zich opnieuw te moeten oriënteren.

Andy, Dag en Claire oriënteren zich door terug te kijken. Ze grijpen terug op de beloften waarmee ze zijn grootgebracht en die in de tijd van hun ouders uitkwamen. Ze verlangen naar de toekomst uit het verleden. Dag geeft als eerste uitdrukking aan dat verlangen. Tijdens een meningsverschil met Andy geeft hij zich bloot. Het is Andy die de confrontatie zoekt en Dag omschrijft als 
someone whose entire sense of life begins and ends in the year his own parents got married, as if that was the last year in which things could ever be safe, (...) someone who dresses like a General Motors showroom salesman from the year 1955 . And Dag, have you ever noticed that your bungalow looks more like it belongs to a pair of Eisenhower era Allentown, Pennsylvania newlyweds than it does to a fin de siècle existentialist poseur? (...) You have Danish modern furniture; you use a black rotary-dial phone; you revere the Encyclopedia Britannica. You're just as afraid of the future as my parents (Coupland (1995a): p. 85).

Dag antwoordt dat Andy wel eens gelijk kan hebben. Misschien is het wel zo dat hij zijn toevlucht zoekt in een geïdealiseerd, veilig verleden, geeft hij daarmee impliciet toe. Misschien klopt het wel dat hij zich oubollig kleedt en zich omringt met ouderwetse objecten om een illusie van zekerheid en voorzichtig optimisme te creëren, een gevoel dat voor hèt pasgetrouwdè ftfties-stel dät Andỳ opvoert, zo vanzelfsprekend was. Hij keert zich tegen zijn ouders. 'I want to tell them that I envy their upbringings that were so clean, so free of futurelessness. And I want to throttle them for blithely handing over the world to us like so much skid-marked underwear' (ibid: p. 86). Dag beschuldigt zijn ouders niet alleen, hij geeft ook toe jaloers te zijn, op hoe zij volwassen werden, in zijn ogen in een stralende tijd, een tijd met een toekomst.

Ook Andy uit zijn onzekerheid door te klagen over zijn ouders. Daarnaast richt hij zich, zoals we hebben gezien, tegen de squires onder zijn leeftijdsgenoten en tegen zijn jongere broer Tyler en diens vrienden. Deze laatsten lijken in tegenstelling tot Andy probleemloos te functioneren binnen de versnelde cultuur waarin zij zijn opgegroeid en lijken bovendien niet bang ambitieus te zijn. Ze dragen dure merkkleding, vluchten niet in drugs of ironie en durven ervoor uit te komen zelfs een carrière te ambiëren bij een 'vervuiler' als Union Carbide. Dat ze als twintigers al bezig zijn met hun pensioenvoorziening jaagt Andy angst aan. Hij kritiseert hen, maar geeft net als Dag toe hen te benijden. Hun keuze is niet de zijne, maar de rust die zij uitstralen, doordat zij hun bestaan richting kunnen geven, zou ook in Andy's leven meer dan welkom zijn. ' 1 'm just jealous of how unafraid Tyler's friends are of the future,' geeft 
hij toe. 'Scared and envious' (ibid: p. 138), zoals ook Dag niet alleen bang is, maar vooral ook jaloers op de toekomst die zijn ouders in zijn ogen altijd voor zich zagen.

Waar Andy en zijn vrienden naar verlangen, is die toekomst, een horizon die veel weg heeft van wat filosoof Rein de Wilde in De voorspellers (2000) een 'wenkende toekomst' noemt. Wie leeft met dit perspectief, staat positief ten opzichte van wat nog moet komen. De toekomst houdt een belofte in, van nieuwe kansen op een beter leven en grotere handelingsvrijheid. Daartegenover staat in De Wilde's betoog de 'aanstormende toekomst'. Deze wenkt niet, maar komt op ons af. Van haar gaat dreiging uit. Ze kan zelfs paniek veroorzaken (zie De Wilde (2000): pp. 83-6). Toch is dit niet het type toekomst waarmee de drie zich geconfronteerd zien. Wat in hun herinneringen, opvattingen en verhalen opvalt, is dat ze geen van beide toekomsten vóór zich zien. Dit perspectief, of het gebrek daaraan, resulteert in de onzekerheid die hen naar Palm Springs heeft gebracht. En zonder baken ontbreekt het de drie aan het vertrouwen en richtingsgevoel dat nodig is om daar weer te vertrekken. De leegte die Andy en zijn vrienden voor zich zien, kunnen we een 'wijkende toekomst' noemen. Als zij vooruitblikken, krijgen ze geen beeld voor ogen. ${ }^{198}$ Niet in hun bestaan voordat ze de periferie opzochten en nog steeds niet als ze daar hun time-out nemen. 


\section{De woestijn door,}

\section{naar het beloofde land}

Onder woorden brengen wat ze van de toekomst verwachten en verlangen, blijkt voor de drie een opgave van formaat. Met de verhalen die ze elkaar vertellen doen ze voorzichtig pogingen, maar zolang vertellen hun belangrijkste vorm van handelen is, blijft elke nieuwe versie van de toekomst een kwetsbaar en vluchtig narratief. Desondanks winnen ze door hun verkenningen in deze verhalen geleidelijk aan zelfvertrouwen en durven ze het aan uit Palm Springs te vertrekken om een stap voorwaarts te zetten. Op een ochtend zijn Dag en Claire verdwenen. Ze zijn vertrokken naar San Felipe, Baja Californiẻ in Mexico. Ze willen er een hotel beginnen, een toekomstdroom waarover Dag zijn vrienden eerder heeft verteld. Blijkbaar acht hij de tijd rijp zijn woorden in daden te vertalen. Doordat Andy's vertelling stopt voordat hij Dag en Claire in Mexico ontmoet, weten we niet of de drie het hotel daadwerkelijk van de grond krijgen. Hoewel niet onmogelijk, is dat niet waarschijnlijk. Dags ideeën vallen nauwelijks om te zetten in een levensvatbaar ondernemingsplan. Zijn hotel is slechts bedoeld voor vrienden en excentriekelingen, het moet worden gerund door mooie jongens en meisjes met door dope aangetaste breinen, en gasten die een mooi verhaal vertellen, mogen gratis overnachten. ${ }^{199}$ Het plan lijkt een typische uiting van wat in de marge terminal wanderlust heet: 'a condition common to people of transient middle-class upbringings. Unable to feel rooted in any one environment, they move continually in the hopes of finding an idealized sense of community in the next location' (Coupland (1995a): p. 171). Zoals veel ouders voortdurend de ene suburb voor de andere verruilen, hun werk achterna en op weg naar steeds grotere huizen, zijn hun kinderen op zoek naar weer een andere, hopelijk betere plaats om neer te strijken.

Noch in Andy's verslag van zijn reis naar Mexico, noch in de laatste verhalen die hij vertelt, vinden we zo'n plek. San Felipe heeft hij 
zo geïdealiseerd dat het alleen nog maar kan tegenvallen. ${ }^{200} \mathrm{Het}$ woestijnlandschap op weg ernaartoe is te bar en verlaten om er uberhaupt te kunnen verblijven. Het is slechts geschikt om doorheen te trekken, wat precies is wat Andy doet, en vermoedelijk zal blijven doen. Toch slaagt hij erin moed te houden. Zijn verslag van zijn tocht naar de Mexicaanse grens drukt ondanks alles hoop uit. Die ontleent hij niet aan de middenklassebeloften rond suburb, gezin en carrière, noch aan een nieuw referentiekader dat hun plaats kan innemen. Wat Andy in zijn laatste verslag op de been houdt, is een aantal klassieke culturele narratieven: de frontiermythe en een reeks religieuze verhalen die Andy in de context van het hedendaagse Amerika hervertelt en actuele betekenis geeft.

Aangekomen aan de westkust, het traditionele eindpunt in de frontier-traditie, is verder westwaarts trekken uitgesloten. Dan maar in zuidelijke richting naar de grens. Ook een barre tocht, maar in tegenstelling tot eerdere avonturiers beschikt Andy over een auto met de kofferbak vol flessen Evian en pillen tegen diarree - 'certain bourgeois habits die hard', geeft Andy toe (ibid: p. 169). We verlaten hem op het moment dat hij in het hete Calexico in een file voor de Mexicaanse grens staat te wachten. Hij omschrijft de zesbaans corridor als een 'linear space', waarmee hij een contrast schept met de kleine kring in Palm Springs, Texlahoma's eeuwige 1974 en het open-neer van de achtergebleven zusjes op hun suburbane schommel. In deze ruimte kan vooruitgang worden geboekt, is de suggestie. 'I lurch forward,' vertelt Andy, 'one car's length closer to the border one unit closer to a newer, less-monied world where a different food chain carves its host landscape in alien ways I can scarcely comprehend'(ibid). Bovendien is het nieuwjaarsdag. De tijd is rijp voor iets nieuws.

Over wat hij die dag beleeft, vertelt Andy een verhaal vol symboliek. Wat hij vertelt en vooral hoe hij dat doet, straalt uit wat ook de tales van de drie in Palm Springs uitstralen. Veel van de religieuze, of quasi-religieuze, beelden die ook elders in Couplands werk vallen aan te treffen (zie Wesseling (2000)), zijn in Andy's laatste verhaal vertegenwoordigd. Allereerst bereikt hij na een tocht over droge en schrale vlakten Imperial County: 'America's Winter Garden', een uitermate vruchtbaar landschap. Het is alsof hij na een verblijf in de woestijn aankomt in het beloofde land. Als hij in een van de vele boom- 
gaarden rond het plaatsje Mecca stiekem een sinaasappel plukt, gooit de boer die hem betrapt hem er nog een toe. Dat gebaar maakt indruk. 'A farmer's forgiveness felt very absolute,' vertelt Andy (Coupland (1995a): p. 175).

$\mathrm{Na}$ deze vergiffenis wacht hem een bovenaards schouwspel, een visioen dat afkomstig lijkt uit een van Dags doemscenario's. Een gitzwarte thermonucleaire wolk vult de horizon. ${ }^{201}$ Geen twijfel mogelijk, denkt Andy, dit is de wolk die hij altijd heeft gevreesd. Hij raakt in paniek en wacht op de sirenes. Het blijft stil. De stratosferische paddestoel blijkt afkomstig van in brand gestoken boerenland. $\mathrm{Er}$ is een onaards landschap ontstaan, 'a supergravitational blackness', 'accidental wonder' en 'marvel of antipurity' (ibid: p. 177). Andy komt daarin tot rust. Hij is niet alleen ontzettend opgelucht, het ontzag dat het gebodene inboezemt, brengt hem en andere omstanders dichter bij elkaar. Bovendien gaat Andy's diepste verlangen in vervulling. Waar Claire ervan droomt in de woestijn op zoek te gaan naar water en Dag door een engel hoopt te worden meegenomen naar de zon, komt in Andy's droom een pelikaan aanvliegen die hem een visje offreert - een offerande waarvoor hij alles zou opgeven. Boven het zwartgeblakerde veld is het een witte reiger, een vogel die volgens Andy cerder thuishoort boven de Ganges of de Nijl dan in Amerika. De toeschouwers voelen zich uitverkoren. En dan, plotseling, alsof de tijd zijn tempo iets heeft opgevoerd, vertelt Andy, scheert de vogel over zijn hoofd. Zijn huid wordt opengereten en Andy, die beseft hoe direct het contact is geweest, valt op zijn knieën. Nauwelijks bekomen, voelt hij vervolgens twee armen om zich heen. Ze zijn van een verstandelijk gehandicapt meisje, in een hemelsblauwe jurk, dat hem met een gebedsgenezend gebaar troost. Voordat hij het goed en wel beseft, vallen andere kinderen uit haar groep over hem heen en weet hij zich omhelsd door 'an instant family (...), adoring, healing, (...) this crush of love (...) unlike anything I had ever known' (ibid: p. 179).

Wat zich leek aan te dienen als het einde mondt uit in een loutering. Deze gebeurtenis lijkt misschien op de kerkbrand in Couples' Tarbox, maar waar Piet Hanema afscheid neemt van suburbane spelletjes, is het Andy in zijn postsuburbane misère ondanks de nodige ironie steeds ernst geweest. De gebeurtenissen in dit apocalyptische landschap mogen dan misschien maar even duren, de rust 
en het geluk die Andy ervaart, betekenen een breuk met een sombere periode. Zoals hij aan het begin van de roman in het donker zit te wachten op zonsopgang, zo kondigt de witte vogel op deze nieuwjaarsdag tegen een zwarte achtergrond een nieuw begin aan.

Dit biedt geen garanties. Andy beseft dat het landschap, voornamelijk in overdrachtelijke zin, voorbij de grensovergang verandert. Waar het aan Amerikaanse zijde groen, vruchtbaar en voedzaam is, wordt het in Mexico een maanlandschap: 'granular, parched, and desperate' (ibid: p. 172). Daar zullen de drie hun plannen moeten realiseren. ${ }^{202}$ Bovendien beseft Andy dat een vertaalslag noodzakelijk is, wil hij steun ontlenen aan de traditionele vertellingen waarop hij in zijn laatste verslag teruggrijpt. Hij maakt daarmee al tijdens zijn vertelling een begin. Wellicht door zijn ervaring met de verhalen in Palm Springs heeft hij weinig moeite het hogere, symbolische, tijdloze een plaats te geven in een uitdrukkelijk alledaagse en hedendaagse context. De Apocalyps, bijvoorbeeld, is in zijn verhaal een nucleaire catastrofe en ook de traditionele kleur van onschuld, reinheid en maagdelijkheid krijgt een hedendaags tintje: de vogel is cocaĩne-en vliegtuig-wit. Bovendien staat Andy nadrukkelijk stil bij het soort mensen dat tot de uitverkorenen behoort. Naast de verstandelijk gehandicapten in hun schoolbus staan gezinnen in campers met ruziënde kinderen en vertegenwoordigers die in de auto hamburgers eten uit de magnetron van de 7-Eleven. Een blik op de rij waarin Andy uiteindelijk voor de grens staat te wachten, maakt duidelijk dat dit de sociale en materiêle omgeving is waarin hij en zijn vrienden zullen moeten werken aan hun perspectief. Andy mag dan geïnspireerd zijn door het hogere, zijn toekomst begint in een file op een bloedheet, versleten wegdek in dieseldamp, tussen getatoeëerde boeren in pickup trucks, Ray-Banned yuppies in geblindeerde sedans en huisvrouwen met krulspelden in Hyundai's vol stickers. 


\section{Conclusie}

Puttend uit verschillende tradities zet Generation $X$ een snel veranderende Amerikaanse samenleving en cultuur neer waarin drie jonge leden van de middenklasse gedesoriënteerd afhaken. De hoofdvertelling laat zich lezen als een combinatie van de traditionele coming-of-age en road story, waarin een reis door de Amerikaanse ruimte tevens een persoonlijke zoektocht betekent. Wie er genoeg van heeft, zoals bijvoorbeeld Updike's Rabbit en DeLillo's David Bell, verlaat huis en haard en begeeft zich, letterlijk, op weg. Dat is riskant, maar houdt tegelijkertijd een belofte in: een nieuwe omgeving met nieuwe ervaringen als voorwaarde voor persoonlijke groei en een nieuw bestaan. 'I needed a clean slate,'(ibid: p. 31) vertelt Dag over zijn komst naar Palm Springs. 'Wiping the slate clean', stellen Ron Eyerman en Orvar Löfgren, is een klassiek onderdeel van wat in Amerika moving on heet. $\mathrm{Zij}$ schetsen een traditie waarin naast de frontier-mythe romans als John Steinbecks The Grapes of Wrath (1939) en Jack Kerouacs On the Road (1957) een plaats krijgen, een traditie van moving forward en taking to the road (zie Eyerman en Lögren (1995): pp. 55-73). In de loop van de jaren tachtig breekt hierin een nieuwe fase aan. De tijd waarin risico en hoop hand in hand gingen, is voorbij, betogen Eyerman en Löfgren. Wie op weg gaat, neemt nog wel de risico's, maar moet het stellen zonder de verwachting dat aan het eind een beter leven wacht.

Het lexicon in de marge van de hoofdvertelling en de appendix met cijfers en statistieken plaatsen deze verandering in een verklarend en kritisch kader en voorzien haar van een sociaal-wetenschappelijk aandoende onderbouwing. In de context van studies als die van Newman en Ehrenreich kunnen we spreken van een generatie met middenklasse-idealen die door haar ouders zijn gerealiseerd, maar die in de loop van de jaren tachtig in toenemende mate onhaalbaar blijken - deze generatie is een eigen, vrijstaande woning 
en opwaartse mobiliteit beloofd, maar ze ziet haar dromen steeds vaker in rook opgaan. We kunnen Andy, Dag en Claire beschouwen als jonge leden van een onzeker middle America, in Ristoffs termen 'caught in-between the forces that make history'. Met Moore, tot slot, zouden we de drie kunnen opvatten als leden van een generatie die zich stilhoudt en terugtrekt, die grote moeite heeft keuzen te maken en gekozen paden daadwerkelijk in te slaan. Andy, Dag en Claire lijken hun problemen te ontlopen. Niet alleen door uit te wijken naar de periferie, maar ook door bescherming te zoeken in de wereld die de drie in hun verhaaltjes oproepen. Het is verleidelijk in het verlengde van Fishmans betoog te concluderen dat de jonge, blanke middenklasse die Andy en zijn vrienden vertegenwoordigen van het maatschappelijk toneel verdwijnt.

In dit hoofdstuk werd duidelijk dat Couplands roman mogelijkheden biedt deze verleiding te weerstaan. De diagnose in Generation $X$ is niet nieuw. De meerwaarde zit hem met name in de wijze waarop de diagnose wordt gesteld en hoe de reactie daarop uitdrukking krijgt. In Generation $X$ wordt van binnenuit inzichtelijk hoe Andy, Dag en Claire's versie van de wereld in elkaar steekt. De verhalen, kreten, toelichtingen en getallen uit Andy's vertelling, het margelexicon en de appendix krijgen betekenis doordat ze onderling verwijzen. Zo roepen ze een gesloten wereld op. We worden meegenomen in een universum waarin pessimisme het dominante perspectief is en waarin een alternatief niet eenvoudig voorhanden blijkt. Begrijpelijk wordt waarom de jonge middenklasse voor wie de poorten van suburbia gesloten blijken, niet zomaar met angst en wanhoop kan afrekenen en waarom woedend of nostalgisch terugblikken eenvoudiger is dan vormgeven aan een nieuwe toekomst. Bovendien bleek dat de keuze van de drie voor een time-out in de marge geenszins inhoudt dat zij uit het verhaal worden weggeschreven. Integendeel. Wat de roman toont, is welke overwegingen en activiteiten juist in de marge mogelijk worden. We hebben gezien hoe aarzelend en voorzichtig de drie te werk gaan, hoe bescheiden zij zich uitdrukken en hoeveel moeite het hen kost een klein stapje vooruit te zetten. Generation X slaagt erin de voorwaarden te scheppen waaronder zo' $n$ bescheiden geluid hoorbaar en zulke omzichtige handelingen zichtbaar worden.

Palm Springs speelt hierbij een centrale rol. We kunnen het, in 
termen van hoofdstuk 4, beschouwen als de centrale chronotoop in Couplands roman. Het verhaal is georganiseerd rond het verblijf van de drie op deze plek aan de rand van de woestijn. Niet alleen doet Andy er verslag van hun dagelijkse bezigheden en uitstapjes, ook hun herinneringen aan hun vorige levens en hun verwachtingen van wat nog komen moet, komen in Palm Springs bijeen. Als plaats in de periferie speelt het in het leven van de drie een cruciale rol. Niet als de plek waar ze zich permanent zullen vestigen, maar juist als tijdelijke halte. Andy en zijn vrienden proberen er afscheid te nemen van een in hun optiek verwerpelijk bestaan - geregeerd door status, concurrentie, prestatie en overmatige consumptie - en een bestaan dat buiten hun bereik is komen te liggen - georganiseerd rond de vrijstaande woning, een stabiel gezin, sociale zekerheid en carrièrekansen. Naast aankomstplaats is Palm Springs een uitvalsbasis, op weg naar een leven waarin de drie zich wel thuis voelen en waarin voor hen wel plek is. In Palm Springs nemen ze een time-out. Al pratende gaan ze op zoek naar bouwstenen voor een nieuw referentiekader waarin ze weer met enig vertrouwen verwachtingen kunnen koesteren. De drie benutten Palm Springs als een plaats voor temporele heroriëntatie. Daaraan gepaard gaat een zoektocht naar een nieuwe levensstijl en identiteit. Andy en zijn vrienden nemen de ruimte om daarmee, al doende, te experimenteren. In de marge heeft een mislukking niet de consequenties die ze in de ratrace ongetwijfeld wel zou hebben. Bovenal tasten ze hun mogelijkheden af in verhalen. Voor hun bungalows, aan het zwembad en in de hel van West Palm Springs Village durven de drie al vertellende initiatief te nemen en ervaren ze een gevoel van zeggenschap en controle. In en door hun verhalen voelen ze zich beschermd. Zoals Sheherazade met haar sprookjes in Duizend-en-en-nacht, weten Andy, Dag en Claire zich met hun tales staande te houden. Bovendien verzamelen ze moed. Met allegorieën als diagnose, sprookjes als therapie en scenario's als gedachte-experiment bereiden ze zich voor op vertrek uit Palm Springs. Of ze elders hun plannen kunnen realiseren, blijft onzeker, maar Andy's laatste verhaal stemt in elk geval hoopvol. Het is de vraag of hij ook tussen vertegenwoordigers en yuppies, hamburgers en krulspelden, pickup trucks en spiegelruiten de rust weet te bewaren, zeker is wel dat hij voldoende vertrouwen heeft om cen grens te passeren en verder te trekken. 
Fishmans verdwijntruc en het getouwtrek en de stemverheffing van lobbygroepen en verenigde huiseigenaren in bijvoorbeeld Kling, Olin en Posters Postsuburban California (1991) en Davis' Ecology of Fear (1998) blijken niet de enige bijdragen aan het debat over de rol van de middenklasse in een laat- of postsuburbane tijd. Binnen het beschermende kader van de raamvertelling krijgt in Generation $X$ een voorzichtige en moeizame poging tot heroriëntatie uitdrukking. Te midden van verhalen en betogen waarin de jonge leden van de middenklasse worden voorgesteld als speelbal van de geschiedenis is dit een bijzondere bijdrage. Katherine Newman mag dan stellen dat 'America's younger boomers have found themselves with no voice at the very time when they have the most to scream about,' (Newman (1993): p. 211) in Generation X kunnen we Andy, Dag en Claire horen fluisteren. Zij mogen dan onzeker en teleurgesteld zijn, hun generatie mag in studies als die van Ryan Moore zelfs apathisch heten, in Couplands roman tonen zij zich uiteindelijk opmerkelijk opgewekt. 



\section{6}

Een eendagswijk

Een spel met conventies in Couplands

'Brentwood Notebook' 



\section{Inleiding}

Van de jongste geschiedenis van suburbia bestaan verschillende versies. Omdat het ontstane gedecentraliseerde, multifunctionele metropolitane gebied niet meer in termen van de klassieke dichotomie 'stad - buitenwijk' zou kunnen worden gevat, is het einde van de suburb aangekondigd. In andere geschiedenissen wordt niet gesproken van een radicaal nieuwe techno-city, maar hebben ingrijpende veranderingen geresulteerd in transformed suburbs of een postsuburban region. In weer andere, tot slot, zijn de Verenigde Staten suburbaner dan ooit. Een titel als The United States of Suburbia is volgens deze opvatting meer dan een aardige woordspeling: in de buitenwijk woont het grootste deel van de Amerikanen en in de buitenwijk worden, bijvoorbeeld, de verkiezingen beslist.

Niet alleen het bestaan en de aard van de suburb staat op het spel, maar meer in het algemeen ook opvattingen over wat 'plaats' nog inhoudt, en in het verlengde daarvan bijvoorbeeld 'gemeenschap'. Wordt bijvoorbeeld gedacht in termen van een netwerk waarin verschillende plekken als knooppunten met elkaar zijn verbonden, dan verdringen noties als 'verplaatsing', 'reistijd' en 'nomadisme' 'plaats' vaak naar de achtergrond. Het polycentrische netwerk heet dan bijvoorbeeld een non-place urban field. Gaat de aandacht sterker uit naar een bepaalde plek in de grootstedelijke omgeving, dan kan 'plaats' wel degelijk een belangrijke notie zijn. Knooppunten blijken dan niet inwisselbaar. Op deze plaats, hier, is bijvoorbeeld een gemeenschap ontstaan die op die plaats, daar, ondenkbaar is. En, op deze plek verdedigen we onze levensstijl en identiteit, die plek vermijden we. 'Centrum' en 'periferie' mogen dan problematische concepten zijn geworden, denken in termen van 'afstand' en 'afscherming', maar ook 'veilig' en 'onveilig', 'drukte' en 'rust' is onverminderd populair.

In Generation X (1991) vertelt Andy dat het er vandaag de dag niet 
meer zoveel toe doet waar iemand vandaan komt. Overal immers dezelfde winkels in de mini-mall, aldus zijn broer Tyler. In 'Two Postcards from the Bahamas' uit Couplands bundel Polaroids from the Dead (1996) neemt de verteller een vergelijkbaar standpunt in. “"Place" is a joke' (Coupland (1997): p. 112), lezen we op een van de ansichtkaarten. In andere stukken uit de bundel doen plaatsen er wel degelijk toe. In het essay over de Lions Gate Bridge, bijvoorbeeld, is deze brug in het Canadese Vancouver niet zomaar een stuk infrastructuur, maar een wezenlijk onderdeel van de identiteit van de verteller, Coupland zelf. En in het essay over het Californische Palo Alto wordt dit stadje niet opgevoerd als een van de vele knooppunten in Silicon Valley - in Fishmans geschiedenis de archetypische technoburb-, maar als een van de weinige plekken waar de middenklassedroom nog steeds lijkt uit te komen.

Palo Alto is where rv's Brady Bunch would have lived (and still might): amid the Arcadian suburban foliage (...). Its twenty-six square miles are a gracious and charming place in which to live, and there are no caveats on enjoyment of the place. (...) It is the embodiment of middle-class tranquility and freedom. It is Palo Alto (...) that lurks in the back of many minds as the ideal that is worth fighting for when fighting is called for (ibid: pp. 115-6).

Beide opvattingen van 'plaats' krijgen uitdrukking in het slotstuk van Polaroids from the Dead. In 'Brentwood Notebook: A Day in the Life: August 4, 1994' schetst Coupland een portret van een van Los Angeles' upper-middle- en upper-class buitenwijken. Brentwood wordt opgevoerd als een non-place, een plek zonder duidelijke grenzen en zonder geschiedenis, waarmee bewoners zich nauwelijks verbonden voelen. Tegelijkertijd zet Coupland de buurt neer als een gemeenschap die plaats geen grap vindt, maar bittere ernst. De Brentwoodians in zijn notebook beschouwen hun buurt niet als onderdeel van groot L.A., maar kiezen voor isolement. Hoewel ze er formeel deel van uitmaken, willen ze niet opgaan in de sprawling metropool. In een tijd waarin L.A. als exopolis suburbia voorbij lijkt, wordt op deze plek de suburbane droom gekoesterd. Bevochten, beschermd, beveiligd.

'Brentwood Notebook' maakt deel uit van een zeer diverse bun- 
del. In de meeste stukken in Polaroids from the Dead is een concrete gebeurtenis of plaats aanleiding voor abstracter overwegingen over uiteenlopende thema's: ouder worden en de dood, herinnering en geheugenverlies, media en roem, technologie en consumptie, identiteit en gemeenschap. Verscheidene van deze thema's worden in het sluitstuk over Brentwood hernomen. Coupland zet de buurt neer als een gemeenschap die exemplarisch is voor de snelle Amerikaanse westkust. Ze kan worden beschouwd als belichaming van een extreem moderne of postmoderne samenleving en cultuur aan het cind van de twintigste ceuw. Brentwood staat voor materialisme, onmiddellijke bevrediging van oppervlakkige verlangens, een alomtegenwoordige beeldcultuur en een op hol geslagen modecyclus. 'If one does not change mates, religions, hairdos, bodies, politics or residence periodically,' schrijft Coupland, 'the secret and vaguely pejorative assumption among natives is: That person really isn't trying' (ibid: p. 189). Dit resulteert in een fascinerende opeenvolging van trends, levert gestaalde lichamen op en een zorgvuldig vormgegeven woonomgeving, maar niet zonder dat daarvoor een prijs wordt betaald. Tot voor kort stonden onder meer traditie, religie, familie, politieke opvattingen, klasse en plaats garant voor een coherente identiteit. Die tijd is voorbij, suggereert Coupland. In elk geval op deze plek aan de westkust. 'In Brentwood one sees a certain blankness in the eyes, and if not a blankness, then a wanting, as though some form of information has been deleted'(ibid: p. 185).

In het Brentwood uit Couplands notebook ontbreekt het aan continuïteit en coherentie, zowel in het leven van individuele bewoners als in de gemeenschap. ${ }^{203}$ Zoals veel van Couplands romans en verhalen - naast Generation X bijvoorbeeld '1, ooo Years' uit Life After God (1994), Microserfs (1995), Miss Wyoming (2000) en All Families are Psychotic (2001) - is 'Brentwood Notebook' een stuk over identiteit, in dit geval hecht verbonden met tijd. Het is een portret van een buitenwijk waarin bewoners slechts een gemeenschap vormen zolang ze zich verenigen in hun verzet tegen veranderingen die van buitenaf hun suburbane droom bedreigen. Niemand lijkt echt geïnteresseerd in de wijk, maar grenzen worden streng bewaakt. Velen verdienen hun geld in dynamisch medialand, in Brentwood streven zij stilstand na. In de wijk bewaken zij niets minder dan perfectie, maar gelukkig lijkt niemand. 
Brentwoodians krijgen deze identiteit aangemeten in een allesbehalve traditionele tekst. De temporele structuur van 'Brentwood Notebook' - vijf dagdelen van 4 augustus 1994 - mag dan suggereren dat Coupland verslag doet van wat hij gedurende een dag heeft gezien in de wijk, duidelijk is dat hij niet alleen put uit eigen observatie. Hij kijkt niet alleen, hij leest ook veel. In zijn portret herkennen we onder andere fragmenten uit tijdschriften, advertenties, memoires, een sociaal-wetenschappelijk betoog en een menukaart. Zijn notebook is een fascinerend construct. Het wekt de indruk een realistisch portret te zijn van een buitenwijk, maar verbergt niet dat het uit tal van beschrijvingen, betogen, citaten, opinies en verhalen is opgebouwd. Bovendien brengt het deze uiteenlopende fragmenten niet bijeen in een stuk dat zich eenvoudig bij een genre laat indelen. Sociaal-wetenschappelijke en literaire tradities raken vervlochten. 'Brentwood Notebook' houdt het midden tussen een reportage, een betoog en een verhaal. Impressies worden afgewisseld door argumenten, argumenten maken plaats voor suspense. Het makt de lezer alert. We worden niet alleen uitgenodigd te letten op wat we te zien krijgen, maar evenzeer op hoe het tot stand komt.

Om dat wat en hoe te achterhalen, zullen we de verleiding moeten weerstaan de structuur van het notebook als leidraad te nemen. In plaats van met Coupland van de ochtend tot de nacht van 4 augustus door Brentwood te wandelen, zal ik in zijn beeld van de wijk een aantal structurerende elementen onderscheiden die niet onmiddellijk zichtbaar zijn. Tegelijk met deze deconstructie van Couplands portret laten zich van Brentwood gezichten reconstrueren met elk een eigen uitstraling. Het ene keert zich van ons af, het andere lacht ons vriendelijk toe en weer een ander vertoont uitermate grimmige trekken. 


\section{Brentwood bestaat niet}

Brentwood bestaat niet, schrijft Coupland op de eerste pagina van het notebook. Het is slechts een postcode: 90049. De heuvelachtige suburb is niet autonoom, maar maakt deel uit van West Los Angeles. Brentwood bestaat natuurlijk wel. Er staan grote huizen van rijke mensen, Marilyn Monroe stierf er en de O.J. Simpson-moorden werden er gepleegd. Toch is de wijk op geen landkaart te vinden. Slechts de torens van het ABC Entertainment Center in Century City, de oceaan en de Santa Monica Mountain Range canyons geven Brentwood 'a notion of geographical "place-ishness"' (Coupland (1997): p. 149). Er blijkt bijna niemand te vinden die kan aangeven waar de wijk begint en eindigt. Bovendien is onduidelijk waar Brentwood zijn naam vandaan heeft: '(...) it emerged $e x$ vacuo in 1907' (ibid: p. 151). In tegenstelling tot buren als Bel Air en Beverly Hills is van de wijk geen geschiedenis geschreven. Het hele archief in Brentwood past volgens Coupland met gemak in één doos. De wijk is blijkbaar niet geïnteresseerd in haar verleden, zet het niet in om zichzelf een identiteit aan te meten. 'Brentwood is a place that has never thought of itself as even existing. That is part of its charm, its attraction'(ibid: p. 161). Het koestert geen herinneringen, schrijft Coupland. Het lijkt zelfs te lijden aan een collectief geheugenverlies. Toon je interesse in Brentwood, dan is de eerste reactie: 'But there is no history', gevolgd door een wantrouwend 'How come? How can you care about a place that doesn't even exist?' of 'You mean this counts as a place?' (ibid: p. 162).

Symbolisch is het nieuwe J. Paul Getty Center op een heuveltop buiten Brentwood. Het museum is nog geen deel van het leven in de wijk en zal dat waarschijnlijk ook nooit worden, betoogt Coupland. 'It does not collect twentieth-century art (...)' (ibid: p. 168). Het verleden wordt op veilige afstand weggestopt tussen de muren van een museum: 'the Getty atop its hill acts as a stunning metaphor for the 
weight of history placed in a location that is silently and willfully antagonistic toward recognizing history's flow'(ibid). Het besef dat het ooit anders was en dat het, erger nog, ooit weer anders zal zijn, is niet welkom.

Naast een plek zonder 'hier' en 'toen' is Brentwood een plaats waar 'straks' wordt geweerd. Waar het museum de grens symboliseert die het verleden niet mag overschrijden, trekt een grote begraafplaats een lijn ten opzichte van de toekomst. Op twee manieren belemmert Los Angeles National Cemetery, ten oosten van de 405 Freeway, verandering. Ten eerste is het, net als alle begraafplaatsen, een laatste rustplaats. Er liggen tachtigduizend mensen begraven. Bovendien is er geen plaats meer vrij, zodat er hier niets meer zal veranderen. Coupland omschrijft het terrein als 'a landscape of utter uneventfulness' (ibid: p. 194). Ten tweede heeft het een eigenschap die in L.A. uitermate schaars is: 'undevelopability' (ibid: p. 196). De bestemming van het land ligt vast, waardoor projectontwikkelaars het niet kunnen ombouwen tot woonwijk of shopping mall. Los Angeles National Cemetery is een toonbeeld van inertie. De begraafplaats is 'uitontwikkeld'. Met haar ligging, grootte en functie houdt ze de grondprijs in Brentwood hoog en functioneert ze bovendien als buffer tussen deze rustige wijk en haar veel extravertere buren Westwood en Beverly Hills en de dynamiek van Interstate 405 .

In Couplands notebook komt de tijd in Brentwood op 4 augustus 1994 tot stilstand. Gisteren en morgen kunnen of mogen er niet bestaan. De wijk kijkt niet om naar het verleden en als ze al verwachtingen uitspreekt voor de toekomst, dan houden die een verlangen in naar handhaving van de status-quo. Tijd, als ontwikkeling, bestaat in de wijk niet: Brentwood leeft in een statisch heden. 


\section{Brentwood bestaat, maar is onzichtbaar}

Naast 'willful ignorance of history' kenmerkt 'rejection of reflection' (ibid: p. 156) de wijk. Overdag, schrijft Coupland, wordt de wijk voornamelijk bevolkt door de winkelende vrouwen op San Vicente Boulevard. Zij worden omgeven door mooie acteurs en slanke actrices die zich op hun gemak van audities naar de fitnessclub begeven: 'a soap opera terrarium of post-humanized objects of desire pantherishly released in the boudoir' (ibid: p. 148). Zij belichamen de illusie van het niet-gejaagde bestaan in deze wijk. Gewerkt wordt er aan de overkant van Interstate 405. Coupland illustreert Brentwoods liefde voor rust met een opsomming van reacties op verstoring ervan, een lijst zoals ook vaak valt aan te treffen in sociologische studies van suburbaan verzet tegen verandering en groei. ${ }^{204}$ In 1975, schrijft Coupland, breekt er paniek uit als San Vicente Boulevard een highway dreigt te worden genoemd. Huizenbezitters weten in 1977 te voorkomen dat langs Sunset een freeway wordt aangelegd die door het centrum van Brentwood is gepland. Een jaar later besluiten de leden van Brentwood Park Homeowners Association nog slechts twee film shoots per woning per jaar toe te staan. En sinds 1991 mogen bladeren met niet meer dan 65 decibel geluid worden weggeblazen.

Met deze handhaving van rust toont Brentwood een tweede gezicht. Het krijgt reliëf doordat Coupland de buurt neerzet als een buitenwijk die zich twee opdringerige buren van het lijf tracht te houden: buurwijken als Beverly Hills en de stad Los Angeles. De eerste vooral om hun imago, de tweede ook in fysieke zin. Brentwood ervaart Los Angeles als bedreiging. Als luxe, ruime en leefbare wijk presenteert het zich als een schitterend alternatief voor de op vele punten uit de hand gelopen stad. Coupland neemt in zijn notebook passages op uit Mike Davis' City of Quartz (1990), waarmee hij aansluiting zoekt bij de langlopende discussie over de relatie tussen 
stad en buitenwijk waarin L.A. een hoofdrol speelt. Als symbool voor ongebreidelde sprawl vrezen suburbs de metropool. Met name buurten waarin de rijken zich hebben teruggetrokken, zijn bang te worden opgeslokt, met alle grootstedelijke gevolgen van dien. Wat hen vooral zorgen baart, is de kwaliteit van de leefomgeving op de lange termijn en de prijzen van hun huizen op de korte. Coupland citeert uit Davis' boek een drietal 'feiten' met betrekking tot het leven in de betere buitenwijken van L.A.. Eén: huiseigenaren houden van hun kinderen, maar nog meer van de waarde van hun eigendom. Twee: gemeenschap betekent homogeniteit van ras, klasse en vooral huizenprijzen. Drie: de invloedrijkste sociale beweging in hedendaags Southern California wordt gevormd door de welvarende huizenbezitters die de waarde van hun huizen en de exclusiviteit van hun buurt bewaken. Met het citaat zet Coupland Brentwood neer als een exclusieve, op behoud en bescherming gerichte buitenwijk. Ook in Brentwood, suggereert hij, is onroerend goed het onderwerp van gesprek. Brentwoodians hechten groot belang aan een goede infrastructuur, hoge grondprijzen en strenge beveiliging (zie Coupland (1997): p. 158). Hun wijk wordt opgevoerd als de vlees- (en steen-, staal- en gras-)geworden vlucht voor stedelijke wanorde. Brentwood tracht te ontsnappen. Het heeft zich doelbewust een transparant profiel aangemeten, schrijft Coupland. Door zich te verbergen, probeert het aan de alomtegenwoordige metropool te ontkomen.

Los Angeles without sci-fi-caliber infrastructure is not only unimaginable but impossible. (...) Brentwood's infrastructure is seamless. Its invisibility and fail-proofness all add to the utopian claim of the place. (...) A strong component of Brentwood's identity is that the area acts as a temporary respite from the infrastructural omnipresence of Los Angeles. (...) Entering Brentwood is like reading a book where the capitalization periods and commas suddenly vanish (ibid:pp.163-4)

Brentwood houdt een landelijke illusie in stand. Bomen zijn daarvoor volgens Coupland van groot belang. Ze scheiden de rijken van de armen en verhogen de prijs van de grond. Bovendien onttrekken ze transformatorhuisjes, elektriciteitspalen en andere smetten aan 
het zicht, waarmee ze bijdragen aan 'the dream of American Arcadian living' (ibid: p. 163) en Brentwoodians sterken in hun opvatting dat 'heaven is manufacturable' (ibid: p. 164). De hemel is groen. Het is de kleur van de eucalyptus, het gazon, de peer en de vijg die Coupland om zich heen ziet. Maar ook de tennisbaan, de brievenbus, de Jaguar en Jeep Cherokee zijn groen. De wijk maskeert de anwezigheid van technologie, maar is ondertussen van diezelfde technologie afhankelijk om de bucolische illusie overeind te houden.

'In Brentwood, infrastructure is present precisely through its lack of presence,' schrijft Coupland (ibid: p. 164). De wijk tracht te schitteren door afwezigheid. Ze verbergt zich niet alleen voor alomtegenwoordig L.A., maar houdt zich eveneens schuil voor haar rijke buurwijken. Brentwood probeert zoveel mogelijk low profile te zijn. Het biedt de rijken een riant onderkomen, maar houdt de aandacht die zij met zich meebrengen zoveel mogelijk buiten de deur. Vanuit Hollywood en Bel Air gaan steeds meer beroemdheden in Brentwood op zoek naar rust en privacy. Het is veel introverter dan bijvoorbeeld Beverly Hills. 'It is as though to live in Brentwood, one signs a covenant of invisibility,' stelt Coupland (ibid: p. 162). De wijk doet er alles aan om geen aandacht op zich te vestigen. Brentwood bestaat, maar wil onzichtbaar zijn. Wat de inwoners O.J. Simpson kwalijk nemen, is dat hij het convenant heeft geschonden. De plaats van het delict zal de komende honderd jaar een toeristische attractie zijn, voorspelt Coupland. De moord zal van Brentwood een plaats maken waar iets is gebeurd, een plek die interessant is voor mensen van buitenaf. Actrice Michelle Pfeiffer is uit voorzorg al verhuisd. 


\section{Brentwood als utopie en dystopie}

\subsection{Brentwood als utopie}

De presentatie van Brentwood leunt in Couplands notebook zwaar op een aantal traditionele motieven uit de verbeelding van suburbia. Er komt een plaats- en tijdbeeld tot stand waarin we zowel het pastorale tempo, de pittoreske omgeving als de paradijselijke perfectie uit hoofdstuk $\mathbf{z}$ herkennen. Wat past in de klassieke sjabloon van ideaal suburbia wordt in 'Brentwood Notebook' uitgelicht. De wijk belichaamt de droom van het arcadische leven, schrijft Coupland. Hij noemt haar een 'Edenic locale' (ibid: p. 163) en meet de variatie aan planten en bomen breed uit. Daarnaast besteedt hij uitgebreid aandacht aan het comfortabele karakter van het leven in de buurt. Hij presenteert luxe goederen, advertenties voor dure producten en namen van gerenommeerde bedrijven. Deze worden uitgebreid onder elkaar opgesomd voor een maximaal effect. Bovendien wordt voortdurend benadrukt dat Brentwoodians bovenal waarde hechten aan stabiliteit, veiligheid, orde en privacy. De suggestie is dat zij niets aan het toeval overlaten.

Tegenover deze behoefte aan beheersing staat traditioneel grootstedelijke chaos. Zoals we in hoofdstuk 2 zagen, leunt ideaal suburbia op de negatieve representatie van de stad. Het negatief van Brentwood is uiteraard L.A.. Als geen ander figureert de stad in doemverhalen. Na lange tijd de belofte van het betere leven in een nieuw en zonovergoten land te hebben belichaamd, wordt de City of Dreams in toenemende mate geassocieerd met uiteenlopende nachtmerries. In verschillende varianten van een angstaanjagend scenario voor de toekomst van de stad - zelfs van stedelijke toekomst in het algemeen - staan naast ongebreidelde groei onder meer toenemende sociaal-economische polarisatie en dreigende etnische onlusten centraal. Met steeds dezelfde strekking: er dreigt een cata- 
strofe. L.A., stelt Reyner Banham in zijn klassieke Los Angeles: The Anchitecture of Four Ecologies (1971), staat bekend als 'the harbinger of universal urban doom'(Banham (1971): p. 24). ${ }^{205}$

Als Coupland stelt dat inertie de strijd uiteindelijk zal verliezen van dynamiek (zie Coupland (1997): p. 196), dan plaatst hij de stabiliteit van de buitenwijk Brentwood tegenover de neerwaartse spiraal in dit L.A.. In Brentwood staat L.A. bekend als 'the encroacher', als de opdringerige buurman die voortdurend terrein dreigt te winnen en een inbreuk betekent op de hooggewaardeerde privacy in de wijk. Als stad valt L.A. vanuit Brentwood niet te beheersen, als angstbeeld wel: het wordt angstvallig in stand gehouden. De te grote, chaotische en onveilige stad is voor Brentwoodians een worst case scenario, hun meest onwenselijke tockomst. Koste wat kost willen zij voorkomen dat de wijk net als de metropool downhill gaat. Los Angeles is op weg naar het einde, Brentwood zet de tijd stil.

Het beeld van de buitenwijk waarin rust, orde en stabiliteit worden beschermd tegen de negatieve invloed van de omgeving heeft wortels in een traditie die nauw is verbonden met de Amerikaanse suburbane droom. Al vanaf het begin wordt de ideale buitenwijk in utopische termen neergezet. Voorbij the last frontier wacht een Nieuwe Wereld, komt de hemel op aarde binnen handbereik. Suburbia geldt als een nieuw Eden, belichaamt de aloude hoop op een herwonnen paradijs. ${ }^{206}$ Nog steeds dragen legio boeken en artikelen over de buitenwijk woorden als 'droom', 'morgen' en 'paradijs' in hun titel en worden met name de luxere suburbs opgevoerd als gerealiseerde utopie. Zo typeert René Boomkens de buitenverblijven van de rijken in de heuvels van L.A. bijvoorbeeld als 'private utopia's', gelegen in 'een grenzeloos suburbia dat een hang verraadt naar onbekende droomwerelden'. Het suburbane, volgens sommigen postsuburbane Irvine ten zuidoosten van de stad omschrijft hij als 'een groen paradijs voor autobezitters, een droom van rust en veiligheid' en 'de meest concessieloze en geslaagde variant van het suburbane utopia' (Boomkens(1998): pp. 313, 314).

Noties als 'de hof van Eden' en 'het herwonnen paradijs', betoogt filosoof Hans Achterhuis in De erfenis van de utopie(1998), zijn premoderne voorlopers van de utopie: de goede plaats die nergens bestaat. Daarvan worden er vanaf de zestiende eeuw - vanaf Thomas More's Utopia (1516) - talloze geschreven. Hoewel deze onderling verschil- 
len, vertonen ze sterke familiegelijkenissen, laat Achterhuis zien. Hij spreekt van een utopisch vertoog met een beperkt metaforisch repertoire. Steeds keren dezelfde beelden en wendingen terug en herkennen we eenzelfde logica. In Couplands notebook duikt een aantal van deze gelijkenissen op. Ze vormen belangrijke bestaansvoorwaarden voor zijn portret van de wijk. Brentwood voldoet aan twee belangrijke eisen die Achterhuis aan de utopie stelt. $\mathrm{Ze}$ is maakbaar en vereist een totale verandering, vaak gerealiseerd door een breuk met de situatic - in 'Brentwood Notebook' zowel tijd als plaats - waarin ze wordt geformuleerd. Het niet-bestaande, ideale oord isoleert zich, schermt zich af en streeft naar volledige beheersing van gemeenschap en woonomgeving.

'Brentwood does not exist,'schrijft Coupland. Het wekt de indruk 'a 1970 s future utopia' te zijn. 'Brentwood, like Palm Springs, offers a version of an alternative future that might have occured had certain factors not continued unchecked, futures that daily seem less probable' (Coupland (1997): pp. 147, 148). Coupland presenteert de wijk als een utopisch alternatief, een droom die op 4 augustus 1994 is gerealiseerd. Binnen bepaalde grenzen. Omdat de droom is verwezenlijkt, kijken Brentwoodians niet om. Omkijken heeft in een utopie geen zin. Het verleden is er niet van belang, schrijft Achterhuis. Het wordt zelfs veracht, stelt Krishan Kumar in Utopia and Anti-Utopia in Modern Times (1987) (zie Achterhuis (1998): p. 72 en Kumar (1987): p. 258). Illustratief is de afkeer van het verleden in Aldous Huxley's beroemde Brave New World (1932). 'History is bunk' luidt een van de beginselen in deze toekomstgemeenschap. Tegen het verleden is zelfs een heuse campagne gevoerd - met succes, gezien het onbegrip van bewoners bij het horen van alles wat oud is. ${ }^{207}$ Maar Brentwood negeert niet alleen het verleden, ook de toekomst lijkt onwenselijk. Angst voor verandering houdt de wijk in zijn greep. Perfectie duldt geen verandering. Is ze eenmaal gerealiseerd, dan houdt ontwikkeling immers een bedreiging in. Het streven is behoud van wat is bereikt, een eindtoestand. Stabiliteit, schrijft Kumar, is het hoofddoel in iedere utopie (zie ibid: p. 227). 'Stability,' roept Controller Mustapha Mond bijvoorbeeld keer op keer in Brave New World. 'The primal and ultimate need. Stability' (Huxley (1975): p. 44). Die stabiliteit handhaven is in Brentwood echter niet eenvoudig. Dat de wijk zich terugtrekt uit haar omgeving en zowel verle- 
den als tockomst op afstand tracht te houden, verhindert niet dat ze voortdurend vreest dat het binnen haar grenzen net als in de omgeving bergafwaarts zal gaan. Brentwoodians worden beheerst door de gedachte dat chaos, drukte en criminaliteit elk moment hun rust, ruimte en veiligheid kunnen verstoren. ${ }^{208}$

Er staat wat op het spel in Brentwood. Net als in Brave New World is de wijk in Couplands notebook af: '(...) stable now. People are happy; they get what they want (...). They're well off; they're safe (...); they're blissfully ignorant of passion and old age,' in Mustapha Monds termen (ibid: p. 173). In beide gemeenschappen zijn matericle verlangens volkomen bevredigd. Woonhuizen zijn voorzien van alle denkbare gemakken, de consumptiemogelijkheden zijn enorm en bewoners ogen allen even jong en gezond. Brentwood beschouwt zichzelf volgens Coupland als een seculier nirvana: 'better living through sex, money, fame and infrastructure' (Coupland (1997): p. 148). De wijk is een toonbeeld van maakbaarheid. De Brentwoodians hebben op eigen kracht een bucolische illusie gecreëerd en houden deze kunstmatig in stand. De subtropische beplanting is het resultaat van menskracht en verborgen techniek. Voortuinen liggen er perfect bij en het plaatselijke axioma luidt dat vlinders onbekommerd door de zorgvuldig bijgehouden bomen moeten kunnen fladderen (zie ibid: p. 164). Coupland presenteert Brentwood als een product. De realisatie van idealen is te koop. Een greep uit de advertenties uit onder andere Brentwood News levert banken op, een Cartier- en Mercedesdealer, de Mountain Gate Country Club en vele aanbiedingen van riante huizen. Maar het blijft niet bij een nieuwe auto en een fraai staaltje landschapschirurgie. Coupland voert Brentwood op als 'a living guide to what might be termed a catalogue of the new temptations: instant wealth, emotionally disengaged sex, (...) belief in the ability (...) to alter (...) one's flesh or personality architecture, (...) body manipulation' (ibid: p. 156). Nu het medisch-technisch mogelijk is, veranderen Brentwoodians ook hun eigen lichaam. Niemand kijkt er nog van op als iemand na een plastisch-chirurgische ingreep met pleisters en al in het openbaar verschijnt, schrijft Coupland (zie ibid: p. 152). Wat op macroniveau in de wijk gebeurt, wordt op microniveau in het persoonlijke leven nagestreefd: de Brentwoodian wil voor altijd blijven wat hij of zij is: jongen geslaagd. 
Brentwoods stralende gezicht heeft een keerzijde. Het suburbane ideaal mag dan als utopie zijn verheerlijkt, zoals we in hoofdstuk 3 hebben gezien wordt het vanaf de jaren vijftig steeds vaker in dystopische termen neergezet. In het licht van Achterhuis' studie is dit niet verwonderlijk. Hij spreekt van een fundamentele eenheid van utopie en dystopie: het gaat om dezelfde soort samenlevingen, ze worden alleen vanuit verschillende invalshoeken beschreven. Ook van Brentwood is een andere lezing mogelijk. Het vertoont naast utopische onmiskenbaar dystopische trekken.

Gaat de aandacht uit naar de schaduwkanten van de suburbane droom, dan staat meestal een eigenschap centraal die ook de dystopie kenmerkt: homogeniteit, soms opgevat als zuiverheid. In het eenheidsideaal dient alles aan het geheel te zijn onderworpen. Wat afwijkt, kan niet worden getolereerd, omdat het zich zou onderscheiden en daarmee een bron van vernieuwing zou kunnen zijn, een gevaar dus voor de status-quo. Vaak worden twee consequenties hiervan onderscheiden. Binnen de homogene orde zou het ontbreken aan betekenisvolle sociale verbanden en de 'gemeenschap' als geheel zou streven naar zo min mogelijk contact met buitenstaanders, anderen.

Dat homogeniteit gemankeerde gemeenschappen oplevert, is in de suburbiakritiek een terugkerend thema. Suburbanisatie staat onder meer voor monofunctionaliteit en eenvormigheid. Volgens critici uit verschillende disciplines heeft dit het sociale leven in de buitenwijk geen goed gedaan. $\mathrm{Zij}$ stellen dat de hang naar een gemeenschap van gelijkgezinden paradoxalerwijs resulteert in een gebrek aan een zeker gemeenschapsgevoel. Het zou ontbreken aan betrokkenheid met buurtgenoten en met de ruimte die zij onderling delen. In het publieke domein zou van een openbaar leven nauwelijks meer sprake zijn. In de traditie van onder anderen Richard Sennett betoogt René Boomkens bijvoorbeeld dat de verhouding tussen privé en openbaar dusdanig is verstoord, dat de sociale en gemeenschapsdimensies van het comfortabele wonen verloren zijn gegaan. Daarnaast wijst hij, net als bijvoorbeeld Bret Easton Ellis, op leegte en ervaringsloosheid, met L.A.'s rijke suburbs als toonbeeld. Historicus Kenneth Jackson spreekt in zijn bijdrage aan de 
bundel Suburbia (1976) achtereenvolgens van een 'weakened sense of community', 'of place', 'of belonging', Peter Rowe noemt de meest homogene delen van suburbia in zijn ontwerpgeschiedenis Making a Middle Landscape (1991) 'sociaal destructief' en volgens landschapsarchitect Lodewijk Baljon is de American dream veranderd in Helldorado. ${ }^{209}$ Nog verder gaat Jean Baudrillard. In zijn 'evocatief-filosofische' America (1986) herbergt de utopische droom die tussen Californiê's eucalyptussen en gardenia's is gerealiseerd, een tragedie.

On the aromatic hillsides of Santa Barbara, the villas are all like funeral homes. (...) All dwellings have something of the grave about them, but here the fake serenity is complete. The unspeakable house plants, lurking everywhere like the obsessive fear of death, the picture windows looking like Snow White's glass coffin, (...) the proliferation of technical gadgetry inside the house, beneath it, around it, like drips in an intensive care ward (...), everything here testifies to death having found its ideal home (Baudrillard (1995): pp. 30-1).

Zoals Baudrillards paradijs een soft, airconditioned hell inhoudt, gaat achter Couplands secular nirvana een gemeenschap in crisis schuil (zie Coupland (1997): p. 148). Brentwood kent nauwelijks gezinnen, bewoners voelen zich nauwelijks met elkaar verbonden en hun interesse in het publieke domein beperkt zich tot nimby-gedrag 210 , geînstitutionaliseerd in de Brentwood Park Homeowners Association. Huishoudens worden in Brentwood steeds kleiner, rijker en ouder, schrijft Coupland. Niet gezinnen, maar ambitieuze tweeverdieners, gym freaks, soap opera walk-ons en divorcées zijn kenmerkend. 'Brentwood is not a place where one establishes a dynastic root. It is not a homestead neighborhood. North American suburbs rarely are places where people expect their children to inherit the family Tara' (ibid: p. 149). Van de gezinnen die zich wel in Brentwood vestigen, vallen de meeste uiteen, 'the common end scenario being divorce, atomization, property divestiture and a move onward' (ibid). Illustratief zijn de krantenadvertenties van specialisten op het gebied van echtscheiding, voogdij, bezoekregelingen en boedelscheiding. Brentwood is geen plaats 'where one goes to breed Bradys' (ibid). 
Het verloop in de wijk is groot. Bewoners komen om vervolgens weer snel te vertrekken, wat niet bevorderlijk is voor de vorming van een gemeenschap. Brentwoodians delen dan misschien een geloof in de waarde van grond en veiligheid, voor sociale cohesie is het niet voldoende. De bewoners tonen volgens Coupland jegens buren best eens hun goede wil, maar slechts tot op zekere hoogte, 'after which social atomization sets in' (ibid: p. 158). Het meest verbonden zijn misschien wel de bezoekers van de wekelijkse AA-bijeenkomst. De elfhonderd aanwezigen hebben in elk geval een gemeenschappelijke uitweg gezocht uit het luxe, maar lege leven in de buitenwijk. Om een laatste vergelijking te trekken met Brave New World: 'And if anything should go wrong, (...) if ever, by some unlucky chance, anything unpleasant should somehow happen, (...) there's always soma to give you a holiday from the facts' (Huxley (1975): pp. 173, 185). Voor een illustratie kunnen we terecht bij de foto op pagina 165 van 'Brentwood Notebook', van soma in de vorm van een handvol Prozac-capsules.

Wat over is van een openbaar leven in de wijk wordt zoveel mogelijk geregisseerd door de homeowners association. De vereniging bewaakt niet alleen de waarde van eigendom, ze controleert ook het gedrag van bewoners en het aanzien van de dingen. ${ }^{211} \mathrm{Ze}$ heeft niet alleen succesvol geageerd tegen herindeling van de wijk en de aanleg van wegen - en daarmee tegen potentiële waardedaling van onroerend goed -, maar vaardigt bijvoorbeeld ook richtlijnen uit voor de wijze waarop bewoners het beste hun vuilnisbak kunnen verbergen. Omdat onregelmatigheden afbreuk zouden doen aan het gladgepolijste oppervlak, dient alles immers naadloos in het geheel te worden ingepast.

Wat niet kan of mag worden ingepast, wordt buitengesloten. De tegenstelling tussen 'wij' en 'zij' is een van de centrale beginselen van de dystopie, schrijft Achterhuis. Het leven is er doortrokken van een hang naar zuiverheid, wat maar al te vaak resulteert in pogingen tot zuivering (zie Achterhuis (1998): pp. 78-80). Buitenstaanders - anderen, de Ander - worden geweerd. De grenzen tussen binnen en buiten worden streng bewaakt. In studies van de hedendaagse inrichting van steden en buitenwijken is deze bewaking een veelbe sproken thema. Diverse disciplines, met name de sociologie en culturele geografie, besteden de laatste jaren uitgebreid aandacht aan 
de grenzen rondom upper-en upper-middle-class woonoorden. Deze zouden zich in toenemende mate afsluiten van het publieke leven dat de stad tot stad maakt, van het contact met anderen. De kritiek luidt dat het openbare domein opgedeeld dreigt te raken in verwaarloosde, gevaarlijke gebieden en gebieden die slechts beperkt toegankelijk zijn en buitenproportioneel zwaar zijn beveiligd. Er wordt gesproken van een 'interiorisering' van de stedelijke ruimte, van defensieve planologie en wallification, die een scheiding tussen 'wij' en 'zij' moeten garanderen, zodat ongewenst contact kan worden voorkomen. ${ }^{212}$ "'Right, utopia has arrived. If you aren't part of it, get lost",' verwoordt Baudrillard de onderliggende logica. 'The have-nots will be condemned to oblivion, to abandonment, to disappearance pure and simple. This is "must exit" logic: "poor people must exit"'(Baudrillard (1995): pp.111-2).

Als zodanig opgevoerd, toont Couplands Brentwood een aanmerkelijk minder vriendelijk gezicht. De wijk laat haar tanden zien aan wie niet gewenst is. Bescherming tegen verandering gaat gepaard met het afschermen van alles wat anders is. De wijk die zich in eerste instantie nauwelijks leek uit te laten over wat ze is, blijkt zich duidelijk uit te spreken over wat ze niet is. In het notebook definieert ze zichzelf in termen van wat ze niet wil zijn. Verscheidene vormen van in- en uitsluiting die in het debat over zwaarbewaakte droomwerelden centraal staan, krijgen in dystopisch Brentwood uitdrukking. Coupland benadrukt bijvoorbeeld dat in grote delen van de wijk voetpaden ontbreken. Deze observatie sluit aan bij een belangrijke kritiek op de inrichting van de suburbane woonomgeving, namelijk dat de publieke ruimte nog slechts het domein is van de auto. Als er al trottoirs liggen, dan slechts voor het ruimtelijke effect. De gedachte is dat voetpaden in de buitenwijk worden geassocieerd met mensen die zich geen auto kunnen veroorloven. Slechts immigranten lopen nog, suggereert Baudrillard bijvoorbeeld. Wie loopt, is een bedreiging voor de publieke orde (zie ibid: p. 58 ). In Brentwood, schrijft Coupland, worden trottoirs geassocieerd met zwervers. In gedeelten waar wel voetpaden zijn aangelegd, voegt hij daaraan toe, worden ze slechts gebruikt door Brentwoods enige soorten voetgangers: joggers en mensen die hun hond uitlaten. Zelfs zij zijn slechts mondjesmaat te zien. En mondeling contact is er niet bij: iedereen draagt een Walkman (zie Coupland (1997): pp. 152,174). 
De boodschap is duidelijk: Brentwoodians sluiten zich af. Niet alleen in het publieke domein vermijden zij contact, ook in de eigen woning houden ze zich schuil. In de wijk wordt veel geadverteerd door beveiligingsbedrijven die allerlei systemen aanbieden ter bescherming tegen ongewenste confrontaties met vreemden. Percelen in Brentwood tonen volgens Coupland zonder uitzondering duidelijk van welke beveiligingssystemen ze zijn voorzien. Dat zijn er nogal wat:

Multilayered exclusion devices insulate properties from the outer world; a perimetric fence and gate (often monitored by cameras) encloses thick hedgerow vegetation which in turn enclose dogs which in turn surround the house which is tripwired with magnets, beams, contact points, numeric in put pads and alarms (ibid: p. 193).

Veiligheid is een van de verleidelijkste eigenschappen van Brentwood, stelt Coupland. Hekken, honden en alarmsystemen zijn belangrijk, maar bewoners worden geadviseerd ook zelf alert te zijn. Coupland citeert uit een nieuwsbrief waarin een vereniging van huizenbezitters haar leden informeert over hoe ze zich beter kunnen beschermen. In verband met zogeheten follow-home crimes dienen ze bijvoorbeeld intensief gebruik te maken van hun autospiegels en achteruit de oprit op te rijden. Bovendien worden zij gewaarschuwd dat zogenoemde louvered windows onveilig zijn. Het advies luidt deze vensters voor de zekerheid met superlijm dicht te plakken (zie ibid: p. 193).

In onzichtbaar Brentwood doen slechts de namen van beveiligingsbedrijven hun best om op te vallen. Op de bordjes in tuinen en op hekken staat Westec, Knight, Brinks, Southland Home Protectors en Protection One, om er slechts enkele te noemen. Dit Brentwood is niet voor iedereen bestemd. De gemeenschap die intern uit losse atomen bestaat, houdt tegenover de buitenwereld de rijen zoveel mogelijk gesloten. Tegenover een bedreigend 'zij' ontstaat een defensief 'wij'. Voor wie de bestaande orde in gevaar kan brengen, blijven de toegangspoorten gesloten. Wie in Brentwood in zijn autospiegel op zoek gaat naar vreemden, krijgt slechts zichzelf te zien. 
In voorgaande hoofdstukken kwamen met uiteenlopende suburbane plekken en levensstijlen verschillende temporele oriëntaties tot uitdrukking. Sommige suburbanisanten werden ervan beschuldigd overmatig terug te blikken, toe te geven aan een nostalgisch verlangen naar oudere vormen van gemeenschap. Anderen werd een nerveuze strijd om status verweten, een rücksichtslos ambitieus streven naar groter en groener wonen. Daarnaast troffen we buitenwijkbewoners aan die in hun omgeving niet thuis waren. In het Mt. Judge uit Rabbit, Run (1960) kon Harry Angstrom de druk niet aan, in Couples (1968) leidden Tarbox' paren een benauwend cyclisch bestaan en in Generation X vluchtten Andy, Dag en Claire naar Palm Springs in een poging om na tegenslagen en teleurstellingen vorm te geven aan een nieuwe toekomst. Aan dit gevaricerde palet voegt 'Brentwood Notebook' een schakering toe. In een tijd waarin Amerika postsuburbaan is verklaard, wordt in het notebook een portret geschetst van een hedendaagse suburb. De boodschap is dat in of rond exopolis L.A. het suburbane ideaal nog springlevend is, maar dat de droom niet meer als vanzelfsprekend kan worden gerealiseerd. Brentwood wordt opgevoerd als een in zichzelf gekeerde, op zichzelf gerichte buurt, slechts geïnteresseerd in behoud van wat is bereikt. Brentwoodians zijn betrokken op verleden noch toekomst: zij verkeren in een eeuwig heden. Stilstand is hun ideaal. Omdat zij geen vooruitgangsverwachtingen meer koesteren, maar vooral bang zijn voor verval, krijgt stilstaan bovendien een nieuwe betekenis. Hield het in bijvoorbeeld Rabbit, Run tegen een achtergrond van hooggespannen verwachtingen per saldo achteruitgang in - zodat we Harry's spiraal als een neerwaartse spiraal konden opvatten -, in Couplands Brentwood is stilstaan het hoogst haalbare.

Leven in een dergelijk heden is in verschillende disciplines opgevat als het toppunt van hedonisme. Een eenzijdige gerichtheid op onmiddellijke bevrediging van de eigen verlangens wordt beschouwd als een asociale en op lange termijn bovendien onhoudbare levensstijl. Het narcistische bestaan dat Christopher Lasch bijvoorbeeld in zijn cultuurkritiek The Culture of Narcissism (1978) opvoert, stemt in veel opzichten overeen met dat in Couplands Brentwood. Het is een leven dat 'grandiose illusions' paart aan 'inner emptiness' (Lasch 
(1979): p. 374). Er goed uitzien is van levensbelang, ouder worden is taboe, achterhaald. De narcist wil niet zozeer gerespecteerd worden, als wel benijd. Wat telt is niet wat hij doet, maar of hij 'het gemaakt heeft'. Daarvoor wordt een prijs betaald, onder andere in de vorm van een ontwricht sociaal leven en gezinsproblematiek, zoals ook in Brentwood huwelijken op de klippen lopen en de buurt meer weg heeft van een belangenvereniging dan van een gemeenschap. Een van de belangrijkste symptomen is bovendien wat Lasch 'historische discontinuïteit' noemt, een gebrek aan banden met verleden en toekomst. Het verleden wordt verwaarloosd. De narcist hecht er geen waarde aan, negeert het. De toekomst legt het af tegen het belang van onmiddellijke bevrediging van verlangens (zie ibid: pp. 25, 101-2, 116-7, 321, 351-3). Beide vormen van desinteresse zijn in Lasch' optiek keerzijden van dezelfde medaille: 'A denial of the past (...) proves (...) to embody the despair of a society that cannot face the future'(ibid: p. 26).

Zoals we in hoofdstuk 3 zagen, hangen verwijten van hedonisme traditioneel samen met een bepaalde opvatting over consumptie. De tijd van consumptie is de vrije tijd, gesteld tegenover werktijd, en consumeren is passief genieten, het tegenovergestelde van actief scheppen, maken, investeren. In een bijdrage aan Steve Pile en Nigel Thrifts cultuurgeografische Mapping the Subject (1995) stelt Paul Rodaway bijvoorbeeld dat de consument uit hapklare brokken reclame en producten een identiteit samenstelt die met persoonlijke en sociale ervaringen niet veel meer te maken heeft. Hij is overgeleverd aan de snelle veranderingen in de modecyclus, waardoor een 'cumulatieve identiteit' niet meer tot de mogelijkheden behoort (zie Rodaway (1995): p. 265), zoals ook Brentwoods hedonisme ten koste gaat van coherentie en continuilteit in het persoonlijke leven. Filosoof Lieven de Cauter noemt de vrije tijd van consumptie in Archeologie van de Kick (1995) 'een lege tijd, een tijd die bestaat uit "numomenten"; het is een actuele tijd, zonder voortgang, zonder doel' (De Cauter (1995): p. 133). Samen met het passieve karakter van consumeren leidt deze tijd volgens De Cauter onontkoombaar tot verveling, zoals ze ook in Brentwood leegte oplevert, 'a certain blankness in the eyes (...), personal history and narrative cashed in like frequent flyer points on vacations that failed to amuse within a frighteningly short period of time'(Coupland (1997): p. 185). ${ }^{213}$ 
Deze intense, maar eenzijdige betrokkenheid op het heden komt in Couplands notebook tot uitdrukking in een buurt waarin weinig wordt gesproken, maar des te meer wordt gekeken. In Brentwood heerst de blik. Bewoners genieten van het prachtige groen en van elkaars aantrekkelijke jonge lijven. Ze verlangen primair naar mooie buitenkanten. In hun wijk is identiteit vooral een kwestie van flinterdunne oppervlakken. In het notebook verschijnt Brentwood als een zeepbel: schitterend, leeg en kwetsbaar. Het tracht zichzelf zo lang mogelijk in stand te houden, maar of het daarin ook na 4 augustus 1994 nog lang zal slagen, is zeer de vraag. De bel, de droom, dreigt in de turbulente grootstedelijke omgeving elk moment uiteen te spatten.

Coupland suggereert dat het in Brentwood altijd 4 augustus 1994 moet blijven. Dat is een bijzondere datum: het is op die dag precies tweeěndertig jaar geleden dat Marilyn Monroe in Brentwood stierf. Brentwoods eindtoestand lijkt naar haar dood te zijn gemodelleerd. Net als Monroe lijkt de wijk de tijd vaarwel te zeggen op het hoogtepunt van haar carrière. Door het tijdelijke voor het eeuwige te verwisselen, hoopt ze de schijn van perfectie intact te kunnen houden. De vraag is of ze in haar opzet slaagt.

Monroe stierf volgens Coupland juist na afloop van wat fotografen het 'magische uur' noemen, net nadat de gouden gloed waarin alles vitaal lijkt, was verdwenen (zie ibid: p. 197). Is ook Brentwood niet te laat? Aan het eind van haar leven zag Monroe geen toekomst meer voor zich, stelt Coupland. Door een overdosis roem-Post Fame in Couplands termen - 'she had been denarrated and there seemed no other possible narrative arc to her life. (...) In the end she was trying too hard to put a pleasant facade onto - nothingness' (ibid: p. 184). Op enkele van de laatste foto's 'her skull began to show through more clearly. She began to resemble someone other than the self that had been manufactured, an actual person. Her body (...) was on the brink of erosion' (ibid: p. 191). Twee foto's van Marilyns gezicht op pagina 183 van het notebook illustreren dit. De ene toont kraaienpootjes rond haar ogen, de andere haar holle blik. Lichaam en geest lijken hun beste tijd te hebben gehad. Er lijkt verval te zijn ingetreden. Het masker vertoont scheurtjes en kan de achterliggende leegte niet langer verhullen. Wat is de uiterste houdbaarheidsdatum van Brentwoods perfectie? 4 augustus 1994? De ogenschijnlijk 
stabiele orde is kwetsbaar. Brentwood moet zich tegen tal van bedreigende omstandigheden beschermen. De landelijke illusie bestaat slechts bij de gratie van moderne technologie en de ontkenning ervan, afval verdwijnt in de verborgen vuilnisbak. De wijk bestrijdt het afwijkende binnen haar grenzen, houdt nieuwsgierigen zoveel mogelijk op afstand, wapent zich tegen stedelijk verval en ontzegt de ongewenste Ander de toegang. Zo ontkent ze de condities waaronder het ideaal tot stand is gebracht met alle geweld. Bovendien - en hiermee toont Brentwood zijn laatste, best verborgen gezicht - ontkent het dit geweld. Het ligt in het hart van de wijk verborgen.

'Brentwood is a suburb of indeterminate verdicts and unclear death,' stelt Coupland (ibid: p. 186). 'Murders aren't solved here. Monroe; Brown Simpson (...) - their investigations simply drag on until amnesia sedates any enthusiasm for a full solution' (ibid). Het ideale leven in de wijk is van binnenuit aangetast. 'Brentwood's mood is noir (...). With a hindsight look at Brentwood, it seems inevitable that what happened did happen, if not with O.J. then with some other cataclysm reconfigured'(ibid: pp. 160, 197). Met Achterhuis kunnen we concluderen dat het onder het gladgepolijste deksel van deze utopische hogedrukpan kookt en borrelt. Achter een façade van comfort gaan spanningen schuil en tegen wie het deksel licht, wordt hard opgetreden. Tegen buitenstaanders vrij openlijk, naar binnen toe in bedekte vorm. Om het fragiele evenwicht in Brentwood te beschermen, worden aan bewoners hoge eisen gesteld. Naast de waarschuwingen, richtlijnen en bindende adviezen van de homeowners association leggen vooral ongeschreven regels de gemeenschap aan banden. Wie deze overtreedt, wie bijvoorbeeld net als 0 .J. Simpson om persoonlijke redenen het collectieve imago in gevaar brengt, wordt verstoten.

Verbannen worden is de grote angst van de publieke mens, schrijft Sarah Benton in de bundel Citizens and Responsibilities (1991). Hij wordt erdoor in toom gehouden. In het openbare leven zijn burgers als lid van een gemeenschap verantwoording schuldig. In het publieke domein zijn zij kwetsbaar, doordat wie een fout maakt uitsluiting uit eigen kring riskeert. De enige plek waar men zich kan overgeven aan excessen is de eigen woning. Wat daar plaatsvindt, is immers onzichtbaar. Wat zich binnen Brentwoods riante 
villa's afspeelt, blijft voor buurtgenoten en televisiestations verborgen. Het eigen perceel is de enige plaats in de wijk waar instabiliteit, onrust en chaos kunnen worden gedoogd. Ze zijn daardoor in Brentwood tegelijkertijd aan- $e n$ afwezig. Hetzelfde geldt voor het geweld in de wijk. In het privé-domein, de binnenste cirkel van beveiligd Brentwood, wordt het opgeborgen. Marilyn Monroe vond de dood in haar eigen huis in Brentwood. De Simpson-moorden hadden binnensmuurs plaats. Helaas konden noch de hekken, noch de dichtgelijmde ramen voorkomen dat openbaar werd wat verborgen had moeten blijven. Het geweld van binnen kwam naar buiten. De chaos en de aandacht die buiten hadden moeten blijven, kwamen naar binnen. Onzichtbaar Brentwood werd zichtbaar. Het bestaat, want het staat op de kaart. 


\section{Brentwood als construct}

Als lezer van Couplands notebook kun je maar beter op je hoede zij. Wie een antwoord verlangt op de vraag hoe Brentwood er werkelk uitziet of hoe het leven er feitelijk wordt geleefd, kan het stuk berr ongelezen laten. Nadrukkelijker dan welke tekst ook die tot nu te in dit proefschrift de revue is gepasseerd, maakt 'Brentwood Norbook' duidelijk wat er al niet in het werk wordt gesteld om en enkele buitenwjik te verheelden. Zaals in ellectunls . 3nsue wonod verbeeld het resultaat van hoe het portret in elkaar steekt. Bijzonder is dat het notebook dit niet verhult. Het laat duidelijk zien dat het een construct is. Niet alleen wat wordt verbeeld - de complexe relatie tussen de inrichting van deze suburb, de problematische identiteit en de wanhopige temporele oriëntatie van haar bewoners -, ook wat daarvoor in het stuk moet gebeuren, vraagt de aandacht. Er wordt een spel gespeeld met het werkelijkheidsgehalte van Brentwood en het weefsel van vertellingen dat de wijk maakt tot wat ze is, laat duidelijk zijn rafelranden zien.

In de bundel waarvan het notebook deel uitmaakt, onderzoekt Coupland naar eigen zeggen hoe het in de eerste helft van de jaren negentig is gesteld met de Amerikaanse samenleving. In dat kader is Brentwood niet zomaar een buitenwijk. De buurt belichaamt problemen op grotere schaal:

Brentwood's is a landscape where too many unraveling and overpowering factors collide; it is a municipal and psychic bevatron, a smashing together of fame and paranoia and desire and bodies and money and power, and race and denial and media overload and all of the machinery of late-twentieth-century living (Coupland (1997): p. 197). 
Brentwood wijst als het ware voorbij zichzelf en als zodanig vervult het de rol van een exemplarische wijk aan de Amerikaanse westkust aan het eind van de twintigste ecuw. Exemplarische wijken worden in het suburbiaonderzoek vaker ingezet om een algemener beeld concreet te maken. ${ }^{214}$ De bekendste voorbeelden zijn Riverside, Forest Hills Gardens, Levittown en Irvine. In vrijwel elke studie van suburbia belichamen zij, in verschillende perioden van de geschiedenis, het suburbane ideaal of schrikbeeld. Als zodanig vervullen ze impliciet een dubbeirol. Niet alleen brengen ze in de tekst de suburbane droom of nachtmerrie tot leven, ze gelden bovendien als plaatsen waar deze zijn verwezenlijkt, werkelijkheid zijn geworden. Deze dubbelrol wordt normaliter niet geproblematiseerd. Riverside, bijvoorbeeld, wordt in Fishmans Bourgeois Utopias (1987) opgevoerd als de belichaming van de utopie, in Sterns Pride of Place (1986) als 'the essential fantasy of the suburban ideal' en 'a dream town come true' en in Kunstlers The Geography of Nowhere (1993) als het prototype van 'the dream of an achieved arcadia' (zie Fishman (1987): p. 132; Stern (1986): p. 135; Kunstler (1994): p. 56). In Couplands notebook, daarentegen, wordt de spanning tussen Brentwood als ideaal en als werkelijke buitenwijk van L.A. expliciet gethematiseerd. Het is een belangrijk kenmerk van dit bijzondere portret van de suburb.

Dat Brentwood bestaat, is in het notebook geen gegeven, zoals het ook niet vooraf vaststaat of de wijk een droom of nachtmerrie is. Brentwood is in Couplands stuk geen werkelijke buitenwijk van L.A. en is geen ideaal of schrikbeeld, maar wordt nadrukkelijk als zodanig voorgesteld. De wijk is een intrigerend effect van een voortdurende wisseling van perspectieven. Hoewel het niet op de kaart staat, suggereert Coupland dat we Brentwood net als hijzelf zouden kunnen bezoeken. Hij presenteert zijn notebook immers als een verslag, wat de suggestie wekt dat hij er is geweest en er het een en ander heeft gezien. In die zin bestaat Brentwood, als werkelijke buitenwijk van L.A.. Tegelijkertijd wordt het werkelijkheidsgehalte van de wijk op verschillende manieren in twijfel getrokken. Omdat ze niet autonoom is, bestaat ze formeel niet en bewoners kunnen volgens Coupland nauwelijks aangeven waar hun buurt begint en eindigt. Daarnaast wordt Brentwood opgevoerd als een wijk die er alles aan doet om als transparant onderdeel in haar omgeving te verdwijnen, die richtlijnen uitvaardigt voor wat zichtbaar mag zijn 
en wat verborgen dient te blijven en waar geweld tegelijk aan- en afwezig kan zijn. ${ }^{215}$

Als droom is Brentwood wel en niet uitgekomen. Het utopische ideaal dat binnen bewaakte grenzen is verwezenlijkt, is een 'alternative future that might have occured had certain factors not continued unchecked' (Coupland (1997): p. 148, cursivering DH). Als dystopie, tot slot, geldt Brentwood als een nachtmerrie die aan de Amerikaanse westkust realiteit is geworden en die bovendien als doemscenario in toenemende mate ook andere delen van de westerse wereld in zijn greep houdt. De gedachte luidt dat wat hier reeds is gerealiseerd elders ook wel eens werkelijkheid zou kunnen worden. Zo beschouwt Europa de westkust volgens Coupland als waarschuwing. De nieuwe wereld toont de oude waartoe bepaalde ontwikkelingen kunnen leiden. 'The cautionary tales of Brentwood (...) offer examples, and possibly advice' (ibid: pp. 180-2).

Typeringen van een enkele buitenwijk zijn in het notebook vervlochten met karakteriseringen van een samenleving en cultuur in het algemeen. Afwisselend wordt in- en uitgezoomd. Nu eens vormen details in Brentwood een onderwerp op zich, dan weer zijn ze een exemplarische uitdrukking van een materialistisch en hedonistisch bestaan. Uiteenlopende thema's worden hiertoe met elkaar in verband gebracht, van de zorgvuldige inrichting van de wijk en de vrees voor sprawling L.A. tot de uit de hand gelopen roem van Marilyn Monroe en de kwestie O.J. Simpson. Coupland wijdt hieraan eigen observaties en overwegingen, maar ontleent daarnaast veel informatie aan de meest uiteenlopende bronnen. Hij verzamelt advertenties uit de lokale krant Brentwood News en citeert artikelen uit The New York Times en Los Angeles Times, put even gemakkelijk uit diverse (foto)archieven als uit briefjes op het mededelingenbord in de supermarkt en haalt stukken aan uit populaire tijdschriften als Sports Illustrated, People, Tv Guide, Makeover en Hellol, maar ook Psychology Today, The Economist, Sunday Times's Culture en The New York Times Magazine. Deze worden bovendien nog in verband gebracht met passages uit memoires, een biografie van Dean Martin, Nathaneal Wests roman The Day of the Locust, Mike Davis' L.A.-studie City of Quartzen de menukaart van een lokaal eethuis.

'Brentwood Notebook' is een construct, een aaneenschakeling van korte passages, onderbroken door witregels en sterretjes. Het 
stuk vormt geen lopend geheel, maar vestigt met zijn abrupte overgangen tussen onderdelen juist de aandacht op zijn eclectische karakter. Passages onderscheiden zich doordat lopende tekst wordt afgewisseld door opsommingen en foto's, door verschillen in lettertypen en -grootten, vetgedrukte titels en kopjes in kapitalen. Bovendien zijn sommige passages cursief gedrukt en andere omkaderd en zijn stukken tekst nu eens gecentreerd, dan weer uitgelijnd. 'Brentwood Notebook' is geen naadloos weefsel, maar een bonte lappendeken waarvan de naden zichtbaar blijven.

De titel van het stuk geeft in dit opzicht een belangrijk signaal af: het notebook is een aantekeningenschrift. Schetsen vormen daarin een geheel in wording, een geheel dat nog geen eenheid is. 'Brentwood Notebook' toont als het ware nog een deel van de arbeid die moet worden verricht, wil een portret van een buitenwijk overtuigen. Het helpt ons gevoeliger te worden voor de wijzen waarop suburbs en hun bewoners in een tekst gestalte krijgen. 


\section{Een portret op}

\section{het kruispunt van genres}

Een laatste eigenschap waarmee het notebook onze zinnen schpt, hangt met dit heterogene karakter nauw samen. Het stuk laatich niet eenvoudig rekenen tot de sociaal- of geesteswetenschappejke dan wel de literaire traditie. Al eerder waren teksten aan de orddie genregrenzen overschrijden. Zo kunnen we Keats' The Crack ithe Picture Window (1956) lezen als een roman, maar dan wel één wirin alleriei experts de hoofdvertelling onderbreken en de personages nauwelijks meer zijn dan schietschijven voor de auteur. En zo maakt de raamvertelling in Couplands Generation X (1991) deel uit van een literaire traditie, maar kennen we het margelexicon en de appendix met statistieken eerder uit handboeken en sociaal-wetenschappelijke studies. Zijn deze verschillende onderdelen in Generation $\mathrm{X}$ echter nog gemakkelijk te onderscheiden, in het weefsel van 'Brentwood Notebook' zijn de verschillende draden nauwelijks meer te ontwarren. ${ }^{216}$

Het notebook is een tekst op het kruispunt van genres. Het ontleent elementen aan de culturele geografie, journalistiek en literatuur, maar valt tot geen ervan te reduceren. Als onderzoek naar wat Brentwood Brentwood makt en bovendien naar wat deze ene buitenwijk ons kan leren over algemener fenomenen en ontwikkelingen is Couplands notebook vooral verwant aan studies van suburbs in de culturele geografie. Daarin wordt het suburbane, met name upper-middle-class landschap vrijwel zonder uitzondering beschouwd als uitdrukking van sociaal-economische verhoudingen. Als symbool dragen de inrichting van wijken, de grootte en stijl van woningen en het aangelegde landschap status uit, als onderdelen van de materiêle omgeving helpen ze verschillende groepen in- dan wel uitsluiten. De suburb vormt zo in de meeste artikelen en boeken uit deze discipline een morele en politieke woonomgeving. In een reeks publicaties van James en Nancy Duncan, bijvoorbeeld, zijn 
velden en, zoals in 'Brentwood Notebook', vooral bomen veel meer dan aantrekkelijke landschappelijke elementen. Ze tonen de 'goede smaak' van de gemeenschap, maken bouwgrond schaarser en houden huizenprijzen hoog, waardoor ze de toegankelijkheid van de buurt effectief beperken. ${ }^{217}$ Als kritische lezing van Brentwoods gebouwde omgeving is het notebook echter veel minder systematisch opgebouwd dan studies als deze. Hoewel de Duncans in hun artikel 'The Aestheticization of the Politics of Landscape Preservation' (2001) bijvoorbeeld net als Coupland naast het landschap zelf geschiedenissen, beleidsteksten, advertenties en krantenartikelen opvoeren, smeden zij deze fragmenten in cen lopend betoog tot een cenheid. Eerder dan systematische analyse organiseert fascinatie het notebook. Stellingen worden niet verdedigd door een stapsgewijze argumentatie en in plaats van heldere conclusies treffen we metaforische en soms ronduit cryptische suggesties aan - veelal scherpe typeringen, maar zelden eenduidig.

'Brentwood Notebook' is essayistischer van opzet. Wat betreft de soepele verteltrant en virtuoze retoriek is het verwant aan James Kunstlers The Geography of Nowhere. Beide stukken paren gedetailleerde observatie aan sweeping statements en in beide drukt het grote gebaar betrokkenheid uit, niet alleen met de gebouwde omgeving, maar ook met de samenleving en cultuur waarvan ze het resultaat is. Waar Kunstler zich echter persoonlijk betrokken toont - door bijvoorbeeld de ikvorm te gebruiken en zijn eigen verleden in het betoog te betrekken -, houdt Coupland afstand. Hoewel hijzelf duidelijk de bezoeker en verteller is, wekt hij de suggestie dat Brentwood voor zich spreekt. De wijk is in de meeste zinnen het onderwerp. Ze wordt soms afgewisseld door een algemeen 'men' of niet nader gespecificeerd 'wij', maar zichzelf voert Coupland niet op. In tegenstelling tot in Kunstlers betoog - en bijvoorbeeld ook in het door Coupland geciteerde City of Quartz - slaat zijn fascinatie daardoor niet om in verontwaardiging, woede of cynisme. Coupland ridiculiseert en verkettert niet. Hoewel luxe in zijn notebook leegte oplevert en hij in Brentwoods verlangen naar stabiliteit vooral een angstige en krampachtige levenshouding ziet, is zijn toon eerder verwonderd dan beschuldigend.

Objectief is Couplands stuk niet. Hij mag zichzelf dan op de achtergrond plaatsen, in zowel thematiek als vocabulaire is hij nadruk- 
kelijk aanwezig. We herkennen veel van de interessen uit zijn romans, verhalen en essays en zoals zijn beste werk drukt het notebook feilloos de tijdgeest uit. Met zijn interesse in actuele, vooral wereldlijke cultuur staat het in de traditie van het New Journalism dat in het Amerika van de jaren zestig en zeventig furore maakte. Het houdt het midden tussen de journalistieke reportage en het achtergrondverhaal, maar wel uitdrukkelijk met Couplands signatuur. Hij leidt de lezer door Brentwood, hij selecteert, ordent en interpreteert de achtergrondinformatie die hij heeft verzameld en hij associeert fragmenten daaruit met observaties in de wijk. Bovendien valt op dat vrijwel niemand uit de wijk aan het woord komt. In het notebook is Brentwood eerder zijn Brentwood dan dat van Brentwoodians.

Een derde traditie waarin we 'Brentwood Notebook' kunnen be grijpen, is de literaire. Het stuk is niet thematisch opgebouwd, zoals op grond van zijn sociaal-wetenschappelijke en journalistieke karakter zou kunnen worden verwacht. Vijf dagdelen vormen de vertelstructuur. Van de ochtend tot de nacht zien we verscheidene bewoners aan ons voorbijtrekken, uitgelicht tegen een decor van onder meer planten en bomen, hekken en camera's, fitnessclubs en een begraafplaats. De sfeer die gedurende deze dag wordt opgeroepen, is ambigu - een eigenschap die in de literatuur, in tegenstelling tot het wetenschappelijke betoog en de journalistieke reportage, doorgaans van groot belang wordt geacht. Brentwood is comfortabel, maar er worden lege levens geleid. Het bestaan is er verleidelijk, maar stoot tegelijkertijd af, omdat over deze schitterende omgeving een schaduw ligt. De wijk wil doen geloven dat er niets aan de hand is, maar slaagt er niet in onderliggende onrust, angst en geweld voor altijd aan het gezicht te onttrekken.

Deze sfeer wordt op verschillende wijzen neergezet. In Brentwood is groen bijvoorbeeld niet alleen de kleur van het luxe, landelijke wonen, maar ook van de dood. Niet alleen eucalyptussen, tennisbanen en Jeeps, ook de jurk en de sjaal van de begraven Marilyn Monroe zijn groen. Bovendien garanderen bomen en planten Brentwoods bucolische imago niet alleen door transformatorhuisjes te maskeren, ze worden ook ingezet om de plaats waar Nicole Brown Simpson en Ronald Lyle Goldman zijn vermoord, aan het gezicht te onttrekken. Ze kleuren goed bij het groene hek dat die 
plek afschermt. Gaandeweg raakt de kleur groen besmet: door de associatie met de dood draagt ze in het notebook bij aan suspense.

Ook de vertelstructuur zorgt voor een oplopende spanning. In Brentwood wordt het letterlijk en figuurlijk langzaam donker. Als de dag op zijn eind loopt, nadert de dood van Monroe. Doordat haar laatste uren hun schaduw werpen over dezelfde vierde augustus zoveel jaar later, kent 'Brentwood Notebook' een spanningsboog die in literaire verhalen en romans over suburbia eerder regel dan uitzondering is. Ogenschijnlijk kalme en ordelijke suburbs gaan veelvuldig gebukt onder een naderend onheil. Soms voltrekken rampen zich onverwacht, maar in de meeste verhalen lijken ze onafwendbaar. Van meet af aan is het in perfect suburbia niet pluis. Het is een kwestie van tijd voor het misgaat.

Er zijn voorbeelden te over. In Richard Yates' Revolutionary Road (1961) stelt de verteller dat het pastelkleurige Revolutionary Hill Estates 'had not been designed to accomodate a tragedy. (...) A man running down these streets in desperate grief was indecently out of place'. Toch is de suburb al voordat de Wheelers er komen wonen naast 'invincibly cheerful' 'perfectly dreadful'. Zelfs 's nachts mag het licht er sprookjesachtig zijn en mogen het gelach, het applaus en de strijkorkestjes op televisie zorgen voor muzikale begeleiding, van meet af aan is duidelijk dat het in 'toyland' dramatisch fout zal gaan (zie Yates (2001): pp. 29, 323). De spanning zit er ook in John Cheevers Bullet Park (1967) al snel goed in. Het lot van verscheidene bewoners doet de naam van de suburb eer aan. $\mathrm{Al}$ in het eerste hoofdstuk schiet iemand zichzelf in zijn eigen tuin dood en overlijdt een ander doordat hij tijdens een barbecue party aan Redburn Circle vlam vat. De sfeer wordt gaandeweg grimmiger. Een forens wordt onder een trein gezogen, een hulpeloze schildpad wordt met grof geweld afgemaakt en een van de hoofdpersonages probeert een willekeurig slachtoffer in de kerk op het altaar in brand te steken. Om uiteindelijk alles even 'wonderful, wonderful, wonderful, wonderful' te vinden als altijd is een flinke dosis medicijnen onontbeerlijk. In Jeffrey Eugenides' The Virgin Suicides (1993)en Alice Hoffmans Local Girls (1999) voltrekt het noodlot zich stiller. De vijf zusjes in Eugenides' roman beroven zich in de beslotenheid van hun eigen huis van het leven. Iedereen ziet het aankomen, maar niemand kan er iets aan doen. In Hoffmans roman wordt het noodlottige decor 
gevormd door het ingetogen Franconia, 'the suburb where we were doomed to live,' aldus hoofdpersonage Gretel Samuelson (Hoffman (2000): p. 31). Er worden niet alleen zelfmoorden gepleegd, de dood ligt er ook in de vorm van drugsverslaving op de loer. ${ }^{218}$

Ondanks de 'literaire' spanningsboog die 'Brentwood Notebook' deelt met romans als deze, vertelt het stuk geen verhaal. In de verzameling fragmenten zouden we hooguit de rode draad van momenten uit Monroe's laatste dag een verhaal kunnen noemen. De rest van het stuk is een aaneenschakeling van geïsoleerde momenten uit Brentwoods geschiedenis, observaties, achtergronden, citaten, stellingen en overwegingen. ${ }^{219}$ Wat hierdoor ontbreekt, wordt duidelijk als we het notebook vergelijken met twee romans waarin over suburbane in- en uitsluiting, angst voor verandering en geweld wel een verhaal wordt verteld: Gloria Naylors Linden Hills (1985) en T. Coraghessan Boyle's The Tortilla Curtain (1995). Linden Hills verhaalt van een suburb die in veel opzichten een zwart, African American evenbeeld is van Couplands Brentwood. Wie woont in Linden Hills heeft het gemaakt en beschermt wat is bereikt zoveel mogelijk tegen invloeden van buitenaf. Hoewel net als in Brentwood niemand kan aangeven wat de precieze grenzen van de wijk zijn, worden deze angstvallig bewaakt, zowel tegen de uitbreiding van een nabijgelegen arme wijk als tegen zwervers. Bovendien betalen de inwoners van Linden Hills net als Brentwoodians voor hun luxe en veilige bestaan een hoge prijs. Onder het schitterende oppervlak gaat leegte schuil en ook in deze wijk heerst de dood. Bewoners plegen zelfmoord of komen onder bizarre omstandigheden om het leven. Het geweld dat ook hier angstvallig wordt opgeborgen, komt uiteindelijk onvermijdelijk tot uitbarsting.

Net als in 'Brentwood Notebook' staan persoonlijke tragedies model voor het onheil in de wijk als geheel. Een groot verschil is dat in Linden Hills het perspectief niet alleen bij de buitenstaander ligt, maar ook bij inwoners zelf. ${ }^{220}$ Kijken we met hen mee, dan blijken verschillende bewoners om verschillende redenen met elkaar op gespannen voet te staan. Brentwood is noir, in de schaduw over Linden Hills worden verschillende tinten uitgelicht die suburbane levens op uiteenlopende wijzen kleuren.

Ook in Boyle's The Tortilla Curtain hebben inwoners van een welvarende suburb verschillende, soms tegenstrijdige belangen. Belang- 
rijker voor de vergelijking met 'Brentwood Notebook' is echter dat de buitenstaander in deze roman niet een bezoeker is die een dagje komt kijken, maar de buitengeslotene - illegale Mexicaanse immigranten in dit geval. Afwisselend krijgen we het chique Arroyo Blanco Estates in de heuvels buiten L.A. te zien door de ogen van inwoners en de door hen gevreesde arme immigranten. Met elke perspectiefwisseling verandert de wereld radicaal. Kijken we bijvoorbeeld met de rijke makelaarster Kyra mee, dan zijn Mexicanen bedreigende, gezichtsloze gedaanten aan de randen van ons blikveld. Zien we de wereld door de ogen van de arme Cándido, dan vormen buitenwijkbewoners de bedreiging, omdat ze met hun grote auto's immigranten aanrijden en hen kunnen aangeven bij de vreemdelingendienst. Tegelijkertijd bieden zij echter de kans op een beter bestaan, omdat alleen zij voor goedkope arbeidskrachten klusjes hebben, zoals het bouwen van hekken en muren. Naast het luxe, maar angstige leven in de buitenwijk is het vooral dit paradoxale bestaan van immigranten als Cándido dat in Boyle's roman tot leven komt. Het verhaal neemt de lezer mee in de doffe ellende van de illegale Mexicaan en maakt pijnlijk duidelijk hoe armoe en uitzichtloosheid ervoor zorgen dat hij hoopt te mogen bouwen aan de muur die hem buitensluit.

Waar The Tortilla Curtain de lezer mogelijkheden biedt verschillende standpunten in te nemen, houdt Coupland afstand. Hoewel 'Brentwood Notebook' eigenschappen deelt met romans als die van Boyle en Naylor, brengt het geen identificatieproces op gang. Naarmate het donkerder wordt, wordt de ambigue sfeer in de wijk dreigender, maar doordat het notebook geen verhaal vertelt en geen personages opvoert, blijft die dreiging abstract. Couplands stuk wekt verwachtingen om deze vervolgens doelbewust niet waar te maken. Op geraffineerde wijze speelt het met conventies uit literatuur, journalistiek en geografie. Tot op zekere hoogte houdt het zich aan de regels die in verschillende genres impliciet gelden. Tegelijkertijd lapt het die aan zijn laars en speelt het afspraken uit verschillende disciplines tegen elkaar uit. Zo confronteert het notebook ons als lezer met wat we nu precies verwachten van diverse soorten teksten en met wat deze doen om ons op een bepaalde manier voor zich te winnen. 


\section{Conclusie}

In een zogenoemde postsuburbane tijd onderscheidt 'Brentvood Notebook' in megalopolis L.A. een fascinerend suburbaan eilandje. Couplands Brentwood is, in termen van hoofdstukken 4 en 5 , een chronotoop die in verscheidene gedaanten zowel plaats, tijc als identiteit problematiseert. Het is een in zichzelf gekeerde non-place die geobsedeerd haar grenzen bewaakt - tegen groeiend, chaotisch en onvoorspelbaar L.A., tegen aandacht van de media en in hun kielzog van nieuwsgierige buitenstaanders en vooral tegen de onderbedeelde Ander. De wijk beschermt een luxe, maar leeg leven, in een gemeenschap die slechts in het defensief de gelederen weet te sluiten. Wat in Brentwood is bereikt, laat veel te wensen over. In een turbulente omgeving willen stilstaan, eist zijn tol.

De vraag of Couplands notebook deze buitenwijk al dan niet accuraat weergeeft, is niet zinvol. Die naar de wijze waarop ze precies totstandkomt des te meer. Het stuk wekt de indruk een verslag te zijn van een bezoek aan de wijk, maar mobiliseert veel meer dan slechts observaties ter plaatse. Met behulp van klassieke vertellingen over suburbia wordt Brentwood neergezet als een ideale, zowel utopische als dystopische buitenwijk. Op diverse wijzen wordt in twijfel getrokken of de wijk wel bestaat, en zo ja, of op deze afgegrensde plek, in dit geïsoleerde heden nu een droom of juist een nachtmerrie werkelijkheid is geworden. Coupland haalt voor dit portret veel overhoop. Hij put uit archieven, verzamelt advertenties en citeert uit kranten, tijdschriften, memoires, een roman en een sociaal-wetenschappelijke studie. Doordat hij deze uiteenlopende passages bovendien niet tot een naadloos geheel smeedt, blijft zichtbaar hoeveel werk er wordt verzet voor een portret van een enkele buitenwijk.

De arbeid die wordt verricht, plaatst het stuk tot slot op het kruispunt van genres. Het hoort thuis in journalistiek, culturele 
geografie noch literatuur, maar ontleent aan alledrie strategieèn. Verschillende genreconventies worden binnengehaald en tegen elkaar uitgespeeld. Dat is verwarrend, omdat het ons verwachtingspatroon verstoort. Als hybride wekt 'Brentwood Notebook' indrukken die doorgaans worden toegeschreven aan verschillende soorten teksten, zoals bijvoorbeeld de zakelijke, persuasieve en artistieke die J.J.A. Mooij in Idee en Verbeelding (1981) onderscheidt. Als journalisticke reportage registreert het, wekt het de indruk een betrouwbare overdracht van feiten te zijn. Als geografische studie betoogt het, wil het overreden, overtuigen. Als literair werk wekt het de indruk dat er iets is gemaakt, een object, in Mooijs termen, dat naast de kennis die het overdraagt en de effecten die het teweegbrengt 'zelfstandige waarde pretendeert te bezitten' (Mooij (1981): p. 2). Tegelijkertijd suggereert het notebook een suburbane werkelijkheid te beschrijven, bepleit het deze op een bepaalde manier te interpreteren en roept het een bepaalde werkelijkheid op. Als tekst die een buitenwijk op deze wijzen weet neer te zetten, is Couplands stuk een waardevolle bijdrage aan de verbeelding van suburbia. Het schetst een beeld dat we nog niet kenden en vraagt bovendien aandacht voor hoe het in elkaar steekt. Misschien overtuigt alleen een verwarrend portret als dit ons ervan dat de suburbane droom aan het eind van de twintigste eeuw tegelijk springlevend is en ten dode is opgeschreven. 

7

Tijd voor suburbia

Conclusie 



\section{American Beauty}

Dit is mijn buurt, dit is mijn straat, dit is mijn leven. Zo leidt de gedesillusioneerde Lester Burnham de film American Beauty (1999) in. Hij is tweeënveertig jaar en zal binnen een jaar dood zijn. Burnham maakt niet de indruk dat erg te vinden. 'In a way,' bekent hij, 'I'm dead already.' Wie Sam Mendes' film heeft gezien, heeft een idee van het traditionele sarcasme waarmee het Amerikaanse suburbia wordt verbeeld. $\mathrm{Al}$ in de inleiding ligt in de buitenwijk van de Burnhams over de stereotiepe glorie een al even stereotiepe schaduw.

Net als American Beauty herneemt ook Happiness (1998) veel klassieke elementen uit de verbeelding van suburbia. Wie Todd Solondz' film kent, weet echter ook dat de negatieve representatie van de middle-class suburb vandaag de dag anders in elkaar steekt dan pakweg een halve eeuw geleden. Waar American Beauty onderhoudend is en op de lachspieren werkt, doet Happiness ons het lachen vergaan. De buitenwijk en haar bewoners moeten het al decennialang ontgelden, maar een portret dat $z o$ grimmig is, was vijftig jaar geleden ondenkbaar.

Dat er naast continuïteit sprake is van variatie zien we ook in de fotografie. Hoe verschillend zijn de beelden in William Egglestons Guide (1976) en Marc Räders Scanscape (1999). Vergelijken we de foto's van beiden, dan doen we er goed aan niet alleen te letten op wat er is afgebeeld, maar vooral ook op hoe we het te zien krijgen. Beiden suggereren dat er in suburbia iets mis is, maar de suspense is het resultaat van heel andere middelen. Egglestons humor en absurdisme maken bij Räder plaats voor vervreemding. En waar Eggleston een verhaal suggereert, gebeurt in Räders buitenwijken helemaal niets. Toch krijgen we de indruk dat er iets aan de hand is. Wie een suburb in Scanscape voor het eerst ziet, zweert naar een maquette te kijken. Het is er te nieuw, te mooi en te stil om waar te zijn. Wie echter blijft kijken en wie de rest van het boek doorbladert, komt tot de 
conclusie dat niet een schaalmodel, maar een echte, zonnige Californische buitenwijk is vastgelegd. Räders foto's leveren zo een geraffineerd soort suburbiakritiek. Zonder dat we de buurt hebben bezocht, zonder dat we met bewoners hebben gesproken, vragen we ons af wie er toch wil wonen in huizen die ook na oplevering modelwoningen in een modelwijk blijven. In een enkel beeld zet Scanscape grote, comfortabele woningen neer als huizen die maar geen thuis willen worden en portretteert het ruime wijken als gemeenschappen zonder gemeenschap. Hoe slaagt het daarin?

Ten eerste is het moment waarop de foto is genomen goed gekozen. Er is niemand op straat. De leegte in de wijk wordt daarnaast benadrukt door het verre en hoge camerastandpunt, dat afstand schept en eventuele gezelligheid geen kans geeft. Bovendien speelt de foto een fascinerend spel met scherpte en onscherpte waarmee ze letterlijk plaats problematiseert en zodoende een uitermate unheimische sfeer oproept. In een begeleidend stuk achterin het boek benut publicist en producent Elizabeth McNeil de mogelijkheden van het essay om die sfeer te schetsen. Ze tracht de vreemde focus in Räders foto's te vatten in een beschrijving van hoe ze in een nieuwbouwwijk wordt rondgeleid in modelwoningen.

I wander in a sort of daze. Marble glows cooly, velvet beckons, wood panelling sets the stage. Everything is perfectly arranged. Yet something is missing - what is it? (...) I move into the bathroom, and suddenly, everywhere I look, I see myself - I'm reflected in what seems like thousands of mirrors - I'm disappearing into infinity in every direction I turn - and in a moment of sick dizziness, I realize that I've stumbled upon what I'd felt was missing in these homes - the focal point(McNeil in Räder(1999): p. 61).

Naast deze evocatieve passage voorziet McNeil Räders foto's van een tweede context, één waarin niet een metafoor kernachtig uitdrukt wat er in de housing developments uit Scanscape ontbreekt, maar waarin een lange opsomming van citaten een kritisch beeld schetst. Met haar selectie snijdt ze tal van klassieke thema's aan uit de verbeelding van suburbia. Bekijken we de foto's in het licht van deze thema's, dan zien we naast de straten, huizen en tuintjes een streven naar privacy, veiligheid, orde, rust, autonomie en succes, maar 
ook uniformiteit, homogeniteit, anonimiteit, spanningen, afzondering en uitsluiting. Uit McNeils lange reeks zijn de volgende citaten illustratief(ibid: pp. 62-7):

It's the pioneer spirit, of course. Because you're blazing your own trail in a new community in a new place with new friends, and that's one of the threads that I think is common throughout our American history, not just - if we're talking American Dream - you know, make a new home-homestead-land development-I'm a pioneer. I didn't take up somebody else's tastes and themes, but I struck out on my own and I did it myself(Male, age 45, consultant).

We are people with a certain mindset, and we decide to live together, and then there are the others. And we don't want the others to be here (Male, age 47, executive vice president).

THERE COMES A TIME WHEN YOU MUST INVEST IN A HOME THAT DESCRIBES WHAT YOU HAVE WORKED FOR ALL YOUR LIFE (Advertisement in New Homes magazine).

In my opinion, it's owningyour own house that's the American Dream. I want to have my own house - it's part of your identity. But what happens is, you have a budget. So all your aesthetic ideas get thrown to the wind (Female, age 35, homemaker).

They are the ultimate. It's not an initial dream - I think it's a successive dream, or a progressive dream. Because you start off and you buy your first home, and then it becomes a little bit addictive, and you buy your next. I mean, we didn't buy this house because we need it, we bought it because we want it (Male, age 45, consultant).

Whatever they're afraid of, it's everywhere. All over the place (Female, age 37 , writer).

The kind of people who live here-they want to be more quiet, private. And you don't hear a thing after 10:00 or so, it's just quiet. So that was quite important to Dave. He's just so attached to how simple and easy life is here. He likes the neighbors, doesn't have to deal with them. You know, it's all about being private-this is my house, this is your house(Male, age 35, architect). 
And it's almost like being secluded - you know, it's like an oasis in the middle of a desert in that there can be a lot going on around you, but yet inside this community it can be very peaceful. Very quiet. You know, sometimes it gets to be political, and the person with the biggest mouth - the most aggressive people kind of have a way - that's just human nature - but you know, the idea of $i t$ is to have it peaceful and secluded so that you can be near a city, or near the freeway, and not have to put up with, you know, the down sides of that, and still have the convenience(Female, age 59, homemaker).

YOUR ARRIVAL AS A SUCCESS HAS COME TO YOU BECAUSE YOUR GOALS AND ASPIRATIONS ARE BEING MET, AND CERTAIN EXPECTATIONS COME WITH YOUR ARRIVAL. AT OUR HOMES, THESE WILL BE MET (Advertising flyer).

Some people say, "but the windows - you look out the windows and the neighbors are right there, so close." But you know, once you drape and shade and screen, you don't even notice it anymore (Male, age 37, real estate agent).

WE ARE BUILDING FAMILY VALUES IN THE FINEST NEIGHBORHOODS (Advertisement, cover in New Homes magazine).

Naast Räders fotografische technieken dragen ook traditionele thema's als deze bij aan de betekenis van de beelden in Scanscape. Ze zijn ermee overladen. Elk beeld is een complex samenstel, niet alleen van baksteen, staal en gras, maar evenzeer van waarden en levensstijlen, verlangens en angsten, dromen en nachtmerries. Als zodanig hebben Räders op het eerste gezicht statische foto's een temporele dimensie. Hoe nieuw Scanscape's suburbs ook zijn, ze ademen een nostalgisch verlangen naar een oudere vorm van gemeenschap. Bovendien stralen ze ambitie uit. Hier verwezenlijken bewoners hun idealen, kunnen ze hun aspiraties publiek maken en deze verdedigen tegen ongewenste inmenging van buitenaf. Räders buitenwijken belichamen zowel herinneringen aan een geïdealiseerd verleden, beloften voor een stralende toekomst als de angst dat het elk moment toch nog mis kan gaan. ${ }^{221}$ 


\section{Heartland en wasteland}

Niet alleen in films en fotografie, of televisieseries en populaire tijdschriften, ook in wetenschap en literatuur moet het Amerikaanse suburbia er telkens weer aan geloven. Zowel in uiteenlopende onderzoeksdisciplines als in verhalen en romans is de buitenwijk de afgelopen vijftig jaar vaak voorgesteld als een naargeestige en onheilspellende plek. De droom van weleer lijkt zich te hebben ontwikkeld tot een suburbane nachtmerrie. Dat er een hardnekkige negatieve verbeelding bestaat van buitenwijken en hun inwoners staat hier niet ter discussie. Wel in welke termen daarover wordt nagedacht en bijgevolg hoe erop wordt gereageerd.

Lange tijd stond het bestaan in metropolen als New York City en Los Angeles in het centrum van de belangstelling, terwijl het leven in omringende suburbs werd beschouwd als een saai randverschijnsel. Nu het inwonertal van suburbia in Amerika hoger is dan dat van stad en platteland opgeteld, is suburban studies uitgegroeid tot veel meer dan een spin-off van het stadsonderzoek en heeft zich een literaire traditie ontwikkeld die wel wordt aangeduid als a literature of the suburbs. Daarin zijn belangrijke kwesties aan de orde. Welke invloed heeft deze nieuwe woonomgeving bijvoorbeeld op de levenswijze en cultuur van zo'n grote groep mensen? Hoe ernstig is de lucht- en horizonvervuiling als gevolg van de ermee samenhangende stijging van (auto)mobiliteit? En wie woont waar? Welke consequenties heeft bijvoorbeeld de segregatie van blank en zwart, rijk en arm? Willen we antwoorden geven op deze en andere vragen, dan is een subtiel beeld van suburbia onontbeerlijk. We willen niet alleen beschikken over een rijkgeschakeerde verbeelding van de buitenwijk omdat we ook van de stad een gevarieerde representatie kennen, maar vooral ook omdat deze verbeelding via tal van individuele keuzen om zich ergens wel of niet te vestigen, via overheidsbeleid en strategische beslissingen van het bedrijfsleven haar weer- 
slag heeft op de toekomstige inrichting en vormgeving van woonen werkomgeving en het gebied daartussenin.

De traditionele aanval op stereotypen en clichés schiet tekort. Tot op de dag van vandaag wordt gesproken in termen van de zogeheten suburbane mythe. De centrale vooronderstelling luidt dat deze mythe een inaccurate weergave is van de suburbane reali teit en dat ze plaats moet maken voor realistischer representaties. Uit het oog wordt verloren dat de suburbane werkelijkheid niet eenvoudig wordt beschreven, maar dat teksten van alles in het werk stellen, zodat we de buitenwijk op een bepaalde manier te zien krijgen. Wat er precies gebeurt en wat daarvan het effect is, wordt duidelijk als uiteenlopende verbeeldingen onderling worden geconfronteerd.

\subsection{Een complex stelsel}

Allereerst suggereert het repertoire van de mythe onterecht dat de negatieve representatie van de buitenwijk een eenvoudig beeld inhoudt, terwijl andere beelden complexer zouden zijn. Zoals blijkt uit de thema's die Räders foto's aan de orde stellen en zoals in hoofdstuk 1 bleek uit onder meer Sloan Wilsons roman The Man in the Grey Flannel Suit (1955) gaat het niet slechts, zelfs niet zozeer, om de suburb, als wel om suburbia. Niet alleen de inrichting en vormgeving van de woonomgeving, vooral ook de levensstijl en mentaliteit die ermee worden geassocieerd, staan ter discussie. Vrijwel zonder uitzondering betreft het de levensstijl en mentaliteit van de middenklasse. Pijlen die zijn gericht op suburbia zijn bedoeld voor deze middenlaag. Zowel de aard van de gemeenschap als de sociale identiteit van individuele bewoners moet het ontgelden.

Confronteren we uiteenlopende teksten en concentreren we ons op hoe de middenklasse wordt gepresenteerd, dan valt op dat de vele ranch houses, station wagons en keurige gazonnetjes niet alleen een verband uitdrukken tussen plaats en identiteit, maar evenzeer tussen identiteit en tijd. Steeds krijgt met een bepaalde plek en levensstijl een temporele oriëntatie gestalte, een betrokkenheid op verleden, heden en toekomst. Met haar vrijstaande woningen, garages en achtertuintjes wordt de ene wijk neergezet als een gemeenschap die koste wat kost wil veiligstellen wat is bereikt en bang is 
voor verstoring van de status-quo, terwijl een andere zich hedonistisch op het nu richt en zich bekommert om verleden noch toekomst en weer een andere juist optimistisch vooruitblikt, omdat ze vóor alles gelooft in vooruitgang. Met voorstellingen van deze tijdperspectieven gaan bovendien opvattingen gepaard over de handelwijzen van de middenklasse. Terugkijken en vooruitblikken worden gekoppeld aan angst en conformisme, maar ook aan vastberadenheid en egoìsme, een gebrek aan initiatief of juist een overmaat aan dadendrang.

\subsection{Continuîteit}

Vergelijken we deze complexe constructies en vestigen we de aandacht op het verband van tijd met plaats en levenswijze, dan blijkt een zekere continuilteit - niet slechts in teksten die de buitenwijk in de loop der tijd als een stereotype neerzetten, zoals in het repertoire van de mythe wordt gesuggereerd, maar evengoed in portretten waarin heel verschillende, zelfs verrassende aspecten van het suburbane wonen worden uitgelicht. In hoofdstuk 2 bleken de jaren vijftig in dit verband een sleutelrol te spelen. Een terugkerend motief in de verbeelding van de buitenwijk is de fifties-suburb als wat wel de true site of middle America wordt genoemd. Drie compromissen komen daarin bijeen, georganiseerd rond een hecht verband tussen de ideale Amerikaan, de zogeheten nieuwe middenklasse en de naoorlogse buitenwijk. De ideale Amerikaan combineert individualiteit met gemeenschapszin, maakt als onafhankelijk individu deel uit van een harmonieuze groep. De nieuwe middenlaag van voornamelijk kantoorklerken zou in een stabiel gezin en individuele loopbaan uitdrukking geven aan de combinatie van rust en prestatiedrang. Wordt deze klasse als geheel geportretteerd, dan streeft ze op basis van een traditioneel, hecht gezinsleven sociaal-economische mobiliteit na. Wordt ze opgedeeld in een lower- en upper-middle class, dan tonen de solid citizens uit de eerste zich vooral tevreden met wat ze hebben, terwijl de carrièremakers uit de laatste ambiëren hogerop te komen en een hypergevoeligheid voor statusverschillen aan de dag leggen. Het sociaal-politieke compromis tussen individualiteit en gemeenschap en het economische tussen rust en presteren 
komen samen in een derde, temporeel compromis. In de fifties.uburb zou zowel stabiliteit als vooruitgang tot uitdrukking kosen. Afhankelijk van hoe de buitenwijk wordt opgevoerd, kunne we twee vormen van status anxiety onderscheiden. Staat een afzoderlijke suburb centraal, dan is meestal sprake van een collectief treven naar behoud van sociale status. Wordt daarentegen gedact in termen van een mozaìek van suburbs, dan staat veeleer carrièreentraal, waarbij verhuizen in suburbia gelijk staat aan verhuize op de maatschappelijke ladder.

Sinds de jaren vijftig geldt de buitenwijk zo als de plek biuitstek waar de middenklasse uitdrukking geeft aan het Amerikanse ideaal van thuis zijn en vertrekken. Grote verhalen over het autnome individu, het harmonieuze gezin, de stabiele gemeenscap, powaarrse mobiliteit en materiële voorwitgang raken verstreggeld en maken de true site of middle America tot een robuuste notie. Daaraan wordt bovendien nog bijgedragen door een vijftal culturele ideeën die niet alleen in het denken over de buitenwijk, maar ook over Amerika als geheel een lange traditie hebben. Het paradijs, de pastorale, het pittoreske, de frontier en de stad vormen een voorraad ideeën - zowel over plaats, tijd als identiteit - waaruit kan worden geput voor zowel de verbeelding van gemeenschap als individualiteit, zekerheid als vernieuwing, nostalgie als ambitie. Afhankelijk van de specifieke gedaante van de buitenwijk wordt hierop teruggegrepen. Het paradijs en het pittoreske lenen zich bijvoorbeeld voor een beeld van volmaakte, (al te) zorgvuldig geregisseerde rust in een fraaie, groene omgeving. Staat niet thuis zijn, maar vertrekken centraal, dan wordt vaak een verhaal verteld in de frontier-traditie, waarin ondernemende individuen hun lot in eigen hand nemen, en dat van anderen negeren. Krijgt een combinatie van beide uitdrukking, dan wordt vaak een beroep gedaan op de (Amerikaanse) pastorale, die een onbedorven plattelandsbestaan paart aan geloof in vooruitgang.

Dit complexe stelsel levert in de verbeelding van suburbia continuîteit op. De afgelopen vijftig jaar mogen afzonderlijk vergelijkingen, associaties, opposities en connotaties zijn gekritiseerd, de formule als geheel is niet bezweken. Als constante is ze terug te vinden in de representatie van de buitenwijk als ideaal en schrikbeeld. 


\subsection{Strijd}

De waarderingen lopen nogal uiteen. In Robert Sterns architectuurgeschiedenis Pride of Place (1986) geldt suburbia bijvoorbeeld als 'a glory of American life' (Stern (1986): p. 158), in Thomas Hine's designstudie Populuxe (1986) wordt het opgevoerd als 'the heartland of the American people' (Hine (1999): p. 170), terwijl het in David Karps roman Leave MeAlone (1957) wordt getypeerd als een 'social fiction of snug little homes filled with snugly harmonious devotees of barbecue cooking, lawn care and Eisenhower republicanism' (Karp (1965): p. 221). Op basis van hetzelfde, beperkte vocabulaire geldt suburbia als belofte en teleurstelling. De vraag wat er wordt klaargespeeld, wordt heel verschillend beantwoord. Afhankelijk van dat antwoord valt de suburb ondanks hardnekkig terugkerende moticven in uiteenlopende teksten in verschillende gedaanten aan te treffen. En met haar de middenklasse. Laten we ons niet verleiden tot het repertoire van de mythe, maar vergelijken we verschillende gedaanten onderling, dan blijkt de vraag naar wat er wordt gepresteerd onlosmakelijk verbonden met die naar wie er iets doet en hoe het wordt gedaan.

In hoofdstuk 3 bleek de buitenwijk een strijdtoneel waarop intellectuelen op drie punten het gevecht aangaan. Afhankelijk van wat zij verwachten van het individu en verstaan onder handelen en handelingsbekwaamheid, schetsen ze onderling concurrerende versies van suburbia. Het eerste issue is verlies van individualiteit. $\mathrm{Er}$ is niet alleen kritiek op de gebouwde omgeving, ook bewoners gelden als een mislukking. In de monotone suburb leeft een angstige, afhankelijke en overmatig conformistische middenklasse die aloude Amerikaanse idealen als initiatief, autonomie en daadkracht beschaamt. Critici als Mumford, Huxtable, Mills, Whyte en Riesman schetsen een dystopisch suburbia waarin groepsdwang elke uiting van individualiteit de kop indrukt. Nog steeds levert deze traditie tot de verbeelding sprekende pessimistische typeringen op. James Kunstler trekt bijvoorbeeld ouderwets fel van leer tegen buitenwijken als

a landscape of scary places, the geography of nowhere, (...) monoculture tract developments of cookie-cutter bunkers on half-acre lots 
in far-flung suburbs (...). One looks upon new home construcion as the cancer patient must contemplate the spread of malignar cells through his healthy tissue (Kunstler(1994): pp. 15, 147-8).

Socioloog David Hummon laat in Commonplaces (1990) een antal stedelingen aan het woord:

I don't think there's an identity to a suburb. (...) Small town have taste, big towns have taste, and they vary from one to anothe. But suburbs are all the same-it's vanilla whether it's East coast or Vest.

What you're stuck with is your typical, little housewife wit nothing to talk about except the butter going up three cents. A busewife and a station wagon hauling kids around. Theg, have wery shallow existence. They have nothing to do but watch the next-door neighbor and see if they got a new, bigger station wagon.

When I think of a suburb, I just have this vision of these little, wooden people who are turned out at a factory ... everybody is the same. They have the same ambitions, the same goals (Hummon (1990): pp. 86-7).

Dit beeld van inwisselbare kuddedieren berust op een bepaalde opvatting van consumptie, een tijdsbesteding die traditioneel van groot belang wordt geacht voor het suburbane bestaan, en waarover de meningen nogal verschillen. Wordt consumeren niet opgevat als passief hedonisme, maar als een betekenisvolle activiteit in zowel het persoonlijke als gemeenschapsleven, dan krijgen we een heel andere versie van de buitenwijk te zien. Bewoners drukken met een nieuwe auto of tijdens een gezamenlijke barbecue overeenkomsten en verschillen uit, en geven in de stijl van hun huizen blijk van zowel nostalgie als ambitie. De doe-het-zelver heeft in deze versie niet als conformistische slapjanus de teloorgang van aloude idealen op zijn geweten, maar draagt op zijn eigen manier bij aan de vormgeving van de suburb. Hij geeft op eigen wijze invulling aan een Amerikaanse droom.

Naast individualiteit en kuddegeest, passiviteit en activiteit organiseren lot en wil verschil, vooral in geschiedenissen van sub- 
urbia. In de ene brengt een visionaire middenklasse op eigen kracht suburbia tot bloei. In andere versies wordt haar handelingsvrijheid aan banden gelegd en zelfredzaamheid in twijfel getrokken. Onder meer demografische ontwikkelingen, technologische innovaties, botsende belangen van allerlei lobbygroepen en een flinke overheidssteun zwakken het beeld van de autonome middenklasse als motor van de geschiedenis danig af. Wordt, tot slot, het einde van de traditionele buitenwijk ingeluid, dan verdwijnt in de ene geschiedenis de middenklasse als handelende actor volledig uit beeld, terwijl in de andere tussen verschillende, steeds verschillender bewoners een heftige strijd losbarst om de invulling van laat- of postsuburbia. Ieder heeft zijn eigen verwachtingen. Zo kijken nieuwkomers hoopvol vooruit, terwijl sommige oudgedienden nostalgisch terugblikken en andere uit angst de poorten sluiten. 


\section{Betogen en verhalen}

De negatieve verbeelding van suburbia mag dan hardnekkiz zijn, concurrerende versies van de buitenwijk en haar bewoners lijken dus wel degelijk voorhanden. Niet de suburbane mythe is htt probleem, maar het denken in termen van een mythe. Ze lijkt in het suburbiaonderzoek een verplicht passagepunt. Wie deel wil titmaken van een groep kritische geesten, neemt de mythe als afze punt. Dat kan bijdragen aan een gevoel van 'vakbroederschap' en helpen een wetenschappelijke discipline te legitimeren ten opzichte van de buitenwacht ${ }^{222}$, maar daarvoor wordt een hoge prijs betaald. De negatieve verbeelding van de buitenwijk wordt veel te eenvoudig voorgesteld en de cruciale koppeling tussen suburb en middenklasse raakt aan het zicht onttrokken.

Opmerkelijke relaties tussen die twee vinden we niet alleen in sociaal- en geesteswetenschappelijke studies, ook in de literatuur worden intrigerende verbanden geschetst tussen de buitenwijk als plaats en de temporele oriëntatie en identiteit van haar bewoners. Van literaire verhalen wordt vaak verwacht dat ze verbeelding verrijken, in het bijzonder als het gaat om tijd. ${ }^{223}$ Romans en verhalen zouden aan bestaande beelden van suburbia en zijn inwoners nieuwe kunnen toevoegen, het bekende vreemd kunnen maken, voor dominante beelden alternatieven kunnen presenteren en stereotypen kunnen ondermijnen. ${ }^{224}$ John Keats' The Crack in the Picture Window (1956) en David Karps Leave Me Alone laten eerder het tegenovergestelde zien. Beide schetsen een eendimensionaal beeld van monotone buitenwijken bevolkt door een angstige, bekrompen middenklasse. Maar de literatuur biedt ook subtielere, complexere verhalen. Richard Yates' Revolutionary Road (1961) voert Frank Wheeler op, die lijkt te strijden voor individualiteit en verandering, maar uiteindelijk een onbetrouwbare, behoudzuchtige lafaard blijkt. Niet zozeer zijn medebewoners, maar hijzelf maakt de bui- 
tenwijk tot een uitermate benauwend oord. Nog benauwder wordt het in Gloria Naylors Linden Hills (1985). Dat er iets niet pluis is, is van meet af aan duidelijk. We reizen door de tijd en krijgen de wijk vanuit verschillende perspectieven te zien-door de ogen van jong en oud, arm en rijk, bewoners en buitenstaanders -, maar gezellig wordt het nooit. Als we worden meegenomen in de belevingswereld van een vrouw die er in een kelder is opgesloten, is er geen ontkomen meer aan: het gevoel van verstikking dat de meeste suburbiaverhalen oproepen, wordt regelrechte horror. Waar we die horror misschien zouden verwachten, in Jeffrey Eugenides' The Virgin Suicides (1993), is hij juist grotendeels afwezig. Vijf jonge zusjes plegen zelfmoord, maar in het beeld dat de verteller in retrospectief van zijn jeugdervaringen schetst, overheerst nostalgie.

Beweringen over de literaire verbeelding van suburbia in het algemeen, alsook over haar aanvulling op de sociaal- en geesteswetenschappelijke representatie in het algemeen, zijn niet zinvol, luidt een belangrijke conclusie van dit onderzoek. Vergelijking van verschillende verhalen onderling en van deze verhalen met verschillende wetenschappelijke betogen des te meer. Kijken we naar de suburbs die in hoofdstukken 2 en 3 de revue passeerden, dan stellen we vast dat verhalen in sommige opzichten helemaal niet zoveel van betogen afwijken. Betoog- en vertelstrategieën verschillen gradueel en het is niet zo dat sociaal-wetenschappelijke studies naar de suburbane werkelijkheid verwijzen en literaire verhalen niet. Zeker, sommige buitenwijken waaraan betogen refereren, kunnen we daadwerkelijk bezoeken. Andere, echter, bestaan niet meer, doordat ze zijn afgebroken, of zijn niet of nauwelijks meer te onderscheiden van hun omringende omgeving, doordat ze zijn opgeslokt door de stad. Over weer andere is materiaal verzameld toen ze nog gebouwd moesten worden. Planologische en promotieteksten, bijvoorbeeld, hebben betrekking op wijken die nog niet bestaan. In die zin zijn ze fictioneel, stelt Age Niels Holstein in cen artikel over (de toen nog te bouwen)Amsterdamse Vinex-wijk IJburg.Ze roepen een niet-bestaande werkelijkheid op, een eigenschap die ze delen met literaire verhalen (zie Holstein (1998): pp. 370-1). ${ }^{225}$ In sommige sociaal-wetenschappelijke studies, bijvoorbeeld William Dobriners Class in Suburbia (1963), wordt zelfs nadrukkelijk gesteld dat niet 'feitelijke' buitenwijkbewoners worden gepresenteerd, maar ide- 
aaltypen, die we in de suburbane werkelijkheid niet zullen aantreffen. Dat deze toch de indruk wekken een realistische beschrijving te zijn, is het resultaat van verteltechnieken en stijlmiddelen die we eerder met literatuur dan wetenschap associëren. Zo wekt Dobriner een type tot leven door het onder meer een eigen, individuele geschiedenis mee te geven, door een eigen stem en taalgebruik te suggereren en ons als lezer door middel van een spel met focalisatic de indruk te geven door een straat in Levittown te lopen.

Andersom benadrukt de verteller in Keats' The Crack in the Picture Window dat het Rolling Knolls uit zijn verhaal over John en Mary Drone wel 'op feiten is gebaseerd'. Hij geeft toe dat het niet bestaat, maar benadrukt dat het, helaas, overeenkomt met de werkelijkheid. Zijn verhaal over het ongelukkige echtpaar is ingebed in een vlammend betoog tegen suburbia. Te midden van allerlei experts die de verteller opvoert om aan te tonen hoe erg het wel niet is gesteld met het leven in de suburb, moeten de Drones de aanklacht illustreren. Karps Leave Me Alone, tot slot, is een roman. Maar ook hierin vallen verhaal en betoog niet eenvoudig te onderscheiden. Door de vertelling over suburbanisant Arthur Douglas is als een rode draad een sociologische studie geweven, niet van een 'echte' expert, zoals in Keats' verhaal, maar van de fictionele professor Cameron, die deel uitmaakt van de wereld van de personages. Zijn uiteenzetting verschilt nauwelijks van Mills', Whyte's en Riesmans invloedrijke kritieken. De lezer wordt verleid zich met Arthur te identificeren, maar krijgt gaandeweg steeds sterker de indruk dat het in Karps roman niet om hem draait, maar om de buitenwijkbewoners waarmee hij overhoop ligt. Als illustratie bij Camerons model worden zij als de vleesgeworden Little Man, Organization Man en other-directed te kijk gezet.

Zelfs als we erkennen dat deze weifelende buitenwijkbewoners de verbeelding domineren, vallen in tal van teksten afwijkende suburbanisanten aan te treffen. Vergelijking maakt duidelijk dat kleine verschillen tussen uiteenlopende vormen van verbeelding grote consequenties kunnen hebben voor de wijze waarop suburbia wordt neergezet. Wie bekijkt in welke gedaanten buitenwijken en hun inwoners opduiken, moet letten op hoe deze totstandkomen. Met het wat moet het hoe aan de orde zijn.

John Updike's Rabbit, Run (1960) en Couples (1968) vertonen over- 
eenkomsten met bijvoorbeeld Whyte's en Riesmans aanvallen op de buitenwijk. Zowel wat betreft autonomie, initiatief, visie als daadkracht kunnen we hoofdpersonages Harry Angstrom en Piet Hane$\mathrm{ma}$ mislukkelingen noemen. Bovendien brengen zij niets terecht van de combinatie van terugblikken en vooruitzien, nostalgie en ambitie die idealiter in suburbia tot uitdrukking zou komen. De wijze waarop het bestaan in Mt. Judge en Tarbox gestalte krijgt, verschilt echter van Whyte's en Riesmans kritieken. In hoofdstuk 4 bleek dat Updike's romans bijzondere bijdragen leveren aan de verbeelding van suburbia.

Rabbit, Run presenteert Harry's overmatige nostalgie en gebrek aan toekomstvisie als een acuut probleem. In Rabbits bestaan overheerst een gevoel van beklemming, georganiseerd rond een onafzienbare reeks alledaagse problemen. In een vertelling die is gestructureerd als een neerwaartse spiraal keert hij zich steeds meer naar binnen. Hij draait letterlijk - in steeds kleinere ruimten - in steeds kleinere kringetjes rond. Gevangen in zijn eigen, steeds beperkter blikveld, ziet Harry geen kans afstand te nemen om te reflecteren opde puinhoop in zijn leven. Waar in de betogen van onder anderen Riesman en Lee nadrukkelijk een toetssteen wordt geěxpliciteerd, krijgt zo in Rabbit, Run een impliciete suburbiakritiek uitdrukking. Bovendien houdt het oordeel in Rabbit, Run geen veroordeling in. Ook al is Harry vaak ronduit egocentrisch, begrip van zijn omstandigheden laat de mogelijkheid open begrip op te brengen voor zijn twijfel en stuurloosheid.

Net als Rabbit, Run bespeelt Couples verschillende registers. Het begeeft zich op het snijvlak van het realistische, symbolische en burleske, wat een intrigerend samenspel oplevert tussen venijn, ontzag, humor en mededogen. Een bepaalde levenswijze moet het ontgelden, maar nooit zonder wat Updike heeft omschreven als een 'respectful identification with the people of one's locale', niet alleen in 'menacing cities', maar evenzeer in 'disposable suburbs' (Updike (1976): p. 489). In tegenstelling tot Rabbit, Run velt Couples een expliciet oordeel. Niet alleen de personages uiten in innerlijke monologen, dialogen en gedrag hun afkeer van het suburbane bestaan, in tegenstelling tot Rabbit, Run houdt ook de verteller zijn mening niet voor zich. Waar Piet Hanema nog op de nodige compassie kan rekenen, is er vooral op de vriendenkring als geheel stevige kritiek. Zijn 
hedonistische, cyclische bestaan in afzondering van de baitenwe reld wordt gepresenteerd als mislukt escapisme, zijn rd in het publieke domein als een vorm van handelen waarmee her met de komst van een jongere generatie suburbanisanten snel is getaan.

Couples' beeld van Tarbox' paren koppelt een expliciet cultuurkritische diagnose zoals we die kennen uit Richard Sennetts en Christopher Lasch' studies aan wat het voor de stellen betekent idealen verloren te zien gaan en verlangens gefrustreerd te zien worden. Uitgangspunt is steeds de alledaagse ervaring - 'the flux, the blurring, the endless innuendo of experience as we feel it,' in Updike's eigen woorden. ${ }^{226}$ De paren reflecteren daarop, de verteler laat hun gedachten overvloeien in achtergrondschetsen en commentaar waarin het kleine het grote symboliseert. Couples is daarnee niet noodzakelijkerwijs complexer dan sociaal-wetenschappelijke betogen, zoals Elizabeth Long bijvoorbeeld suggereert met haar tweedeling tussen complexe literatuur en schematische sociale wetenschap in The American Dream and the Popular Novel (zie Long (1985): hoofdstuk 1). Wel weeft het reacties van uiteenlopende personages en de verteller tot een geheel waarin onderlinge verschillen en spanningen merkbaar blijven, niet tot één standpunt worden herleid. Bovendien nodigt het de lezer niet alleen uit zich te verhouden tot stellingen en argumenten, maar ook zich te identificeren met uiteenlopende personages en houdt het ons zelfs een spiegel voor. Door te overtuigen, verleiden en confronteren, nodigt Couples ons uit ons denken en voelen nog eens tegen het licht te houden. Het leunt, net als veel sociaal-wetenschappelijke betogen, op een aantal bekende onderdelen uit de verbeelding van de buitenwijk - denk aan het paradijs en de pastorale -, het is georganiseerd rond clichés - denk aan suburbaan overspel -, maar weet ons op geraffineerde wijze daarop te betrekken. Niet door frontaal de aanval te zoeken, door bijvoorbeeld het cliché de oorlog te verklaren, maar door de ruimte die de literatuur biedt zoveel mogelijk te benutten: gedachten en gedragingen voor te stellen als een tegelijkertijd begrijpelijke, verleidelijke, verachtelijke, lovenswaardige en belachelijke levensstijl.

Waar Updike's romans genregrenzen respecteren, sluipen in Douglas Couplands Generation X (1991) vreemde elementen binnen. De hoofdvertelling wordt in de marge omringd door een verklarend en kritisch kader van kreten, cartoons, neologismen en aforis- 
men en krijgt een cijfermatige onderbouwing in de vorm van een appendix met allerlei statistieken. Ze brengen ontwikkelingen bijeen die in verschillende tradities aan de orde zijn gesteld. Zo kunnen we Andy, Dag en Claire's problemen begrijpen in de context van de overconsumptic en milieuvervuiling, de gezinsproblematick en verdwijnende middenklasse zoals die in tal van verhalen en romans zijn verbeeld. Willen we hun neerwaartse mobiliteit in context plaatsen, dan moeten we uitwijken naar sociaal- en geesteswetenschappelijke studies. Samen maken ze de wereld uit waarin de drie de weg kwijt zijn en zich opnieuw moeten zien te oriēnteren.

In hoofdstuk 5 bleek dat hoofdvertelling, margelexicon en appendix door onderlinge verwijzingen begrijpelijk zijn in elkaars termen. Daardoor krijgt een gesloten wereldbeeld gestalte waarin inzichtelijk wordt waarom drie jonge leden van de middenklasse zich terugtrekken in de woestijn. In een tijd waarin realisatie van de Amerikaanse droom binnen handbereik lag, is Andy, Dag en Claire veel beloofd. Begin jaren negentig is de uiterste houdbaarheidsdatum van veel beloften echter verstreken en zijn de drie op zoek naar een nieuw toekomstperspectief. Begrijpelijk wordt waarom het, zelfs in het perifere Palm Springs, niet eenvoudig is het middenklassekader dat hen heeft teleurgesteld, af te werpen. Vooral als het gaat om verwachtingen, blijkt het verleidelijk daarbinnen houvast te zoeken. Niet vooruitblikken levert de drie uiteindelijk een toekomstbeeld op, maar terugkijken. Andy en zijn vrienden verlangen naar een toekomst uit het verleden, de toekomst waarmee hun ouders groot werden en die voor de generatie $X$ een onhaalbaar ideaal is gebleken.

Dat de drie zich in de marge terugtrekken en zich daar stilhouden, betekent in Generation $X$ niet dat ze uit het verhaal worden weggeschreven. Hoe aarzelend en omzichtig Andy, Dag en Claire ook te werk gaan, in Palm Springs slagen zij erin al pratende, doende en vooral vertellende een kleine stap voorwaarts te zetten. Hoe bescheiden ook, hun gefluister en getast wordt in Couplands roman hoorbaar en zichtbaar. Zo biedt Generation $X$ een alternatief voor de verdwijntruc in Fishmans Bourgeois Utopias (1987) en voegt het aan het geroep, geduw en getrek in bijvoorbeeld Kling, Olin en Posters Postsuburban California (1991) een stem en handelwijze toe.

Een heel ander (post)suburbaan Californië krijgt, tot slot, gestal- 
te in Couplands 'Brentwood Notebook' (1996), een bijzonder portret van een van Los Angeles' welvarende buitenwijken. De inwoners van Brentwood lijken niet echt geïnteresseerd in hun wijk of in elkaar, maar weten niettemin de rijen te sluiten als het gaat om bescherming tegen invloeden van buitenaf. De wijk wordt neergezet als een gemeenschap die koste wat kost wil veiligstellen wat is bereikt. Ze is betrokken op verleden noch toekomst, is slechts geìnteresseerd in bewaking van de status-quo, ook al is dat in dynamisch L.A. met de dag moeilijker vol te houden.

In hoofdstuk 6 werd duidelijk dat in Couplands notebock een allesbehalve traditioneel portret wordt geschetst. Het aantekeningenschrift plaatst nadrukkelijk op de voorgrond wat in de verbeelding van suburbia gewoonlijk verhuld blijft. Niet alleen wat wordt verbeeld, ook wat daarvoor in het werk wordt gesteld vraagt de aandacht. Ten eerste wordt een spel gespeeld met het werkelijkheidsgehalte van Brentwood. Als buitenwijk van L.A. bestaat het wel en niet, als utopisch ideaal is het de ene keer wel, de andere keer niet verwezenlijkt en als dystopie is het een nachtmerrie die aan de Amerikaanse westkust al realiteit is en in de toekomst wellicht ook in Europa werkelijkheid zal worden. Dat Couplands Brentwood niet eenvoudig is, maar op een bepaalde manier wordt opgevoerd, blijkt daarnaast uit de bonte verzameling waaruit het portret is samengesteld. Couplands observaties en overwegingen zijn verweven met fragmenten uit onder meer tijdschrift, krant, betoog, roman, advertentie en menukaart. Bijzonder is dat de lay-out van het notebook de naden van dit weefsel nadrukkelijk zichtbaar maakt, waardoor we een deel van de arbeid krijgen te zien die moet worden verricht, wil een portret van de buitenwijk overtuigen. Een derde wijze waarop 'Brentwood Notebook' de lezer alert maakt, hangt hiermee samen. Het combineert strategieèn uit verschillende genres, maar lapt conventies uit diezelfde genres aan zijn laars. Het wekt de indruk een verslag te zijn van een bezoek aan een buitenwijk, maar in tegenstelling tot wat we gewend zijn van de reportage komen bewoners zelf niet aan het woord. Daarnaast betoogt het notebook, maar niet op basis van de stapsgewijze argumentatie die we kennen uit cultuurgeografische en sociologische studies die net als het notebook afgeschermde, angstige suburbs portretteren. Als literair werk, tot slot, roept het notebook een ambigue en unheimische wereld op. Maar 
hoewel we de spanningsboog kennen uit romans als John Cheevers Bullet Park (1967), Gloria Naylors Linden Hills en T.C. Boyle's The Tortilla Curtain (1995), wordt geen verhaal verteld waarin we fictionele personages leren kennen. In het notebook verstoort afstand identificatie, zoals fascinatie de analyse onderbreekt en Couplands betrokkenheid de suggestie van objectiviteit ondermijnt. Wie verwacht te vernemen hoe het leven in een buitenwijk als Brentwood er werke. lijk uitziet, komt van een koude kermis thuis. 


\section{4 \\ Een kijk op tijd}

Tijd speelde in dit proefschrift een sleutelrol. Door de aandcht te vestigen op hoe tijd ruimtelijk wordt verbeeld, kon allererst de suburbane mythe worden opengebroken. In suburbia's vejeelde geografie zijn plaatsbeelden steeds tijdbeelden, voorstellinęn van de temporele oriëntatie van de middenklasse die in de buiłnwijk neerstrijkt. Om die suburbaniserende middenklasse gaat kt uit-

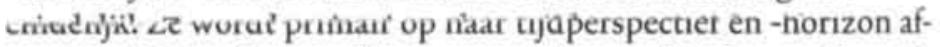
gerekend. Niet alleen omdat ze overmatig nostalgisch zou zijn, zich zou verliezen in een hedonistisch heden, of juist blinde ambitie aan de dag zou leggen, maar ook omdat terugblikken en vooruitkijken worden gekoppeld aan handelingsoriëntatie en zelfs handelingsbekwaamheid. Het gaat niet alleen om terugverlangen en verwachten, maar evenzeer om angst voor verandering en de daaraan verbonden behoudzucht, de in de Amerikaanse cultuur zo gewaardeerde autonomie en de door commentatoren verachte aanpassingsdwang, en een tekort aan ondernemerschap of juist een overmaat aan geldingsdrang.

Door tijd als invalshoek te kiezen, bleken bovendien ondanks de decennialange reproductie van een beperkt aantal overbekende, dominante beelden wel degelijk concurrerende, zelfs verrassende versies van de buitenwijk en haar inwoners voorhanden. Invloedrijke suburbiakritieken verschillen onderling. Ze leggen verschillende verbanden tussen gebouwde omgeving, tijdperspectief en levensstijl, en verstaan onder 'de middenklasse' heel andere groepen, variërend van een behoudende en conformistische lower-middle class tot een overambitieuze en egoïstische upper-middle class. Tegenover deze kritiek staan bovendien alternatieven, die elk een eigen kijk op tijd presenteren en 'typisch' middenklassegedrag verschillend waarderen. Dat geldt niet slechts voor sociaal-en geesteswetenschappelijke studies. Vooral als het gaat om tijd, blijken in de literatuur intrige- 
rende varianten te vinden. In uiteenlopende werken troffen we suburbs, wegen, huizen en tuinen aan die als chronotopen de verbeelding organiseren. Plaats, tijd en identiteit komen daarin in onderlinge samenhang tot uitdrukking en geven bovendien gestalte aan algemener, vaak normatieve opvattingen over levensstijlen, maatschappij en cultuur. In de verbeelding van suburbia zijn duidelijk niet alleen argumenten, maar ook opinies, emoties en waarderingen in het spel. Wanneer wordt gemeenschapszin conformisme? Wanneer wordt nostalgie verlamming, rust apathie, autonomie egoïsme, ambitie status anxiety en privacy isolatie? Hoe de vraag ook luidt, 'de feiten' geven daarop geen antwoord. Integendeel. Afhankelijk van het antwoord krijgen we uiteenlopende 'feiten' gepresenteerd.

In dit proefschrift stond de middenklasse centraal. In het verlengde van dit onderzoek kunnen diverse paden worden ingeslagen om verschillende vormen van maatschappij- en cultuurkritiek die in de representatie van suburbia zitten verpakt, nader te bekijken. Gaat de aandacht uit naar grote woorden en verhalen, dan kunnen vooruitgangsdenken en claims als de emancipatie van de middenlaag en de democratisering van wooncomfort onder de loep worden genomen, en kunnen bekende vertellingen worden doorgelicht, zoals die waarin de reis van oost naar west wordt voorgesteld als een trip van verleden naar voorland. Dat is niet alleen zinvol als het gaat om buitenwijken tussen de Amerikaanse oost- en westkust, maar ook in het kader van de veelgemaakte vergelijking tussen het suburbia in de nieuwe wereld en de buitenplaatsen, tuinwijken, groeikernen, Vinex-locaties en polycentrische Deltametropool in onze oude.

Wie niet uit- maar inzoomt, kan zich binnen de middenklasse concentreren op de verbeelding van man en vrouw. Traditioneel wordt bijvoorbeeld vooral van de man verwacht dat hij visie heeft en daadkrachtig optreedt. 'Mannelijke' problemen in suburbia lijken daardoor te verschillen van 'vrouwelijke'. Waar de man zou lijden aan een gebrek aan vrijheid, zouden vrouwen vooral eenzaam zijn. Maar waarom is het dan juist Betsy die in het Westport uit Sloan Wilsons The Man in the Grey Flannel Suit de lakens uitdeelt en niet haar man Tom? En waarom tekent in Alice Hoffmans Local Girls (1999) niet eenzaamheid, maar juist beklemming Gretels leven in 
Franconia? Een ander onderscheid tussen leden van de middenklasse onderling is dat tussen zwart, bruin en blank. Ze fokken kippen en hangen hun was in de voortuin te drogen, klaagt een bewoner van L.A. in Fred Siegels The Future Once Happened Here (1997). Bovendien houden ze niet van gazonnetjes: 'They don't like grass. That's why we moved out'(Siegel (1997): p. 156). Waarom is het verrassend dat het hier niet een blanke betreft die zijn vlucht voor zwarten verwoordt, maar een African American die klaagt over Mexicanen? En waarom verwachten we een uitlating als deze eerder van een kantoorklerk dan van de vrachtwagenchauffeur die hier aan het woord is? Houden truckers niet van een fraai gazon, of kan het zijn dat het hier niet slechts draait om het uitzicht op een mooi voortuintje, maar ook om een bepaalde kijk op tijd? 


\section{Noten}

1. Omdat ik niet naar de Amerikaanse uitgave uit 1955, maar naar de Engelse uit 1956 verwijs, hanteer ik de Engelse titel met 'grey' in plaats van 'gray'.

2. Vergelijkbaar zijn Sloan Wilsons inleidende opmerkingen in zijn autobiografische What Shall We Wear to This Party? (1976). Opvallend is dat nadrukkelijk Toms levenshouding - eerder dan die van Betsy - exemplarisch zou zijn voor het suburbane bestaan. In het algemeen geldt dat in teksten over de buitenwijk de man, als forens, het uitgangspunt vormt. Dat geldt zelfs voor de man in zijn thuissituatic, terwijl toch meestal wordt benadrukt dat thuis de vrouw de scepter zwaait.

3. In 1958 verschijnt onder de titel 'The Suburban Sadness' cen gewijzigde versie van dit artikel in William Dobriners bundel The Suburban Community (1958).

4. Zie Baldassare (1986): pp. vii, 30. Zie voor kritick op Tom Raths rol van exemplarische suburbane forens in Whyte's The Organization Man en Riesmans 'The Suburban Dislocation' onder andere Elizabeth Longs The American Dream and the Popular Novel (1985) en Catherine Jurca's 'The Sanctimonious Suburbanite' (1999).

5. Het essay 'The Myth of Suburbia' verscheen in 1961 in Journal of Social Issues. 'Suburbs, Subcultures, and Styles of Life' is gebaseerd op een paper voor de Washington University Conference on Planning for the Quality of Urban Life in 1965.

6. Een andere klassieke opvatting van de mythe die vergelijkbaar is met die van Berger is te vinden in William Dobriners Class in Suburbia (1963). Overigens hanteert Dobriner niet alleen de term 'myth', maar ook 'legend', 'stereotype' en 'superstition' (zie met name het voorwoord en hoofdstuk i). Douglas Kneeland vat in 'There is No Firm Stereotype' (1974) 'mythe' en 'stereotype' op als synoniemen. Beide staan voor een beeld 'frozen in the American mind (...) - all green velvet lawns and swimming pools and twocar garages viewed through picture windows by practicing Republicans' (Kneeland (1974): p. 272). John Palen onderscheidt in The Suburbs (1995) twee mythen: in de ene staat het homogene, al te hechte gemeenschapsleven centraal, in de andere competitie om status en succes. Bovendien spreekt hij niet alleen van 'mythe' en 'stereotype', maar ook van 'een karikatuur' (zie 
Palen (1995): hoofdstuk 6). Ook over de representatic van Engelseruburbs wordt geschreven in termen van 'mythe': zie bijvoorbeeld Whitetand en Carrs 'England's interwar suburban landscapes: myth and reality' (999).

7. Hoewel Donaldson ingaat op dezelfde misconcepties van subirbia als bijvoorbeeld Berger, wijkt de betekenis die de eerste aan het begrì myth of suburbia toekent af van die in het werk van de tweede. Donaldson/erwijst met 'de mythe' naar de zogenoemde 'myth of the virtuous and heathy yeoman farmer', een ruraal ideaal dat het meest expliciet tot uitdruking is gebracht door Thomas Jefferson. Deze mythe heeft volgens Donatson de vele misconcepties van suburbia waarover hijzelf en Berger sprken tot gevolg. In tegenstelling tot andere commentatoren, verduidelijkt )onaldson, zal hijzelf over die misconcepties niet spreken in termen van mythe', maar zal hij dit begrip reserveren om te verwijzen naar Jeffersons idaal (zie Donaldson (1969): pp. viii, ix).

8. Ook Lynn Spigel wijst in haar bijdrage aan de bundel Visions of uburbia (1997) op de invloed van populaire cultuur op de totstandkoming̨van de unyctic. Uverngens besteedt zij eveneens aandacht aan kritiek die in diverse uitingen van populaire cultuur wordt geleverd op traditionele denkwijzen en levensgewoonten.

9. Vergelijkbaar is Spigels betoog dat het dagelijks leven in de buitenwijk niet los staat van de beelden waarin het wordt gevat. Integendeel. Deze beelden geven daaraan letterlijk vorm: 'the metaphors by which we live our lives often result in the structures we build to contain them. The metaphors of suburban domesticity that circulate in popular culture serve as a foundational myth for the housing policies and community designs in which we live or cannot live' (Spigel (1997): pp. 236-7).

10. Zie voor opmerkingen over het eenzijdige en negatieve denken over de buitenwijk in Nederland bijvoorbeeld Reijndorp, Kompier, Metaal, Nio en Truijens' Buitenwijk (1998), Nio's 'Verhalen uit de buitenwijk' (1999) en Van Rossum, Van Wijken Baljons De stad in uitersten (2001).

11. In 'Realistisch vlagvertoon' wijst filosoof Gerard de Vries op de relatie tussen het spreken in termen van een streven naar een getrouwe representatic van de feiten en de vestigingsstrategie van de sociologic als wetenschappelijke discipline (zie De Vries (1999): pp. 99-101; vergelijk Rein de Wilde's Discipline en legende (1992)). Interessant in dit verband is dat Gans het pleidooi voor accuratesse in The Levittowners (1967) koppelt aan wat hij de taak van de sociologie noemt, namelijk het observeren van wat mensen werkelijk zeggen en doen (zie Gans (1982): p. xviii). In overeenstemming hiermee is Gans' stelling in People and Plans (1968) dat het amateur-sociologie is die in plaats van realiteit mythe biedt (zie Gans (1968): p. 137). Vergelijkbaar is het onderscheid dat Dobriner maakt tussen commentatoren of social impressionists en wetenschappers, en tussen de suburban 'studies' (tussen aanhalingstekens) van de eersten en het onderzock van de laatsten, dat niets minder dan 'the sociological reality of the suburb' in kaart dient te brengen 
(zie Dobriner (1963): pp. 5, 19). Waar Gans en Dobriner het voor de sociologic opnemen, wil James Wunsch iets betekenen voor de geschiedschrijving. In 'The Suburban Cliche' (1995) koppelt hij de eis van accuratesse aan de missie van de historicus (zie Wunsch (1995): pp. 655, 656).

12. Twee varianten van vertekening worden onderscheiden. Volgens de eerste doet de mythe geen recht aan de statische complexiteit van de buitenwijk. Ze ontkent, zo is de gedachtegang, de diversiteit die in cen enkele suburb op een enkel moment valt aan te treffen, zoals ze ook de verschillen tussen diverse buitenwijken op zo'n moment niet tot uitdrukking brengt. De tweede variant betreft de dynamische complexiteit van suburbia. In de mythe, zo luidt de stelling, zijn de vele ontwikkelingen die zich in de loop der jaren in buitenwijken voltrekken onvoldoende of zelfs helemaal niet terug te vinden. Dat beide varianten ook in eén adem worden genoemd, is te zien in Louis Masotti en Jeffrey Haddens inleiding van de bundel Suburbia in Transition (1974).

13. Ik parafraseer hier een typering van Frank Ankersmit van het historisch verhaal (zie Ankersmit (1996a): p. 54).

14. Hiermee neem ik een voorstel over uit Ankersmits De macht van representatie (1996b), namelijk om niet meer te spreken van 'afbeelding', maar van 'verbeelding'. Ankersmit, op zijn beurt, zoekt aansluiting bij de kritiek van met name Ernst Gombrich en Arthur Danto op de afbeeldingstheorie (zie Ankersmit(1996b): hoofdstuk 1).

15. Een tweede suggestie is dat de mythe een stabiel beeld zou inhouden. Dit miskent dat in typeringen van de mythe in de loop der tijd andere accenten worden gelegd. Waar in de jaren vijftig homogeniteit bijvoorbeeld voornamelijk wordt gekoppeld aan conformisme, wordt ze in de jaren tachtig en negentig vooral gepaard aan etnische segregatic.

16. Een klassieke stelling in dit verband is te vinden in Sylvia Fava's artikel 'Suburbanism as a Way of Life': 'There are no grounds for doubting that suburbanism is "a way of life"' as well as an ecological phenomenon' (Fava (1956): p. 37).

17. Zie bijvoorbeeld Gary Cross' 'The suburban weekend' (1997). Cross concentreert zich op het onderscheid tussen werktijd en vrije tijd. Daarbij zoekt hij aansluiting bij Norbert Elias' tijdopvatting in Time (1992). We moeten tijd begrijpen, schrijft Cross, als 'a means of co-ordinating roles in a "social time grid"' (Cross (1997): p. 112). Een minder recent, maar in het veld van suburban studies invloedrijk voorbeeld van deze conceptie van tijd is te vinden in het hoofdstuk 'Time' in Seeley, Sim en Loosley's klassieke studie Crestwood Heights (1956).

18. Het voert hier te ver om in te gaan op de verschillende wijzen waarop in beide onderzoekstradities tijd is geconceptualiseerd. Voor een overzicht van fenomenologische en andere filosofische opvattingen van tijd, zie bijvoorbeeld het eerste en derde deel uit Paul Ricoeurs reeks Time and Narrative (respectievelijk Ricoeur (1984) en (1988)) en J.J.A. Mooijs Tijd en geest (2001). 
Voor een overzicht van sociologische en psychologische tijdsopvattingen, zie bijvoorbeeld Barbara Adams Time and Social Theory (1990). Voor een overzicht van sociologische opvattingen van tijd in relatie met ruimte, zie bijvoorbeeld John Urry's Consuming Places (1995).

19. In Zeit und Kultur (1980) wijst Rudolf Wendorff op psychologisch onderzoek naar de temporele orièntatie van zowel individuen als groepen, waarin onder andere geslacht, leeftijd, opleiding, sociale status, religie en cultuur van belang worden geacht (zie Wendorff (1980): pp. 484-5). Barbara Adam bespreekt kort een aantal voorbeelden van sociologisch onderzock naar temporele oriëntatic, waarin onder andere klasse, ras en beroep centraal staan (zie Adam (199o): pp. 93-6).

20. Wendorff spreekt zowel van tijdperspectief als -horizon (zic Wendorff (1980): pp. 481-6). Hij hanteert de term 'Beziehung', waarmee hij angeeft dat het hier niet eenvoudig gaat om een kijk op tijd, maar om een verhouding tot en betrokkenheid op heden, verleden en toekomst. Bovendien beschouwt hij tijdperspectief en -horizon niet slechts als oriëntaties in de tijd, maar brengt hij beide in verband met levenshouding, gedrag en handelen.

21. In haar voorwoord in de bundel Suburbia Re-examined (1989) wijst architectuurhistorica Barbara Kelly er niet alleen op dat de definitie van 'suburbia' veranderlijk is, maar dat de bruikbaarheid van de term 'suburbia' überhaupt ter discussie staat. Tijdens de Hofstra-conferentic waaruit de bundel is voortgekomen, stond suburbia daarom niet alleen als fysieke ruimte en sociale woonomgeving centraal, maar vooral ook als een intellectueel construct (zie Kelly (1989): p. xv). De sociaal geograaf Van Engelsdorp Gastelaars heeft erop gewezen dat het ook in de Nederlandse situatie lastig is om een definitie te geven van suburbia (zie Van Leeuwen (1993): p. 28).

22. Cursivering in origineel. Waar cursivering van mij is, zal ik dat vermelden.

23. Howard schrijft zelfs: 'out of this joyous union will spring a new hope, a new life, a new civilization'(Howard (1965): p. 48).

24. Donaldson geeft een voorbeeld van een nog hechtere band tussen stad en land. In The Growth of the City in the Nineteenth Century (1900) omschrijft Adna Weber de opkomst van suburbia als 'a complete interpenetration of city and country, a complete fusion of their different modes of life and a combination of the advantages of both, such as no country in the world has ever seen' (zie Donaldson(1968): p. 552).

25. Een verwante typering van suburbs en hun inwoners is te vinden in de klassieker The Suburban Trend (1925) van socioloog Harlan Paul Douglass. 'Man works in the city with half his will and loves it with half his heart. The other half he reserves for the suburbs: but he cannot focus both halves upon either'. De buitenwijk is volgens Douglass geen 'all-sided social unit', maat 'is concerned with part - (...) with not more than half of human interests'. Suburbs, concludeert hij, are a realm of incomplete social relationships 
and limited obligations - a refuge of many half-men, and they half-known men asleep most of the time they are there!' (Douglass (1970): pp. 220, 223). in het recentere The Suburbs stelt John Palen dat ook bewoners zelf zich over hun buitenwijk uitlaten in termen van 'noch-noch' en middle (zie Palen (1995): p. 98). David Hummon stelt in Commonplaces (1990) zelfs dat veel bewoners hun buitenwijk niet als buitenwijk beschouwen. Tegenover uitgesproken opvattingen over stad en small town plaatst Hummon een zwak besef van wat suburbaan is (zie Hummon (1990): hoofdstukken 5 en 7 ).

26. Vergelijkbaar is David Riesmans oordeel in 'The Suburban Sadness'. Stond in de Amerikaanse cultuur voorheen de dichotomic 'pure country versus wicked (but exciting) city' centraal, in de jaren vijftig, betoogt Riesman, domineert the suburban outlook, which homogenizes, without fully integrating, both city and country' (Riesman (1958): p. 39o). Vergelijkbaar is ook John Keats' fictioncle Rolling Knolls: 'neither city nor country, but a combination of the disadvantages of both' (Keats (1957): p. 64). In het algemeen, zo vat William Dobriner het oordeel van commentatoren samen, zou het suburbia ontbreken aan 'both the liberalism and vitality of the city and the unsophisticated simplicity and strength of the rural village' (Dobriner (1963): p. 7). Boomkens typeert ook het Nederlandse suburbia in termen als deze. In het artikel 'Babbelen in het paradijs' (1999) kenmerkt hij het als een middle landscape, ergens tussen stad en natuur in, volgens sommigen het beste van twee werelden, voor anderen een nergensland, een landschap zonder eigenschappen (zie Boomkens (1999): p. 580).

27. Strikt genomen gaat het hier om plaatsen binnen de grenzen van de county waartoe de stad behoort. Als we daarbij echter de Census-definitie van de metropolitan area betrekken, kunnen ook plaatsen daarbuiten als suburb worden aangemerkt. Een voorbeeld van een variant van de Censusdefinitic in een historische studie is te vinden in Robert Fishmans Bourgeois Utopias (1987), waarin de zogenoemde middle-class suburb of privilige waarop Fishman zich concentreert, wordt omschreven als een residentiele gemeenschap voorbij de kern van een grote stad die fysiek is gescheiden van dic stad, maar daarvan economisch, cultureel en commercieel afhankelijk is (zic Fishman (1987): p. 5). Een voorbeeld in de sociologie is Baldassare's opvatting van suburbane gemeenschappen als 'the municipalities and places in metropolitan areas outside of the political boundaries of the large central cities' (Baldassare (1992): p. 476). Een minder recent voorbeeld uit diezelfde discipline is te vinden in de inleiding van Dobriners The Suburban Community. Daarin wordt de volgende werkdefinitie van de suburb voorgesteld: 'those urbanized, residential communities which are outside the corporate limits of a large central city, but which are culturally and economically dependent upon the central city' (Dobriner (1958): p. xvii). Overigens stelt Dobriner vijf jaar later dat deze definitie van de suburb te beperkt is. In Class in Suburbia betoogt hij dat ze geen rekening houdt met wat hij de verstedelijking van de suburban zone noemt. Met name de groeiende economi- 
sche onafhankelijkheid en de toenemende heterogeniteit van de bevolking - zowel qua klasse, als qua etnische en raciale opbouw - zijn daarbij van belang (zie Dobriner (1963): pp. 26-7).

28. In de inleiding van Crabgrass Frontier (1985) somt historicus Kenneth Jackson een aantal kenmerken op die het Amerikaanse suburbia in internationaal perspectief uniek maken. Hij vat vier aspecten in één zin samen: affluent and middle-class Americans live in suburban areas that are far from their work places, in homes that they own, and in the center of yards that by urban standards elsewhere are enormous. This uniqueness thus involves population density, home-ownership, residential status, and journey-to-work' (Jackson (1987): p. 6).

29. Te denken valt aan buitenwijken op verschillende afstanden van een bepaalde stad, met verschillende inwoners, die verschillende relaties onderhouden met het centrum. Te denken valt ook aan buitenwijken rond steden in verschillende regio's. Twee suburbs die in een bepaalde periode even ver van een centrale stad liggen, kunnen behoorlijk verschillen als de ene stad aan de oostkust ligt en de andere aan de westkust. Vergelijken we bijvoorbeeld New York met Los Angeles dan verschillen niet alleen het landschap en het transportnetwerk, maar ook de bevolkingssamenstelling en de sociaal-politieke en economische situatie.

30. In De macht van representatic onderscheidt Ankersmit deze narratieve betekenis van de descriptieve betekenis van afzonderlijke uitspraken over het verleden. Die afzonderlijke uitspraken worden met elkaar in verband gebracht in wat Ankersmit een narratieve substantie noemt. Deze houdt niet eenvoudig een weergave van het verleden in, maar 'een weergave van het verleden onder een bepaald aspect dat door de narratieve substantic wordt vastgelegd'(Ankersmit(1996b): p.131).

31. In sommige teksten wordt benadrukt dat veel trolleylijnen niet primair worden aangelegd om mensen te vervoeren, maar om de bouwgrond in het gebied dat zij doorkruisen winstgevend te maken. Overigens wordt algemeen aangenomen dat de trolley een belangrijke factor is in de ontwikkeling van suburbia. Over het oorzakelijk verband tussen streetcar en buitenwijk verschillen de meningen echter. In sommige teksten geldt het nieuwe vervoermiddel als de oorzaak van de trek naar buiten, in andere is het juist een gevolg.

32. In veel vertellingen levert Los Angeles de voorbeelden van contrasterende buitenwijken van 'de oude' en 'de nieuwe' middenklasse. In de eerste decennia van de twintigste eeuw ontwikkelt L.A. zich geleidelijk tot een suburbane, gedecentraliseerde metropool. In de moeilijk bereikbare heuvels worden exclusieve enclaves voor de allerrijksten gebouwd, de uitgestrekte vlakte wordt opgeslokt door tract housing voor de snel groeiende middenlaag.

33. Zie bijvoorbeeld Harris en Lewis' 'The Geography of North American Cities and Suburbs, 1900-1950'(2001). 
34. Daarbij valt op dat vrijwel altijd wetenschap als uitgangspunt fungeert en literatuur wordt opgevoerd als aanvulling daarop. Die aanvulling kan zowel een toevoeging van nieuwe inzichten inhouden als een correctic.

35. Zie voor kritiek op Haraway's benadering van literatuur Stine Jensens Waarom vrouwen van apen houden (2002).

36. Zie Rorty's analyses van de personages Humbert Humbert uit Nabokovs Lolita en O'Brien en Winston Smith uit Orwells 1984 in Contingency, Irony and Solidarity (1989). Zie daarnaast Rorty's opmerkingen over Dickens' werk in het essay 'Heidegger, Kundera and Dickens' in Essays on Heidegger and Others (1991).

37. Zie Nussbaums The Fragility of Goodness (1986), Love's Knowledge (1990) en 'Fincly Aware and Richly Responsible' (1987).

38. Zie naast 'Forms of Time and of the Chronotope in the Novel' (1998b) ook Bakhtins 'The Bildungsroman and Its Significance in the History of Realism' (1986) en 'Problems of Dostoevsky's Poetics' (1994). Zie naast Morsons 'Bakhtin, Genres and Temporality' (1991) en Namative and Freedom (1994) ook zijn Mikhail Bakhtin: Creation of a Prosaics (1992) en 'Strange Synchronies and Surplus Possibilities'(1993).

39. De Vries maakt gebruik van Mooijs Tekst en Lezer (1979). In Idee en verbeelding (1981) zet Mooij het een en ander uiteen over de problematick van het streven binnen de literatuur-en wetenschapstheorie naar bepaling van hun beider objectgebied. Mooij schetst een ontwikkeling van toenemende scepsis omtrent de mogelijkheid vast te stellen wat we precies onder 'literariteit' en 'wetenschappelijkheid' moeten verstaan (zic Mooij (1981): hoofdstuk6).

40. Een verwante opvatting over literaire en wetenschappelijke teksten, maar één die niet zoals die van De Vries is geschoeid op een pragmatistische leest, wordt verdedigd door George Levine. In het essay 'One Culture: Science and Literature' betoogt hij dat literatuur en wetenschap 'whatever else they may be, are modes of discourse, neither of which is privileged except by the conventions of the cultures in which they are embedded'. Zo opgevat, vervolgt Levine, is een onderscheid a priori tussen beide soorten teksten nauwelijks te maken. In elk geval kunnen we niet meer terugvallen op klassieke dichotomieèn als 'the world of value and the world of fact, the subjective and the objective, or the intuitive and the inductive', zo citeert hij Thomas Kuhn (Levine (1987): pp. 3,4).

41. Op dit punt heeft Ido Weijers' aanpak in Terug naar het behouden huis (1991) mij geìnspireerd. In zijn boek over de relatie tussen Nederlandse romanschrijvers en wetenschappers in de jaren vijftig neemt Weijers afstand van een internalistische geschiedschrijving die wetenschap en literatuur uitsluitend als een wetenschaps- of literatuurinterne ontwikkeling presenteert. Overtuigend verdedigt hij de stelling dat het zinvol is om constructies van maatschappelijke problemen in teksten uit de ene discipline te bezien in de context van constructies in teksten uit de andere (zie Weijers 
(1991): pp. 10, 115-6). Net als Weijers' opvattingen maken ook die va Levine deel uit van een tendens tot historisering en contextualisering varwetenschappelijk onderzoek. Nadat hij concrete voorbeelden heeft gegeen van het soort studies dat deze tendens oplevert, schrijft Levine: 'Onc one is committed to the view that science is not so clearly separable fom the human sciences (...) or from other humanist enterprises, history oscience begins to blur in with social history. Literature becomes part of thenistory of science. Science is reflected in literature. And the tools of literay criticism become instruments in the understanding of scientific disourse' (Levine (1987): p. 22).

42. Het hoofdpersonage mag dan een onnozelaar zijn die zich op dsuburbane woningmarkt belachelijk maakt, als instrument in zijn subuiakritiek, tekent Keats aan, 'Drone has served us well'(Keats (1957): p. 164)

43. Meinig citeert hier uit Daniel J. Elazars Cities of the Prairie, The Metropolitan Frontier and American Politics (1970).

44. In het essay 'The Beholding Eye' (1979a) geeft Meinig voorbeelden van interpretaties van het fysieke landschap als uitdrukking van een ideaal en als probleem. Spitsen we Meinigs benadering toe op suburbia, dan kunnen we het landschap bijvoorbeeld opvatten als uiting van vrijheid en een geloof in vooruitgang, maar evenzeer als een vorm van ongebreidelde sprawl die resulteert in verkeerscongestic.

45. Om de verknooptheid van opvattingen over een bepaalde plaats met die over bijvoorbeeld sociale verhoudingen en gedrag uit te drukken, zijn in het landschapsonderzoek verwante termen gemunt als landscape of the mind en cognitive landscape. Zie voor een korte uiteenzetting hiervan bijvoorbeeld Jeremy Korrs 'A Proposed Model for Cultural Landscape Study' (1997).

46. Deze 'plaatsbeelden' samen vormen in Shields' terminologie een zogenaamde 'plaatsmythe'. Om verwarring met het begrip 'suburbane mythe' te voorkomen, zal ik deze term niet gebruiken. Bovendien zal ik in tegenstelling tot Shields niet spreken van een onderscheid tussen een kern (van relatief stabiele beelden) en een periferie (van relatief vluchtige beelden), maar van een stelsel van vertelstructuren en motieven die in verschillende gedaanten en verschillende combinaties kunnen opduiken.

47. Zoals Baldassare het beeld van de fifties-suburb typeert als een stereotype, benadrukt ook Shields dat plaatsbeelden lang niet altijd even subtiel zijn. Hij wijst erop dat ze onder andere totstandkomen door oversimplificatic (reductic tot één kenmerk), door stereotypering (versterking van een of meerdere kenmerken) en doordat een bepaalde plek een label krijgt opgeplakt waarvan het niet eenvoudig meer afkomt.

48. Shields staat in een traditic waarin geografie een kwestie is van relatic 
tussen plaatsen en verplaatsingen in de ruimte. Een term als social spatialisation en het Lefebvreaanse onderscheid tussen 'ruimtelijke praktijken', 'de representatic van ruimte' en 'de ruimte van representatie' kunnen daarvan getuigen. Mijn doel is niet om een kritiek te formuleren op dit perspectief en het daarop toegesneden instrumentarium. Wel wil ik erop wijzen dat in een dergelijke traditie, waarin erg wordt gehecht aan wat wel het lezen van de omgeving' wordt genoemd, tijd sterk onderbelicht blijft en soms zelfs zo goed als genegeerd wordt. Ook auteurs die zich niet zoals ik op de rol van tijd concentreren, hebben kritiek geuit op deze sterk visueel-ruimtelijke benadering van de gebouwde omgeving. In Building the Workingman's Paradise (1995) kritiseert Margaret Crawford bijvoorbeeld wat zij 'de blik van de toerist' noemt. Het lezen van de zichtbare omgeving heeft volgens haar geleid tot een architectural fallacy (zie Crawford (1995); p. 8). In Making a Middle Landscape (1991) waarschuwt Peter Rowe voor het verloren gaan van een deel van de complexiteit en de nuances van sociale structuren, als uit de ruimtelijke structuur de sociale organisatie wordt afgeleid (zie Rowe (1991): hoofdstuk 2).

49. Zie bijvoorbeeld Peter Mullers Contemporary Suburban America (1981): pp. 20-1. Beroemd is vooral het hoofdstuk 'What is an American' in Crèvecoeurs Letters From an American Farmer (1782).

50. In cen van zijn tirades gericht tegen dit aloude Amerikaanse rurale ideaal verbaast Donaldson zich erover hoe zo'n ogenschijnlijk tegenstrijdig bestaan - 'the myth of the sturdy yeoman farmer plowing his own acres in self-sufficient independence, yet somehow part of a rural community' cen natie zo lang in zijn ban kan houden (Donaldson (1968): p. 564).

51. De gedachte dat de grote, lege ruimte Amerikanen westwaarts lokt en dat deze beweging de belangrijkste is in de vorming van de Amerikaanse samenleving en cultuur staat bekend als de frontier-hypothese. De invloedrijkste tekst waarin deze wordt verdedigd, is 'The Significance of the Frontier in American History' (1893) van de historicus Frederick Jackson Turner.

52. Downing geciteerd in Stilgoe(1988): p. 93.

53. Er is discussie geweest over de vraag of deze groep een 'sociale klasse' of slechts een 'stratum' moet worden genoemd. Sies stelt dat ze alle kenmerken van een sociale klasse heeft - een uniforme relatie met productiemiddelen, eenzelfde functie in de samenleving, een antagonistische relatie met andere klassen en een onderscheiden, gedeelde cultuur. Omdat ze echter slechts tussen ongeveer 1870 en 1920 op basis van deze criteria als een aparte groep kan worden onderscheiden, kiest Sies voor 'stratum'.

54. Interessant is in dit verband Crawfords typering van het gedachtegoed van diverse hoofdrolspelers in de hervormingsbeweging als 'een conservatieve interpretatie van progressieve idealen'. Belangrijke voorbeelden die in Building the Workingman's Paradise worden uitgewerkt, zijn Indian Hill, Massachusetts en Chicopee, Georgia (zie Crawford (1995): hoofdstukken 6 en 9). 55. Op het eerste gezicht lijkt deze nieuwgemunte term te leiden tot 
begripsverwarring. Dat blijkt echter mee te vallen als we nader bekijken wat Berger ermee wil uitdrukken - en vooral welke termen hij ermee weet te omzeilen. Waar het hem om gaat, is uitdrukken dat de upper-lower class minder gemeen heeft met lower-lower class dan met de lower-middle class en dat de lower-middle class meer gemeen heeft met de upper-lower class dan met de upper-middle class. Daarom beschouwt Berger de upper-lower en lower-middle class wat betreft levensstijl als cen enkel stratum (waarmee hij overigens niet beweert dat daarbinnen geen fijnere gradaties te onderscheiden zijn) (zie Berger (1968): p. 96).

56. Vergelijkbaar is Kelly's typering van de vrijstaande suburbane woning als het belangrijkste embleem van de Amerikaanse droom (zie Kelly (1993): p.12).

57. Dat een buitenwijk ondanks sterke groei haar oorspronkelijke sociale karakter behoudt, heeft Reynolds Farley suburban persistence genoemd (zie Farley (1964)).

58. Zie voor een voorbeeld van deze gedachtegang Muller(1981): hoofdstuk 2. 59. In consumpticonderzoek wordt overigens kritiek geuit op Veblens theorie. Met haar eenzijdige aandacht voor sociale status zou zij andere betekenissen van consumptie uit het oog verliezen. Bovendien zou competitiedrang tussen mensen met een gelijke positie op de ladder worden verward met het streven naar een hogere sociale status (zie bijvoorbeeld Colin Campbells The Romantic Ethic and the Spirit of Modern Consumerism (1989) en Daniel Millers Material Culture and Mass Consumption (1991)).

6o. Meestal wordt het consumptieartikel beschouwd als een uitdrukking van de persoonlijke levensstijl of status. In 'The World in a Shopping Mall' gaat Margaret Crawford een stap verder. Het ding maakt stijl of status niet alleen zichtbaar, het definieert deze zelfs (zie Crawford (1994): pp. 11-2).

61. Vergelijkbare passages zijn bijvoorbeeld te vinden in Crestwood Heights (zie het hoofdstuk 'Shelter').

62. Ik parafraseer hier Jacksons omschrijving van de belofte die het suburbane ideaal volgens hem inhoudt (zie Jackson (1987): p. 72).

63. Een aantal sociaal- en geesteswetenschappelijke studies uit de jaren tachtig die belangrijke bijdragen zijn gebleken aan het denken over de buitenwijk, zal als uitgangspunt fungeren. Daarin worden niet alleen benaderingen van suburbia bijeengebracht die tot dan toe invloedrijk waren, maar ook lijnen uitgezet die in de jaren negentig en aan het begin van de nieuwe eeuw worden doorgetrokken.

64. Fishman citeert ook uit Sesame and Lilies (1865) van de romantisch denker John Ruskin. Hierin is het huis 'the place of Peace, (...) a sacred place, a vestal temple'. Het is een schuilplaats die beschermt tegen 'the anxieties of the outer life (...), the inconsistently-minded, unknown, unloved, or hostile society of the outside world'(Ruskin geciteerd in Fishman (1987): p. 101).

65. Het gaat volgens Fishman - en velen met hem - met name om het geluk van de kinderen die God an hun ouders heeft toevertrouwd (zie ibid: p. 
58). Het streven naar welzijn van kinderen - zowel het slagen daarvan als het mislukken - is een van de vaakst terugkerende thema's in het suburbiadiscours.

66. Fishman ziet in het evangelische ideaal van de bourgeois de beslissende duw in de richting van de scheiding tussen wonen in de buitenwijk en werken in de stad. Volgens de evangelisten, betoogt Fishman bovendien, dient tussen de activiteiten in beide domeinen een evenwichtige relatic te bestaan. Volgens de historicus passen niet alleen het gezinsleven thuis, maar ook de werkzaamheden in de stad in een coherent stelsel van puriteinse waarden. Thornton schrijft bijvoorbeeld niet alleen over familic en emotie, maar ook over de deugden en beloningen van werk. En Wilberforce pleit voor een combinatie van ijver, soberheid, punctualiteit, beheersing. gezondheid en regelmaat.

67. Kenneth Jackson verwijst bijvoorbeeld naar de visie die dominee William Eliot in 1853 uiteenzet (zie Jackson (1987): p. 48).

68. Wright spreekt van een cultus van het deugdelijke gezinsleven, georganiseerd rond wat zij 'het arcadische huis' noemt. Daarin zijn 'the good family' en 'the suburban home' bijna inwisselbare concepten.

69. Ook in Donaldsons 'City and Country' en The Suburban Myth fungeert het paradijs als contrapunt. Het rurale paradijs, of 'the Jeffersonian paradise regained', zoals Donaldson het graag formuleert, geldt er vanwege de veel te hoge verwachtingen die het oproept als de bron van alle kwaad. Het ligt aan de basis van de mythe waartegen Donaldson ten strijde trekt.

70. In Contemporary Suburban America besteedt Muller aandacht aan het idee van de arcadische buitenwijk (zie Muller (1981): hoofdstuk 2). In Bunce' The Countryside Ideal wordt niet alleen gesproken van een arcadisch ideaal, maar evenzeer van arcadisch escapisme (zie Bunce (1994): hoofdstuk 5).

71. In Expanding the American Dream laat Kelly bewoners zelf aan het woord. Terugblikkend op hun beginjaren in Levittown, kwalificeren ook zij hun wijk als een paradijs (zie Kelly (1993): p. 149).

72. Zoals we in hoofdstuk 4 zullen zien, wordt ook het Tarbox in John Updike's Couples (1968) nadrukkelijk als een pastoraal plaatsje geïntroduceerd, terwijl de woningen van twee hoofdpersonages de hof van Eden belichamen. In hoofdstuk 6 staat Douglas Couplands Brentwood centraal: naast een groene hemel en een utopische plek 'the dream of American Arcadian living' (Coupland (1997): p. 163).

73. Rowe citeert hier Barbara Novaks 'The Double-Edged Ax' (zie Rowe (1991): p. 222).

74. Hieraan voegt Jackson nog toe dat buitenwijken die vroeger bijvoorbeeld 'West Chicago' heetten, nu met hun naam een landelijke sfeer oproepen. Alleen al rond Chicago liggen vierentwintig gemeenschappen die 'Park' of 'Forest' in hun naam hebben, inclusief een Park Forest en Forest Park. Ook straatnamen in suburbia moeten bucolische associaties oproepen. Woorden als 'rolling', 'fields', 'lake', 'view', 'hills', 'timber', 'roaring', 
'green' en 'forest' doen het goed in de buitenwijk. Bovendien gaan zij niet vooraf aan 'street', maar aan 'lane', 'cove', 'road', 'way', 'fairway', of 'terrace' (zie Jackson(1987): pp. 272-3).

75. Deze maakt deel uit van een verklaring van suburbanisatie in termen van een sociale beweging. Dobriner plaatst deze tegenover verklaringen in termen van technologische, economische en institutionele processen en verklaringen waarin individuele doelstellingen en waarden centraal staan. 76. Als toonbeeld hiervan wordt meestal het pittoreske Llewellyn Park in New Jersey genoemd. Dit middennegentiende-eeuwse geesteskind van de vermogende Llewellyn S. Haskell wordt beschouwd als Amerika's eerste volledig geplande suburb. In sommige geschiedenissen wordt in dit verband benadrukt dat Haskell een perfectionist is. Het perfectionisme is een religieuze stroming die verwant is aan het puriteinse denken, maar daarvan op ten minste één fundamenteel punt afwijkt. Niet de doctrine van het determinisme staat centraal, maar de mogelijkheid zonden te corrigeren. Geloofd wordt dat de zondaar, mits voldoende ijverig, zijn leven kan beteren. De gedachte is dat een groene suburbane woonomgeving hem hierin kan steunen. In de buitenwijk komt als het ware de hemel al op aarde binnen handbereik.

77. Deze kritiek is in de meeste verhandelingen over suburbia terug te vinden. Zie voor een bondig commentaar de conclusie uit Crawfords Building the Workingman's Paradise. Een hiermee samenhangende typering van het pittoreske is die van het landschap als een plek die geheel en al in het teken staat van consumptic (zie bijvoorbeeld Raymond Williams' The Country and the City (1973): hoofdstuk 12).

78. Stern noemt bijvoorbeeld de keuze voor bepaalde stenen en stucwerk, de stormlamp in het raam en het wagenwiel in de voortuin (zie Stern (1986): p. 85).

79. Paradigmatisch in Sterns betoog is de rol van Thomas Jefferson. Hij bouwt het eerste Amerikaanse droomhuis: Monticello in Virginia. Het is zowel in esthetisch als filosofisch opzicht exemplarisch voor een nieuwe natie. Het huis demonstreert dat in Arcadie klassieke schoonheid kan worden gecombineerd met de praktische instelling van de Nieuwe Wereld, stelt Stern. Met de bouw van Monticello legt Jefferson de basis voor een Amerikaanse traditie die tot op heden standhoudt. De bezigheden van de doe-het-zelver in en rond het eigen huis beschouwt Stern als een herhaling van Jeffersons onderneming.

8o. Een aan Sterns betoog verwante analyse is die van Garreau in Edge City (1991). Met Leo Marx onderscheidt Garreau twee natuurbeelden die vanaf de eerste jaren van de kolonisatie van Amerika met elkaar strijden om de voorrang in de nationale verbeelding. Het eerste is dat van de hof van Eden zoals verwoord door Arthur Barlowe in zijn beschrijving van Virginia in 1584. Het tweede is dat van de verschrikkelijke wildernis die de Pilgrims onder leiding van William Bradford in 1620 in Massachusetts aantreffen. 
Elk vormt een 'root metaphor' waarin een specifieke notie van Amerika's bestemming gestalte krijgt. In het eerste beeld heeft het landschap cen inherente waarde. Die heeft het altijd gehad. In het tweede vergt het landschap menselijk ingrijpen. Zonder dit zal het waardeloos blijven. De keuze tussen beide wordt volgens Garreau in Amerika steeds opnieuw gemaakt. Dat gold voor de eerste kolonisten en het geldt nog steeds in hedendaagse edge cities (zic Garreau (1992): hoofdstuk 1). Kunstler onderscheidt in The Geography of Nowhere (1993) nog een derde beeld van de natuur die de eerste settlers aantreffen. De puriteinen die met de Mayflower aankomen in Plymouth Harbor identificeren zich met het volk van Israel, waardoor ze volgens Kunstler in staat zijn de wildernis te beschouwen als het beloofde land van Kanaăn. Dit land biedt hoop. Het kan worden ontwikkeld tot een land van melk en honing (zie Kunstier (1994): hoofdstuk 2).

81. 'Such is the issue of commuting urban trouble,' luidt Stilgoe's conclusie. 'It is perhaps a key issue of American civilization, simply because it grows out of the national religious taproot, out of the great immigration and westering enterprises, and because it continues to haunt public discourse about contemporary urban problems'(Stilgoc (1988): p.9).

82. Naast de rugged individual en de pioneer vertegenwoordigen meestal ook de sturdy yeoman en de self-made man dit autonome en moedige individu. Henry Nash Smith spreekt in Virgin Land (1950) van 'the courageous, virile, and determined stand of the individual as an individual' (Smith (1978): p. 100).

83. Zowel in Jacksons Crabgrass Frontier als in Thomas' The United States of Suburbia (1998) wordt in dit verband Thomas Jefferson geciteerd: 'I view largecities as pestilential to the morals, the health, and the liberties of man'. In Meinigs 'Symbolic Landscapes' (1979b) heten Amerikanen zelfs 'escapist at heart'. Het dorp, het kleine provinciestadje en de suburb vormen zijn symbolische landschap. De stad ontbreekt daarin.

84. In hoofdstuk 6 zal ik laten zien dat het toekomstperspectief van Couplands Brentwoodians wordt beheerst door de angst te worden meegesleurd in de val van Los Angeles.

85. Wie met 'onze' wordt bedoeld, is in Rowe's betoog niet duidelijk. Rowe baseert zich onder andere op William Sharpe en Leonard Wallocks bundel Visions of the Modern City: Essays in History, Art and Literature (1987) en Carl Schorske's 'The Idea of the City in European Thought: Voltaire to Spengler', een bijdrage aan de bundel The Historian and the City (1963).

86. Zie bijvoorbeeld Harris en Lewis' historisch-geografische 'Constructing a Fault(y) Zone' (1998) en 'The Geography of North American Cities and Suburbs, 1900-1950' (2001), Fishmans stadshistorische 'The Post-War American Suburb' (1988) en 'Die neue Stadt des 20. Jahrhunderts' (1994), Sies' 'North American Suburbs, 1880-1950' (2001), Dobriners sociologische Class in Suburbia (1963), Wunsch' sociaal-historische 'The Suburban Cliche' (1995) en, in Nederland, het interdisciplinaire Buitenwijk (Reijndorp et al. (1998)). 
Interessant is ook Gerard de Vries' filosofische kritiek op de sociologische tegenstelling tussen dorpse gemeenschapszin en de mentaliteit die in een stedelijk kader tot ontwikkeling zou komen (zie De Vries (1999): pp. 199213). Hij spreekt van een ontwikkelingsperspectief waarin de route van meet af aan vast ligt. Eerst wordt het dorp op het doek geschilderd, daarna de stad, waarbij deze laatste wordt gekarakteriseerd in termen van wat zij niet meer is: het dorp. Eenzelfde beweging kenmerkt in veel gevallen het denken over de buitenwijk. Is de stad het 'niet-dorpse', dan is de buitenwijk het 'niet-stedelijke'.

87. Wood specificeert niet op wie 'our' doelt.

88. Mulvey gaat specifiek in op het werk van de Amerikaanse fotografe Cindy Sherman. Fifties-ness is een kwaliteit van haar foto's, betoogt ze. Evocatic van het decennium is daarin belangrijker dan verwijzing naar historische referenten.

89. Zoals vaker in het denken over de buitenwijk staat de man centraal. Meer dan van vrouwen, wordt van de man autonomie, individualiteit en initiatief verwacht.

9o. Zowel de tegenstelling tussen de klassieke model-Amerikaan en de werknemer uit de nieuwe middenklasse als de formulering in termen van een object waarmee wordt gesold, roept Mills' White Collar (1951) in herinnering.

91. Whyte hanteert Park Forest als het vergrootglas waarvoor Wood waarschuwt (zie hoofdstuk 2 voor opmerkingen hierover): zie Whyte (1963b): p. 305 .

92. Ook Whyte stelt dat hij niet uit is op veroordeling van de massamens, ranch wagons, televisietoestellen en grijze flanellen pakken (zie ibid: p. 15). Hij lijkt zich echter minder goed dan Riesman te kunnen beheersen. Met name in de inleiding van 'The Transients' (1953) en de conclusie van The Organization Man (1956) maken zowel beeldspraak als woordkeus zijn analyse tot een openlijke aanval, waarin superioriteit, walging en medelijden om de voorrang strijden.

93. Ook Margaret Mead spreekt van gevangenschap in de eigen suburbane woning. In tegenstelling tot Riesman echter, benadrukt ze de keuzevrijheid van gezinsleden: 'The clutter and closeness of the living room. the whole family around the table, the whole family plus the dog in the 5-passenger car - all these represent choices on the part of individual members of the family to be with everyone else - as they are a good part of the time' (Mead (1972): p. 21; oorspronkelijk verscheen het stuk in 1962 als een rapport over recreatie buitenshuis).

94. Op een belangrijk punt verschilt Dobriners opmerking van die van 
Riesman. Riesman benadrukt dat zijn karaktertypen niet het resultaat zijn van empirisch onderzoek, maar dit juist helpen organiseren. Dobriner is minder eenduidig. Ook hij vat het ideaaltype op als een construct dat helpt conceptualiseren, maar suggereert desalniettemin een empirische basis. Het model is een door de onderzoeker geintensiveerde vorm van de werkelijkheid, stelt hij - 'it represents the furthermost logical extension and summation of reality as we know it' (Dobriner (1963): p. 104). Meer dan Riesman bedient Dobriner zich van een - in termen van hoofdstuk 1 uit dit proefschrift-realistisch vocabulaire.

95. Naast realistische beelden kent deze impressie ook evocatieve, poetisch aandoende passages. Het verschil is subtiel. Een zin als 'The house is dark and the moonlight bounces starkly off the uncurtained windows' (ibid: p. 125) kan een waarneming van de aanwezige getuige suggereren. Evocaticver is de volgende zin: 'To the west, beyond the spidery water tower, over the low horizon, are the eternal lights of New York City reaching up into the summer sky, eating the stars' (ibid: p. 126).

96. Interessant is in dit verband de verschuiving van tegenwoordige naar toekomende tijd. 'It's a hell of a day - the kids are crying, Dot is half sick with exhaustion,' lezen we aan het begin van de passage. 'But soon,' luidt het vervolg, "because M-12 is a "happy" court, the neighbours will come over (...) (Whyte (1963b): p. 263). Zij zullen zich voorstellen, meehelpen uitpakken en eten klaarmaken. Daarmee wordt de registratie een projectic van gebeurtenissen die nog moeten plaatshebben, waardoor de beschrijving van de aankomst van dit specifieke stel verandert in een impressie van hoe het er volgens Whyte in Park Forest altijd aan toegaat.

97. Een recent voorbeeld is de inleiding van Suburban Nation (2000). Daarin wordt de lezer zelf opgevoerd als hoofdpersonage in een 'typisch' suburbaan tafereel. 'You're stuck in traffic again. As you creep along a highway that was widened just three years ago, you pass that awfull new billboard: COMING SOON: NEW HOMEs! Already the bulldozers are plowing down pine trees, and a thin layer of mud is oozing onto the roadway. How could this be happening? (...) These one hundred acres, where you hiked and sledded as a child, are now zoned for single-family housing' (Duany et al. (2001): p. ix). Als lezer worden we aangesproken als ervaringsdeskundige, waarbij ons zowel ervaringen als gevoelens worden aangemeten. $\mathrm{Er}$ is letterlijk sprake van stemmingmakerij. We staan voor de zoveelste keer in de file en zien dat de natuur wordt opgeslokt door suburbane uitbreiding. Het is niet alleen jeugdsentiment dat ons van slag brengt, zo wordt verderop duidelijk gemaakt, maar vooral ook het besef dat wat wordt gebouwd, verschrikkelijk zal zijn. Dat is tot nog toe immers altijd het geval geweest, weten we uit ervaring (zie ibid: p. x). Op de gevoelens die deze inleiding opwekt, speelt de rest van het boek in door een alternatieve woonomgeving voor te stellen: de traditional neighborhood, sterk verwant aan de Pedestrian Pocket, een ontwerpconcept dat vaak in één adem wordt genoemd met de stroming New 
Urbanism (zie bijvoorbeeld Peter Calthorpe's The Next American Metropolis (1993) en Peter Katz' The New Urbanism (1994)). Suburban Nation is daarmee een fraai staaltje suburbiakritiek. De voorstelling van de suburbane sprawl waartegen het ageert, is effectief. Het schrikbeeld bestaat onder meer uit te brede wegen zonder stoep, beheerst door garagedeuren of rijen pretentieuze McMansions. Je zult er niet welkom zijn, krijgt de lezer te horen, waaraan onmiddellijk wordt toegevoegd dat je in dat monotone landschap toch niets te zoeken hebt. Ondertussen zullen wegen verder verstopt raken en zullen nieuwkomers ervoor zorgen dat jouw Amerikaanse droom onmogelijk nog kan uitkomen. Je bent tegen groei, lezen we. Je vindt dat het je be staan aantast en je hebt daarin gelijk. De laatste vijftig jaar zijn er voornamelijk plaatsen uit de grond gestampt waar we onmogelijk om kunnen geven: 'gemeenschappen' zonder gemeenschap, winkelketens in grote dozen, omringd door onmetelijke, afzichtelijke parkeerterreinen en antiseptische kantorencomplexen (zie ibid). Hoe kunnen we op dit suburbia geen kritiek hebben, gaat de lezer zich afvragen. Het wordt zodanig voorgesteld dat het alternatief nog voordat het is geïntroduceerd een verademing lijkt.

98. Ze maken deel uit van de wereld van de schrijver. In het verlengde ervan presenteert Keats na afloop van zijn 'roman' een lijst artikelen die het kader waarin we de vertelling van de Drones dienen te begrijpen, verder verstevigt.

99. De rest van de riedel is bekend: uniforme huizen, buren met dezelfde leeftijd, hetzelfde inkomen en aantal kinderen, dezelfde gewoonten, bezittingen en problemen en misschien zelfs dezelfde bloedgroep.

10o. Het enige waaraan Mary haar eigen huis herkent, is 'the black 13 on the warped white doorframe'. In een gotisch aandoend beeld krijgt Mary's sombere bestaan een extra onheilspellend karakter.

101. Gedurende het verhaal leest Arthur het in gedeelten door. We lezen als het ware met hem mee. Aan het begin van de meeste hoofdstukken en soms aan het eind zijn korte passages afgedrukt. Door een afwijkende lettergrootte en gescheiden door een witregel onderscheiden deze zich van de hoofdvertelling.

102. Cameron gooit Mills' nadruk op het kleingeestige karakter van het middenklassebestaan, Whyte's aandacht voor het overspannen sociale leven en Riesmans opmerkingen over het leven thuis op een hoop.

103. Ook in het kritische The Split-Level Trap (Gordon et al. (1960)) wordt suburbia - of disturbia zoals het in dit boek heet - neergezet als een mierenhoop (zie Gordon et al.(1961): p. 30).

104. Yates staat in de traditic van het Amerikaanse realisme waartoe ook John Cheever en John Updike worden gerekend, auteurs die we in hoofdstuk 4 zullen tegenkomen. Hij geldt bovendien als inspiratiebron voor Raymond Carver, die in hoofdstuk 5 kort de revue zal passeren (zie bijvoorbeeld Hans Bertens en Theo D'haens De geschiedenis van de Amerikaanse literatuur(1983)en Jan Donkers 'Ja hoor, ze houden wel van me'(2001). 
105. Andere belangrijke focalisatoren zijn de verteller, April, vriend Shep Campbell en Mrs. Givings, de makelaar die de Wheelers het huis aan Revolutionary Road heeft verkocht.

106. Met name Milly belichaamt de stereotiepe conformist. Veel verder dan 'oh, that's so true' komt zij in gesprekken niet (zie bijvoorbeeld Yates (2001): pp. 60, 66).

107. Als voorbeeld van consumptiedrift in een fictioneel verhaal een citaat uit The Crack in the Picture Window (1956). Keats' personages willen van alles: 'new drapes, rugs, lamps, and gadgets, gadgets, gadgets - led, of course, by that be-all, end-all gadget of our time, the automobile' (Keats (1957): p. 66). 108. Zo is volgens Whyte bijvoorbeeld niet zozeer 'keeping up', als wel 'keeping down with the Joneses' en niet 'conspicuous' maar juist 'inconspicuous consumption' de norm (zie Whyte (1963b): pp. 289-92).

109. Mills koppelt identiteitsverlies door consumptie aan gebrek aan persoonlijkheid op het werk. 'Each day men sell little pieces of themselves in order to try to buy them back each night and week end with the coin of "fun"'(Mills(1977): p. 237).

uo. Hedonisme staat bij Mills en Whyte lijnrecht tegenover de Protestant Ethic, zowel wat betreft handelen als temporele orięntatic. Genieten betekent een gebrek aan persoonlijke onthouding. Gerichtheid op het nu, op momentane bevrediging, is een onvermogen om zaken in het licht van de ceuwigheid te bezien.

11. Peter Lunt en Sonia Livingstone wijzen er in Mass Consumption and Personal ldentity (1992) op dat commercielle producten naast de individuele identiteit ook een 'ideaal zelf' kunnen uitdrukken. De aanschaf van een auto, bijvoorbeeld, geeft dan niet alleen blijk van de levensstijl op het moment van aanschaf, maar ook van een abstracter waardering van individualiteit, vrijheid en onafhankelijkheid als zodanig.

112. Beide functies van consumptiegoederen komen ook tot uitdrukking in Csikszentmihalyi en Rochberg-Haltons The Meaning of Things (1981), een etnografische studie naar gezinnen in Chicago.

113. Het zijn de kleine verschillen die ertoe doen. In dit opzicht sluit Hine's betoog aan bij dat van Whyte (zie Whyte (1963b): p. 289).

114. Een tussenoplossing is het symbolische hek: te kort om als afscherming te functioneren, maar voldoende zichtbaar om een afscheiding te suggereren.

115. Meer in het algemeen stelt Hine dat Populuxe-producten nieuwe suburbanisanten helpen een leven te begrijpen waarop ze onmogelijk voorbereid kunnen zijn (zie Hine (1999); pp. 33-6, 171). In 'Tupperware: Suburbia, sociality and mass consumption' (1997) wijst ook Alison Clarke op de sociale functie van de kunststofbakjes in de buitenwijk.

116. Een retorisch effect van 'het raamwerk' is de suggestic van bouwactiviteit. Het doet denken aan de steigers rond een huis tijdens de constructic. In Picture Windows (2000) worden huiseigenaren ook in dit soort termen opge- 
voerd. Bovendien is het huis daarin een 'leeg doek', waarmee en indruk van creativiteit ontstaat (zie Baxandall en Ewen (2000): p. 164). P Thomas' The United States of Suburbia (1998) draagt een anekdote bij aan de ndruk van de hermodelleringsdrift van bewoners. In 1996 trekken curatoren van het Smithsonian Institution - dat allerlei typen Americana verzanclt - naar Levittown, op zoek naar een souvenir uit de beginperiode van midern suburbia. Ze vertrekken met lege handen. Er is geen huis te vindet dat in de loop der tijd niet is aangepast aan de individuele wensen van bevoners (zie Thomas (1998): pp. 135-6).

117. In Picture Windows gaat de aandacht voornamelijk uit naar ommunity building door vrouwen - 'women who were at first lost in this stratge world, but who then remade it' (Baxandall en Ewen(2000): p. 157).

118. Interessant is ook Hine's aandacht voor het verschil in verva'gingstijd van de dingen in huis. In de woonkamer blijven meubels gemiddæld twalf jaar staan, in de keuken is de cyclus veel korter - 'features were all' (Hine (1999): p. 77).

119. Naast Stern (1986): hoofdstuk 3, Rowe (1991): hoofdstukken 2 en 7 en Jackson (1987): hoofdstuk 3 zijn ook Robert Venturi, Denise Scott ${ }^{B}$ rown en Steven Izenours Signs of Life (1976) en Constance Perins Everything in Its Place

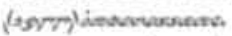

120. Om te benadrukken dat suburbanisatie niet het onvermijdelijke lot van de middenklasse is, maar een bewuste keuze, vergelijkt Fishman de Verenigde Staten met Frankrijk. In tegenstelling tot haar Angelsaksische tegenhanger, betoogt hij, kiest de Franse burgerij in de negentiende eeuw voor destad.

121. Sies benadrukt bovendien dat elk aspect van het ontwerp vooraf in samenwerking met experts wordt uiteengezet. Zelfs als er geen formeel, schriftelijk plan bestaat, betoogt Sies, is de suburb het resultaat van doelbewuste en systematische besluitvorming (zie Sies (1987): p. 91 en noot 18, pp. 109-10).

122. Interessant is bovendien dat Fishman de groei van het autobezit en de aanleg van snelwegen afwijst als oorzaken van suburbanisatie. Het docl is allang geformuleerd, blik en beton zijn middelen om het te realiseren. In Reyner Banhams Los Angeles: The Architecture of Four Ecologies (1971) en Scott Bottles' Los Angeles and the Automobile (1987) wordt hetzelfde betoogd.

123. Een vergelijkbare analyse van de positie van de vrouw is te vinden in Betty Friedans The Feminine Mystique(1963).

124. Hine maakt eenzelfde punt: 'Nothing like it had ever happened before, and nothing like it has happened since'(Hine (1999): p.15).

125. Een vergelijkbare argumentatie is te vinden in Brian O'Connells 'The Federal Role in the Suburban Boom' (1989).

126. Ook in Robert Sterns Pride of Place (1986) verdwijnt de visionaire middenklasse van het toneel. In deze architectuurgeschiedenis worden geen structuren en patronen opgevoerd, maar komt het gebrek aan visie zelf 
expliciet aan de orde. Het verhaal over Amerikaanse architectuur, stelt Stern, is grotendeels een verhaal over individuen, 'strong-willed, impassioned clients and (...) individual architects with particular visions' (Stern 1986): p. 1). Eén van hun creaties is de buitenwijk, 'a remarkable achievement. (...) a complex physical embodiment of American aspirations' (ibid: p. 125). Het verhaal over het ontstaan ervan is er een van grote namen, hun idealen en prestaties. Amerika's beste suburbs zijn het resultaat van 'the daring of one visionary seeking to raise an entirely new community on a wild site' (ibid: p. 166). De laatste decennia, betoogt Stern, is het oorspronkelijke ideaal in steeds meer regio's ver te zoeken. Er is een suburb ontstaan zonder karakter, 'an impersonal subdivision, populated by hundreds of virtually identical houses' (ibid: p. 1). Wat overblijft, is de anonieme tract. Wat verloren is gegaan, is het vermogen 'to flesh out the suburb with houses, streets, and gardens that can breathe life - the gift of individuality - into it' (ibid: p. 125). Het ontbreekt volgens Stern aan het inzicht en de moed van de visionair.

127. In een bijdrage aan de bundel Die Zukunft des Raums - The Future of Space (1994) spreekt Fishman zelfs van 'a radical new space/time conception' (Fishman (1994): p. 104).

128. Vergelijkbaar is Jon Teafords betoog in Post-Suburbia (1997). Hij benadrukt zelfs dat post-suburbia ondanks belangrijke verschillen met zijn voorganger intellectueel en emotioneel 'solidly suburban' blijft (zie Teaford (1997): hoofdstukken 1, $6 \mathrm{en}$ 7). William Sharpe en Leonard Wallock gaan in 'Bold New City or Built-Up'Burb?' (1994) nog een stap verder. Zij verwerpen de 'suburbia is dead'-these en betogen dat 'the "old" suburbia still flourishes'(Sharpe en Wallock (1994): p.13).

129. James Wunsch gebruikt de ontwikkeling van postsuburbia om een disciplinair debat op scherp te zetten. Hij beschuldigt Fishman ervan niet zoals het een historicus betaamt te midden van verandering continuilteit te laten zien (zie Wunsch (1995)). Volgens deze opvatting zou de socioloog Baldassare zich op dit punt een beter geschiedschrijver tonen dan de historicus Fishman.

130. Zie Baxandall en Ewen (2000): hoofdstukken 13 en 14. Naast deze sociaal-politicke strijd besteedt Picture Windows aandacht aan verzet tegen een kerncentrale en watervervuiling, de opzet van een onderzoek naar de vele gevallen van borstkanker en het gevecht - voornamelijk door vrouwen tegen sprawl.

131. Zie bijvoorbeeld Badcocks Unfairly Structured Cities (1984), Davis' City of Quartz (1992) en 'Fortress Los Angeles' (1994), Harvey's The Urban Experience (1989), Logan en Stearns' 'Suburban Racial Segregation as a Nonecological Process' (1981), Massey en Dentons 'Suburbanization and Segregation in U.S. Metropolitan Areas' (1988) en 'Hypersegregation in U.s. Metropolitan Areas' (1989), Sennetts The Fall of Public Man (1977) en The Uses of Disorder (1996), Sibley's Geographies of Exclusion (1995) en Stearns en Logans 'The 
Racial Structuring of the Housing Market and Segregation in Suburban Areas' (1986). Zie in Nederland bijvoorbeeld Boomkens' De angstmachine (1996) en Reijndorps 'The architecture of more ecologies' (1995).

132. Overigens tekent Wright aan dat bewaking van de status-quo niet altijd 'negatieve redenen' heeft, zoals in kleine gemeenschappen die zichzelf proberen te beschermen tegen de effecten van grondspeculatic (zie Wright (1993): hoofdstuk 14). Baxandall en Ewen besteden kort aandacht aan wat zij 'more forward-looking suburban housing alternatives' noemen, waaronder new towns geïnspireerd door de new town movement uit de jaren twintig en dertig en cohousing-projecten waarin democratie en diversiteitzowel qua klasse, ras, leeftijd als type huishouden - expliciete doelstellingen zijn (zie Baxandall en Ewen(2000): conclusie).

133. De andere vier zijn Rabbit Redux (1971), Rabbit is Rich (1981), Rabbit at Rest (1990) en 'Rabbit Remembered'(2000).

134. Aangenomen wordt dat voor Brewer-opgevoerd als de vijfde stad van Pennsylvania-Reading model heeft gestaan en Shillington voor Mt. Judge. 135. Lee toont zich tevens een erfgename van Whyte, in de zin dat ze benadrukt dat het suburbane probleem in de materièle omgeving is ingebakken. 'The passivity, the non-exertion, had been built into the suburb,' (Lee (1963): p. 129) schrijft ze bijvoorbeeld in een kritick op het ontbreken van trottoirs.

136. Voor haar man John zijn vooral de hypotheeklasten een probleem: 'A man with a house is nailed to its floor'(Keats (1957): p. xiv).

137. Aprils eerste reactic op het nieuwe huis werpt haar schaduw vooruit. Ze ziet dat het afwijkt van de nabijgelegen pastelkleurige nieuwbouw, maar schrikt van het grote raam - 'a big black mirror' - dat ook hun suburbane woning domineert - 'it does have the picture window,' zegt ze tegen Frank, 'I guess there's no escaping that'(Yates (2001): p. 29).

138. Deze indruk wordt versterkt door de wisseling in het perspectief in Yates' roman. Met zijn vrouw en kinderen - zij gaan naar familie-verliest Frank uiteindelijk ook de focalisatic, eerst aan April, vervolgens aan Shep en Milly Campbell en uiteindelijk aan Helen Givings en de verteller.

139. Er bestaan andere invullingen van het concept dan die in dit hoofdstuk. Bakhtin zelf zet nergens systematisch uiteen wat hij precies onder de 'chronotoop' verstaat en diverse commentatoren hebben het verschillend gedefinieerd. Zie bijvoorbeeld Stacy Burtons 'Bakhtin, Temporality, and Modern Narrative' (1996), Stuart Allans 'When Discourse is Torn from Reality' (1994) (onder meer over 'chronotopiciteit') en John Bender en David Wellbery's inleiding van de bundel Chronotypes(1991)(over het 'chronotype').

140. Dat discoursen - of talen, wereldbeelden, ideologieèn, gezichtspunten 
en zelfs individuele uitspraken - naast elkaar bestaan, noemt Bakhtin 'heteroglossia', hun onderlinge strijd 'dialogisme' (zie Bakhtins 'Discourse in the Novel' (1998c)). Robert Stam typeert Bakhtins pleidooi voor diversiteit als 'an intrinsic identification with difference and alterity, a built-in affinity for the oppressed and the marginal' (Stam (1990): p. 141).

141. Bakhtins opvattingen over de roman maken deel uit van een complexe en veelomvattende literatuurtheoric. Belicht worden onder meer de relatie tussen auteur, verteller en personage, de bijdrage van de lezer aan de betekenis van het werk, de verhouding van de roman tot andere (literaire en niet-literaire) genres, het vermogen van de roman zaken steeds weer in twijfel te trekken, te ontleden en uit te dagen en het gebrek aan 'completedness' dat zowel personages als hun omgeving kenmerkt - belangrijk is dat de wereld die in de roman wordt verbeeld, altijd volop in ontwikkeling is (zie Bakhtins 'The Bildungsroman and Its Significance in the History of Realism' (1986), 'Problems of Dostoevsky's Poetics' (1994), 'Epic and Novel' (1998a) en 'Discourse in the Novel'(1998C)).

42. De kracht zit hem in de details en de complexiteit van de particuliere situatic. In Mikhail Bakhtin: Creation of a Prosaics (1992) spreken Gary Morson en Caryl Emerson van 'rijkdom'. In 'Strange Synchronies and Surplus Possibilities' (1993) spreekt Morson van een "thick" description of human thinking and action'(Morson (1993): p. 477).

143. In The Dialogic Imagination (1998) beschouwt Michael Holquist de chronotoop als een eenheid van analyse: 'a unit of analysis for studying texts according to the ratio and nature of the temporal and spatial categories represented'(Holquist(1998): p. 425).

144. Bakhtin geeft een aantal klassieke voorbeelden: de weg (waarop in veel romans belangrijke ontmoetingen plaatshebben), het kasteel (in de gotische roman), de salon (waar personages in bijvoorbeeld Balzacs en Stendhals werk ideeën en gevoelens uitwisselen), het kleinburgerlijke provinciestadje in bijvoorbeeld Flauberts Madame Bovary (waarin helemaal niets lijkt te gebeuren) en de drempel in bijvoorbeeld Dostojevski's werk (geassocieerd met een crisis in het leven van een personage). Zie voor chronotopen in Wilsons The Man in the Grey Flannel Suit (1955) 'De buitenwijk als tussenstop' (Hamers (2001a): pp. 333-9). Naast deze chronotopische motieven in individuele teksten onderscheidt Bakhtin chronotopen die een genre als geheel kenmerken. Ze zijn medebepalend voor de aard van ruimte en tijd daarin, het karakter van personages, het soort gebeurtenissen dat erin kan plaatshebben en de verwachtingen van lezers.

145. Zie Updike (1991a): pp. 15-22. In een eerdere uitgave van Rabbit, Run worden de lijnen en namen op de kaart expliciet aangeduid als een net waarin Rabbit opnieuw gevangen zit. In de editie waarnaar ik verwijs, volstaat Updike - in de lange reeks van verwijzingen naar netten, valstrikken, hokken, gevangschap en ontsnappingspogingen - met de suggestic van de net-metafoor. 
146. Roddelen per telefoon is een terugkerend motief in de verbeelding van de buitenwijk. Niet alleen in Rabbits Mt. Judge, maar bijvoorbeeld ook in Arthur Douglas' Oakstown en Piet Hanema's Tarbox verspreidt nieuws zich razendsnel through the grapevine, wat bijdraagt aan de beklemming die de drie ervaren.

147. Harry's verlangen naar richting in zijn leven krijgt zijn duidelijkste uitdrukking in de symboliek van de baan die zijn golfbal aflegt: 'a line straight as a ruler-edge' (ibid: p. 78). In 'het echte leven' blijft deze rechte lijn buiten Harry's bereik. Zelfs op de golfbaan - die hij vanaf Rabbit is Rich tot aan zijn dood in Rabbit at Rest bezoekt - zal hij niet meer zo'n mooic bal slaan.

148. In Harry's beleving zijn zij 'ghosts of the urgent ejaculations he has spat into the mild bodies of women'(Updike(1991a): p. 114). Met zijn tweede kind nemen zijn verantwoordelijkheden ten opzichte van Janice alleen maar toe. Later blijkt bovendien Ruth zwanger te zijn, waardoor ook zijn verplichtingen ten opzichte van haar toenemen.

149. Bovendien huilt Becky onafgebroken, wat bij herlezing van de roman een donkere schaduw vooruitwerpt. Zij lijkt Harry en Janice te willen waarschuwen voor ontwikkelingen die later een fatale afloop zullen krijgen.

150. Hij vraagt Janice' vader zelfs waarom men hem niet gewoon opsluit. 'It disgusts him to feel the net of law slither from him. They just won't do it for you, they just won't take you off the hook' (ibid: p. 165).

151. In dit opzicht ligt de kiem van Rabbit, Run in het eerder verschenen korte verhaal 'Ace in the Hole' (1959). Net als Harry 'Rabbit' Angstrom was Fred 'Ace' Anderson in zijn jeugd een basketbalster. En net als Rabbit zoekt ook Ace zijn toevlucht in herinneringen om zijn problemen in het heden te ontvluchten.

152. Algemener is Joost Zwagermans typering van Updike's werk in Pornotheek Arcadic (2000). Waar sommige critici het minachtend hebben over ouderwets huiskamerrealisme, spreekt Zwagerman van een beurtelings wurgende en troostende alledaagse huiselijkheid, verknoopt met 'een feilloos gecartografeerd tijdsbeeld van de vlottende Amerikaanse samenleving'(Zwagerman (2000): p. 138).

153. Zie respectievelijk Richard Gilmans 'An Image of Precarious Life' (1979), Richard Locke's 'Rabbit's Progress' (1979), Gerry Brenners 'Rabbit, Run: John Updike's Criticism of the "Return to Nature" (1982) en Clinton Burhans' 'Things Falling Apart' (1982).

154. Over het karakter van Updike's realisme lopen de meningen uiteen. Updike zelf spreekt van een 'stijl van tedere exploratie die zich om de dingen wikkelt, om tinten, stemmen en geuren, om de bevattelijke werkelijkheid' (Updike geparafraseerd in Zwagerman (2000): p. 138). Anderen kritiseren de overmaat aan detail, met name in beschrijvingen van de fysieke omgeving (bijvoorbeeld interieurs en gebruiksvoorwerpen). De al te minutieuze portretten van het alledaagse zouden rieken naar effectbejag en zouden zelfs kunnen worden opgevat als een parodie op realistische conven- 
ties, waarmee de realistische illusie wordt ondermijnd (zie onder andere Donald Greiners john Updike's Novels(1984): p. 149 en David Lodge's 'Post-Pill Paradise Lost' (1979): p. 91). Volgens David Thorburn is het misleidend Updike een 'straightforward realist' te noemen. Vermeers schilderkunst komt meer in de richting van zijn ideaal, stelt hij in "Alive in a Place and Time' (1979): 'those miracles of accurate rendering that yet sacralize or transfigure what is ordinary' (Thorburn (1979): p. 4). De beschrijvingen van de baan van de golfbal in Rabbit, Run en, zoals we nog zullen zien, de kerkbrand in Couples (1968) kunnen deze opvatting illustreren. In het alledaagse, aardse kondigt het hogere zich aan.

155. Er staat bijvoorbeeld net éen fauteuil meer dan nodig is. Bovendien vormen deze gemakkelijke stoelen een prachtig contrast met wat dominee Eccles omschrijft als het vermogen van Janice' moeder 'to create uneasiness', een gave 'thoroughly meshed into the strategies of middle-class life' (Updike(19912): p. 86).

156. De tegenwoordige tijd waarin Rabbits verhaal wordt verteld, draagt daaraan nog bij. Voortdurend staat Rabbit als het ware op het punt opnieuw in cen impuls te handelen. Hij verkeert permanent in een soort paniek, doordat hij niet de tijd heeft eens rustig na te denken.

157. Wat allerminst wil zeggen dat Eccles de waarheid in pacht heeft. Ook zijn blikveld is beperkt. Bovendien mag hij het hart misschien op de goede plaats hebben, bij vlagen toont hij zich minstens zo'n grote twijfelaar en lafaard als Harry zelf. Eccles' vrouw Lucy laat ik hier kortheidshalve als focalisator buiten beschouwing.

158. Als de neerwaartse spiraal aan het eind van de roman uitmondt in Harry's binnenwereld wordt op de lezer een ambigu appèl gedaan. We worden verleid met Harry mee te voelen en de ontsnapping als een opluchting te ervaren, onder andere doordat het gevoel van bevrijding ook in het ritme van de slotzin tot uitdrukking komt: '(...) with an effortless gathering out of a kind of sweet panic growing lighter and quicker and quieter, he runs. Ah: runs. Runs' (ibid: p. 177). Tegelijkertijd roept de aaneenschakeling van eerdere mislukte vluchtpogingen de nodige reserve op. Bij lezing van Rabbit, Runs opvolger Rabbit Redux blijkt deze scepsis niet onterecht. Tien jaar na zijn vlucht is Rabbit nog steeds bij Janice en is hun huwelijk nog even slecht. 159. Vijf jaar voor het verschijnen van de roman Couples die hier centraal staat, schrijft Updike een verhaal met dezelfde titel. Het wordt afgewezen door The New Yorker, maar verschijnt later in beperkte oplage.

160. Tarbox is gemodelleerd naar Ipswich, Massachusetts.

161. Tot drie keer toe wordt dit kennis-motief tijdens hun eerste ontmoeting herhaald in de vorm van 'he knew' (zie Updike (1982): p. 23). Later, als Foxy de abortus ondergaat, stelt Piet bovendien: 'She had intruded a drastic dimension. He had been innocent amid trees. She had demanded that he know. Straight string of his life, knotted. The knot surely was sin'(ibid: p. 376).

162. De top van de parabool krijgt fysieke uitdrukking in de ouderdomsver- 
schijnselen die Piet en zijn vrienden vertonen. Freddy is kaal, Janets borsten zijn gaan hangen, Angela is haar taille kwijt, Piet wordt grijs en krijgt rimpels. Overigens is Piet niet de enige die is geobsedeerd door de dood. Met name Freddy is geîntrigeerd door alles wat met verval, rotting, ziekte en dood te maken heeft. Voor hem staat vast dat het in het leven slechts bergafwaarts gaat. Als tandarts ruikt hij de dood dagelijks tussen 4 e tanden van zijn patiënten, vertelt hij Angela. 'We die. We don't die for orle second out there in the future, we die all the time, in every direction' (ibid: p. 370). Ook op de achtergrond speelt de dood een grote rol in Couples. be media berichten onder meer over de dood van de paus en de baby van de Kennedy's, de moord op John F. Kennedy zelf en Lee Harvey Oswald, een gezonken onderzeeboot, neergestorte vliegtuigen en een aardbeving.

163. In Couples komen seks en dood op talloze wijzen in combinatie voor: in het motto ontleend aan Alexander Bloks 'The Scythians', in de toespelingen op overeenkomsten tussen Piet en John F. Kennedy, tijdens het feestje dat wordt gegeven ondanks Kennedy's dood, rond de abortus van Foxy's baby, de dood van vriend John Ong en de seksuele verlangens van zijn vrouw en Freddy Thorne's opmerkingen als 'Death excites me. Death is being screwed by God' (ibid: p. 370). De relatic tussen God, seks en de dood staat in veel interpfetaties van Couples centraal: zie onder andere Donald Greiners John Updike's Novels en Victor Strandberg 'John Updike and the Changing of the Gods' (1982). In veel interpretaties wordt bovendien gewezen op de mythologische subtekst van Piets huwelijksleven, escapades en doodsangst. Piet is Tristan, die zich in zijn liefde voor Isolde (Angela) tracht te verliezen om daarmee aan de dood - of in elk geval aan de angst daarvoor - te ontsnappen. Tegelijkertijd is Piet Don Juan, die aan de greep van de dood wil ontsnappen door vele vrouwen te beminnen (zie naast Updike's 'More Love in the Western World' (1965) onder andere Alice en Kenneth Hamiltons The Elements of John Updike (1970), G. F. Wallers 'Updike's Couples' (1972), Joyce Markle's Fighters and Lovers (1973), Linda Plagmans 'Eros and Agape' (1976), Robert Detweilers ‘Updike's Couples' (1982) en Sukhbir Singhs 'Fire, Rain, Rooster'(1996).

164. Het lot van de hamster kan worden beschouwd als een voorbode van de dood van Piet en Foxy's ongeboren kindje. Piet beschouwt de ontsnapping als cen 'dim-witted little exploration that had ended with such a thunderclap of death' (Updike (1982): pp. 76-7). Als hij het beestje begraaft, associeert hij bovendien de lente - eerder de aankondiging van nieuw leven. door Foxy belichaamd - met de dood. Piet voelt hoe 'spring's terror washed over him. He felt the slow thronging of growth as a tangled hurrying toward death'(ibid: p. 78 ).

165. Zo is de haan de enige die Piet de keer dat Foxy zwanger raakt, ziet wegsluipen. Zijn vrienden kan hij ontlopen, God betrapt hem op heterdaad. De haan kan worden geassocieerd met Mt. Judge, de 'oordeelsberg' die in Rabbit, Run boven Harry's woonplaats uittorent. 
166. Dat slippertjes zich volgens (ongeschreven) regels voltrekken, noemt H. Petter in 'John Updike's Metaphoric Novels' (1982) treffend een vorm van 'geritualiseerd non-conformisme' (Petter (1982): p. 108).

167. Hoewel ze elkaar vaak bedriegen, gaan Updike's personages zelden over tot echtscheiding, merkt Joyce Flint op in 'John Updike and Couples' (1968). Updike's wASP-personages verlangen zodanig naar continutreit dat ze ondanks allerlei spanningen niet aansturen op een breuk (zie Flint (1968): p. 345).

168. Linda Plagman wijst bovendien op de bijbelse structuren die in Couples 'Edenic' Tarbox opleveren (zie Plagman (1976): pp. 83-4). David Lodge beschouwt Tarbox niet alleen als pastoraal en paradijselijk suburbia, maar platst de gemeenschap van paren bovendien in een literaire traditie van (mislukte) utopische experimenten (zie Lodge (1979): pp. 84-5, 88-9).

169. Ook op het tussenliggende niveau - dat van het echtpaar - is het hoogtepunt voorbij. Piet denkt over zijn en andermans huwelijk na in termen van opeenvolgende fasen. Na een van de eerste ontmoetingen vraagt hij Angela bijvoorbeeld in welk stadium Foxy en Kens huwelijk verkeert. Het herinnert aan de zes stadia die een personage in Updike's korte verhaal 'Four Sides of One Story' (1966) onderscheidt: 'passion, consummation, satiety, contentment, boredom, betrayal' (Updike (1967a): p. 74). In Couples doorlopen de meeste echtparen de laatste drie of vier stadia: verzadiging, sleur, verraad.

170. In dit verband interpreteert Piet de predestinatieleer op een manier die hem uitkomt. Wat hij ook doet of laat, meent hij, Gods oordeel staat vast, dus waarom zijn zondige relatie met Foxy beëindigen? Bovendien bidt hij op het moment dat Foxy alle steun kan gebruiken dat God zich over hem ontfermt. Nadat hij Zijn geboden keer op keer aan zijn laars heeft gelapt, vraagt hij God hem te verlossen van de consequenties van zijn gedrag. Tot slot laat hij zijn vrouw het vuile werk opknappen. In ruil voor Freddy's hulp bij de abortus, zegt Piet hem een nachtje met Angela toe.

171. Bovendien doet Lasch' psychological man geen beroep meer op een priester voor bijstand, maar wendt hij zich tot de psychiater. Ook in Tarbox is het geloof als centrum van geestelijke oriëntatie uit het leven verdwenen. Voor velen neemt seks deze plaats in, voor sommigen, waaronder Angela, de psycholoog. Couples staat daarmee in een traditie waarin het suburbane bestaan wordt opgevat als een psychologisch probleem. Het bekendste voorbeeld hiervan is The Split-Level Trap (1960), maar ook in literaire verhalen bezoeken buitenwijkbewoners veelvuldig de psycholoog of psychiater, zoals bijvoorbeeld Francis Weed in Cheevers 'The Country Husband' (1967) en Joanna Eberhart in Levins The Stepford Wives(1972). In French' The Women's Room (1977) wordt Lily zelfs opgenomen in een gesloten inrichting, evenals John Givings in Yates' Revolutionary Road (1961). In Moody's The Ice Storm (1994), tot slot, gebruikt Elena Hood psychologische handboeken om zichzelf te analyseren. 172. Sennetts kritiek krijgt veel navolging: zie bijvoorbeeld Kunstlers The 
Geography of Nowhere (1993), Duany en Plater-Zyberks Towns and Town Making Principles (1991) en Boomkens' De angstmachine (1996) en Een drempelwereld (1998).

173. Piet en Foxy's verstoting houdt hiermee verband. Solidariteit, betoogt Sennett, gaat voortdurend gepaard met wantrouwen. De gemeenschap houdt de gelederen slechts gesloten zolang haar leden zich aan de regels houden. Ook al is in Tarbox bekend dat vrijwel iedereen overspelig is, de stellen houden elkaar scherp in de gaten. Wie de regels overtreedt, pleegt verraad. Zo is echtscheiding een vorm van verandering die de kring niet accepteert. Dus als Angela Piet verlaat, laat de groep Piet vallen. De groepsdynamiek na een ordeverstoring door een van de leden noemt Sennett een 'fratricidal rhythm'(Sennett(1993): p. 311).

174. Een andere, recentere kritiek op Updike's werk waarop ik hier niet zal ingaan, is dat zijn middle America een verdediging inhoudt van een nadrukkelijk blank, mannelijk, heteroseksueel en vermogend Amerika (zie bijvoorbeeld Sally Robinsons ““Unyoung, Unpoor, Unblack"'(1998)).

175. Coupland zelf heeft geèrgerd gereageerd op deze hype. In een interview met Bart Vanegeren bekent hij dat zijn irritatie zelfs heeft geresulteerd in cen argwaan tegen het schrijverschap (zie Vanegeren (2000a): p. 28 en (200ob): p. 156). Jarenlang wil Coupland niets zeggen over zijn debuutroman, omdat hij zijn Generation $X$ in de verste verte niet herkent in het $\mathrm{x}$-etiket dat in de media op van alles en nog wat wordt geplakt. Uit de stapels artikelen uit talloze tijdschriften over onder andere marketing, onderwijs- en bestuurskunde, theologie, psychologie, sociologie, politicologie, economie, communicatie- en cultuurwetenschap wil ik éen voorbeeld geven. In The Futurist omschrijft consultant Bob Losyk de generatie $\mathrm{X}$ als volgt: "“Generation X" $(. .$.$) realize the numbers are on their side. They (. .$. see themselves as very marketable in the workplace. They feel that they can be patient when choosing a job, and they can look for the best wages' (Losyk (1997): pp. 39-40). Een groter contrast met Couplands personages is nauwelijks denkbaar.

176. De wijze waarop Bell wordt neergezet, krijgt in de jaren tachtig en negentig navolging in de portretten van mooie, jonge, rijke yuppies in onder andere Bret Easton Ellis' en Jay McInerney's werk.

177. Bells fascinatic en afschuw wat betreft consumptic, prestatic en status is een vorm van cultuurkritiek die in latere romans van DeLillo terugkeert. In White Noise (1984) houdt Jack Gladney zich bijvoorbeeld bezig met overmatige consumptie en toenemende milieuverontreiniging, in Underworld (1997) staat naast de nucleaire dreiging de almaar groeiende afvalberg centraal. 
178. In het verhaal 'Viewfinder' (1989a) treffen we eveneens cenrman aan die alleen is achtergebleven in zijn suburbane woning. Door zich rondom het huis te laten fotograferen, lijkt hij zijn situatie te willen bezweren, alsof hij de relatie met deze plek nieuw leven wil inblazen door de band tussen hem en zijn huis vast te leggen. De fotograaf begrijpt het, maar waarschuwt dat hij zijn gezin met deze foto's niet terugkrijgt.

179. Vergelijkbare vervreemding en communicatiestoornissen kenmerken het gezin in het verhaal 'In the Islands', uit Ellis' bundel The Informers (1994). 180. In de loop van de cyclus verlaat de middenklasse de binnenstad, neemt het antal achterstandswijken gestaag toe en wordt een suburb als Mt. Judge - in Rabbit, Run (1960) nog een onaantrekkelijke buurt - een modicu$z e$, dure buitenwijk voor yuppen. Een tweede ontwikkeling in de gebouwde omgeving die in verband met Generation $X$ interessant is, is de spraw/ van nieuwbouwwijken en de horizonvervuiling door fastfoodketens en grootwinkelbedrijven waaraan Harry zich, met name eind jaren tachtig in Rabbit atRest (1990), ergert.

181. Couplands Shampoo Planet (1992) kan worden gelezen als een roman over deze generatic. Hoofdpersonage Tyler Johnson is carrièregericht en materialistisch. In zijn leven staan design, consumptic en cosmetica centraal.

182. Omdat ze nog niet is benoemd, wordt ze met een ' $X$ ' aangeduid. Andy vergelijkt de Amerikaanse generatic X met een Japanse generatic twintigers, de 'shin jin rui (...) new human beings' (Coupland (1995a): p. 56). Een belangrijk verschil tussen de twee landen is volgens hem dat Amerika meer ruimte biedt om in te verdwijnen: 'to hide in - to get lost in - to use as camouflage. You're not allowed to disappear in Japan' (ibid). In Updike's Rabbit at Rest wordt een vergelijkbare parallel getrokken tussen jongeren in Amerika en Japan. 'Young people now most interesting,' vertelt Mr. Shimada, die namens Toyota het dealerschap van de Angstroms komt intrekken. 'Not scared of starving as through most human history. Not scared of atom bomb as until recently. But scared of something - not happy. In Japan too. Brue Jeans, rock music not make happiness enough' (Updike (1991d): p. 391). 183. In zijn bijdrage aan de bundel Near Encounters (1995) legt Bernd Herzogenrath eveneens een verband tussen de generatie Xen de lost generation. Hij omschrijft beide als gedesillusioneerde generaties die er door een gebrek aan bakens niet of nauwelijks in slagen zich te oriènteren: 'an old faith lost and no new one got' (Herzogenrath (1995): p. 131). Een andere aanduiding van de generatie $\mathrm{X}$ die eveneens doelt op een generatic schrijvers is blank generation. Daartoe worden aanvankelijk de zogenoemde brat-pack-auteurs Tama Janowitz, Bret Easton Ellis en Jay Mcinerney gerekend en later ook auteurs als Lynne Tillman, Pagan Kennedy en Dennis Cooper (zie voor een uitgebreide uiteenzetting van hun werk bijvoorbeeld Robert Siegle's Suburban Ambush (1989) en Elizabeth Young en Graham Caveney's bundel Shopping in Space (1992)). Later wordt ook Douglas Couplands werk aangemerkt 
als zogenaamde blank fiction, product van de generatie X (zie tivoorbeeld James Annesley's 'Decadence and Disquiet' (1996)).

184. Moore sluit expliciet aan bij de opvattingen over postmodrniteit van Fredric Jameson, David Harvey en Lawrence Grossberg. Literauurwetenschapster Lies Wesseling bespreekt de generatie $\mathrm{X}$ in een artika in De Gids in termen van Richard Rorty's ironie en Jean Baudrillards hyprreele consumptic-en mediacultuur (zie Wesseling (2000): pp. 418-20).

185. Hoewel de diagnosen overeenkomen, krijgen in verschillede studies verschillende generaties gestalte en overlappen generaties elkar, doordat ze verschillend worden afgebakend. Soms wordt een onderschel gemaakt tussen de generatie $X$ en de protestgeneratic, soms tussen ouder en jongere babyboomers, soms tussen een sixties-en eighties-generatie.

186. In Declining Fortunes (1993) richt Newman zich met name' $p$ de verwachtingen, teleurstellingen en onzekerheid van de generatidie in de jaren tachtig de arbeidsmarkt betreedt. In het bijzonder gaat haa aandacht uit naar de middenklasse in een suburb in New Jersey, opgevoer onder de naam Pleasanton.

187. De hand keert bovendien nog terug in de uitdrukking 'the land that history dealt them' (Newman (1993): p. 198), waarin eveneens de ndruk ligt upué onmacint van ae jonge middenklasse.

188. Andy's tirade kan worden beschouwd als een hedendaagse variant van de traditionele aanklacht tegen behoudzucht in het suburbia van de middenklasse. Met één aanklacht vertoont ze bijzondere overeenkomsten. In het verhaal 'The Wrysons' (1958) introduceert John Cheever een suburbaan echtpaar dat net als Andy's ouders als de dood is voor verandering. Hun ongerustheid manifesteert zich als een angst voor 'a stranger at the gates unwashed, tirelessly scheming, foreign, the father of disorderly children who would ruin their rose garden and depreciate their real estate investment, a man with a beard, a garlic breath (...) '(Cheever (1976): p. 120). Overigens worden zij net als Andy's ouders niet alleen met afkeer neergezet, maar ook met de nodige sympathie.

189. Een paginagrote tekening naast Andy's verhaal over de familiefoto associeert het flitslicht van de fotograaf met de flits van een ontploffende atoombom, wat een extra schaduw over de toekomst werpt. Ook in 'The Wrong Sun' uit Couplands bundel Life After God (1994) staat boven een be schouwing over de invloed van nucleaire dreiging in het middenklassemilieu een tekening van een flitsend fototoestel (zie Coupland (1995b): p. 109). 190. Een hieraan verwante term in de marge is homeowner cnvy: 'feelings of jealousy generated in the young and the disenfranchised when facing gruesome housing statistics' (Coupland (1995a): p. 144).

191. Sennetts kritiek is geenszins helemaal van toepassing op de situatie in Palm Springs. Andy en zijn vrienden hebben bijvoorbeeld wel degelijk contact met buitenstaanders en ontvangen hen zelfs in hun midden. Bovendien valt moeilijk vol te houden dat hun afzondering destructieve gevolgen 
heeft, afgezien van het vandalisme waaraan Dag zich soms schuldig maakt. 192. Dat deze afspraak nodig is, blijkt bijvoorbeeld uit het feir dat Andy pas in zijn laatste verhaal - een verhaal dat hij niet eens aan Dag en Claire heeft durven vertellen - zichzelf als hoofdpersoon opvoert en zich niet, zoals tot dan toe, verschuilt achter een fictionele stand-in.

193. In de marge wordt een van deze verhalen vergezeld door de neologismen survivulousness - 'the tendency to visualize oneself enjoying being the last remaining person on Earth. "I'd take a helicopter up and throw microwave ovens down on the Taco Bel'" (ibid: p. 62) - en mental ground zero - 'the location where one visualizes oneself during the dropping of the atomic bomb; frequently, a shopping mall' (ibid: p. 63). Nucleaire dreiging en het einde van de wereld keren ook elders in Couplands werk terug, bijvoorbeeld in 'Postcard from Los Alamos (Acid Canyon)' uit de bundel Polaroids from the Dead (1996) en de roman Girlfriend in a Coma (1998). In 'The Wrong Sun' uit Life After God wordt een direct verband gelegd tussen deze fascinatic voor het nucleaire einde en het middenklassebestaan. "In modern middle-class culture, the absence of death in most people's carly years creates a psychic vacuum of sorts. For many, thoughts of a nuclear confrontation are one's first true brush with nonexistence, and because they are the first, they can be the most powerful and indelible' (Coupland (1995b): p. 109).

194. Dag kiest voor de tweede persoon, waarmee hij zijn toehoorders in zijn verhaal betrekt, Andy en Claire als het ware vraagt zich voor te stellen wat zij zouden doen in deze supermarkt, op dit moment.

195. In beide raken in het suburbia van de jaren zeventig gezinnen ontwricht en steken verveling, seksuele spanningen en geweld elkaar in ogenschijnlijk zo gewone middenklasselevens naar de kroon - in Eugenides' roman tegen een achtergrond van toenemende milieuproblematiek, in die van Moody in een sfeer van neerwaartse mobiliteit.

196. Steeds gaat het, impliciet dan wel expliciet, om een vergelijking tussen verwachtingen van de blanke middenklasse, toen en nu. Vergelijking van blank met zwart zou wellicht een heel andere conclusie opleveren.

197. Nog grimmiger is het perspectief in Donna Gaines' Teenage Wasteland (1991), een sociologisch-ctnografische studie van probleemjongeren in het suburbia van eind jaren tachtig. Sommige van Gaines' formuleringen doen denken aan die van Ehrenreich en Newman. 'The world out there seems less wellcoming than it once was,' betoogt ze bijvoorbeeld. 'It has less to offer, and the road is harder. There are fewer free spaces, no buffer zone of affluence, no surplus cushions to fall back upon. (...) In recent years many American kids have had their dreams taken from them. Their vision has been blocked, unable to move beyond next week, because the world outside is simply too much' (Gaines (1991): pp. 54, 253). Elders schakelt ze over op het slang van de tieners die ze heeft gevolgd en kiest ze voor de tweede persoon om hun perspectief tot leven te wekken. 'The possibilities of suburbia are exhausted, and your capacity to dream has reached a dead end. But 
nobody cares, nobody gives a shit' (ibid: p. 54).

198. Deze wijkende toekomst komt niet overeen met het perspectief van de no future generation uit Guy Kirsch' 'Time Preference and Social Decision Making' (1988). In tegenstelling tot Andy, Dag en Claire voelt deze generatie zich zelfs in het privé-domein machteloos. We kunnen Andy en zijn vrienden eerder rekenen tot Kirsch' shifting involvements-groep (zie Kirsch (1988): pp. 202-3).

199. Ook deze verhalen zijn op te vatten als de tales uit de ondertitel van Generation X, in dit geval herinnerend aan Geoffrey Chaucers The Canterbury Tales (ca. 1478), een raamvertelling waarin het beste verhaal van pelgrims wordt beloond met een gratis maaltijd in de Tabard Inn.

200. In de marge krijgt zowel het ideaal als de teleurstelling uitdrukking. We kunnen Andy's trek naar Mexico opvatten als een vorm van emallgration: 'migration toward lower-tech, lower-information environments containing a lessened emphasis on consumerism' (Coupland (1995a): p. 173). Eenmaal aangekomen, zou hij wel eens last kunnen krijgen van expatriate solipsism: uit ergernis niet spreken met mensen die dezelfde vreemde, verafgelegen plek hebben opgezocht en zo je exotische dromen verpesten (zie ibid: p. 172).

201. Ook in Don DeLillo's White Noise boezemt een grote wolk het hoofdpersonage een bijna religieus ontzag in. Jack Gladney is met zijn gezin per auto op de vlucht voor een gifwolk die mythische, kosmische proporties aanneemt en net als in Generation X omstanders dichter bij elkaar brengt. Waar Andy een band krijgt met verstandelijk gehandicapten, voelt Gladney bijzondere sympathie voor een groep psychiatrische patiënten (zie DeLillo (1999): pp. 127-8).

202. Het is niet alleen zeer de vraag of Dag en Claire's hotel er komt, ook Andy's eigen voornemens blijven erg vaag. Over éen ervan vertelt hij. Het is een verhaaltje over een jongeman die huwelijk en carrière eraan geeft om in een oude roestbak de prairies over te rijden op zoek naar stormen. Hij wil door de bliksem worden getroffen. Dag en Claire vonden dit verhaal een mislukking, omdat aan het eind niet duidelijk wordt of de jongeman in zijn opzet slaagt. Hij zwerft nog steeds rond, wat Andy geruststelt, maar nauwelijks een concreet toekomstplan inhoudt.

203. Zie voor een uitgebreidere uiteenzetting van Couplands Brentwood als belichaming van postmoderniteit 'Een dag uit het leven van een buitenwijk' en 'Having arrived, time to move on' (Hamers (1999) en (2001b)).

204. Zie bijvoorbeeld Dowalls 'An Examination of Population GrowthManaging Communities' (1980), Logans 'Growth, Politics, and the Stratification of Places' (1978), Logan en Molotch' Urban Fortunes (1987) en Maurer 
en Christensons 'Growth and Nongrowth Orientations of Urban, Suburban and Rural Mayors' (1982).

205. Er zijn legio voorbeelden van L.A. als angstbeeld. Al in Richard Mathesons korte verhaal 'The Creeping Terror' uit 1961, bijvoorbeeld, bedreigt L.A. als een cindeloze schimmel van asfalt en citrusbomen Amerika. In The Lovittowners (1967) is dat volgens Herbert Gans de grote angst van critici: sprawl zal Amerika veranderen in één groot L.A. (zic Gans (1982): p. xxviii). In Curt Gentry's Last Days of the Late, Great State of California (1968) vult de stad niet alleen de open ruimte volledig op, maar is ze bovendien het decor van ernstige rassenrellen. Recenter is bijvoorbeeld Ridley Scotts film Blade Runner (1982), waarin het L.A. van 2019 één groot dystopisch wasteland is.

206. Kenneth Jackson haalt in zijn bijdrage aan de bundel Suburbia (1976) zelfs cen suburbane rabbi aan die bekent dat in zijn jeugd in Brooklyn het chique Five Towns op Long Island nog meer dan Israel het beloofde land representeerde (zie Jackson (1976): p. 92).

207. Zie onder andere Huxley (1975): Pp. 30, 38, 50, 51 en 172. Illustraties uit de utopische traditie wil ik beperken tot Brave New World (1932). Niet alleen als utopie, maar vooral ook als dystopie vertoont het parallellen met 'Brentwood Notebook'. Een saillant detail in dit verband is dat Huxley voordat hij Brave New World schreef een maand doorbracht aan de Amerikaanse westkust. Naar verluidt leverde het leven daar ingrediěnten voor zijn dystopische roman.

208. Net als ideaal suburbia heeft de utopie een dergelijke omgeving nodig als negatief referentiepunt. 'De utopie,' schrijft Achterhuis, 'bestaat bij gratie van de apocalyps, het geluk straalt des te schitterender als men het vergelijkt met rampspoed en ellende' (Achterhuis (1998): p.90).

209. Zie naast Boomkens (1996): hoofdstuk 3 en (1998): hoofdstuk 5, Jackson (1976): pp. 103, 104, 106, Rowe (1991): p. 39 en Baljon (1995) bijvoorbeeld ook David Sibley's Geographies of Exclusion (1995).

210. Nimby is de afkorting van de uitdrukking not in my backyard.

211. In de suburbiakritiek is Irvine, Orange County emblematisch voor de ver doorgevoerde beheersing van en controle op de woonomgeving en het gedrag van bewoners. Edward Soja omschrijft in 'Inside Exopolis' (1992) Irvine's community groups en homeowners associations zelfs als legers die vechten voor veiligstelling van territorium, identiteit en de 'premises and promises' die ze hebben aangeschaft(Soja (1994): p. 117).

212. Zie naast de in noot 131 van hoofdstuk 3 genoemde studies bijvoorbeeld Duncan en Duncans 'Deep Suburban Irony' (1997) en 'The Aestheticization of the Politics of Landscape Preservation' (2001), Schwartz' 'The Evolution of the Suburbs' (1976) en Wyckoffs 'Landscapes of Private Power and Wealth'(1990).

213. Een heel andere, veel politieker gerichtheid op het heden vinden we in Helga Nowotny's Time (1994), waarin de categorie 'toekomst' wordt afgeschaft en wordt vervangen door de notie van een extended present (zie Nowot- 
ny (1994): hoofdstuk 2). Een groot verschil met het 'uitgerek heden' in Brentwood is dat Nowotny oproept in the extended present in: spelen op problemen, terwijl Brentwoodians problemen ontkennen of e deur wijzen.

214. Over de status van exemplarische buitenwijken wordt z den uitgeweid. Uitzonderingen zijn Fishmans Bourgeois Utopias (1987), parin wordt benadrukt dat deze suburbs niet typisch, maar exemplarisch jn voor het suburbia in een bepaalde periode (zie Fishman (1987); p. 13), 1 Margaret Marsh' Suburban Lives (1990), waarin wordt gesteld dat exemprische buitenwijken niet representatief zijn (zie Marsh (1990): p. xv).

215. Het werkelijkheidsgehalte van de wijk wordt ook in kor re typeringen gethematiseerd. In een passage over de dood van Marilyn Nnroe associeert Coupland het moment waarop zij twijfelt of ze de pillezal slikken met 'Brentwood dreaming, dreaming whether or not to live odie' (Coupland (1997): p. 176). Een ander voorbeeld dat ook met roem te $\mathrm{r}^{\mathrm{k} k e n}$ heeft, ontleent Coupland aan Ned Wynns memoires We will Always $I^{c}$ in Beverly Hills. Daarin wordt een Bret Easton Ellis-achtige discussie gevird over de vraag of sterren wel echte mensen zijn. Dat iemand in Brentvod woont, garandeert niet dat iemand ook echt bestaat:

"He looked at me and made a face. "Is your dad Van Johnson or not?" he demanded.

"He's my stepfather," I said. "Keenan Wynn's my father." I waited for the awe, the homage.

"Never heard of that guy. My sister's big on movie stars, but I don't care about them one iota. They're all phonies, anyway, not real people."

If felt my skin prickle.

"They are so real," I said.

"Sure they are," he said. I swallowed and my eyes started to sting.

"My dad is real," I choked. "He lives in Brentwood"'(ibid:p. 161).

216. Wie het notebook leest als slotstuk van Polaroids from the Dead is mogelijk al gevoelig voor genrekwesties voordat hij begint aan het stuk over Brentwood. Niet alleen komen in de bundel heel verschillende thema's aan de orde, ook de vormen waarin deze uitdrukking krijgen, verschillen enorm. De bundel bevat onder meer een serie fictionele verhalen over bezoekers aan een concert van Grateful Dead, een impressie van een ontmoeting met een journalist, ansichtkaarten, herinneringen aan Vancouver, een brief aan het overleden grunge-idool Kurt Cobain en een reeks zogenoemde microstories, fictionele verhaaltjes van hooguit drie pagina's over uiteenlopende onderwerpen.

217. Zie naast de reeds genoemde titels bijvoorbeeld James Duncans 'Landscape Taste as a Symbol of Group Identity' (1973) en 'Elite Landscapes as Cultural (re)Productions' (1992) en James en Nancy Duncans 'A Cultural Analysis of Urban Residential Landscapes in North America' (1984).

218. In Rick Moody's Purple America (1997) zoekt het hoofdpersonage zijn 
heil in alcohol. Een oplossing biedt de drank Dexter Raitliffe niet. Aan het eind van zijn terugkeer naar de buitenwijk van zijn moeder blijft wie dood wil in leven en raakt een ander gewond. Uiteindelijk rent Dexter met het jachtgeweer nog in zijn hand over suburbane gazonnetjes en golfcourses, langs vijvers en zwembaden. In Dave Eggers' A Heartbreaking Work of Staggering Genius (2000) komt deze suburbane suspense fraai tot uitdrukking in een korte typering van het Lake Forest uit de jeugd van de verteller: 'it was very quiet sometimes, oddly quiet, and underneath the quiet there was the tiniest, faintest sound, like air being let out of a narrow hole, a sound like someone screaming from worlds away, and people were dying in dark and bewildering ways'(Eggers (2001): p. 193).

219. De wijze waarop het notebook speelt met 'feiten' rond Brentwood heeft overeenkomsten met de aan New Journalism verwante reportage- of non-fictieroman of faction, maar omdat het geen verhaal vertelt, past het ook in deze categorie niet. In De theorie van vertellen en verhalen (1978) definieert Mieke Bal een verhaal als "een op een bepaalde wijze gepresenteerde geschiedenis. Een geschiedenis is een serie logisch en chronologisch aan elkaar verbonden gebeurtenissen, die worden veroorzaakt of ondergaan door"acteurs"' (Bal (1990): p. 18).

220. Belangrijke focalisatoren zijn twee arme jongens die in de wijk klusjes opknappen, een jongeman die op het punt staat een heilloos huwelijk te sluiten, een rijke jonge vrouw die zichzelf van het leven berooft, een vrouw die door haar man in een kelder is opgesloten en een grootgrondbezitter die als geen ander weet wat er mis is in deze gemeenschap.

221. Scanscape (1999) bevat naast McNeils 'Mirrors, Bathtubs, and Remote Controls' een tweede essay. Ook in 'Commodifying the Garden of Eden' voert Peter Marcuse een spanning op tussen een ogenschijnlijk volmaakt oppervlak en het gemis dat daaronder schuilgaat. Moeders kijken op straat naar hun kleine kinderen op driewielers, vaders doen op het veilige speelplein een balspel met hun zonen, tieners liggen bij het zwembad. Men lacht, is ontspannen en geniet van rust en harmonic. Maar er ontbreekt iets. 'Life is flat,' betoogt Marcuse, 'like the cardboard cutouts advertising its advantages. Whole dimensions of life are missing: challenge and achievement, diversity and wonder, history and expectation, the messiness of nature and the order of the spheres. There is nothing to threaten but also nothing to astonish'(Marcuse in Rader (1999): p. 83).

222. Zie voor Herbert Gans' en William Dobriners pleidooien voor de sociologie en James Wunsch' pleidooi voor geschiedschrijving als wetenschappelijke disciplines noot 11 in hoofdstuk 1.

223. Een literair werk, betoogt Paul Ricoeur bijvoorbeeld in het tweede deel 
van Time and Narrative (1983-5), "cuts out a fleeting perspective of aindscape beyond,' 'a world capable of being inhabited' (Ricoeur (1985): pioo). Het kan de lezer meenemen in deze wereld, wat volgens de Frannan niet alleen betekent de ruimte erin te verkennen en te ervaren, maarvengoed de tijd. Juist in de verbeelding van tijd huist volgens Ricoeur eenelangrijke kwaliteit van literatuur.

224. Zie bijvoorbeeld deel 1 uit David Lodge's The Modes of Modn Writing (1989) en de inleiding en hoofdstuk x van J.J.A Mooijs Fiction Realities (1993).

225. Planologische fictionaliteit, voegt Holstein toe, is van tijddjke aard. Meestal is het de bedoeling de gepresenteerde beelden later te vewezenlijken; de fictionaliteit is ontworpen om uiteindelijk te worden op 226. Deze omschrijving is afkomstig uit Updike's dankwoord ij de ontvangst van de National Book Award voor zijn roman The Ceniur (1963), geciteerd in Thorburn(1979): p. 4. 


\section{Bibliografie}

Achterhuis, H. (1998). De erfenis van de utopie. Amsterdam: Ambo.

Adam, B. (1990). Time and Social Theory. Cambridge: Polity Press.

Allan, S. (1994). 'When Discourse is Torn from Reality'. Bakhtin and the principle of chronotopicity. Time and Society, 3(2), 193-218.

Ankersmit, F.R.(1996a). De spiegel van het verleden. Exploraties : geschiedtheorie. Kampen: KokAgora.

Ankersmit, F. R. (1996b). De macht van representatic. Exploraties n: cultuurfilosofie en esthetica. Kampen: Kok Agora.

Annesley, J. (1996). Decadence and Disquiet. Recent American Fiction and the Coming Fin de Siedcle. Journal of American Studies, 30(3), 365-79.

Badcock, B.(1984). Unfairly Structured Ciries. Oxford: Basil Blackwell.

Bakhtin, M.M. (1986). The Bildungsroman and Its Significance in the History of Realism (Toward a Historical Typology of the Novel). In C. Emerson \& M. Holquist (red.), Speech Genres and Other Late Essays (pp. 10-59). Austin, Texas: University of Texas Press.

Bakhtin, M.M. (1994). Problems of Dostoevsky's Poetics. In P. Morris (red.), The Bakhtin Reader. Selected Writings of Bakhtin, Medvedev and Voloshinov (pp. 98-102). Londen: Edward Arnold.

Bakhtin, M.M. (1998a). Epic and Novel. In M. Holquist (red.), The Dialogic Imagination. Four Essays by M. M. Bakhtin (pp. 3-40). Austin, Texas: University of Texas Press.

Bakhtin, M.M. (1998b). Forms of Time and of the Chronotope in the Novel. Notes toward a Historical Poetics. In M. Holquist (red.), The Dialogic Imagination. Four Essays by M.M. Bakhtin (pp. 84-258). Austin, Texas: University of Texas Press.

Bakhtin, M. M. (1998c). Discourse in the Novel. In M. Holquist (red.), The Dialogic Imagination. Four Essays by M.M. Bakhtin (pp. 259-422). Austin, Texas: University of Texas Press.

Bal, M. (1990). De theorie van vertellen en verhalen. Muiderberg: Coutinho.

Baldassare, M. (1986). Trouble in Paradise. The Suburban Transformation in America. New York: Columbia University Press.

Baldassare, M. (1992). Suburban Communities. Annual Review of Sociology, 18 , 475-94.

Baljon, L. (1995). LandschapsArchitectuur in Los Angeles. In D. Bakker, R. 
Brouwers, G. Dales \& L. Hermans (red.), Expeditie L.A. Roterdam: NAi Uitgevers.

Banham, R. (1971). Los Angeles. The Architecture of Four Ecologies. Inden: Allen Lane.

Baudrillard, J.(1995). America (Vert. uit het Frans door C. Turne). New York: Verso.

Baxandall, R. \& Ewen, E. (200o). Picture Windows. How the Subtbs Happened. New York: Basic Books.

Bender, J. \& Wellbery, D.E. (1991). Introduction. In J. Bender \&D. Wellbery (red.), Chronotypes. The Construction of Time (pp.1-15). Stanfor, Californie: Stanford University Press.

Benton, S. (1991). Gender, Sexuality and Citizenship. In G. Artrews (red.), Citizens and Responsibilities (pp. 151-63). Londen: Lawrence \&Vishart.

Berger, B.M. (1968). Working-Class Suburb. A Study of Auto Worke in Suburbia. Berkeley en Los Angeles, Californië: University of Caliform Press.

Berger, B. M. (1971a). The Myth of Suburbia. In B. M. Berger (ed.), Looking For America. Essays on Youth, Suburbia, and Other American Obsecions (pp. 15164). Englewood Cliffs, New Jersey: Prentice-Hall.

Berger. B. M (1973bL. Suburbs. Subcultures, and Stryles of Liffein B.M. Berger (red.), Looking For America. Essays on Youth, Suburbia, and Other American Obsessions (pp. 165-87). Englewood Cliffs, New Jersey: Prentice-Hall.

Bertens, H. \& D'haen, T. (1983). De geschiedenis van de Amerikaanse literatuur. Amsterdam: De Arbeiderspers.

Binford, H.C. (1988). The Early Nineteenth-Century Suburb. Creating a Suburban Ethos in Somerville and Cambridge, Massachusetts, 18201860. In D. Schaffer (red.), Two Centuries of American Planning (pp. 41-6o). Baltimore, Maryland: The Johns Hopkins University Press.

Boomkens, R. (1996). De angstmachine. Over geweld in films, literatuur en popmuziek. Amsterdam: De Balie.

Boomkens, R. (1998). Een drempelwereld. Moderne ervaring en stedelijke openbaarheid. Rotterdam: NAi Uitgevers.

Boomkens, R. (1999). Babbelen in het paradijs. Van buitenhuis tot woonerf, of de 'Werdegang' van de suburbanisatie. De Gids(8), 577-84.

Booth, W. (1983). The Rhetoric of Fiction. Chicago: The University of Chicago Press.

Bottles, S.L. (1987). Los Angeles and the Automobile. The Making of the Modern City. Berkeley en Los Angeles, Californiè: University of California Press.

Boyle, T.C.(1996). The Tortilla Curtain. Londen: Penguin Books.

Brenner, G. (1982). Rabbit, Run: John Updike's Criticism of the 'Return to Nature'. In W.R. Macnaughton (red.), Critical Essays on John Updike (pp. 91-104). Boston, Massachusetts: G.K.Hall and Co.

Bunce, M. (1994). The Countryside Ideal. Anglo-American Images of Landscape. Londen: Routledge.

Burchard, J. \& Bush-Brown, A. (1961). The Architecture of America. A Social and 
Cultural History. Boston, Massachusetts: Little, Brown and $\mathrm{Ca}$.

Burhans jr., C.S. (1982). Things Falling Apart. Structure and Theme in Rab. bit, Run. In W. R. Macnaughton (red.), Critical Essays on John Updike (Pp. 148-62). Boston, Massachusetts: G. K. Hall and Co.

Burton, S. (1996). Bakhtin, Temporality, and Modern Narrative. Writing 'the Whole Triumphant Murderous Unstoppable Chute'. Comparative Literature, $48(1), 39-64$.

Calthorpe, P. (1993). The Next American Metropolis. Ecology. Community, and the American Dream. New York: Princeton Architectural Press.

Campbell, C. (1989). The Romantic Ethic and the Spirit of Modern Consumerism. Oxford: Basil Blackwell.

Carver, R. (1989a). Viewfinder. In What We Talk About When We Talk About Love (pp. 11-5). New York: Vintage Books.

Carver, R. (1989b). Why Don't You Dance? In What We Talk About When We Talk About Love (pp. 3-10). New York: Vintage Books.

Cauter de, L. (1995). Ancheologie van de kick. Verhalen over moderniteit en ervaring. Amsterdam: De Balie.

Chandler, M.R. (1989). Voices Crying in the Suburbs. In B.M. Kelly (red.), Suburbia Re-examined (pp. 215-22). Westport, Connecticut: Greenwood Press.

Cheever, J.(1969). Bullet Park. New York: Ballantine Books.

Cheever, J. (1976). The Wrysons. In Some People, Places, and Things That Will Not Appear in My Next Novel (pp. 119-3o). Plainview, New York: Books for Libraries Press.

Cheever, J. (1992). The Country Husband. In D. Angus \& S. Angus(red.), Contemporary American Short Stories (pp. 245-74). New York: Fawcett Crest.

Clarke, A. J. (1997). Tupperware. Suburbia, Sociality and Mass Consumption. In R. Silverstone (red.), Visions of Suburbia (pp. 132-6o). Londen: Routledge.

Coontz, S. (1992). The Way We Never Were. American Families and the Nostalgia Trap. New York: Basic Books.

Coupland, D.(1993).Shampoo Planet. Londen: Simon \& Schuster.

Coupland, D. (1995a). Generation X. Tales for an Accelerated Culture. Londen: Abacus.

Coupland, D. (1995b). Life After God. Londen: Simon \& Schuster.

Coupland, D. (1997). Polaroids from the Dead. Londen: Flamingo.

Coupland, D.(1998). Girlfriend in a Coma. New York: HarperCollins.

Crawford, M. (1994). The World in a Shopping Mall. In M. Sorkin (red.), Variations on a Theme Park. The New American City and the End of Public Space (pp. 3-3o). New York: Hill and Wang.

Crawford, M.(1995). Building the Workingman's Paradise. The Design of American Company Towns. Londen en New York: Verso.

Cross, G. (1997). The Suburban Weekend. Perspectives on a Vanishing Twen- 
tieth-Century Dream. In R. Silverstone(red.), Visions of Surbia (pp. 108 31). Londen: Routledge.

Davis, M. (1992). City of Quartz. Excavating the Future in Los Anges. New York: Vintage.

Davis, M. (1994). Fortress Los Angeles. The Militarization offrban Space. In M. Sorkin (red.), Variations on a Theme Park. The New Anrican City and the End of Public Space (pp.154-80). New York: Hill and Wany

Davis, M. (1998). Ecology of Fear. Los Angeles and the Imagination o Disaster. New York: Metropolitan Books.

DeLillo, D.(1990). Americana. Londen: Penguin Books.

DeLillo, D. (1998). Underworld. New York: Simon \& Schuster.

DeLillo, D. (1999). White Noise. Londen: Picador.

Detweiler, R. (1982). Updike's Couples: Eros Demythologized n W. R. Macnaughton (red.), Critical Essays on John Updike (pp. 128-39) 30ston, Massachusetts: G.K. Hall and Co.

Dobriner, W. M. (1958). Introduction. Theory and Research inhe Sociology of the Suburbs. In W. M. Dobriner (red.), The Suburban Cnmunity (pp. xni-kxvnij:ivew xôn:

Dobriner, W.M. (1963). Class in Suburbia. Englewood Cliffs, New Jersey: Prentice-Hall.

Donaldson, S. (1968). City and Country. Marriage Proposals. American Quarterly (3), 547-66.

Donaldson, S. (1969). The Suburban Myth. New York en Londen: Columbia University Press.

Doner, D. (1979). Rabbit Angstrom's Unseen World. In D. Thorburn \& H. Eiland (red.), John Updike. A Collection of Critical Essays (pp. 17-34). Englewood Cliffs, New Jersey: Prentice-Hall.

Donkers, J. (2001).Ja hoor, ze houden wel van me. Op 7 september 2001 ontleend aan: http://www.nrc.nl/cultuur/boeken/999839975032.html.

Douglass, H.P. (1970). The Suburban Trend. New York: Johnson Reprint Corporation.

Dowall, D.E. (1980). An Examination of Population Growth-Managing Communities. Policy Studies Journal(9), 414-27.

Duany, A., Plater-Zyberk, E. \& Krieger, A. (1991). Towns and Town-Making Principles. New York: Rizzoli.

Duany, A., Plater-Zyberk, E. \& Speck, J. (2001). Suburban Nation. The Rise of Sprawl and the Decline of the American Dream. New York: North Point Press.

Duncan, J.S. (1973). Landscape Taste as a Symbol of Group Identity. A Westchester County Village. The Geographical Review (63), 334-55.

Duncan, J.S. (1992). Elite Landscapes as Cultural (re)Productions. The Case of Shaughnessy Heights. In K. Anderson \& F. Gale(red.), Inventing Places. Studies in Cultural Geography (pp. 37-51). Melbourne: Longman Cheshire Pty. 
Duncan, J.S. \& Duncan, N.G. (1984). A Cultural Analysis of Urban Residential Landscapes in North America. The Case of the Anglophile Elite. In J.A.Agnew, J. Mercer \& D. E. Sopher (red.), The City in Cultural Context (pp. 255-76). Boston, Massachusetts: Allen and Unwin.

Duncan, J.S. \& Duncan, N.G. (2001). The Acstheticization of the Politics of Landscape Preservation. Annals of the Association of American Geographers, $91(2), 387-409$.

Duncan, N.G. \& Duncan, J.S. (1997). Deep Suburban Irony. The Perils of Democracy in Westchester County, New York. In R. Silverstone (red.), Visions of Suburbia (pp.161-79). Londen: Routledge.

Eggers, D. (2001). A Heartbreaking Work of Staggering Genius. New York: Vintage Books.

Eggleston, W. (2002). William Eggleston's Guide. New York: Museum of Modern Art.

Ehrenreich, B. (1989). Fear of Falling. The Inner Life of the Middle Class. New York: Pantheon Books.

Eiland, H. (1979). Play in Couples. In D. Thorburn \& H. Eiland (red.), John Updike. A Collection of Critical Essays (pp. 69-83). Englewood Cliffs, New Jersey: Prentice-Hall.

Ellis, B.E.(1987). Less than Zero. Londen: Penguin Books.

Ellis, B.E.(1995). The Informers. Londen: Picador.

Eugenides, J. (200o). The Virgin Suicides. New York: Warner Books.

Eyerman, R. \& Löfgren, O. (1995). Romancing the Road. Road Movies and Images of Mobility. Theory, Culture \&Society, $12(1)$, 53-79.

Farley, R. (1964). Suburban Persistence. American Sociological Review, 29 (1), 3847.

Fava, S. (1956). Suburbanism as a Way of Life. American Sociological Review (februari), 34-7.

Federman, R. (1988). Self-Reflexive Fiction. In E. Elliott (red.), Columbia Literary History of the United States (pp.1142-57). New York: Columbia University Press.

Fishman, R. (1987). Bourgeois Utopias. The Rise and Fall of Suburbia. New York: Basic Books.

Fishman, R. (1988). The Post-War American Suburb. A New Form, A New City. In D. Schaffer (red.), Two Centuries of American Planning (pp. 265-78). Baltimore, Maryland: The Johns Hopkins University Press.

Fishman, R. (1994). Die neue Stadt des 20. Jahrhunderts. Raum, Zeit und Sprawl / The New City of the 2oth Century. Space, Time and Sprawl. In B. Meurer (red.), Die Zukunft des Raums = The Future of Space (pp. 91-105). Frankfurt/Main: Campus Verlag.

Fishman, R. (1996). Re-Imagining Los Angeles. In M. J. Dear, H. E. Schockman \& G. Hise (red.), Rethinking Los Angeles (pp. 251-61). Thousand Oaks: 


\section{Sage Publications.}

Flint, J. (1968). John Updike and Couples. The w A SP's DilemmaResearch Studies, 36(4),340-7.

French, M. (1980). The Women's Room. Londen: Sphere Books.

Gaines, D. (1991). Teenage Wasteland.Suburbia's Dead End Kids. Ne York: Pantheon Books.

Gans, H.J.(1968). People and Plans. Essays on Urban Problems and Siutions. New York: Basic Books.

Gans, H.J. (1982). The Levittowners. Ways of Life and Politics in a itw Suburban Community. New York: Columbia University Press.

Garreau, J. (1992). Edge City. Life on the New Frontier. New York: Arhor Books.

Gilman, R. (1979). An Image of Precarious Life. In D. Thorburr\& H. Eiland (red.), John Updike. A Collection of Critical Essays (pp. 13-6). Englwood Cliffs, New Jersey: Prentice-Hall.

Gordon, R.E., Gordon, K. K. \& Gunther, M. (1961). The Split-Letl Trap. New York: Bernard Geis Associates.

Greenhouse, L. (1974). Growth Crying Out for Guidance. In L.L. Masotti \&

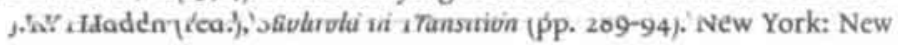
Viewpoints.

Greiner, D. J. (1984). John Updike's Novels. Athens, Ohio: Ohio University Press. Gruenberg, S. (1954, 19 september). Homogenized Children of New Suburbia. The New York Times Magazine.

Hamers, D. (1999). Een dag uit het leven van een buitenwijk. Couplands Brentwood als object van empirische filosofie. KEM: Tijdschrift voor empirische filosofic (4), 327-60.

Hamers, D. (2001a). De buitenwijk als tussenstop. Over suburbane tijd en identiteit in The man in the grey flannel suit. Psychologic en Maatschappiy. 97 (4), $331-44$.

Hamers, D. (2001b). Having Arrived, Time to Move on. Coupland's Brentwood as an experiment with space and time. Environment and Planning A. $33(12), 2109-25$.

Hamilton, A. \& Hamilton, K. (1970). The Elements of John Updike. Grand Rappids: Eerdmans.

Haraway, D.J. (1989). Primate Visions. Gender, Race and Nature in the World of Modern Science. Londen: Routledge.

Harris, R. \& Lewis, R. (1998). Constructing a Fault(y) Zone. Misrepresentations of American Cities and Suburbs, 1900-1950. Annals of the Association of American Geographers, 88(4), 622-39.

Harris, R. \& Lewis, R. (2001). The Geography of North American Cities and Suburbs, 1900-1950. A New Synthesis. Joumal of Urban History, 27 (3), 26292.

Harvey, D. (1989). The Urban Experience. Oxford: Basil Blackwell. 
Herbers, J. (1974). A Deep Uneasiness About the Future. In L.H. Masotti \& J.K. Hadden (red.), Suburbia in Transition (pp. 283-8). New York: New Viewpoints.

Herzogenrath, B. (1995). From the Last Generution to Generation X. The Great Gatsby versus Kurt Cobain. In H. Berressem \& B. Herzogenrath (red.), Near Encounters. Festschrift for Richand Martin (pp. 121-40). Frankfurt/Main: Peter Lang.

Hine, T.(1999). Populuxe. New York: Alfred A. Knopf.

Hoffman, A. (200o). Local Girls. New York: Berkeley Books.

Holquist, M. (1998). Glossary. In M. Holquist(red.), The Dialogic Imagination.

Four Essays by M.M. Bakhtin (pp. 423-34). Austin, Texas: University of Texas Press.

Holstein, A.N. (1998). IJburg als mythe. K\&M: Tijdschrift voor empirische filosofic (4), 368-92.

Howard, E. (1965). Garden Cities of To-morrow. Londen: Faber and Faber.

Hummon, D.M. (1990). Commonplaces. Community Ideology and Identity in American Culture. Albany: State University of New York Press.

Huxley, A. (1975). Brave New World. Harmondsworth: Penguin Books.

Huxtable, A. L. (1974). An Alternative to 'Slurbs'. In L. H. Masotti \& J. K. Hadden(red.), Suburbia in Transition (pp. 185-91). New York: New Viewpoints.

Jackson, K.T. (1976). The Effect of Suburbanization on the Cities. In P.C. Dolce (red.), Suburbia. The American Dream and Dilemma (pp. 89-11o). Garden City, New York: Anchor Press.

Jackson, K.T. (1987). Crabgrass Frontier. The Suburbanization of the United States. New York: Oxford University Press.

Jacobs, J. (1961). The Death and Life of Great American Cities. New York: Vintage Books.

Jensen, S. (2002). Waarom vrouwen van apen houden. Een liefdesgeschiedenis in cultuur en wetenschap. Amsterdam: Bert Bakker.

Jurca, C. (1999). The Sanctimonious Suburbanite. Sloan Wilson's The Man in the Gray Flannel Suit. American Literary History, 11(1), 82-106.

Karp, D. (1965). Leave MeAlone. Harmondsworth: Penguin Books.

Katz, P. (1994). The New Urbanism. Toward an Architecture of Community. New York: McGraw-Hill.

Keating, A.D. (1989). Real Estate Developers: Creators of Improved Subdivisions, Mentors of Suburban Government. In B.M. Kelly (red.), Suburbia Re-cxamined (pp. 199-206). Westport, Connecticut: Greenwood Press.

Keats, J. (1957). The Crack in the Picture Window. Cambridge, Massachusetts: The Riverside Press.

Kelly, B.M. (1989). Preface. In B.M. Kelly (red.), Suburbia Re-examined (pp. xvxvi). Westport, Connecticut: Greenwood Press.

Kelly, B.M. (1993). Expanding the American Dream. Building and Rebuilding Levit- 
town. Albany: State University of New York Press.

Kirsch, G. (1988). Time Preference and Social Decision Making.n G. Kirsch, P. Nijkamp \& K. Zimmermann(red.), The Formulation of TimPreferences in a Multidisciplinary Perspective (pp. 189-204). Berlijn: Avebury.

Kling, R., Olin, S. \& Poster, M. (1991). The Emergence of Postaburbia. An Introduction. In R. Kling, S. Olin \& M. Poster (red.), Postsubrban California. The Transformation of Orange County since World War $I$ (Pp.-3o). Berkeley en Los Angeles, Californiě: University of California Pres.

Kneeland, D. (1974). There Is No Firm Stereotype. In L. H. Msotti \& J. K. Hadden (red.), Suburbia in Transition (pp. 272-7). New York New Viewpoints.

Korr, J. (1997). A Proposed Model for Cultural Landscape StudyMaterial Culture, $29(3), 1-18$.

Kumar, K. (1987). Utopia and Anti-Utopia in Modern Times. OxfordBasil Blackwell.

Kunstler,J.H.(1994). The Geography of Nowhere. The Rise and Declie of America's Man-Made Landscape. New York: Touchstone.

Làscn', C.71979).' İ̉é Cutrure of Nadrcısstsm. American Lifé in An Age of Diminishing Expectations. New York: Warner Books.

Lee, D. (1963). Suburbia Reconsidered: Diversity and the Creative Life. In E. Geen, J. R. Lowe \& K. Walker (red.), Man and the Modern City (pp. 122-34). Pittsburgh, Pennsylvania: University of Pittsburgh Press.

Leeuwen van, A. (1993, 4 december). Welkom in Suburbia: stad van gezin, carrière en welverdiend genieten. Elsevier, 28-33.

Leonard jr., G.B. (1958, 18 februari). The American Male: Why Is He Afraid to Be Different? Look.

Levin, L. (1972). The Stepford Wives. New York: Random House.

Levine, G. (1987). One Culture: Science and Literature. In G. Levine (red.), One Culture. Essays in Science and Literature (pp.3-32). Madison: University of Wisconsin Press.

Lindner, R. (1956). Must You Conform? New York: Rinehart and Co.

Locke, R. (1979). Rabbit's Progress. In D. Thorburn \& H. Eiland (red.), John Updike. A Collection of Critical Essays (pp. 35-8). Englewood Cliffs, New Jersey: Prentice-Hall.

Lodge, D. (1979). Post-Pill Paradise Lost: Couples. In D. Thorburn \& H. Eiland (red.), John Updike. A Collection of Critical Essays (pp. 84-92). Englewood Cliffs, New Jersey: Prentice-Hall.

Lodge, D. (1989). The Modes of Modern Writing. Metaphor, Metonymy, and the Typology of Modern Literature. Londen: Edward Arnold.

Logan, J. R. (1978). Growth, Politics, and the Stratification of Places. American Journal of Sociology (84), 404-16.

Logan, J.R. \& Molotch, H. (1987). Urban Fortunes. Berkeley, Californiě: Unjversity of California Press. 
Logan, J.R. \& Stearns, L. B. (1981). Suburban Racial Segregation as a Nonecological Process, Social Fonces(60), 61-73.

Long, E. (1985). The American Dream and the Popular Novel. Boston, Massachusetts: Routledge en Kegan Paul.

Losyk, B. (1997). Generation X: What They Think and What They Plan to Do. The Futurist(maart-april), 39-44.

Lunt, P. K. \& Livingstone, S. M. (1992). Mass Consumption And Personal Identity. Buckingham: Open University Press.

Markle, J. B. (1973). Fighters and Lovers. Theme in the Novels of John Updike. New York: New York University Press.

Marsh, M. (1990). Suburban Lives. New Brunswick, New Jersey: Rutgers University Press.

Marx, L. (1981). The Machine in the Garden. Technology and the Pastoral Ideal in America. Londen: Oxford University Press.

Masotti, L.H., \& Hadden, J.K. (1974). Introduction. In L.H. Masotti \& J.K. Hadden (red.), Suburbia in Transition (pp. 3-12). New York: New Viewpoints.

Massey, D.S. \& Denton, N.A. (1988). Suburbanization and Segregation in U.S. Metropolitan Areas. American Journal of Sociology(94),592-626.

Massey, D.S. \& Denton, N.A.(1989). Hypersegregation in U.S. Metropolitan Areas. Black and Hispanic Segregation along Five Dimensions. Demography (26), 373-91.

Maurer, R.C. \& Christenson, J.A. (1982). Growth and Nongrowth Orientations of Urban, Suburban and Rural Mayors. Reflections on the City as a Growth Machine. Social Science Quarterly(63), 350-8.

McKinley, G. (1992). The Crime. In D. Angus \& S. Angus (red.), Contemporary American Short Stories (pp. 137-53). New York: Fawcett Crest.

Mead, M. (1972). Freedom to Choose. In C.M. Haar (red.), The End of Innocence. A Suburban Reader (pp. 18-22). Glenview, Illinois: Scott, Foresman and Co.

Meinig, D.W. (1979a). The Bcholding Eye. Ten Versions of the Same Scene. In D.W. Meinig (red.), The Interpretation of Ordinary Landscapes. Geographical Essays (pp.33-48). New York: Oxford University Press.

Meinig, D.W. (1979b). Symbolic Landscapes. Some Idealizations of American Communities. In D.W. Meinig (red.), The Interpretation of Ordinary Landscapes. Geographical Essays (pp. 164-92). New York: Oxford University Press.

Miller, D. (1984). Modernism and Suburbia as Material Ideology. In D. Miller \& C. Tilley (red.), Ideology, Power and Prehistory (pp. 37-49). Cambridge: Cambridge University Press.

Miller, D. (1991). Material Culture and Mass Consumption. Oxford: Basil Blackwell.

Mills, C.W. (1977). White Collar. The American Middle Classes. Londen: Oxford 
University Press.

Moody, R. (1998). PurpleAmerica. Boston, Massachusetts: Back Bay Books.

Moody, R. (200o). The IceStorm. Londen: Abacus.

Mooij, J.J.A. (1981). Idee en verbeelding. Filosofische aspecten van de literatuurbeschouwing. Assen: Van Gorcum.

Mooij, J.J.A. (1993). Fictional Realities. The Uses of Literary Imagination. Amsterdam en Philadelphia: John Benjamins.

Mooij,J.J.A. (2001). Tijd en geest. Een geschiedenis. Kampen: Agora.

Moore, R. (1998). '... And Tomorrow Is Just Another Crazy Scam'. Postmodernity, Youth, and the Downward Mobility of the Middle Class. In J. Austin \& M.N. Willard (red.), Generations of Youth. Youth Cultures and History in Twentieth-Century America (pp. 253-71). New York en Londen: New York University Press.

Morris, P. (1994). The Bakhtin Reader. Selected Writings of Bakhtin, Medvedev and Voloshinov. Londen: Edward Arnold.

Morson, G.S. (1991). Bakhtin, Genres and Temporality. New Literary History (22), 1071-92.

Morson, G.S. (1993). Strange Synchronies and Surplus Possibilities. Bakhtin on Time.Slavic Review, 52(3), 477-93.

Morson, G. S. (1994). Narrative and Freedom. The Shadows of Time. New Haven en Londen: Yale University Press.

Morson, G.S. \& Emerson, C. (1992). Mikhail Bakhtin. Creation of a Prosaics. Stanford, Californiè: Stanford University Press.

Muller, P.O. (1981). Contemporary Suburban America. Englewood Cliffs, New Jersey: Prentice-Hall.

Mulvey, L. (1991). A Phantasmagoria of the Female Body. The Work of Cindy Sherman. New Left Review (188), 137-50.

Mumford, L. (1961). The City in History. Its Origins, Its Transformations, and Its Prospects. New York: Harcourt, Brace \& World.

Munro, A. (1985). The Shining Houses. In Dance of the Happy Shades and Other Stories. Harmondsworth: Penguin Books.

Naylor, G. (1986). Linden Hills. New York: Penguin Books.

Newman, K.S. (1988). Falling from Grace. The Experience of Downward Mobility in the American Middle Class. New York: The Free Press.

Newman, K.S. (1991). Uncertain Seas. Cultural Turmoil and the Domestic Economy. In A. Wolfe(red.),America at Century's End (pp. 112-3o). Berkeley en Los Angeles, Californiě: University of California Press.

Newman, K.S. (1993). Declining Fortunes. The Withering of the American Dream. New York: Basic Books.

Nicholson, P.Y. (1989). The Elusive Soul of the Suburbs. An Inquiry into Contemporary Political Culture. In B.M. Kelly (red.), Suburbia Re-examined (pp. 207-13). Westport, Connecticut: Greenwood Press.

Nio, I. (1999). Verhalen uit de buitenwijk. De Gids(8), 609-17. 
Novak, M. (1982). Son of the Group. In W.R. Macnaughton (red.), Critical Essays on John Updike (pp. 59-61). Boston, Massachusetts: G.K. Hall and Co.

Nowotny, H. (1994). Time. The Modern and Postmodern Experience. Cambridge: Polity Press.

Nussbaum, M.C. (1987). 'Finely Aware and Richly Responsible'. Literature and the Moral Imagination. In A.J. Cascardi (red.), Literature and the Question of Philosophy (pp. 167-91). Baltimore, Maryland: The Johns Hopkins University Press.

Nussbaum, M.C. (1997). The Fragility of Goodness. Luck and Erhics in Greek Trogedy and Philosophy. Cambridge: Cambridge University Press.

Nussbaum, M.C. (1999). Love's Knowledge. Essays on Philosophy and Literature. New York: Oxford University Press.

O'Connell, B.J.(1989). The Federal Role in the Suburban Boom. In B. M. Kelly (red.), Suburbia Re-xamined (pp. 183-92). Westport, Connecticut: Greenwood Press.

Palen, J.J.(1995). TheSuburbs. New York: McGraw-Hill.

Petter, H. (1982). John Updike's Metaphoric Novels. In W.R. Macnaughton (red.), Critical Essays on John Updike (pp. 105-14). Boston, Massachusetts: G.K. Hall and Co.

Plagman, L.M. (1976). Eros and Agape. The Opposition in Updike's Couples. Renascence. Essays on Values in Literature, 28, 83-93.

Räder, M. (1999).Scanscape. Barcelona: Actar.

Reijndorp, A. (1995). The architecture of more ecologies. Schijn en werkelijkheid van L.A. In D. Bakker, R. Brouwers, G. Dales \& L. Hermans (red.), Expeditie L.A. Rotterdam: NAi Uitgevers.

Reijndorp, A., Kompier, V., Metaal, S., Nio, L. \& Truijens, B. (1998). Buitenwijk. Stedelijkheid op afstand. Rotterdam: NAi Uitgevers.

Ricoeur, P.(1984). Time and Narrative (Vert. uit het Frans door K. McLaughlin \& D. Pellauer, vol.1). Chicago: The University of Chicago Press.

Ricoeur, P. (1985). Time and Narrative (Vert. uit het Frans door K. McLaughlin \& D. Pellauer, vol. 2). Chicago: The University of Chicago Press.

Ricoeur, P. (1988). Time and Narrative (Vert. uit het Frans door K. Blamey \& D. Pellauer, vol.3). Chicago: The University of Chicago Press.

Riesman, D. (1950). The Lonely Crowd. A Study of the Changing American Character. New Haven: Yale University Press.

Riesman, D. (1957). The Suburban Dislocation. The Annals of The American Academy, 314,123-46.

Riesman, D. (1958). The Suburban Sadness. In W.M. Dobriner(red.), The Suburban Community (pp. 375-408). New York: G.P. Putnam's Sons.

Ristoff, D. I. (1988). Updike's America. The Presence of Contemporary American His- 
tory in John Updike's Rabbit Trilogy. New York: Peter Lang.

Robinson, S. (1998). 'Unyoung, Unpoor, Unblack'. John Updike and the Construction of Middle American Masculinity. Modem Fiction Studies, 44 (2), 331-63.

Rodaway, P. (1995). Exploring the Subject in Hyper-Reality. In S. Pile \& N. Thrift (red.), Mapping The Subject. Geographies of Cultural Transformation (pp. 241-66). Londen: Routledge.

Rorty, R. (1991). Essays on Heidegger and Others. Philosophical Papers (vol. 2). Cambridge, Massachusetts: Cambridge University Press.

Rorty, R. (1995). Contingency, Irony, and Solidarity. Cambridge, Massachusetts: Cambridge University Press.

Rossum van, H., Wijk van, F. \& Baljon, L. (2001). De stad in uitersten. Verkenningstocht naar Vinex-land. Rotterdam: NAi Uitgevers.

Rowe, P.G. (1991). Making a Middle Landscape. Cambridge, Massachusetts: The Mit Press.

Schwartz, J. (1976). The Evolution of the Suburbs. In P.C. Dolce(red.), Suburbia. The American Dream and Dilemma (pp. 1-36). Garden City, New York: Anchor Press.

Seeley, J.R., Sim, R.A. \& Loosley, E.W. (1956). Crestwood Heights. A Study of the Culture of Suburban Life. New York: Basic Books.

Sennett, R. (1993). The Fall of Public Man. Londen: Faber and Faber.

Sennett, R. (1996). The Uses of Disorder. Personal Identity and City Life. Londen: Faber and Faber.

Sharpe, W. \& Wallock, L. (1994). Bold New City or Built-Up 'Burb? Redefining Contemporary Suburbia. American Quarterly, 46(1), 1-30.

Sheed, W. (1968). Play in Tarbox. Op 20 november 2000 ontleend aan: http:// www.nytimes.com/books/97/04/o6/lifetimes/updike-r-couples.html.

Shields, R. (1992). Places on the Margin. Alternative Geographies of Modernity. Londen: Routledge.

Sibley, D. (1995). Geographies of Exclusion. Society and Difference in the West. Londen en New York: Routledge.

Siegel, F. (1997). The Future Once Happened Here. New York, D.C., LA., and the Fate of America's Big Cities. New York: The Free Press.

Siegle, R. (1989). Suburban Ambush. Downtown Writing and the Fiction of Insurgency. Baltimore, Maryland: The Johns Hopkins University Press.

Sies, M.C. (1987). The City Transformed. Nature, Technology, and the Suburban Ideal, 1877-1917. Journal of Urban History, 14(1), 81-111.

Sies, M.C. (2001). North American Suburbs, 1880-1950. Cultural and Social Reconsiderations. Journal of Urban History, $27(3), 313-46$.

Silverstone, R. (1997). Introduction. In R. Silverstone (red.), Visions of Suburbia (pp. 1-25). Londen: Routledge.

Singh, S. (1996). Fire, Rain, Rooster. John Updike's Christian Allegory in Couples. The International Fiction Review, 23(1-2), 36-43. 
Smith, H.N. (1978). Virgin Land. The American West as Symbol and Myth. Cambridge, Massachusetts: Harvard University Press.

Soja, E. (1994). Inside Exopolis: Scenes from Orange County. In M. Sorkin (red.), Variations on a Theme Park. The New American Ciry and the End of Public Space(pp. 94-122). New York: Hill and Wang.

Spigel, L. (1997). From Theater to Space Ship. Metaphors of Suburban Domesticity in Postwar America. In R. Silverstone (red.), Visions of Suburbia(pp. 217-39). Londen: Routledge.

Stam, R. (1990). Mikhail Bakhtin and Left Cultural Critique. In E.A. Kaplan (red.), Postmodernism and Its Discontents. Theories, Practices (pp. 116-45). Londen en New York: Verso.

Stearns, L.B. \& Logan, J.R. (1986). The Racial Structuring of the Housing Market and Segregation in Suburban Areas. Social Forces (65), 28-42.

Stern, R.A.M. (1986). Pride of Place. Building the American Dream. Boston, Massachusetts: Houghton Mifflin.

Stilgoe, J.R. (1988). Borderland. Origins of the American Suburb, 1820-1939. New Haven en Londen: Yale University Press.

Strandberg, V. (1982). John Updike and the Changing of the Gods. In W. R. Macnaughton (red.), Critical Essays on John Updike (pp. 175-94). Boston, Massachusetts: G.K. Hall and Co.

Teaford, J.C. (1993). The Twentieth-Century American City. Problem, Promise and Reality. Baltimore, Maryland: Johns Hopkins University Press.

Teaford, J.C. (1997). Post-Suburbia. Government and Politics in the Egde Cities. Baltimore, Maryland: The Johns Hopkins University Press.

Thomas, G.S.(1998). The United States of Suburbia. How the Suburbs Took Control of America and What They Plan to Do with It. Amherst, New York: Prometheus Books.

Thorburn, D. (1979). Introduction: 'Alive in a Place and Time'. In D. Thorburn \& H. Eiland (red.), John Updike. A Collection of Critical Essays (pp. 1-9). Englewood Cliffs, New Jersey: Prentice-Hall.

Thorns, D.C.(1972). Suburbia. Londen: MacGibbon \& Kce.

Updike, J. (1959). Ace in the Hole. In The Same Door (pp. 19-27). Greenwich, Connecticut: Fawcett.

Updike, J. (1965). More Love in the Western World. In Assorted Prose (pp. 283300). New York: Alfred A. Knopf.

Updike, J. (1967a). Four Sides of One Story. In The Music School (pp. 70-9). Greenwich, Connecticut: Fawcett.

Updike, J. (1967b). The Indian. In The Music School (pp. 14-9). Greenwich, Connecticut: Fawcett.

Updike, J.(1976). Picked-Up Pieces. Londen:André Deutsch.

Updike, J.(1982). Couples. Londen: André Deutsch.

Updike, J.(1991a). Rabbit, Run(InA Rabbit Omnibus). Londen: Penguin Books. 
Updike, J.(1991b). Rabbit Redux (InA Rabbit Omnibus). Londen: Pe'guin Books. Updike, J.(1991c). Rabbit is Rich (In A Rabbit Omnibus). Londen: Peiguin Books. Updike,J.(1991d). Rabbit at Rest. New York: Penguin Books.

Updike, J. (2001). Rabbit Remembered. In Licks of Love (pp. 15-356). New York: Ballantine Books.

Urry, J.(1995). Consuming Places. Londen: Routledge.

Vanegeren, B. $(2000,1-3)$. Doug en de opwindtechniek. De Groek Amsterdammer, 27-9.

Vanegeren, B. (2000, 29-2). 'Miss Wyoming'. Douglas Couplan' grijpt naar pruik, eyeliner en lipstick. Humo, 152-7.

Vries de, G. (1999). Zeppelins. Over filosofie, technologie en cultuur. Imsterdam: Van Gennep.

Waller, G.F. (1972). Updike's Couples. A Barthian Parable. Reseai ht Studies, 40 (1), 10-21.

Wattel, H.L. (1958). Levittown: A Suburban Communitv. In W.A. Dobriner (red.), The Suburban Community (pp. 287-313). New York: G.P. Putnam's Sons.

Weijers, I. (1991). Terug naar het behouden huis. Romanschrijvers en wetenschappers in de jaren vijftig. Amsterdam: Uitgeverij su A.

Wendorff, R. (1980). Zeit und Kultur. Geschichte des Zeitbewusstseins in Europa. Wiesbaden: Westdeutscher Verlag.

Wesseling, L. (200o). De bekering van Douglas Coupland. De Gids (6), 417* 24.

Wetherell, W.D. (1985). The Man Who Loved Levittown. In The Man Who Loved Levittown (pp. 3-22). Pittsburgh, Pennsylvania: University of Pittsburgh Press.

Whitehand, J.W.R. \& Carr, C.M.H. (1999). England's Interwar Suburban Landscapes. Myth and Reality. Journal of Historical Geography, 25 (4), 483501.

Whyte jr., W.H.(1953). The Transients. Fortune, 112-7, 221-6.

Whyte jr., W.H. (1963a). The Anti-City. In E. Geen, J.R. Lowe \& K. Walker (red.), Man and the Modern City (pp. 45-58). Pittsburgh, Pennsylvania: University of Pittsburgh Press.

Whyte jr., W.H. (1963b). The Organization Man. Harmondsworth: Penguin Books.

Wilde de, R. (1992). Discipline en legende. De identiteit van de sociologic in Duitsland en de Verenigde Staten, 1870-1930. Amsterdam: Van Gennep.

Wilde de, R. (2000). De voorspellers. Een kritick op de tockomstindustrie. Amsterdam: De Balic.

Williams, R. (1973). The Country and the City. Londen: Chatto \& Windus. Wilson, S. (1956). The Man in the Grey Flannel Suit. Londen: Cassell and Co. Wilson, S. (1976). What Shall We Wear to This Party? The Man in the Gray Flan- 
nel Suit Twenty Years Before \& After. New York: Arbor House.

Wolfe, T. (1999). A Man in Full. New York: Bantam Books.

Wood, R.C. (1958). Suburbia. Its People and Their Politics. Boston, Massachusetts:

Houghton Mifflin.

Wood, R.C. (1963). The American Suburb: Boy's Town in a Man's World. In

E. Geen, J. R. Lowe \& K. Walker (red.), Man and the Modern City (pp. 112-21). Pittsburgh, Pennsylvania: University of Pittsburgh Press.

Wright, G. (1993). Building the Dream. A Social History of Housing in America. Cambridge, Massachusetts: The Mir Press.

Wunsch, J.L. (1995). The Suburban Cliché.Journal of Social History, 28 (3), 64358.

Wyckoff, W.K. (1990). Landscapes of Private Power and Wealth. In M.P. Conzen (red.), The Making of the American Landscape (pp. 335-54). Boston, Massachusetts: Unwin Hyman.

Yates, R. (2001). Revolutionary Road. Londen: Methuen.

Young, E. \& Caveney, G. (red.). (1992). Shopping in Space. Essays on American 'Blank Generation' Fiction. Londen en New York: Serpent's Tail.

Zwagerman, J.(1995). Net zo verloren als alle anderen. De generatieromans van Douglas Coupland. Maatstaf. 43(6), 30-9.

Zwagerman, J.(2000). Pornotheek Areadie. Amsterdam: De Arbeiderspers. 


\section{Summary \\ Time for suburbia \\ The American suburb in science and literatre}

For decades the representation of the American suburb an its residents has been primarily marked by intellectual disdain This can be seen not only in magazines, television series and movie:but also in social science and humanities studies and in works of lirary fiction. In recent years this negative portrayal increasingly ret with criticism. This dissertation focuses on a discussion of theerms in ..whirbscbolarsand. liverayuautbersuntertandonmrearon the persistent and cliché-like negative representation of suburban life.

Today, a majority of Americans is living in a suburban setting, while a steadily growing number of them also work there. Although we generally view cities as having many faces and identities, our common understanding of American suburbia seems hardly balanced or diverse. This one-sided conceptualization is not just a theoretical issue, but has direct ramifications for suburban realities. It affects, for example, decisions on whether funds should go to improvements of the inner city or to development of the city's outskirts; it also influences the lay-out and outlook of new suburbs, the design of suburban housing and people's decisions on whether to go live there or not. It is quite relevant, therefore, that this particular mode of modern life is known and represented in a multifaceted manner. Similar concerns apply to an increasingly suburbanized country like the Netherlands. In this country, too, spatial planning takes place in a culture that has predominantly expressed a derogatory view of suburbia.

A major concern of this dissertation is to show that conventional attacks on suburban stereotypes and clichés fall short. To this day such attacks tend to start from the so-called suburban myth, from the view that there are inaccurate representations of the suburban reality that need to be replaced by more realistic representations. As a way to counter the repertoire that is based on this particular myth, 
I propose an alternative way of reasoning. Too often it is ignored that texts and studies do not merely describe suburban realities, but that they have us perceive such realities in a certain fashion: texts do something and directly affect our grasp of the outside world. In order to establish how this is the case, and what the specific effects are, this study does not focus on a comparison between reality and representation. It is not my aim to consider texts on suburbia and assess the accuracy of their representations. Instead, this dissertation capitalizes on a confrontation between texts that represent suburbs in a variety of ways. I will discuss scholarly studies and literary narratives side by side because they influence the world beyond their own discursive context; they have concrete effects outside their own tradition. In this study, then, texts from these various traditions function as each other's context.

Contrary to what the repertoire of myth suggests, negative representations of suburbia rarely involve simple images. The issue in this study is not so much the suburb as place, but suburbia - not so much the living environment per se, but the suburban lifestyle and mentality. Criticism leveled at suburbia is generally aimed at those who live there: members of the middle classes. Their representation involves a specific place and lifestyle, but it also has a temporal dimension: a particular engagement with the past, present and future. It is primarily their sense of time, including their embeddedness in time, on which suburbanites are judged. They are regarded as excessively nostalgic, as surrendering themselves to a hedonist present, or, conversely, as being blinded by ambition to get ahead. Moreover, their looking backward or forward is also tied to specific behavioral orientations, if not the competence to act altogether. Nostalgia and anticipation often imply fear and determination, dependency and autonomy, a lack of initiative and excessive eagerness to act.

Of course, this study, too, considers the suburb as a space that residents turn into a place. If we are to understand, however, what goes into dominant spatial constructions and what its alternatives look like in detail, we should consider the imagination of space as one in which time is a constitutive factor as well. The way in which relationships between the suburban middle classes' temporal ori- 
entations, lifestyle and behavioral orientations are portrayed significantly contributes to robust representations of suburbia. These relationships are particularly relevant in forms of representation that move away from such robustness.

A comparison of these complex constructions reveals some continuity, not only in stereotypical representations, as is suggested by studies that employ the repertoire of myth, but also in more subtle representations. Although scholarly reflection on suburbia in a variety of traditions - including urban history, sociology, historical and cultural geography, cultural philosophy and architectural critique - has prompted diverse, discipline-based discussions, it is possible to identify a limited number of recurring motifs and narratives throughout these various traditions.

The suburb of the 1950 , for instance, plays a key role. It is often invoked as a true site of middle America. Three compromises converge in it, organized around a close connection between the ideal American, the so-called new middle class and the post-war suburb. The ideal American combines individuality with community sense: as an independent individual he is part of a harmonious group. The new middle class, mainly consisting of office clerks with a stable family life and an individual career, is seen to express a combination of calmness and competitive spirit. Represented as a whole, this class is after social-economic mobility based on traditional, closeknit family life. Divided into lower and upper middle class, the solid citizens in the first category mainly display satisfaction with what they have, while the career makers from the latter category strive for upward mobility and display hypersensitivity for status differences. The social-political compromise between individuality and community and the economic compromise between composure and competition come together in a third, temporal compromise. The fifties-suburb is seen to express both stability and progress. Depending on how the suburb is evoked, two forms of status anxiety can be distinguished. If the focus is on an individual suburb, in most cases there is a collective effort towards ensuring social status. But if the focus is on a mosaic of suburbs, career is central in most cases, whereby moving from one suburb to another is identical to an upward move on the social ladder. 
Since the 1950 s the suburb counts as the ultimate site for the middle classes to express the American ideal of being home and of moving on - of satisfied retrospection and eager anticipation. The grand narratives of the autonomous individual, the harmonious nuclear family, the stable community, upward mobility and material prosperity become entwined with the true site of middle America and turn it into a particularly robust notion. This robustness is further enhanced by five cultural ideas that have a much wider footing in American culture and society: paradise, the pastoral, the picturesque, the frontier and the city. These constitute a reservoir of notions - on time and place as well as identity - from which elements can be drawn for imagining community and individuality, peacefulness and mobility, security and renewal, nostalgia and ambition. Depending on the suburb's specific representation a fitting selection of these elements may be invoked. Paradise and the picturesque lend themselves for instance to the image of the perfect, (all too) carefully managed comfort in a beautiful, green setting. If not being home but moving on is seen as central, the narratives tied to the frontier tradition, in which entrepreneurial individuals take their destiny into their own hands (while ignoring that of others) are most appropriate. A combination of both types is frequently expressed by reverting to the (American) pastoral, which links up pristine rural life with a belief in progress.

Although in the past fifty years individual elements from this complex system may have been criticized, the basic formula has not been undermined. It can be found as a constant in the representation of the suburb as both ideal and nightmare. The valuations vary substantially, though. Suburbia counts as promise and disappointment, as heartland and wasteland.

The suburb is a battleground where intellectuals fight each other at three levels. Depending on what they expect from the individual and how they conceive of its behavior and competence to act, they sketch mutually competing versions of suburbia. The first issue concerns the loss of individuality. It is not just the suburb as a built environment that meets with criticism; its residents are also seen in a negative light. The monotonous suburb is populated by a fearful, dependent and excessively conformist middle class, which betrays 
age-old American ideals like ingenuity, autonomy and en:rgy. In studies and novels, critical outsiders outline different yet lindred dystopian versions of suburbia in which peer pressure sileices all expression of individuality. This tradition still provokes iraginative yet pessimistic characterizations.

This image of herd-like behavior rests in a specific view of consumption, an activity that is traditionally assigned great reevance as part of suburban life and that elicits quite contradictor' opinions. Those who consider consumption as a meaningful ictivity from the angle of both the community and the individual rather than as passive hedonism, tend to paint a quite different vesion of suburbia. Its residents, through their new car or at a neighbrrhood barbecue, express mutual similarities and differences, just lile their favorite style of home decoration may express both nostalįia and amzituón. in, tor instance, Inomas Hine's Populuxe (1986) and Barbara Kelly's Expanding the American Dream (1993) the do-it-yourselfer positively contributes to the design of the suburb. In his own way he acts out his American dream, rather than that he is represented as a conformist bore who epitomizes the loss of traditional American ideals.

Besides individuality and herd instinct, or passivity and activity, destiny and willpower organize difference, especially in histories of suburbia. In one version, for example in Robert Fishman's Bourgeois Utopias (1987), a visionary middle class turns suburbia into a thriving autonomous social unit. In other versions, such as Kenneth Jackson's Crabgrass Frontier (1985), the middle class's power to act is restrained while its self-reliance is questioned. The image of the autonomous middle class as the driving force of history is significantly weakened by, among other things, demographic developments, technological innovations, rivaling interests of all kinds of lobby groups and substantial government support. If, finally, an author proclaims the end of traditional suburbia, in one history most prominently in Bourgeois Utopias - the middle class completely disappears from view as actor, while in another, for example Mike Davis's Ecology of Fear (1998) or Rosalyn Baxandall and Elizabeth Ewen's Picture Windows (2000), a fierce struggle among the progressively more dissimilar residents erupts about the definition of postsuburbia. All actors have their own ideas, strategies, memories and 
expectations. Where one is attracted by promise, someone else leaves because of a perceived threat. Where one sees specific opportunities for improvement, another fears having to make a backward step. Similarly, while newcomers approach the future with a sense of expectation, those living in suburbia already cast a nostalgic glance backward or seek recourse in rigid zoning or closing their gates out of fear for the outside world.

The fact that suburban themes and motifs tend to recur, then, does not imply the absence of a rich and diverse offering of suburban images and narratives. Despite several patterns and continuities, various different and competing representations of suburbs and their middle class populations can be found in fiction as well as in social science and humanities studies. Literary narratives are often assumed to enrich the world of representation, in particular regarding time. Novels and stories are expected to add new images of suburbia, present alternatives for dominant images and undermine stereotypes. This dissertation does not so much focus on a comparison of literary and academic representations of suburbia in general, but on confrontations between individual stories, as well as between these stories and various scholarly arguments. This approach underscores that fact and fiction, transparency and ambiguity, and argument and story function as relative categories instead of as binary contrasts.

Some social science studies on suburbia explicitly claim to present ideal-types of suburbanites, rather than actual residents. Even though the characters that populate these studies are not true-tolife, some of these studies nevertheless come across as realistic. This is a direct effect of the deployment of narrative techniques and stylistic strategies that we rather associate with fiction than with science. In William Dobriner's Class in Suburbia (1963), for example, the models and types presented have an individual history and a voice and language of their own. Moreover, the strategy of focalization is used to provide a 'fictional sociological impression', which gives readers a sense that they can witness what actually takes place in Levittown. Conversely, the narrator in John Keats's The Crack in the Picture Window (1956) explains that the site of his story about John en Mary Drone, Rolling Knolls, does not exist, but that it is neverthe- 
less based on facts. The story about this unhappy couple is embedded in a vehement argument against suburbia. The narrator relies on a host of experts to underscore the dreadfulness of suburban living, as embodied by the Drones.

David Karp's Leave Me Alone (1957) is a novel, but in this case, too, narrative and argument are hard to separate. The story about suburbanite Arthur Douglas is basically entwined with a sociological study, which is not carried out by a real expert, as in Keats's story, but by professor Cameron, who inhabits the novel's fictional world. His argument hardly differs, though, from that of the sociological commentaries by influential critics like $\mathrm{C}$. Wright Mills, William $\mathrm{H}$. Whyte and David Riesman. The novel's readers are enticed to identify with protagonist Arthur Douglas, but increasingly they find that it is not he who is central but his fellow suburbanites with whom he is at odds. As illustration of Cameron's sociological model, they are exposed as incarnations of Little Man, Organization Man and the other-directed.

Although most studies and novels on suburban life are populated by quite uncertain, hesitant suburbanites, variations on this pattern are found as well. Textual comparison reveals in fact that minor differences in the various forms of depiction may have substantial consequences for the ways in which relationships between the suburb as site and the temporal orientation and identity of its residents are evoked. Therefore, detailed mapping of how suburbs and their residents are represented should go hand in hand with careful analysis of how these representations are constructed and what they mean. In cultural analysis the how and what should always be considered in tandem.

John Updike's novels Rabbit, Run (1960) and Couples(1968) display similarities with many major social science commentaries on suburban life. These novels' protagonists, Harry Angstrom and Piet Hanema, respectively, can be seen as failures in terms of their autonomy, initiative, vision and power to act. Moreover, if suburban life expresses the ideal image of both nostalgia and ambition, of a sense of retrospection and anticipation, Harry's lower-middle-class suburb Mt. Judge and Piet's upper-middle-class exurb Tarbox are all but characteristic. Despite these similarities, there are revealing dif- 
ferences as well. In a so-called 'chronotopic' reading, aimed at how in and around specific spaces identity and temporal orientation are expressed, they come to the fore.

Rabbit, Run presents Harry's excessive nostalgia and lack of future vision as urgent problems. As is common in the life of fictional suburbanites, Harry's life is dominated by a feeling of oppression, which in his case is organized around an endless series of everyday problems. In a narrative that is structured as a downward spiral he gradually turns inward. He goes around in increasingly smaller circles and spaces. A prisoner of his diminishing horizon, Harry sees no opportunity to pause for a moment and reflect on the mess he made of his life. If studies like Riesman's The Lonely Crowd (1950) articulate an explicit touchstone for criticism of suburbia, Rabbit, Run formulates such critique only implicitly and, moreover, in a non-judgmental way. Harry may be a coward and self-centered, it is nevertheless possible for readers to empathize with his doubts and his disorientation because of an understanding of his circumstances. In contrast to, for instance, the sarcasm in Richard Yates's novel Revolutionary Road (1961), the tone of Updike's novel is primarily marked by compassion.

Like Rabbit, Run, the later novel Couples strikes various chords. It is situated at the intersection of the realist, the symbolic and the burlesque, which results in an intriguing combination of venom, awe, humor and compassion. As opposed to the former novel, Couples judges the world it evokes explicitly. As the characters' interior monologues, dialogues and conduct suggest, they do not hide their aversion of suburban life, nor does the narrator refrain from voicing his opinions. If Piet Hanema still enjoys some sympathy, his circle of friends is sharply criticized. At parties and in their private dwellings the couples look for excitement and variation without endangering the status quo. Yet in isolation, their hedonist lives become increasingly oppressive. The novel represents the couples' cyclical everyday life as failed escapism and their involvement in local politics as a form of action that they quickly abandon after the arrival of a younger generation of suburbanites with their new prefab neighborhoods.

Couples links up an explicitly culture-critical diagnosis - as also found in studies like Richard Sennett's The Uses of Disorder (1970), 
Christopher Lasch's The Culture of Narcissism (1978), and Dutch philogpher René Boomkens's De angstmachine (1996) and Een drempelwerld (1998) - with what it means for the couples involved to see thir ideals evaporate and their desires frustrated. Thus the basic argment of Couples is not necessarily more complex than that of socal science, as suggested, for example, by the split between complx literary art and schematic social science in Elizabeth Long's he American Dream and the Popular Novel (1985). However, the novel des combine a variety of views into a single whole in which mutual dfferences and tensions between the characters are not reduced ti a single perspective but remain visible. Moreover, the novel invies readers to identify with divergent characters and various, perhps contradictory, views and arguments, while also holding up a mirpr. By being convincing, absorbing and confronting, Couples challenę us to reconsider how we feel and think. Like many social science arguments, its basic structure rests in several familiar elements of the suburban imagination, such as the paradisiacal myth and the pastoral, while it is organized around clichés, such as suburban adultery; yet it nevertheless succeeds in involving us in subtle ways. It does not achieve this effect by aggressively countering clichés or attacking standard assumptions. Instead, it fully exploits the space of the literary novel: by presenting thoughts, feelings and behaviors as an integral part of a simultaneously understandable, appealing, despicable, commendable and preposterous lifestyle.

Where Updike's novels basically respect the boundaries of genre, Douglas Coupland's Generation X (1991) allows space for strange new elements. This book's main plot, addressing the generation of people in their late twenties for whom the gates of suburbia proved to be locked in the early 1990s, is complemented by an explanatory and critical ensemble of statements, cartoons, neologisms and aphorisms in the marginal space of its pages, while the novel's appendix provides figures and statistics from official sources in support of its main concern. These marginal comments and the numbers evoke developments in several contexts. Thus readers can understand the problems of protagonists Andy, Dag and Claire in the context of overconsumption and environmental pollution, family issues and the fading middle class - concerns that were earlier represented in 
stories and novels of authors like Don DeLillo, Raymond Carver, Bret Easton Ellis and John Updike. But if we are to understand the downward mobility of Coupland's three protagonists as well, we have to consider relevant humanities and social science studies, such as Barbara Ehrenreich's Fear of Falling (1989) and Katherine Newman's Falling from Grace (1988) and Declining Fortunes (1993). Together, these textual traditions constitute the world in which the three friends are lost and in which they try to reorient themselves in new ways.

Because the novel's main narrative, the marginal lexicon and the appendix mutually refer to each other and are to be understood in combination with each other, a closed-off worldview gradually emerges in which it becomes clear why these three young members of the middle class are hiding in Palm Springs, on the edge of California's Mojave desert. By the early 1990s, many of America's social promises have lost their validity or are no longer available to most, which forces the three friends to fashion a future perspective of their own. In this respect it becomes understandable why it is not easy, even for those in society's periphery, to escape from the middle class frame that disappointed them. Dominant cultural expectations are hard to evade in particular. Gradually, the three manage to conceptualize a future by looking backward rather than forward. Andy and his friends long for a future from the past, one with which their parents grew up and that proved unattainable for Generation $\mathrm{X}$ members.

The silence and withdrawal of the protagonists of Generation $X$ does not mean they are written out of the story. On the contrary, Coupland's novel shows which considerations and activities precisely become possible in the margin. Peripheral Palm Springs is the story's central chronotope. It constitutes an appropriate place for temporal reorientation and allows Andy, Dag and Claire to rediscover a sense of control and authority. No matter how preliminary and hesitant, at the edge of the desert they succeed in making a step forward by talking to each other and doing things, especially telling each other stories. No matter how unpretentiously, their whispering and exploring becomes audible and visible in Coupland's novel. Thus Generation $X$ offers an alternative for the disappearing act in Fishman's Bourgeois Utopias and adds a specific voice and a mode of 
action to the pushing and shoving and calling in, for instance, tob Kling,Spencer Olin and Mark Poster's Postsuburban California (199).

Finally, a most different (post)suburban California takes shapc in Coupland's 'Brentwood Notebook'(1996). In megalopolis Los Anyeles it identifies a fascinating suburban island that in various guies explores issues of place, time and identity. Prosperous Brentwool is represented as a self-contained, unsociable non-place where the orly communal activity is protection against outside influences. Obsessively, the neighborhood guards its borders - against chaoticaly expanding and unpredictable L.A., against attention from the meia and especially against the disadvantaged Other. At all cost, Brettwood's residents try to secure what they have. The neighborhord, suppressing both its past and its future, is only interested in cefenuhing the status quo ot the present, something that takes its toll and is increasingly difficult to realize amidst L.A.'s metropolitan dynamic.

'Brentwood Notebook' is hardly a traditional portrait. It brings to the fore what in the representation of suburbia generally remains hidden. It calls attention not only to what it represents, but also to what is needed to do so. It is not very useful to ask whether Coupland's notebook provides an accurate representation of Brentwood, but it is essential to ask how, exactly, it represents. The article gives one the impression of being a report of a visit to the neighborhood, but it invokes much more than just on-the-spot observations. With the help of classical narratives about suburbia, the author depicts Brentwood as both a utopian and dystopian suburb. At various moments and in various ways its very existence is put in doubt, and the question is raised whether it - in its delimited space in its isolated present - is either a dream come true or a nightmare.

Much in Coupland's portrayal of Brentwood is turned upside down. He draws on archival materials, he uses ads and he quotes from newspapers, magazines, autobiographies, a novel and a social science study. All but hiding the diversity of his sources in a fluent or seemingly transparent narrative, the notebook approach remains visible throughout, including the amount of work that went into portraying just a single suburb. The 'finished' notebook cuts across genres: not strictly belonging to journalism, cultural geography or 
literature, it borrows strategies from each of these domains. Various genre conventions are pitted against each other in playful ways. Certainly, this challenges readers' expectations and forces readers to remain active and attentive. While merely appearing to describe a suburban reality, the notebook simultaneously argues for a specific interpretation of this reality as well as evokes a specific world. If it is viewed as a report of a visit of a suburban neighborhood, it becomes dear that a common strategy of this genre - giving residents a voice of their own - is entirely ignored. In addition, it argues, seeks to convince, but not through systematic argument as found in studies from cultural geography or sociology. As literary work, finally, the notebook evokes an ambiguous, unsettling world. Yet, although this particular tension is found in novels on suburbia like John Cheever's Bullet Park (1967), Gloria Naylor's Linden Hills (1985) and T. Coraghessan Boyle's The Tortilla Curtain (1995), Coupland's text has no story in which we get to know specific characters. Detachment undermines identification, just like fascination disrupts analysis and the author's involvement the suggestion of objectivity. As multifaceted representation of a specific suburb, Coupland's piece is a valuable contribution to the overall representation of suburbia. Perhaps only a confusing portrait like that of Brentwood can serve us as a reminder of both the lively presence and the immanent demise of the suburban dream at the end of the twentieth century.

Although the one-sided, negative representation of suburbia is certainly persistent, it is not unassailable. By paying attention to the spatial representation of time it becomes clear that familiar and even dominant images are subject to reinterpretation, and although the same images continue to recur, there are also competing and sometimes surprising representations of suburbia. The problem is not the suburban myth itself, but the thinking in terms of myth. The latter suggests a negative portrayal of the suburb that is too simple. It hides the crucial link between suburb and middle class from view and, furthermore, does not even prove to be effective. After all, this myth is still regularly invoked, notwithstanding the fifty years of criticism with which it has met.

In suburban studies the suburban myth is a mandatory hurdle, it seems. Critical reflection on suburban life and issues starts in this 
very myth, even with those who oppose it. This may certainly contribute to a shared sense of professionalism or to a legitimizi 1 g of one's academic discipline vis-à-vis other disciplines and the ourside world. Yet the price to be paid is high. Three risks should be nentioned in particular. Those who target the suburban myth elim nate a straw man at best; they run the risk of remaining blind to the ictu- $_{\text {- }}$ al variation of images in social science and humanities studits, as well as in literary stories; and they tend to be oblivious to oppertunities for reflecting on the kind of social and cultural critique $\mathrm{tt}_{\mathrm{at}}$ is embedded in attacks on suburbia.

This study contends that, rather than starting from the suburban myth, we should devote attention to a complex system of d vergent notions - linked to each other, forged together and contrastedthat are associated with suburbia. Thus space is generated for adiscussion that may sover much more thar the single issue of whether suburban life is accurately depicted or not. If the focus is on the suburb, then the middle class is at issue as well; if the focus is on the middle class, then consumption and do-it-yourself activities, initiative and anticipation, conservatism and nostalgia, mobility and ambition are also at issue. It is clear, moreover, that the images of place and time in suburbia's imagined geography are at stake in debates that are not just about arguments but also about views, opinions, emotions, and evaluations. At what point does uniformity turn into monotony, community sense into conformism, nostalgia into paralysis, peacefulness into apathy, autonomy into egotism, ambition into status anxiety, and privacy into isolation? Regardless of the question's formulation, the 'facts' do not answer it. On the contrary, depending on the answer, an array of 'facts' gets presented to us.

In this dissertation the suburban middle class is center-stage. Based on this research, various roads can be taken to further elucidate the various forms of social and cultural critique that are enwrapped in representations of suburbia. For example, by focusing more specifically on the middle class, issues of gender or ethnicity can be developed in more detail. Attention for basic concepts and grand narratives may prompt one to explore issues like progress, the liberation of the middle class, the democratization of comfortable living, and 
the myth of the westward movement as one from past to future. These concerns are not only relevant when it comes to differences between the American east and west coasts, but also in light of the frequent comparison between suburbia in the new world and the various other concepts and forms of dwelling - country estates, garden cities, centers of suburban development, Vinex locations and polycentric Delta metropolis - in the old world. 


\section{Curriculum vitae}

David Hamers werd geboren op 13 juni 1971 in Tilburg. Op jonge leeftijd verhuisde hij naar Bladel, waar hij in 1989 aan het Pius $\mathrm{x}$ College zijn vwo-diploma behaalde. Vanaf 1989 studeerde hij aan de Universiteit Maastricht bedrijfseconomie, wat hij vanaf 1991 combineerde met de nieuwe opleiding cultuur-en wetenschapsstudies. In 1995 studeerde hij af als bedrijfseconoom, in 1996 behaalde hij cum laude het doctoraaldiploma cultuur- en wetenschapsstudies. Naast en na zijn studie werkte hij enige tijd als lid van de Studium Generale-redactie aan lezingen, debatten en talkshows en was hij medeoprichter en redacteur van het tijdschrift SKIN. In januari 1997 werd hij als assistent in opleiding aangesteld aan de Faculteit der Cultuurwetenschappen van de Universiteit Maastricht (capaciteitsgroep Wijsbegeerte) en nam hij deel aan de aio-opleiding van de onderzoekschool Wetenschap, Technologie en Moderne Cultuur (wrMc). Van 2000 tot 2002 combineerde hij het schrijven van zijn proefschrift met een docentschap bij de capaciteitsgroep Letteren \& Kunst. Daarnaast schreef hij artikelen over buitenwijken, identiteit en de grenzen tussen wetenschap en literatuur voor onder meer Kennis en Methode (inmiddels Krisis: tijdschrift voor empirische filosofie), Psychologic en Maatschappij, De Gids en Environment and Planning A en recenseerde hij voor diverse tijdschriften vakliteratuur. Hij voltooide zijn promoticonderzoek in februari 2003 . Momenteel maakt hij deel uit van het Atelier voor Ontwerp en Onderzoek van het Ruimtelijk Planbureau in Den Haag, waar hij onderzoek verricht naar stedelijke rafelranden en rommelzones tussen stad en platteland. 

Fenglocednicuwe srijstande woning in een keurigestran, de krant met een boog in hel voortuintic. $\mathbf{~} /$ ruim siffig jatar lins dere Imerikianse droom in suburbii onder w ür Viet alleen in films

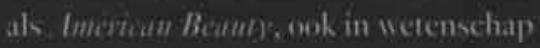
en literatuur moet de buitenmijh het relkens weer ontgeklen.

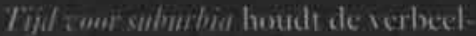
ding san de Imerikamse buiten with en haar middenklasse fegen het fiehu. Hoc iteten stereos pen ons steeds opnieun te rerleiden: / $\mathrm{ijin}$ er subticterelocelden on verhalen in somloop? Wh mocten at in

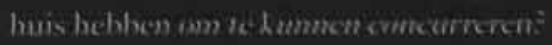
Oin waten als deze re beamı worden.

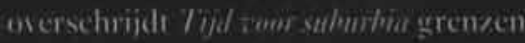
tussen erschillende onderzocksdisciplines en tussen inetenschapen literittuur- Bonendien staat niet zoals gebruihelifh ruime centraal, maar tiid. Gant het om de middenklasses dain draitit het vict allecen om het gexin rond ale barbecue in deachtertuin, malar wooral ook om behoudzucht en nostalesc, mohiliteir en :mbitic:

Vier alleen in de Verenigde staten, ook in Vederland staiat er meer op het spel dian rijen identicke huizen en mid=

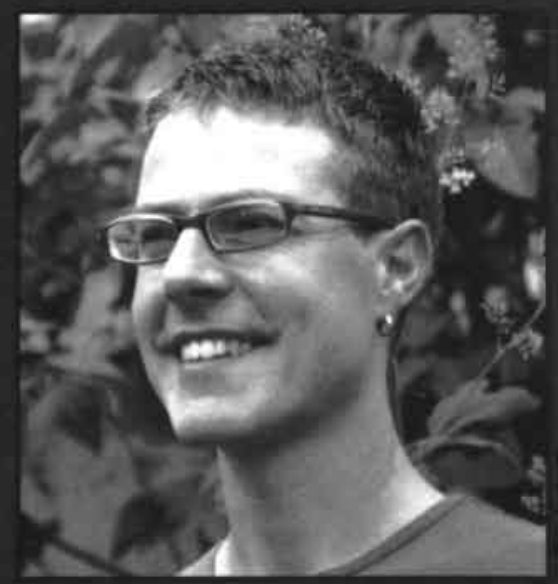

denklasseatuto's. Discussies dic in lmerika al decennialing worden gesoerd, bepalen meeren meer ooh hier de agenda-denk an he fidle debat over de lines-Minh. Kennis s.m de striid om de Imerikaanse butitenu iik kan helpen argumenten, meningen en emotics liver tc begriipen.

David I lamers $(1971)$ is econoom cu cultuurivetensehapper. Dit onderzack natr de rerhedding im suburbia verrichte hiij ande laculecit der Cuhnurrietenschappen sum de L nisersiteil Vlastricht. Over buitenwijken, literature en wetenselap publiceerde hij in himen-en buitenlandse tojelschriften. Nemented is hij als onderhocker werkyaam bit het Ruimtclik. Phanburcau in

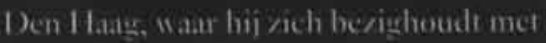
de ratelramelen ran de stakl.

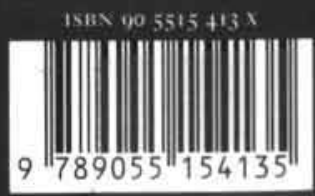

